


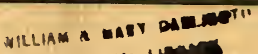

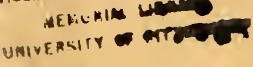

UNIVERSITY OF PITTSBURGH

Dar.

(a)
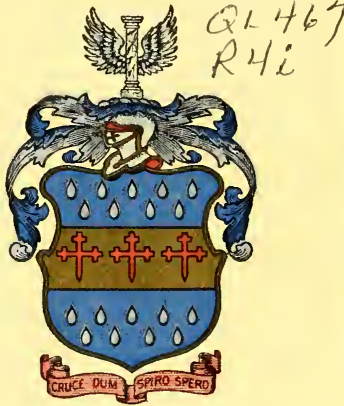

Darlington Memorial Library 






\title{
$2819-56$
}

PUBLISHED UNDER THE SUPERINTENDENCE OF THE SOCIETY FOR THE DIFEUSION OF USEFUL KNOWLEDGE.

\author{
T H E L I B R A R Y
}

or

\section{ENTERTAINING KNOWLEDGE.}

INSECT ARCHITECTURE. 




\section{CONTENTS.}

\section{CHAPTER I.}

INTRODECTION.

\section{Instruction derivable from common things}

Extraordinary numbers and varieties of lusects

Can he studied in every situation

Anecdotes

Cabinets useful but not indispensahle ${ }^{\circ} \cdot{ }^{*} \quad 6$

Study of Inepets does not narrow the mind . $\quad 7$

Injuries and Benefits caused by Insects . . 9

Use of names in Natural History . . . . 12

Study of Insects fascinating to youth . . . 13

Anrcdote of a little girl.$\quad$. $\quad . \quad 14$

.15

$\begin{array}{lll}\text { Varieties in the economy of lnsects. } & * & 16 \\ \text { States of Insects } & & 17\end{array}$

lnsects produced from eggs . $\quad$. . . ib.

Larva, Caterpillar, Gruh, Maggot • . 20

Pupa, Chrysalis, Aurelia, N simph . . . 21

Imago, perlect Insect . $\quad$ • $\quad$ - 22

CHAPTER II.

Structures for protecting Eggs $\quad$ • $\quad$ - 23

Eggs of Insects can bear great degrees of heat and cold ib.

Bes compared to our mechanics • • - 25

Masou-Wasps
Curious proceedings of one at Lee . . . . . $\quad$ ib.

Her caution outwitted hy a Fly $\quad$. $\quad 28$

Structures of another Mason-W asp . . . 29

- Her storing of live Caterpillars . . . 32

Mason-Bees . • 33

Nest of one on the wall of Greenwich Park . . ih.

Clay-ınine of Mason Bees at Lee . . . 35

Estinate of their labours • . $\quad 37$

Wall-Mason-Bees of France $\quad . \quad$. 38

Proceedings of the two-horned Mason Bee at Lee $\quad 39$

Structures of Mason Beps . . • • 41

m Their restless dispositiou . . . . 42

Mining-Bees . . . . . 43

Their different proceedings in Britain and in France . 44

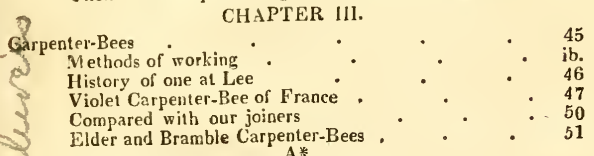


Carpenter-Wavps

Curious cocoon of $\quad . \quad . \quad 53$

Upholsterer-Bees

Poppy-Flower Bee of Largs and of Bercy . . $\quad 5$

Taste of the little arehitects in ornament . 56

Cotton-Gathering Bee . . . . 57

Rose-Leaf-Cntter Bee $\quad$. $\quad$ • 50.59

Her nethod of working . . . . 60

A Decdote of St Francis Xavies . . 63

CHAPTER IV.

Carder-Bees

Method of preparing and conveying their materials 64

Structure of their nests

Lapidary-Bees

lertinacity in defending their nest

Humble-Bres

Siructure of their nests

Social-1T asps

Nest founded hy a single female

Compared with the Burrowing-Owl

Materials rasped off from wood

Different opinions of Naturalists

Paper made by Wasps

Structure of the nest

Extraordinary number of celts

Hoinet's nest

Tree. W asps' nests in Ayrshire

Rose shaped Wasps' nest

Vertical Wasps' nest

Wasp-paper compared with ours

Card making Wasp of Cayentse

\section{CHAPTER V.}

Arehitecture of the Hive-Bee

Nurse-Bees and $\mathrm{Wax}-W$ orkers

Preparation of wax

int by the Abbe la Pluche.

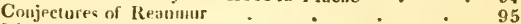

Di:covery of John Hunter . • • • 96

Experiments of M. Huber . . . ${ }^{\circ} 97$

Singular fac's by Mr Wiston . . . 100

Propolis

Dissections by Madlle Jurine and M. Latreille $\quad 102$

Discovery by Huber ${ }^{\circ} \quad \cdot \quad 106$

..$\quad$ ib.

Mr'T. A liniglit's observations • • • 103

B ssket for carrying on the thighs of Bees - . 110

Building of the cells

Process of loading.$\quad 111$

Division of labour ${ }^{\circ} \quad \cdot \quad \cdot \quad \cdot$ ib. 


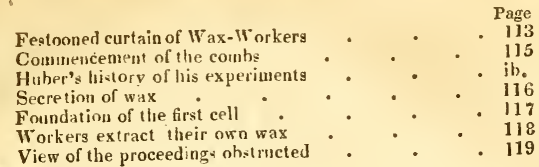

CHAPTER VI.

Form of the cells

Mathematical problem solverl by Bees

Calculated by Maraldi and Kœuig

Reasons for the form of the cells

Referred to the form of the Bee

Experiments of Huher

Cells commenced in the fomndation-wall

Deepening of the cells

Polishing hy Nurse Bees

Distance of the combs from each other

Dr Barclay's discovery

Irregularities in their workmanship

Anecdote from Dr Bevan

Similar arecdote from Huber

Symmetry in the architecture of Bees explained

Curved combs

Fixperiments of Huber .

Size of male cells

Cells enlarged when honey is plentiful

The finishing of the cells .

Varnished with propolis

Strengthened with pissoceros

Discovered by Huber

Cells strengthened by the Bee-grubs

Difficulties explained

Mistake of an American writer $. . \quad . \quad . \quad 141$

Curious experiment of Huber . . . . ib.

Wild-Honey-Bees

Wild-Bees of America, Ireland, Palestine . . 143

Honey-guide of Africa $\quad$. $\quad . \quad$. 145

Bee-hunting in America

146

CHAPTER VII.

Carpentry of Tree hoppers (Cicad $x$ )

Mistaken for Grass-hoppers

Singular cutting instrument of the Tree-hopper $\quad 148$

Double files of . $\quad$ • $\quad 150$

Their Nests . . . . . . 151

Saw.Flies

Flies ${ }^{\circ}, 152$

- Their ovipositor . . . . . 153

Structure of $\quad . \quad . \quad . \quad . \quad . \quad 154$

Comb-toothed rasp, and saw . _ . . 156

Grooves cut by it in the rose-tree. . . 158 


\section{CHAPTER VIII.}

Leaf-Rolling-Caterpillars

Lilac-Leaf Roller

O.sk-Leaf-Roller

Roze Leaf Roller

Nettle-Leaf-Roller

Method of proceeding

Probuble miatake concerniu

Sorrel-Leaf-Roller

Admirable and painterl Lady, Butterflies .

Malluw Butteifly of France

Willow-l, asf-Bundler

Neat of Ziczac Cdterpillar

Nest of Glauville-Fritillary

Experimeit on gregarious Caterpillars by J. R.

Desigu in rolliug leaves

CIIAPTER IX.

Habitations formed of detached leaves

The Pondweed Tent-Maker . . . 177

Chickweed Caterpillar's nest . . . 178

Cypress purge Caterpillar's uest . . 179

lhurability of these structures

180

Compared with our architecture

181

Moss-cell of a Wall Caterpillar

183

Caterpillar of Greenwich l'ark wall

184

CHAPTER X.

Caddis-worms

Leaf and reed nests of

Shell nest of

Stone and saud nests of

Nest bilanced sith straws

Carpenter-Caterpillars

Caterpillar of Goat-Mtotl

Its winter nes

Singular nest of

Nest of the Egeria in a poplar .

Piper-nest of the Puss-Muth

185

ih.

186

187

$1: 8$

189

ib.

190

191

192

193

Jlow it escapes from ite cell .

Purple Capricorn-Buptle. . . . 196

Eark-huilding Caterpillar of the oak

CIIPTIER XI.

Earth. Mason-Caterpillars

Outside walls of their nests

Caterpillar of (ilost Mnth

il).

Fxperiments of Reaumur

Nests of liphemera (irubs

$: 206^{\circ}$

Similar nests in a willow stump . . 207

Nests of the Cicindela-Bectle . . it. 
Structure of the Grub

Page

Formation of its traps

Reflections upon the economy of Nature

210

\section{CHAPTER XII.}

Clothes-Moth Caterpillars .

Varieties in the species

Meitunds of destroying

Mode of buildiug

Experiments upon

Migrations of .

Tent-Maki ig Caterpillars

Mode of constructing these ${ }^{\circ}$. $\quad . \quad 224$

Experiments upon

Tent upon a Nettle-leaf

Stone-Mason Caterpillars

'Their singular proceediugs

Colony of, at Blacklseath

Fonndation of their Teots

Muif aba ped 'Tents

An attempted robbery

Leaf-Mining Caterpillars

On the leaf of the Montlily Rose-tree

On the leaf of tive Bramble

On the leaf of the Prinrose

Vine-leaf Miner

Ou the leaf of the Alder

Social Leaf-Winers

Bark-mining Caterpillars

\section{CHAPTER XII.}

Structures of Crickets

House.Cricket

The Mole-Cricket

The Field-Cricket

Beetles

Mode of depositing eggs

The Bursing-Beetle

The Dang-Beelle .

Its cleauliness.

The Rose-Chafer

The Tumble-dung Beetle

The Nechlace-Beetle

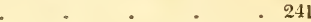

ib.

242

244

- 246

247

ib.

249

- 250

251

- ih.

253

CHAPTER XIV.

A rchitecture of Ants

Their genuine history begun by Gould

- 254

Mason-ants

Structuree of Turf-Ants

Winter nest of Yellow-Ants

Sort of earth employed in building

ib.

- 255

ih.

Proceedings of the Brown-Ant .

- 256

- 258 


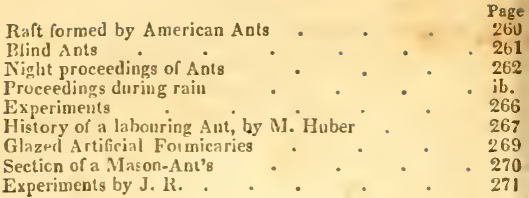

CHAPTER XV.

Structures of the Wood-Ants, or Pisnires

272

Materials enıployed

ib.

Coping of their nest . . . . 273

Interior structure . . . . 275

Glazed Formicary for experiments . $\quad 276$

Their proceedinge at uight-fall . . . 277

Carpenter-Ants

Eininets, or Jet Ants

Their galleries in Trees

ib.

Extreniely populous colony at Brockley

Dusky-Ants

Foreign $\Lambda \mathrm{nts}$

Sugar-Ants of the West-Indies

$\geq 81$

282

283

284

286

\section{CHAPTER XVI.}

Structures of White-Ants, or Termites

Their extraordinary comparative height

288

Their mising operations

ib.

289

The Warrior (Termes bellicosus) .

291

L'sed as delicate foorl

Conmencenient of their nests

29:

Royal cluaniber

ib.

295

Nurseries . . 296

Galleries and covert ways . . . . 298

Turret-huilding White-Ants. . 301

Singular form of their nests . $\quad . \quad 302$

White-Ants of trees and timber . . . . ih.

Death-Watch

\section{CISPTER XVI.}

Spiuning-Caterpillars

Manifuld advantages of spinning

306

$\begin{array}{ll}\text { Structure of theit legs and feet } & 307\end{array}$

Side spiracle.e for breathing . . 308

Internal struclure . . $\quad 309$

Stumctume of the silk-tuhe . . 310

Mode of spinnirg ch scribed by Ia Pluclue . - it. 
Their transformations . 314

$\mathrm{H}$ uw they make their exit from the cocnons - 315

Parts used in nur manufactures . $\quad 317$

History of the introluction of silk . 318

Varieties and species of silk-wormıs . . 320

Einperor-Mnth . . . . ib.

Ingenious contrivance of the cocoon . $\quad 321$

Spinning-Caterpillars continued . . . . 322

Elastic cocoon of Tortrix chlorana . . . ib.

Slender covering of the Gspsey-Moth . . 323

Cocoon of the Cream-apot Tiger-moth . 324

Experiment with the Dock. Weevil . $3: 5$

Nest of Puss Moth, with cocoons of Ichneumons 326

$\begin{array}{ll}\text { Cocoon of the Horned Mason-Bee } & 327\end{array}$

Experiment with Erioguster lanestris . ib.

Social Spinning-Caterpillars . . $\quad 329$

Winter nest of the Brown-tail moth . $\quad 330$

Winter nests of the Golden-tail Moth . 331

Pendulous leaf nests, from Bonnet . . . $\quad 332$

Nest of Processionary Caterpillars . . 334

\section{CHAPTER XVIII.}

Structures of Spiders

Spiders not properly insects, and why

Apparatus for spinning

Extraordinary number of spinnerules

Attachment of the end of a thread . $\quad 339$

Shooting of the lines of Spiders

1. Opinions of Redi, Swammerdam, and Kirby . 340

2. - Lister, Kirhy, and White - . 342

3. — La Pluche and Bingley - 344

4. - D'lsjonval, Murray, and Bowman . ib.

5. Experiments of $\mathrm{Mr}$ Blackwall . 346

His account of the ascent of gossamer . 348

6. Experiments by J. R. . . $\quad 350$

Thread supposed to go off double . $\quad 351$

Subsequent experiments . . . $\quad 352$

Nests, Webs, and Nets of Spiders . • . • 354

Elastic satin nest of a Spider . . . ib.

Evelyn's account of lumting Spiders . $\quad 355$

Labyrinthic Spider's nest • • $\quad 356$

Erroneous account of the House Spider . $\quad 3.77$

Geometric spiders . . $\quad 358$

Mason-Spiders . $\quad . \quad 360$

Ingenious door with a hinge $\quad \cdot \quad 362$

Nest from the West Indies, with spring hinge . ib.

Raft-building Spider 
Diving Water-Spider

Observations of M. Clerck

Cleanliness of Spiders

Structure of their claws

Fanciful account of them patting their mebs

Proceedings of a Spider in a sleam-boat

CHAPTER XIX.

Structures of Gall-fies

Berry-gall of the oak-leaf, \&c.

Ingenious mechanism of the ovipositor

Opinions of Naturalists as to the cause of Galls . 373

Bedeguar of the rose

Artichoke-gall of the oak .

Leafy-gall of Dyer's broum

Rose willow

Rose-hawthorn

Woolly-gall of the oak.

Experinents with the flies

Oals-apples

Root.galls of the oak

IVoüdy-gall of the wi!low

Weevil-Gall

Cat: currant-galls

IVevil.gall of the hawthorn

Aubury on the reots of cabbages, \&c.

Semi-falls of A phides

Mountain-asb leaf-galls

Poplar semi-galls of the cotiony aphis

Leaf-rolling Aphides

Leaf of the currant-brith this altered

Pseudo-Galls

Shoot of the lime-tree thus convoluted

Pseudo-gall of the bramble

ib.

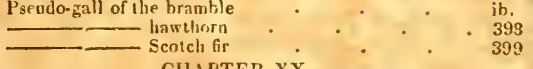

CHAPTER XX.

Animal-Galls

. . 401

Enthusiasm of M. Reaumur for study . . 402

Ovipositor of Breezf-Flies . . . . 403

Opinion of Mr Bracey Clark on its use . . 404

Effects produced by the fly upon cattle . . 405

Uhservations of Iinnaus on the Reiu-ceer Breeze-Fly 406

Opinion of Kirby and Spence . . . 407

Observations of Mr B. Clark . . . 403

liatcling of the egg . . . 4 4 410

Bumpa, or wurbles, thence produced . . 412

Communication of the grub with the air . . 413

Final cause of these bumps.$*^{*} \cdot 414$

The Zinub (Breeze-fly !) of Afri:a . . . 415

Human Breese-fly . . . ib.

Grub paravite in the Gardeu-Snail . . . . 416 
Chafter I.

I NTRODUCTION.

Ir can never be too strongly impressed upon a mind anxious for the acquisition of knowledge, that the commonest things by which we are surrounded are deserving of minute and careful attention. The most profound investigations of Philosophy are necessarily connected with the ordinary circumstances of our being, and of the world in which our every-day life is spent. With regard to our own existence, the pulsation of the heart, the act of respiration, the voluntary movement of our limbs, the condition of sleep, are among the most ordinary operations of our nature; and yet how long were the wisest of men struggling with dark and bewildering speculations before they could offer any thing like a satisfactory solution of these phenomena, and how far are ae still from an accurate and complete knowledge of them! The science of Meteorology, which attempts to explain to us the philosophy of matters constantly before our eyes, as dew, mist, and rain, is dependent for its illustrations upon a knowledge of the most complicated facts, such as the influence of heat and electricity upon the air; and that knowledge is at present so imperfect, that even these common occurrences of the weather, which Vol. IV. 
men have been observing and reasoning upon for ages, are by no means satisfactorily explained, or reduced to the precision that every science should aspire to. Yet, however difficult it may be entirely to comprehend the phenomena we daily witness, every thing in nature is full of instruction. Thus the humblest flower of the field, although, to one whose curiosity has not been excited, and whose understanding has, therefore, remained uninformed, it may appear worthless and contemptible, is valuable to the botanist, not only with regard to its place in the arrangement of this portion of the Creator's works, but as it leads his mind forward to the consideration. of those beautiful provisions for the support of vegetable life, which it is the part of the physiologist to study and admire.

This train of reasoning is peculiarly applicable to the economy of insects. They constitute a very large and interesting part of the animal kingdom. They are everywhere about us. The spider weaves his curious web in our houses; the caterpillar constructs his silken cell in our gardens; the wasp that hovers over our food has a nest not far removed from us, which she has assisted to build with the nicest art; the beetle that crawls across our path is also an ingenious and laborious mechanic, and has some curious instinets to exhibit to those who will feel an interest in watching his movements; and the moth that eats into our clothes has something to plead for our pity, for he came, like us, naked into the world, and he has destroyed our garments, not in malice or wantonness, but that he may clothe himself with the same wool which we have stripped from the sheep. An observation of the habits of these little creatures is full of valuable lessons, which the abundance of the examples has no tendency to diminish. The more such observations are multiplied, the more are we led forward to the 
freshest and the most delightful parts of knowledge; the more do we learn to estimate rightly the extraordinary provisions and most abundant resources of a creative Providence; and the better do we appreciate our own relations with all the infinite varieties of Nature, and our dependence, in common with the ephemeron that flutters its little hour in the summer sun, upon that Being in whose scheme of existence the humblest as well as the highest creature has its destined purposes. "If you speak of a stone," says St Basil, one of the Fathers of the Church, " if you speak of a fly, a gnat, or a bee, your conversation will be a sort of demonstration of His power whose hand formed them; for the wisdom of the workman is commonly perceived in that which is of little size. He who has stretched out the heavens, and dug up the bottom of the sea, is also $\mathrm{He}$ who has pierced a passage through the sting of the bee for the ejection of its poison."

If it be granted that making discoveries is one of the most satisfactory of human pleasures, then we may without hesitation affirm, that the study of insects is one of the most delightful branches of natural his tory, for it affords peculiar facilities for its pursuit. These facilities are found in the almost inexhaustible variety which insects present to the entomological observer. As a proof of the extraordinary number of insects within a limited field of observation, $\mathrm{Mr}$ Stephens informs us, that in the short space of forty days, between the middle of June and the beginning of August, he found, in the vicinity of Ripley, specimens of above two thousand four hundred species of insects, exclusive of caterpillars and grubs,-a number amounting to nearly a fourth of the insects ascertained to be indigenous. He further tells us, that among these specimens, although the ground had, in former seasons, been frequently explored, 
there were about one hundred species altogether new, and not before in any collection which he had inspected, including several new genera; while many insects reputed scarce were in considerable plenty.* The localities of insects are, to a certain extent, constantly changing; and thus the study of them has, in this circumstance, as well as in their manifold abundance, a source of perpetual variety. Insects, also, which are plentiful one year, frequently become scarce, or disappear altogether, the next-a fact strikingly illustrated by the unconmon abundance, in 1826 and 1827, of the seven-spot lady-bird (Coccinella septempunctata), in the vicinity of London, though during the two succeeding summers this insect was comparatively scarce, while the small twospot lady-bird (Coccinella bipunctata) was plentiful.

There is, perhaps, no situation in which the lover of nature and the observer of animal life may not find opportunities for increasing his store of facts. It is told of a state prisoner under a cruel and rigorous despotism, that when he was excluded from all commerce with mankind, and was shut out from books, he took an interest and fornd consolation in the risits of a spider; and there is no improbability in the story. The operations of that persecuted creature are among the most extraordinary exhibitions of mechanical ingenuity; and a daily wateling of the workings of its instinct would beget admiration in a rightly constituted mind. The poor prisoner had abundant leisure for the speculations in which the spider's web would enchain his understanding. We have all of us at one period or other of our lives, been struck with some singular evidence of contrivance in the economy of insects, which we have seen with our

* Stephen's Illustrations, vol. i., p. $i 2$, note. 
own eyes. Want of leisure, and probably want of knowledge, have prevented us from following up the curiosity which for a moment was excited. And yet some such accident has made men Naturalists, in the highest meaning of the term. Bonnet, evidently speaking of himself, says, "I knew a Naturalist, who, when he was seventeen years of age, having heard of the operations of the ant-lion, began by doubting them. He had no rest till he had examined into them; and he verified them, he admired them, he discovered new facts, and soon became the disciple and the friend of the Pliny of France*" (R:aumur.) It is not the happy fortune of many to be able to devote themselves exclusively to the study of nature, unquestionably the most fascinating of human employments; but almost every one may acquire sufficient knowledge to be able to derive a high gratification from beholding the more common operations of animal life. His materials for contemplation are always before him. Some weeks ago we made an excursion to West Wood, near Shooter's Hill, expressly for the purpose of observing the insects we might meet with in the wood; but we had not got far among the bushes, when heavy rain came on. We immediately sought shelter among the boughs of some thick underwood, composed of oak, birch, and aspen; but we could not meet with a single insect, not even a gnat or a fly, sheltered under the leaves. Upon lonking more narrowly, however, into the bushes which protected us, we soon found a variety of interesting objects of study. The oak abounded in galls, several of them quite new to us; while the ieaves of the birch and the aspen exhibited the curious serpentine paths of the minute mining caterpillars. When we had exhausted the narrow field of

* Contemplation de la Nature, part ii, ch. 42.

vol. IV. 
observation immediately around us, we found that we could considerably extend it, by breaking a few of the taller branches near us, and then examining their leaves at leisure. In this manner two hours glided quickly and pleasantly away, by which time the rain had nearly ceased; and though we had been disappointed in our wish to ramble through the wood, we did not return without adding a few interesting facts to our previous knowledge of insect economy.*

It will appear then, from the preceding observations, that cabinets and collections, though undoubtedly of the highest use, are by no means indispensable, as the observer of nature may find inexhaustible subjects of study in every garden and in every hedge. Nature has been profuse enough in affording us materials for observation, when we are prepared to look about us with that keenness of inquiry, which curiosity, the first step in the pursuit of knowledge, will unquestionably give. Nor shall we be disappointed in the gratification which is thus within our reach. Were it no more indeed than a source of agreeable amusement, the study of insects comes strongly recommended to the notice of the well educated. The pleasures of childhood are generally supposed to be more exquisite, and to contain less alloy, than those of riper years; and if so, it must be because then every thing appears new and dressed in fresh beauties: while in manhood, and old age, whatever has frequently recurred begins to wear tice tarnish of decay. The study of nature affords us a succession of "ever new delights," such as charmed us in childhood, when cvery thing had the attractions of novelty and beauty; and thus the mind of the naturalist may have its own fresh and vigorous

* The original observations in this volume which are marked by the initials J. R., are by J. Rennic, A.M., A.L.S., Lee, Kent. 
thoughts, even while the infirmities of age weigh down the body.

It has been objected to the study of insects, as well as to that of Natural History in general, that it tends to withdraw the mind from subjects of higher moment; that it cramps and narrows the range of thought; and that it destroys, or at least weakens, the finer creations of the fancy. Now, we should allow this objection in its fullest extent, and even be disposed to carry it further than is usually done, if the collecting of specimens only, or, as the French expressively call them, chips (échantillons), be called a study. But the mere collector is not, and cannot be, justly considered as a naturalist; and, taking the term naturalist in its enlarged sense, we can adduce some distinguished instances in opposition to the objection. Rousseau, for example, was passionately fond of the Linnæan botany, even to the driest minutiæ of its technicalities; and yet it does not appear to have cramped his mind, or impoverished his imagination. If Rousseau, however, be objected to as an eccentric being, from whose pursuits no fair inference can be drawn, we give the illustrious example of Charles James Fox, and may add the names of our distinguished poets, Goldsmith, Thomson, Gray, and Darwin, who where all enthusiastic naturalists. We wish particularly to insist upon the example of Gray, because he was very partial to the study of insects. It may be new to many of our readers, who are familiar with the Elegy in a Country Church-yard, to be told that its author was at the pains to turn the characteristics of the Linnæan orders of insects into Latin hexameters, the manuscript of which is still preserved in his interleaved copy of the "Systema Naturæ." Further, to use the somewhat exaggerated words of Kirby and Spence, whose work on Entomology is one of the most instructive and pleasing books on 
the science, "Aristotle among the Greeks, and Pliny the Elder among the Romans, may be denominated the fathers of Natural History, as well as the greatest philosophers of their day; yet both these made insects a principal object of their attention: and in more recent times, if we look abroad, what names, greater than those of Redi, Malpighi, Vallisnieri, Swammerdam, Leeuwenhoek, R taumur, Linnæus, De Geer, Bonnet, and the Hubers? and at home, what philosophers have done more honour to their country and to human nature than Ray, Willoughby, Lister, and Derham? Yet all these made the study. of insects one of their most favourite pursuits."

And yet this study has been considered, by those who have superficially examined the subject, as belonging to a small order of minds; and the satire of Pope has been indiscriminately applied to all collectors, while, in truth, it only touches those who mistake the means of knowledge for the end:

" $\mathrm{O}$ ! would the sons of men once think their eyes

And reason given them but to study Flies!

See Nature in some partial, narrow shape,

And let the Author of the whole escape;

Learn but to trifle; or, who most observe,

To wonder at their Maker not to serve." $\dagger$

Thus exclaims the Goddess of Dulness, sweeping into her net all those who study nature in detail. But if the matter were rightly appreciated, it would be evident that no part of the works of the Creator can be without the deepest interest to an inquiring mind; and that a portion of creation, which exhibits such extraordinary manifestations of design as is shewn by insects, must have attractions for the very highest understanding.

An accurate knowledge of the properties of insects

* Introduction to Entomology, vol. i.

+ Dunciad, book ir. 
is of great importance to man, merely with relation to his own comfort and security. The injuries which they inflict upon us are extensive and complicated; and the remedies which we attempt, by the destruction of those creatures, both insects, birds, and quadrupeds, who keep the ravagers in check, are generally aggravations of the evil, because they are directed by an ignorance of the economy of nature. The little knowledge which we have of the modes by which insects may be impeded in their destruction of much that is valuable to us, has probably proceeded from our contempt of their individual insignificance. The security of property has ceased to be endangered by quadrupeds of prey, and yet our gardens are ravaged by aphides and caterpillars. It is somewhat startling to affirm that the condition of the human race is seriously injured by these petty annoyances; but it is perfectly true that the art and industry of man have not yet been able to overcome the collective force, the individual perseverance, and the complicated machinery of destruction which insects employ. A small ant, according to a most careful and phitosophical observer, opposes almost invincible obstacles to the progress of civilization in many parts of the equinoctial zone. These animals devour paper and parchment; they destroy every book and manuscript. Many provinces of Spanish America cannot, in consequence, shew a written document of a hundred years' existence. "What developement," he adds, "can the civilization of a people assume, if there be nothing to connect the present with the past-if the depositories of human knowledge must be constantly renewed-if the monuments of genius and wisdom cannot be transmitted to posterity ?"* Again, there are beetles which deposit their larvæ

* IIumboldt, Vovage, lib. vii., ch. 20. 
in trees, in such formidable numbers, that whole forests perish, beyond the power of remedy. The pines of the Hartz have thus been destroyed to an enormous extent; and in North America, at one place in South Carolina, at least ninety trees in every hundred, upon a tract of two thousand acres, were swept away by a small, black, winged bug. And yet, according to Wilson, the historian of American birds, the people of the United States were in the habit of destroying the red-headed woodpecker, the great enemy of these insects, because he occasionally spoilt an apple.* The same delightful writer, and true naturalist, speaking of the labours of the ivory-billed woodpecker, says, "would it be believed that the larvæ of an insect, or fly, no larger than a grain of rice, should silently, and in one season, destroy some thousand acres of pine trees, many of them from two to three feet in diameter, and a hundred and fifty feet high? in some places the whole woods, as far as you can see around you, are dead, stripped of the bark, their wintry-looking arms and bare trunks bleaching in the sun, and tumbling in ruins before every blast." $†$ The subterraneous larva of a species of beetle (Zabrus gibbus) has often caused a complete failure of the seed-corn, as in the district of Halle in 1812. $\neq$ The corn-weevil, which extracts the flour from grain, leaving the husk behind, will destroy the contents of the largest storehouses in a very short period. The wire-worm, and the turnip-fly, are dreaded by erery farmer. The ravages of the locust are too well known not to be at once recollectcd, as an example of the formidable collective power of the insect race. The white ants of tropical countries sweep away whole villages, with as much certainty as a fire or an inun-

* Amer. Orinth., i., p. 144. + Ib., iii., p. 21. ‡ Blumenbach. 
dation; and ships even have been destroyed by these indefatigable republics. Our own docks and embankments have been threatened by such minute ravagers.

The enormous injuries which insects cause to man may thus be held as one reason for ceasing to consider the study of them as an insignificant pursuit; for a knowledge of their structure, their food, their enemies, and their general habits, may lead, as it often has led, to the means of guarding against their injuries. At the same time we derive from them both direct and indirect benefits. The honey of the bee, the dye of the cochineal, and the web of the silk worm, the advantages of which are obvious, may well be balanced against the destructive propensities of insects which are offensive to man. But a philosophical study of natural history will teach us, that the direct benefits which insects confer upon us are even less important than their general uses in maintaining the economy of the world. The mischiefs which result to us from the rapid increase and the activity of insects, are merely results of the very principle by which they confer upon us numberless indirect advantages. Forests are swept away by minute flies; but the same agencies relieve us from that extreme abundance of vegetable matter, which would render the earth uninhabitable, were this excess not periodically destroyed. In hot countries, the great business of removing corrupt animal matter, which the vulture and the hyæna imperfectly perform, is effected with certainty and speed by the myriads of insects that spring from the eggs deposited in every carcass, by some fly seeking therein the means of life for her progeny. Destruction and reproduction, the great laws of Nature, are carried on very greatly through the instrumentality of insects; and the same princi- 
ple regulates even the increase of particular species of insects themselves. When aphides are so abundant that we know not how to escape their ravages, flocks of lady-birds instantly cover our fields and gardens to destroy them. Such considerations as these are thrown out to shew that the subject of insects has a great philosophical importance-and what portion of the works of Nature has not? The habits of all God's creatures, whether they are noxious, or harmless, or beneficial, are worthy objects of our study. If they affect ourselves, in our health or our possessions, whether for good or for evil, an additional impulse is naturally given to our desire to attain a knowledge of their properties. Such studies form one of the most interesting occupations which can engage a rational and inquisitive mind; and, perhaps, none of the employments of human life are more dignified than the investigation and survey of the workings and the ways of Nature in the minutest of her productions.

The exercise of that habit of observation which can alone make a naturalist- " an out-of-door naturalist," as Daines Barrington called himself-is well calculated to strengthen eren the most practical and merely useful powers of the mind. One of the most valuable mental acquirements is the power of discriminating among things which differ in many minute points, but whose general similarity of appearance usually deceives the common observer into a belief of their identity. Entomology, in this point of view, is a study peculiarly adapted for youth. According to our experience, it is exceedingly difficult for persons arrived at manhood to acquire this power of discrimination; but in early life, a little care on the part of the parent or teacher will render it comparatively easy. In this study the knowledge of things should go along with that of words. "If names perish," says 
Linnæus, " the knowledge of things perishes also;" and without names, how can any one communicate to another the knowledge he has acquired relative to any particular fact, either of physiology, habit, utility, or locality? On the other hand, mere catalogue learning is as much to be rejected as the loose generalizations of the despisers of classification and nomenclature. To name a plant, or an insect, or a bird, or a quadruped rightly, is one step towards an accurate knowledge of it; but it is not the knowledge itself. It is the means, and not the end, in natural history, as in every other science.

If the bias of opening curiosity be properly directed, there is not any branch of natural history so fascinating to youth as the study of insects. It is, indecd, a common practice in many families, to teach children, from the earliest infancy, to treat the greater number of insects as if they were venomous and dangerous, and, of course, meriting to be destroyed, or, at least, avoided with horror. Associations are by this means linked with the very appearance of insects, which become gradually more inveterate with advancing years; provided, as most frequently happens, the same system be persisted in, of avoiding or destroying almost every insect which is unlucky enough to attract observation. How much rational amusement and innocent pleasure is thus thoughtlessly lost ; and how many disagreable feelings are thus created, in the most absurd manner! "In order to shew," says a writer in the Magazine of Natural History, "that the study, or (if the word be disliked) the observation of insects is peculiarly fascinating to children, even in their early infancy, we may refer to what we have seen in the family of a friend, who is partial to this, as well as to all the

* Nomina si pereant, perit et cognitio rerum.

VOL. IV. 
departments of natural history. Our friend's children, a boy and a girl, were taught, from the moment they could distinguish insects, to treat them as objects of interest and curiosity, and not to be afraid even of those which wore the most repulsive appearance. The little girl, for an example, when just beginning to walk alone, encountered one day a large staphylinus (Goërius olens? Stephens; vulgo the devil's coachhorse), which she fearlessly seized, and did not quit her hold, though the insect grasped one of her fingers in his formidable jaws. The mother, who was by, knew enough of the insect to be rather alarmed for the consequences, though she prudently concealed her feelings from the child. She did well; for the insect was not strong enough to break the skin, and the child took no notice of its attempts to bite her finger. A whole series of disagreeable associations with this formidable-looking family of insects was thus averted, at the very moment when a different mode of acting on the part of the mother would have produced the contrary effect. For wiore than two years after this occurrence, the little girl and her brother assisted in adding numerous specimens to their father's collection, without the parents ever having had cause, from any accident, to repent of their employing themselves in this manner. The sequel of the little girl's history strikingly illustrates the position for which we contend. The child happened to be sent to a relative in the country, where she was not long in having carefully instilled into her mind all the usual antipathies against ' everything that creepeth on the earth :' and though she afterwards returned to her paternal home, no persuasion nor remonstrance could ever again persuade her to touch a common bectle, much less a staphylinus, with its tail turned up in a threatening attitude, and its formidable jaws ready extended for attack or defence." 
We do not wish that children should be encouraged to expose themselves to danger, in their encounters with insects. They should be taught to avoid those few which are really noxious-to admire all-to injure none.

The various beauty of insects-their glittering colours, their graceful forms-supplies an inexhaustible source of attraction. Even the most formidable insects, both in appearance and reality, - the dragonfly, which is perfectly harmless to man, and the wasp, whose sting every human being almost instinctly shuns,-are splendid in their appearanbe, and are painted with all the brilliancy of natural hues. It has been remarked, that the plumage of trophical birds is not superior in vivid colouring to what may be observed in the greater number of butterflies and moths.* "See !" exclaims Linnæus, " the barge, elegant painted wings of the butterfly, four in number, covered with delicate feathery scales! With these it sustains itself in the air a whole day, rivalling the flight of birds and the brilliancy of the peacock. Consider this insect through the wonderful progress of its life,-how different is the first period of its being from the second, and both from the parent insect! Its changes are an inexplicable enigma to us : we see a green caterpillar, furnished with sixteen feet, feeding upon the leaves of a plant; this is changed into a chrysalis, smooth, of golden lustre, hanging suspended to a fixed point, without feet, and subsisting without food; this insect again undergoes another transformation, acquires wings, and six feet, and becomes a gay butterfly, sporting in the air, and living by suction upon the honey of plants. What has Nature produced more worthy of our admiration than such an animal coming upon the stage of the

* Miss Jervym's Butterfly Coilector, p. 11. 
world, and playing its part there under so many different masks?" The ancients were so struck with the transformations of the butterfly, and its revival from a seeming temporary death, as to have considered it an emblem of the soul, the Greek word $\psi v x \eta$ signifying both the soul and a butterfly; and it is for this reason that we find the butterfiy introduced into their allegorical sculptures as an emblem of immortality. Trifling, therefore, and perhaps contemptible, as to the unthinking may seem the study of a butterfly, yet when we consider the art and mechanism displayed in so minute a structure,- - the fluids circulating in vessels so small as almost to escape the sight-the beauty of the wings and covering-and the manner in which each part is adapted for its peculiar functions,-we cannot but be struck with wonder and admiration, and allow, with Paley, that " the production of beauty was as much in the Creator's mind in painting a butterfly as in giving symmetry to the human form."

A collection of insects is to the true naturalist what a collection of medals is to the accurate student of history. The mere collector, who looks only to the shining wings of the one, or the green rust of the other, derives little knowledge from his pursuit. But the cabinet of the entomologist becomes rich in the most interesting subjects of contemplation, when he regards it in the genuine spirit of scientific inquiry. What, for instance, can be so delightful as to examine the wonderful variety of structure in this portion of the creation; and, above all, to trace the beautiful gradations by which one species runs into another. Their differences are so minute, that an unpractised eye would proclaim their identity ; and yet, when the species are separated, and not very distantly, they become visible even to the common observer. It is in examinations such as these that 
the naturalist finds a delight of the highest order. While it is thus one of the legitimate objects of his study to attend to minute differences of structure, form, and colouring, he is not less interested in the investigation of habits and economy; and in this respect the insect world is inexhaustibly rich. We find herein examples of instinct to parallel those of all the larger animals, whether they are solitary or social; and innumerable others besides, altogether unlike those manifested in the superior departments of animated nature. These instincts have various directions, and are developed in a more or less striking manner to our senses, according to the force of the motive by which they are governed. Some of their instincts have for their object the preservation of insects from external attack; some have reference to procuring food, and involve many remarkable stratagems; some direct their social economy, and regulate the condition under which they live together either in monarchies or republics, their colonizations, and their migrations: but the most powerful instinct which belongs to insects has regard to the preservation of their species. We find, accordingly, that as the necessity for this preservation is of the utmost importance in the economy of nature, so for this especial object many insects, whose offspring, whether in the egg or the larva state, are peculiarly exposed to danger, are endued with an almost miraculous foresight, and with an ingenuity, perseverance, and unconquerable industry, for the purpose of avoiding those dangers, which are not to be paralleled even by the most singular efforts of human contrivance. The same ingenuity which is employed for protecting either eggs, or caterpillars and grubs, or pupæ and chrysalides, is also exercised by many insects for their own preservation against the changes of temperature to which they are exposed, or against their natural enemies. Many voL. Iv. 
species employ those contrivances during the period of their hybernation, or winter-sleep. For all these purposes some dig holes in the earth, and form them into cells; others build nests of extraneous substances, such as bits of wood and leaves; others roll up leaves into cases, which they close with the most curious art; others build a house of mud, and line it with the cotton of trees, or the petals of the most delicate flowers; others construct cells, of secretions from their own bodies; others form cocoons, in which they undergo their transformation; and others dig subterraneous galleries, which, in complexity of arrangement, in solidity, and in complete adaptation to their purposes, vie with the cities of civilized man. The contrivances by which insects effect these objects have been accurately observed and minutely described, by patient and philosophical inquirers, who knew that such employments of the instinct with which each species is endowed by its Creator oflered the most valuable and instructive lessons, and opened to them a wide field of the most delightful study. The construction of their habitations is certainly among the most remarkable peculiarities in the economy of insects; and it is of this subject that we propose to treat under the general name, which is sufficiently applicable to our purpose, of INSECT Architecture. 
Is the descriptions which we shall give of Insect Architecture, we shall employ as few technical words as possible; and such as we cannot well avoid, we shall explain in their places: but, since our subject chiefly relates to the reproduction of inserts, it may be useful to many readers to introduce here a briet description of the changes which they undergo.

It was of old believed that insects were produced spontaneously by putrefying substances; and Virgil gives the details of a process for creating a swarm of bees out of the carcase of a bull: but Redi, a celebrated Italian naturalist, proved by rigid experiments that they are always, in such cases, hatched from eggs previously laid. Most insects, indeed, lay eggs, though some few are viviparous, and some, like serpents, propagate both ways. The eggs of insects are very various in form, and seldom shaped like those of birds. We have here figured those of several species, as they appear under the microscope.
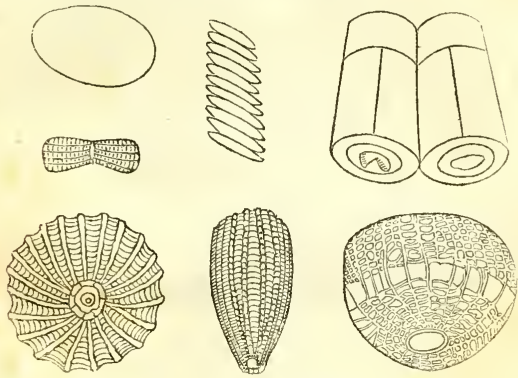

Eggs of Insects.-Magnified. 
When an insect first issues from the egg, it is called by naturalists larva, and, popularly, a caterpillar, a grub, or a maggot. The distinction, in popular language, seems to be, that caterpillars are produced from the eggs of moths or butterflies; grubs, from the eggs of beetles, bees, wasps, \&c.; and maggots (which are without feet) from blow-flies, house-flies, cheese-flies, \&c., though this is not very rigidly adhered to in common parlance. Maggots are also sometimes called worms, as in the instance of the meal-worm; but the common earth-worm is not a larva, nor is it by modern naturalists ranked among insects.

Larvæ are remarkably small at first, but grow rapidly The full-grown caterpillar of the goat-moth (Cossus ligniperda) is thus seventy-two thousand times heavier than when it issues from the egg; and
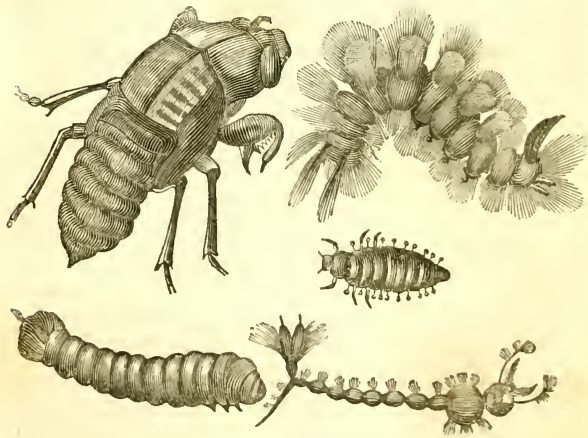

Larra, Grubs, Caterpillars, or Maggats. 
the maggot of the blow-fly is, in twenty-four hours, one hundred and fifty-five times heavier than at its birth Some larvæ have feet, others are without: none have wings. They cannot propagate. They feed voraciously on coarse substances; and as they increase in size, which they do very rapidly, they cast their skins three or four times. In defending themselves from injury, and in preparing for their change by the construction of secure abodes, they manifest great ingenuity and nechanical skill. The figures on the preceding page, exemplify various forms of insects in this stage of their existence.

When larvæ are full grown, they cast their skins for the last time, undergo a complete change of form, and, with a few exceptions, cease to eat, and remain nearly motionless. When an insect, after this change, does not lose its legs, or continues to eat and move, it is popularly called a Nymph; and when the inner skin of the larva is converted into a membranous or leathery covering, which wraps the insect closely up like a mummy, it is termed Pupa, from its resem-

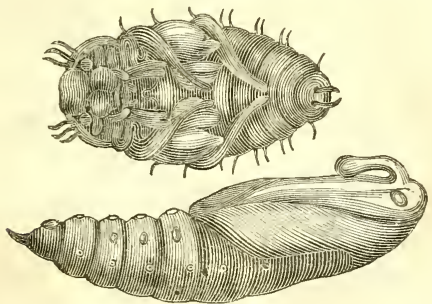

Pupce or Chrysalides.

blance to an infant in swaddling bands. From the pupæ of many of the butterflies appearing gilt as if 
with gold, the Greeks called them Chrysalides, and the Romans Aurelice, and hence naturalists frequently call a pupa chrysalis, even when it is not gilt. We shall see, as we proceed, the curious contrivances resorted to for protecting insects in this helpless state. After a certain time, the insect which has remained in its pupa-case, like a mass of jelly without shape, is gradually preparing for its final change, when it takes the form of a perfect insect. This state was called by Linnæus, Imago, because the insect, having thrown off its mask, becomes a perfect image of its species. Of some, this last portion of their existence is very short, others live

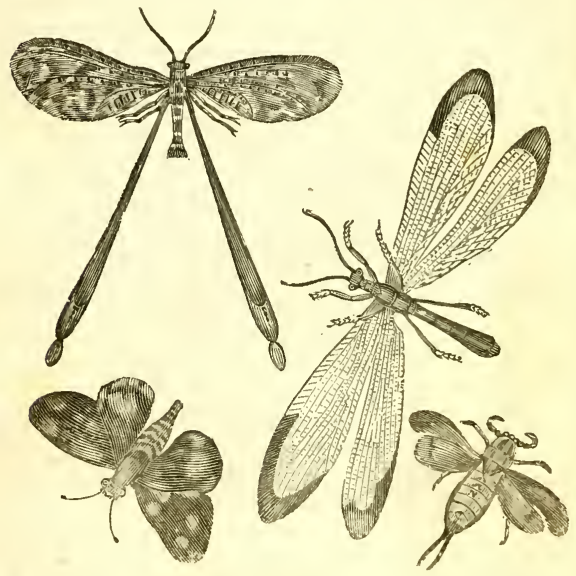

Insects in the Imago or perfect state. 
through a year, and some exist for longer periods. They feed lightly, and never increase in size. The chief object of all is to perpetuate their species, after which the greater number quickly die. It is in this state that they exercise those remarkable instincts for the preservation of their race, which are exhibited in their preparations for the shelter of their eggs, and the nourishment of their larvæ. The foregoing are examples of insects in the imago, or perfect state. 


\section{Chapter II.}

Structures for protccting Eggs.-Mason-Wasps; Mason-Bees; Mining Bees.

THe provisions which are made by the difierent species of insects for protecting their eggs, appear in many cases to be admirably proportioned to the kind of danger and destruction to which they may be exposed. The eggs themselves, indeed, are not so liable to depredation and injury as the young brood hatched from them; for, like the seeds of plants, they are eapable of withstanding greater degrees both of heat and cold than the insects which produce them. Aceording to the experiments of Spallanzani, the eggs of frogs that had been exposed to various degrees of artificial heat, were searcely altered in their produetive powers by a temperature of $111^{\circ}$ of Fahrenheit, but they became corrupted after $133^{\circ}$. He tried the same experiment upon tadpoles and frogs, and found they all died at $111^{\circ}$. Silk-worms died at a temperature of $108^{\circ}$, while their eggs did not entirely cease to be fertile till $144^{\circ}$. 'The larva of flesh-flies perished, while the eggs of the same species continued fertile, at about the same comparative degrees of heat as in the preceding instances. Intense cold has a still less effect upon eggs than extreme heat. Spallanzani exposed the eggs of silk-worms to an artificial cold $23^{\circ}$ below zero, and yet, in the subsequent spring, they all produced caterpillars. Insects almost invariably dic at the temperature of $14^{\circ}$, that is at $18^{\circ}$ below the freezing point.* The care of insects for the pro-

* Sce Spallanzani's 'I'racts, by Dalyel, vol. i. 
tection of their eggs is not entirely directed to their preservation in the most favourable temperature for being hatched, but to secure them against the numerous enemies which would attempt their destruction; and, above all, to protect the grubs when they are first developed, from those injuries to which they are peculiarly exposed. Their prospective contrivances for accomplishing these objects are in the highest degree curious.

Most persons have more or less acquaintance with the hives of the social species of bees and wasps: but little is generally known of the nests constructed by the solitary species, though in many respects these are not inferior to the others in displays of ingenuity and skill. We admire the social bees, labouring together for one common end, in the same way that we look with delight upon the great division of labour in a well-ordered manufactory. As in a cotton-mill, some attend to the carding of the raw material, some to its formation into single threads, some to the gathering these threads upon spindles, others to the union of many threads into one,-all labouring with invariable precision because they attend to a single object; - so do we view with delight and wonder the successive steps by which the hive-bees bring their beautiful work to its completion,-striving, by individual efforts, to accomplish their gencral task, never impcding each other by useless assistance, each taking a particular department, and each knowing its own duties. We may, however, not the less admire the solitary wasp or bee, who begins and finishes every part of its destined work; just as we admire the ingenious mechanic who perfects something useful or ornamental entirely by the labour of his own hands, - whether he be the patient Chinese carver, who cuts the most elaborately decorated boxes out of a sold picce of ivory, or the

VOL. IV. 
turner of Europe, who produces every variety of elegant form by the skilful application of the simplest means.

Our island abounds with many varieties of solitary wasps and bees; and their nests may therefore be easily discovered by those who, in the proper seasons, are desirous of observing the peculiarities of their architecture.

\section{Mason-Wasps.}

In September, 1828, a common species of solitary mason-wasp (Odynerus, LATr.) was observed by us*

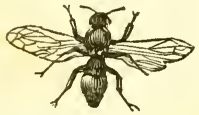

Odynerus.-Natural size.

on the east wall of a house at Lee, in Kent, very busy in excavating a hole in one of the bricks, about five feet from the ground. Whether there might not have been an accidental hole in the brick, before the wasp commenced her labours, is unknown, as she had made considerable progress in the work when first observed; but the brick was one of the hardest of the yellow sort made in this neighbourhood. The most remarkable circumstance in the process of hewing into the brick, was the care of the insect in removing to a distance the fragments which from the time to time she succeeded in detaching. It di dnot appear to suit her design to wear down the brick, particle by particle, as the furniture beetle (Anobium pertinax) does, in making its pin-hole galleries in old wood. Our wasp-architect, on the contrary, by means of her strong tranchant-toothed jaws, severed 


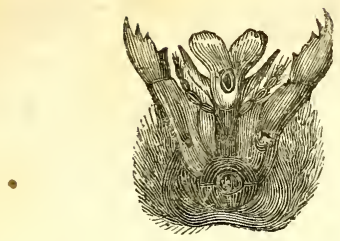

Mandibťes-Jaws of Mason-Wasp,-Greatly magnified.

a piece usually about the bigness of a mustard-seed. It might have been supposed that these fragments would have been tossed out of the hole as the work proceeded, without further concern; as the mole tosses above ground the earth which has been cleared out of its subterranean gallery. The wasp was of a different opinion; for it was possible that a heap of brick chips, at the bottom of the wall, might lead to the discovery of her nest by some of her enemies; particularly by one or other of the numerous tribe of what are called ichneumon flies. This name is given to them, from the similarity of their habit of destroying eggs to that of the little animal which proves so formidable an enemy to the multiplication of the crocodile of Egypt. They may be also denominated cuckoo flies, because, like that bird, they thrust their egg into the nest of another species. These flies are continually prowling about and prying into every corner, to find, by stealth, a nidus for their eggs. It might have been some such consideration as this which induced the wasp to carry off the fragments as they were successively detached. That concealment was the motive, indeed, was proved ; for one of the fragments which fell out of the hole by 
accident, she immediately sought for at the bottom of the wall, and carried off like the rest. It was no easy matter to get out one of the fragments, as may readily be conceived when the size of the insect is compared with that of the entrance, of which this ) is the 'exact size, as taken from the impression of a bit of dough upon the hole when finished. It was only by seizing the fragment with her jaws, and retreating backwards, that the matter could be accomplished; though, after the interior of the excavation was barely large enough to admit of her turning round, she more than once attempted to make her exit head-foremost, but always unsuccessfully. The weight of the fragments removed did not appear to impede her flight, and she generally returned to her task in about two or three minutes.

Within two days the excavation was completed; but it required two other days to line it with a coating of clay, to deposit the eggs, two in number, and, no doubt, to imprison a few live spiders or caterpillars, for the young when hatched,-a process which was first observed by Ray and Willoughby*, but which has since been frequently ascertained. ' In the present instance, this peculiarity was not seen; but the little architect was detected in closing up the entrance, which was formed of a layer of clay more than double the thickness of the interior lining. In November following; we hewed away the brick around this nest, and found the whole cxcavation was rather less than an inch in depth.

Notwithstanding all the precautions of the careful parent to conceal her nest, it was found out by one of the cuckoo flies (Tachina larvarum?) - probably a common species very similar to the house-fly, but

* Ray, Uist. Insect. 254. 


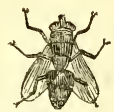

Cuckoo-Fly-Tachina larca'um?) -Natural size .

rather larger, which deposited an egg there ; and the grub hatched from it, after devouring one of the waspgrubs, formed itself a cocoon $(a)$, as did the other

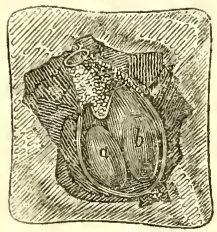

Mason-Wasp's Ncst and Cocoons.-About one-third the natural size. undevoured grub of the wasp $(b)$. Both awaited the return of summer to change into winged irsects, burst their cerements, and proceed as their parents did.

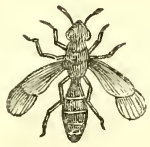

Mason-Wasp-(Odyneris murarins)-Naturai size.

Another mason wasp (Odynerus murarius, LATr.) differing little in appearance from the former, may often be seen frequenting sandy banks exposed to the sun, and constructing its singular burrows, vor. iv. 
The sort of sand-bank which it selects is hard and compact; and though this may be more difficult to penetrate, the walls are not liable to fall down upon the little miner. In such a bank, the mason-wasp bores a tubular gallery two or three inches deep. The sand upon which Reaumur found some of these wasps at work was almost as hard as stone, and yielded with difficulty to his nail ; but the wasps dug into it with ease, having recourse, as lie ascertained, to the ingenious device of moistening it by letting fall two or three drops of fluid from their mouth, which rendered the mass ductile, and the separation of the grains easy to the double pickaxe of the little pioneers.

When this wasp has detached a few grains of the moistened sand, it kneads them together into a pellet about the size of one of the seeds of a gooseberry. With the first pellet which it detaches, it lays the foundation of a round tower, as an outwork, inmediately over the mouth of its nest, Every pellet which it afterwards carries off from the interior is added to the wall of this outer round tower, which advances in height as the hole in the sand increases in deptll. Every two or three minutes, however, during these operations, it takes a short excursion, for the purpose, probably, of replenishing its store of fluid wherewith to moisten the sand. Yet so little time is lost, that Réaumur has seen a mason-wasp dig in an hour a hole the length of its body, and at the same time build as much of its round tower. For the greater part of its height this round tower is perpendicular; but towards the summit it bends into a curve, corresponding to the bend of the insect's body, which, in all cases of insect architecture, is the model followed. The pellet which form the walls of the tower are not very nicely joined, and numerous vacuities are left 


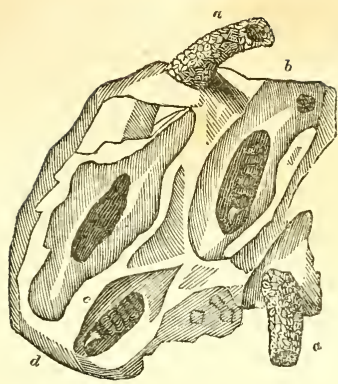

Nests, \&c. of Mrson-Wasps.-About half the natural size.$a$ The tower of the nest. $b$ The entrance after the tower is removod. $c$ The cell. $d$ The cell, with a roll of caterpillars prepared for the larva.

between them, giving it the appearance of fillagree work. That it should be thus slightly built is not surprising, for it is intended as a temporary structure for protecting the insect while it is excavating its hole; and as a pile of materials, well arranged and ready at hand, for the completion of the interior building,-in the same way that workmen make a regular pile of bricks near the spot where they are going to build. This seems, in fact, to be the main design of the tower, which is taken down as expeditiously as it had been reared. Réaumur thinks, that by piling in the sand which has previously been dug out, the wasp intends to guard its progeny for a time fiom being exposed to the too violent heat of the sun; and he has even sometimes seen that there were not sufficient materials in the tower, in which case the wasp had recourse to the rubbish she had thrown 
out after a tower was completed. By raising a tower of the materials which she excavates, the wasp produces the same shelter from external heat, as a human creature would who chose to inhabit a deep cellar of a high house. She further protects her progeny from the ichneumon fly, as the engineer constructs an outwork to render more difficult the approach of an enemy to the citadel. Ricaumur has seen this indefatigable enemy of the wasp peep into the mouth of the tower and then retreat, apparently frightened at the depth of the cell which he was anxious to invade.

The mason-wasp does not furnish the cell she has thus constructed with pollen* and honey, like the solitary bees, but with living caterpillars, and these always of the same species, - being of a green colour, and without feet. She fixes the caterpillars together in a spiral column: they cannot alter their position, although they remain alive. They are an easy prey to their smaller enemy; and when the grub has eaten them all up, it spins a case, and is transformed into a nymph, which afterwards becomes a wasp. The number of caterpillars which is thus found in the lower cavity of the mason-wasp's nest is ordinarily from ten to twelve. The mother is careful to lay in the exact quantity of provision which is necessary to the growth of the grub before he quits his retreat. He works through his store till his increase in this state is perfected, and he is on the point of undergoing a change into another state, in which he requires no food. The careful purveyor, cruel indeed in her choice of a supply, but not the less directed by an unerring instinct, selects such caterpillars as she is conscious have completed their growth, and will remain thus imprisoned without increase or cor-

* The prolific powder of flowers. 
ruption till their destroyer has gradually satisfied the necessities of his being. "All that the worm of the wasp," says Raumur, "has to do in his nest, from his birth to his transformation, is to cat." There is another species of wasp which does not at once enclose in its nest all the sustenance which its larva will require before transformation, but which, from time to time, imprisons a living caterpillar, and when that is consumed opens the nest and introduces another.**

\section{Mason-Bees.}

It would not be easy to find a more simple, and, at the same time, ingenious specimen of insect architecture, than the nests of those species of solitary bees, which have been justly called mason-bees (Megachile, Latreille.) Réaumur, who was struck by the analogies between the proceedings of insects and human arts, first gave to bees, wasps, and caterpillars those names which indicate the character of their labours; and which, though they may be considered a little fanciful, are at least calculated to arrest the attention. The nests of mason-bees are constructed of various materials; some with sand, some with earth mixed with chalk, and some with a mixture of earthy substances and wood.

On the north-east wall of Greenwich Park, facing the road, and about four feet from the ground, we discovered, $\uparrow$ December 10th, 1828, the nest of a mason-bee, formed in the perpendicular line of cement between two bricks. Externally there was an irregular cake of dry mud, precisely as if a handful of wet road-stuff had been taken from a cart-rut and thrown against the wall; though, upon closer inspection, the cake contained more small stones

* Bonnet, Contemplation, \&c. 1. xii. c. 41 + J. R. 


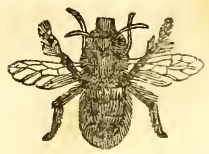

Mason-Bee-(Anthophora retusa).-Nitural size.

than usually occur in the mud of the adjacent cartnotice, had there not been a circular hole on one side of it, indicating the perforation of some insect. This

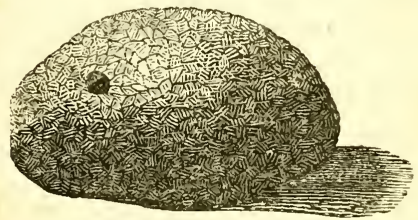

Exterior wall of Masun-Bet's nest.

hole was found to be the orifice of a cell about an inch deep, exactly of the form and size of a lady's thimble, finely polished, and of the colour of plaster of Paris, but stained in various places with yellow.

This cell was empty; but upon removing the cake of mud, we discovered another cell, separated from the former by a partition about a quarter of an inch thick, and in it a living bee, from which the preccding figure was drawn, and which, as we supposed, had just changed from the pupa into the winged state, in consequence of the uncommon mildness of the weather. The one which had occupied the adjacent cell 
had, no doubt, already dug his way out of its prison, and would probably fall a victim to the first frost.

Our nest contained only two cells-perhaps from there not being room between the bricks for more.

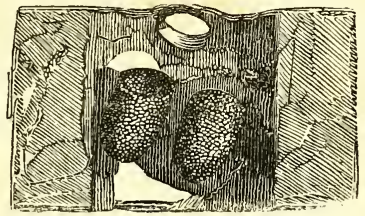

Cells of a Mason-Bee (Anthophores retusa.)-One third the natural size.

An interesting account is given by Réaumur of another mason-bee (Megachile muraria), selecting earthy sand, grain by grain; her gluing a mass of these together with saliva, and building with them her cells from the foundation. But the cells of the Greenwich Park nest were apparently composed of the mortar of the brick wall; though the external covering seems to have been constructed as Réaumur describes his nest, with the occasional addition of small stones.

About the middle of May, 1829, we discovered the mine from which all the various species of mason-bees in the vicinity seemed to derive materials for their nests.* It was a bank of brown clay, facing the east, and close by the margin of the river Ravensbourn, at Lee, in Kent. The frequent resort of the bees to this spot attracted the attention of some workmen, who, deceived by their resemblance to wasps, pointed it out as a wasp's nest; though they were not a little surprised to see so numerous a colony at this early season. As the bees had dug a hole in the bank, 
where they were incessantly cntering and re-appearing, we were of opinion that they were a peculiar sort of the social earth bees (Bombus). On approaching the spot, however, we remarked that the bees were not alarmed, and manifested none of the irritation usual in such cases, the consequence of jealous affection for their young. This led us to observe their operations more minutely; and we soon discovered that on issuing from the hole each bee carried out in its mandibles a piece of clay. Still supposing that they were social earth bees, we concluded that they were busy excavating a hollow for their nest, and carrying off the refuse to prevent discovery. The mouth of the hole was overhing, and partly concealed by a large pebble. This we removed, and widened the entrance of the hole, intending to dig down and ascertain the state of the operations; but we soon found that it was of small depth. The bees, being scared away, began scooping out elay from another hole about a yard distant from the first. Upon our withdrawing a few feet from the first hole, they returned thither in preference, and continued assiduously digging and removing the clay. It became obvious, therefore, from their thus changing place, that they were not constructing a nest, but merely quarrying for clay as a building material. By catching one of the bees (Osmia bicornis) when it was loaded with its burden, we ascertaincd that the elay was not only carefully kneaded, but was also more moist than the mass from which it had been taken. The bce, therefore, in preparing the pellet, which was nearly as large as a garden pea, had moistened it with its saliva, or some similar fluid, to render it, we may suppose more tenacious, and better fitted for building. The reason of their dirging a hole, instead of taking clay indiscriminately fiom the bank, appeared to be for the purpose of economizing their saliva, as 
the weather was dry, and the clay at the surface was parched and hard. It must have been this circumstance which induced them to prefer digging a hole, as it were in concert, though each of them had to build a separate nest.

The distance to which they carried the clay was probably considerable, as there was no wall near, in the direction they all flew towards, upon which they could build; and in the same direction also, it is worthy of remark, they could have procured much nearer the very same sort of clay. Whatever might be the cause of their preference, we could not but admire their extraordinary industry. It did not require more than half a minute to knead one of the pellets of clay; and from their frequent returns, probably not more than five minutes to carry it to the nest, and apply it, were wanted. From the dryness of the weather, indeed, it was indispensable for them to work rapidly, otherwise the clay could not have been made to hold together. The extent of the whole labour of forming a single nest may be imagined, if we estimate that it must take several hundred pellets of clay for its completion. If a bee work fourteen or fifteen hours a day, therefore, carrying ten or twelve pellets to its nest every hour, it will be able to finish the structure in about two or three days; allowing some hours of extra time for the more nice workmanship of the cells in which the eggs are to be deposited, and the young grubs reared.

That the construction of such a nest is not a merely agreeable exercise to the mason-bee has been sufficiently proved by M. Du Hamel. He has observed a bee (Mcgachile miraria) less careful to perform the necessary labour for the protection of her offspring than those we have described; but, not less desirous of obtaining this protection, attempt to VOL. IV. 
usurp the nest which another had formed. A fierce battle was invariably the consequence of this attempt; for the true mistress would never give place to the intruder. The motive for the injustice and the resistance was an indisposition to further labour. The trial of strength was probably, sometimes, of as little use in establishing the right as it is amongst mankind; and the proper owner, exhausted by her efforts, had doubtless often to surrender to the dishonest usurper.

The account which Réaumur has given of the operations of this class of bees differs considerably from that which we have here detailed; from the species being different, or from his bees not having been able to procure moist clay. On the contrary, sand was the chief material used by his mason-bees (Megachile muraria) ; which they had the patience to select from the walks of a garden, and knead into a paste or mortar, adapted to their building. They had consequently to expend a much greater quantity of saliva, than our bees (Osmia bicornis) which worked with moist clay. Réaumur, indeed, ascertained that every individual grain of sand is moistened previous to its being joined to the pellet, in order to make it adhere more effectually. The tenacity of the mass is besides rendered stronger, he tells us, by adding a proportion of earth or garden mould. In this manner, a ball of mortar is formed, about the size of a small shot, and carrieci off to the nest. When the structure of this is examined, it has all the appearance externally of being composed of earth and small stones or gravel. The ancients, who were by no means accurate naturalists, having observed bees carrying pellets of earth and small stones, supposed that they employed these to add to their weight, in order to steady their flight when impeded by the wind.

The nests thus constructed appear to have been 
more durable edifices than those which have fallen under our observation;-for Réaumur says they were harder than many sorts of stone, and could scarcely be penetrated with a knife. Ours, on the contrary, do not seem harder than a piece of sunbaked clay, and by no means so hard as brick. One circumstance appeared inexplicable to Réaumur and his friend Du Hamel, who studied the operations of these insects in concert. After taking a portion of sand from one part of the garden-walk, the bees usually took another portion from a spot almost twenty and sometimes a hundred paces off, though the sand, so far as could be judged by close examination, was precisely the same in the two places. We should be disposed to refer this more to the restless character of the insect, than to any difference in the sand. We have observed a wasp paring the outside of a plank, for materials to form its nest; and though the plank was as uniform in the qualities of its surface, nay, probably more so than the sand could be, the wasp fidgeted about, nibbling a fibre from one, and a fibre from another portion, till enough was procured for one load. In the same way, the whole tribe of wasps and bees flit restlessly from flower to flower, not unfrequently revisiting the same blossom, again and again, within a few seconds. It appears to us, indeed, to be far from improbable, that this very restlessness and irritability may be one of the springs of their unceasing industry.

By observing, with some care, the bees which we found digging the clay, we discovered one of them (Osmia bicornis) at work upon a nest, about a gunshot from the bank. The place it had chosen was the inner wall of a coal-house, facing the south-west, the brick-work of which was but roughly finished. In an upright interstice of half an inch in width, between two of the bricks, we found the little architect 
assiduously building its walls. The bricklayer's mortar had either partly fallen out, or been removed by the bee, who had commenced building at the lower end, and did not build downwards, as the social wasps construct their cells.

The very different behaviour of the insect here, and at the quarry, struck us as not a little remarkable. When digging and preparing the clay, our approach, however near, produced no alarm; the work went on as if we had been at a distance; and though we were standing clcse to the hole, this did not scare away any of the bees upon their arrival to procure a fresh load. But if we stood near the nest, or even in the way by which the bee flew to it, she turned back or made a wide circuit immediatcly, as if afraid to betray the site of her domicile. We even observed her turning back, when we were so distant that it could not reasonably be supposed she was jealous of us; but probably she lad detected some prowling insect-depredator, tracking her flight with designs upon her provision for her future progeny. We imagined we could perceive not a little art in her jealous caution, for she would alight on the tiles as if to rest herself; and even when she had entered the coal-house, she did not go directly to her nest, but again rested on a shelf, and at other times pretended to examine several crevices in the wall, at some distance from the nest. But when there was nothing to alarm her, she flew directly to the spot, and began eagerly to add to the building.

It is in instances such as these, which exhibit the adaptation of instinct to circumstances, that our reason finds the greatest difficulty, in explaining the governing principle of the minds of the inferior animals. The mason-bee makes her nest by an invariable rule; the model is in her mind, as it has becn in the mind of her race from their first creation: they 
have learnt nothing by experience. But the mode in which they accomplish this task varies according to the situations in which they are placed. They appear to have a glimmering of reason, employed as an accessary and instrument of their instinct.

The structure, when finished, consisted of a wall of clay supported by two contiguous bricks, enclosing six chambers, within which a mass of pollen, rather larger than a cherry-stone, was deposited, together with an egg, from which in due time a grub was batched. Contrary to what has been recorded by preceding naturalists, with respect to other mason-bees, we found the cells in this instance quite parallel and perpendicular; but it may also be remarked, that the

1

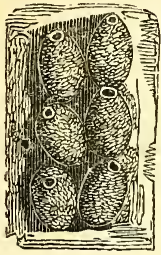

2

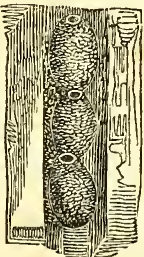

3

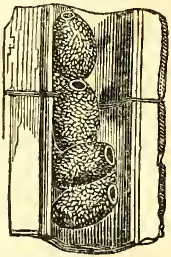

Cells of Mason-Bees, built, in the first and second figures, by Osmia bicornis between bricks. and in the third, hy Megachilt muraria in the fluting of an old pilaster; about half the natural size.

bee itself was a species altogether different from the one which we have described above as the Anthophora retusa, and agreed with the figure of the one we caught quarrying the clay-(Osmia bicornis.)

There was one circumstance attending the proceedings of this mason-bee which struck us not a little, though we could not explain it to our owi vol.. IV. 
satisfaction. Every time she left her nest for the purpose of procuring a fresh supply of materials, she paid a regular visit to the blossoms of a lilac tree which grew near. Had these blossoms afforded a supply of pollen, with which she could have replenished her cells, we could have easily understood her design; but the pollen of the lilac is not suitable for this purpose, and that she had never used it was proved by all the pollen in the cells being yellow, whereas that of the lilac is of the same pale, purple colour as the flowers. Besides, she did not return immediately from the lilac tree to the building, but always went for a load of clay. There seemed to us, therefore, to be only two ways to explain the circumstance:-she must either have applied to the lilac blossoms to obtain a refreshment of honey, or to procure glutinous materials to mix with the clay.

When employed upon the building itself, the bee exhibited the restless disposition peculiar to most hymenopterous* insects; for she did not go on with one particular portion of her wall, but ran about from place to place every time she came to work. At first, when we saw her running from the bottom to the top of her building, we naturally imagined that she went up for some of the bricklayer's mortar to mix with her own materials; but upon minutely examining the walls afterwards, no lime could be discovered in their structure, similar to that which was apparent in the nest found in the wall of Greenwich Park.

Réaumur mentions another sort of mason-bee, which selects a small cavity in a stone, in which she forms her nest of garden mould moistened with gluten, and afterwards closes the hole with the same material.

* The fifth order of Linnæus; insects with four transparent veined wings. 


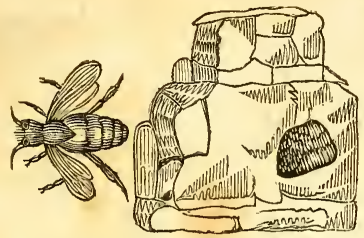

Mason-Bee and Nest-From Reaumur.

\section{Mining-Bees.}

A very small sort of bees (Andrence), many of them not larger than a house-fly, dig in the ground tubular galleries little wider than the diameter of their own bodies. Samouelle says, that all of them seem to prefer a southern aspect; but we have found them in banks facing the east, and even the north. Immediately above the spot where we have described the mason-bees quarrying the clay, we observed several holes, about the diameter of the stalk of a tobacco-pipe, into which those little bees were seen passing. The clay here was very hard; and on passing a straw into the hole as a director, and digging down for six or eight inches, a very smooth circular gallery was found, terminating in a thimble-shaped horizontal chamber, almost at right angles to the entrance, and nearly twice as wide. In this chamber

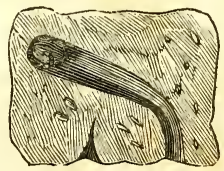

Cell of Mining-Bee (Andrena),-About half the natural size. 
there was a ball of bright yellow pollen, as round as a garden pea, and rather larger, upon which a small white grub was feeding; and to which the mother bee had been adding, as she had just entered a minute before with her thighs loaded with pollen. That it was not the male, the load of pollen determined; for the male has no apparatus for collecting or transporting it. The whole labour of digging the nest and providing food for the young is performed by the female. The females of the solitary bees have no assistance in their tasks. The males are idle; and the females are unprovided with labourers, such as the queens of the hive command.

Réaumur mentions that the bees of this sort, whose operations he had observed, piled up at the entrance of their galleries the earth which they had scooped out from the interior; and when the grub was hatched, and properly provided with food, the earth was again employed to close up the passage, in order to prevent the intrusion of ants, ichneumon flies, or other depredators. In those which we have observed, this was not the case; but every species differs from another in some little peculiarity, though they agree in the general principles of their operations. 


\section{Chapter III. \\ Carpenter-Bees ; Carpenter-Wisps ; Upholsterer-Bees. \\ Carpenter-Bees.}

Arrong the solitary bees are several British species which come under that class called carpenter-bees by M. Reaumur, from the circumstance of their working in wood, as the mason-bees work in stone. We have frequently witnessed the operations of these ingenious little workers, who are particularly partial to posts, palings, and the wood-work of houses which has become soft by beginning to decay. Wood actually decayed, or affected by dry-rot, they seem to reject as unfit for their purposes; but they make no objections to any hole previously drilled, provided it be not too large; and, like the mason-bees, they not unfrequently take possession of an old nest, a few repairs being all that in this case is necessary.

When a new nest is to be constructed, the bee proceeds to chisel sufficient space for it out of the wood with her jaws. We say her, because the task in this instance, as in most others of solitary bees and wasps, devolves solely upon the female, the male taking no concern in the affair, and probably being altogether ignorant that such a work is going forward. It is, at least, certain that the male is never seen giving his assistance, and he seldom, if ever, approaches the neighbourhood. The female carpenter-bee has a task to perform no less arduous than the mason-bee; for though the wood may be tolerably soft, she can 
only cut out a very small portion at a time. The successive portions which she gnaws off may be readily ascertained by an observer, as she carries them away from the place. In giving the history of a masonwasp (Odynerus), at page 25, we remarked the care with which she carried to a distance little fragments of brick, which she detached in the progress of excavation. We have recently watched a precisely similar procedure in the instance of a carpenter-bee forming a cell in a wooden post.* The only difference was, that the bee did not fly so far away with her fragments of wood as the wasp did; but she varied the direction of her flight every time: and we could observe, that after dropping the chip of wood which she had carried off, she did not return in a direct line to her nest, but made a circuit of some extent before wheeling round to go back.

On observing the proceedings of this carpenter-bee next day, we found her coming in with balls of pollen on her thighs; and on tracing her from the nest into the adjacent garden, we saw her visiting every flower which was likely to yield her a supply of pollen for her future progeny. This was not all: we subsequently saw her taking the direction of the clayquarry frequented by the mason-bees, as we have mentioned in page 35, where we recognized her loading herself with a pellet of clay, and carrying it into her cell in the wooden post. We observed her alternating this labour for several days, at one time carrying clay, and at another pollen; till at length she completed her task, and closed the entrance with a barricado of clay, to prevent the intrusion of any insectivorous depredator, who might make prey of her young; or of some prying parasite, who might introduce its own eggs into the nest she had taken so much trouble to construct. 

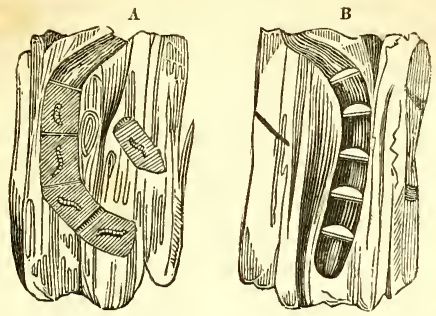

Cells of Carpenter-Bees, excavated"in an old post.-In fig.A the cells contain the young grubs; in fig. $B$ the cells are empty. Both figures are shown in section, and about half the natural size.

Some days after it was finished, we cut into the post, and exposed this nest to view. It consisted of six cells of a somewhat square shape, the wood forming the lateral walls; and each was separated from the one adjacent by a partition of clay, of the thickness of a playing card. The wood was not lined with any extraneous substance, but was worked as smooth as if it had been chiselled by a joiner. There were five cells, arranged in a very singular manner-two being almost horizontal, two perpendicular, and one oblique.

The depth to which the wood was excavated, in this instance, was considerably less than what we have observed in other species which dig perpendicular galleries several inches deep in posts and garden-seats; and they are inferior in ingenuity to the carpentry of a bee described by Rèaumur (Xylocopa violacea), which has not been ascertained to be a native of Britain, though a single indigenous species of the genus has been doubtingly mentioned, and is 
figured, by Kirby, in his valuable 'Monographia.' If it ever be found here, its large size and beautiful violet-coloured wings will render mistakes impossible.

The violet carpenter-bee usually selects an upright piece of wood, into which she bores obliquely for about an inch; and then, changing the direction, works perpendicularly, and parallel to the sides of the wood, for twelve or fifteen inches, and a half an inch in breadth. Sometimes the bee is contented with one or two of these excavations ; at other times, when the wood is adapted to it, she scoops out three or four-a task which sometimes requires several weeks of incessant labour.

The tunnel in the wood, however, is only one part of the work; for the little architect has afterwards to divide the whole into cells, somewhat less than an inch in depth. It is necessary, for the proper growth of her progeny, that each should be separated from the other, and be provided with adequate food. She knows, most exactly, the quantity of food which each grub will require, during its growth ; and she therefore does not hesitate to cut it off from any additional supply. In constructing her cells, she does not employ clay, like the bee which we have mentioned above, but the saw dust, if we may call it so, which she has collected in gnawing out the gallery. It would not, therefore, have suited her design to scatter this about, as our carpenter-bee did. The violet bee, on the contrary, collects her gnawings into a little store-heap for future use, at a short distance from her nest. She proceeds thus;-at the bottom of her excavation she deposits an egg, and over it fills a space nearly an inch high with the pollen of flowers, made into a paste with honey. She then covers this over with a ceiling composed of cemented sawdust, which also serves for the floor of the next chamber above it. For this 

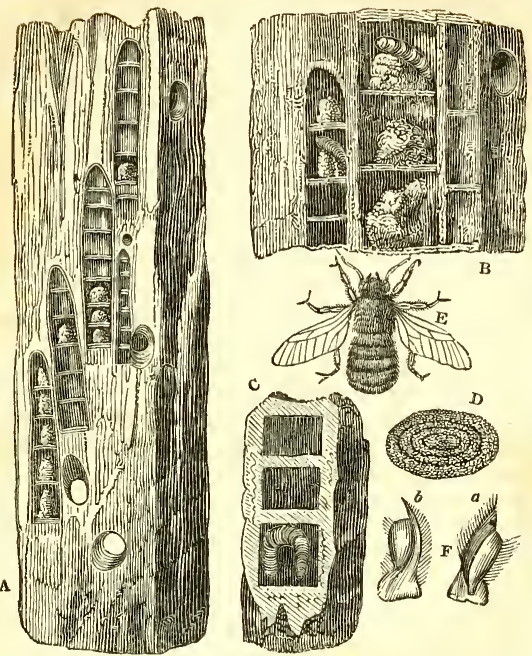

A. represents a part of an espalier prop, tunnelled in several places by the violet carpenter-bee: the stick is split, and shows the nests and passages by which they are approached. B, a portion of the prop, halt the natural size. $\quad c$, a piece of thin stick, pierced by the carpenter-bee, and split, to show the nests. D. Perspective view of nne of the partitions. E, Carpenter-bee ( $\boldsymbol{X}_{\text {ylocopa }}$ violacea). F, Teetli of the carpenter-bee, greatly magnified: $\alpha$, the upper side; $b$, lower side

purpose, she cements round a wall a ring of wood chips, taken from her store heap ; and within this ring forms another, gradually contracting the diameter till she has constructed a circular plate, about the thickness of a crown-piece, and of considerable hardness.

VOL. $1 \mathrm{~V}$. 
This plate of course exhibits concentric circles, somewhat similar to the annual circles in the cross section of a tree. In the same manner she proceeds till she has completed ten or twelve cells ; and then she closes the main entrance with a barrier of smilar materials.

Let us compare the progress of this little joiner with a human artisan-one who has been long practiced in his trade, and has the most perfect and complicated tools for his assistance. The bee has learnt nothing by practice; she makes her nest but once in her life, but it is then as complete and finished as if she had made a thousand. She has no pattern before herbut the Architect of all things has impressed a plan upon her mind, which she can realize without scale or compasses. Her two sharp teeth are the only tools with which she is provided for her laborious work; and yet she bores a tunnel, twelve times the length of her own body, with greater ease than the workman who bores into the earth for water, with his apparatus of augurs adapted to every soil. Her tunnel is clean and regular; she leaves no chips at the bottom, for she is provident of her materials. Further, she has an exquisite piece of joinery to perform, when her ruder labour is accomplished. The patient bee works her rings from the circumference to the centre, and she produces a shelf, united with such care with her natural glue, that a number of fragments are as solid as one piece.

The violet carpenter-bee, as may be expected, occupies several weeks in these complicated labours; and during that period she is gradually depositing her eggs, each of which is successively to become a grub, a pupa, and a perfect bee. It is obvious, therefore, as she does not lay all her eggs in the same place-as each is separated from the other by a laborious process-that the egg which is first laid will be the earliest hatched; and that the first perfect 
insect, being older than its fellows in the same tunnel, will strive to make its escape sooner, and so on of the rest. The careful mother provides for this contingency. She makes a lateral opening at the bottom of the cells; for the teeth of the young bees would not be strong enough to pierce the outer wood, though they can remove the cemented rings of sawdust in the interior. Réaumur observed these holes, in several cases; and he further noticed another external opening opposite to the middle cell, which he supposed was formed, in the first instance, to shorten the distance for the removal of the fragments of wood in the lower half of the building.

That bees of similar habits, if not the same species as the violet bee, are indigenous to this country, is proved by Grew, who mentions, in his 'Rarities of Gresham College,' having found a series of such cells in the middle of the pith of an old elder branch, in which they were placed lengthwise, one after another, with a thin boundary between each. As he does not, however, tell us that he was acquainted with the insect which constructed these, it might as probably be allied to the Ceratina albilabris, of which Spinola has given so interesting an account in the 'Annales du Musíum d'Histoire Naturelle' (x. 236). This noble and learned naturalist tells us, that one evening he perceived a female ceratina alight on the branch of a bramble, partly withered, and of which the extremity had been broken; and, after resting a moment, suddenly disappear. On detaching the branch, he found that it was perforated, and that the insect was in the very act of excavating a nidus for her eggs. He forthwith gathered a bundle of branches, both of the bramble ard the wild-rose, similarly perforated, and took them home to examine them at leisure. Upon inspection, he 
found that the nests were furnished, like those of the same tribe, with balls of pollen kneaded with honey, as a provision for the grubs.

The female ceratina selects a branch of the bramble or wild-rose which has been accidentally broken, and digs into the pith only, leaving the wood and bark untouched. Her mandibles, indeed, are not adapted for gnawing wood; and, accordingly, he found instances in which she could not finish a nest in branches of the wild-rose, where the pith was not of sufficient diameter.

The insect usually makes her perforation a foot in depth, and divides this into eight, nine, or even twelve cells, each about five lines long, and separated by partitions formed of the gnawings of the pith, cemented by honey, or some similar glutinous fluid, much in the same manner with the xylocopa violacea, which we have already described.

\section{Carpenter-W asps.}

As there are mason-wasps similar in economy to mason-bees, so are there solitary carpenter-wasps which dig galleries in timber, and partition them out into several cells by means of the gnawings of the wood which they have detached. This sort of wasp is of the genus Eumenes. The wood selected is generally such as is soft, or in a state of decay; and the hole which is dug in it is much less neat and regular than that of the carpenter-bees, while the division of the chambers is nothing more than the rubbish produced during the excavation.

The provision which is made for the grub consists of flies or gnats piled into the chamber, but without the nice order remarkable in the spiral columns of green caterpillars provided by the mason-wasp (Odinerus murarius). The most remarkable circumstance is, that in some of the species, when the 


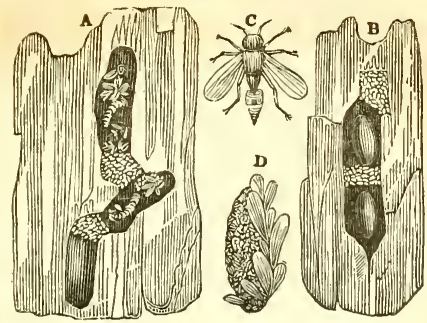

A B represent sections of old wooden posts, with the cells of the carpenter-wasp. In fig. $\mathbf{A}$ the young grubs are shewn feeding on the insects placed there for their support by the parent wasp. The cells in fig. $\mathrm{B}$ contains cocoons. C. carpenter-wasp, natural size. D, cocoon of a carpenter-wasp, composed of sawdust and wings of insects.

grub is about to go into the pupa state, it spins a case (a cocoon), into which it interweaves the wings of the flies whose bodies it has previously devoured. In other species, the gnawings of the wood are employed in a similar manner.

\section{UPhOLSTERER-BEes.}

In another part of this volume we shall see how certain caterpillars construct abodes for themselves, by cutting off portions of the leaves or bark of plants, and uniting them by means of silk into a uniform and compact texture; but this scarcely appears so wonderful as the prospective labours of some species of bees for the lodgment of their progeny. We allude to the solitary bees, known by the name of the leaf-cutting bees, but which may be denominated more generally upholsterer-bees, as there are some of them which use other materials besides leaves.

VOL. IV. 
One species of our little upholsterers has been called the poppy-bee (Osmia papaveris, LATr.), from its selecting the scarlet petals of the poppy as tapestry for its cells. Kirby and Spence express their doubts whether it is indigenous to this country: we are almost certain that we have seen the nests in Scotland.* At Largs, in Ayrshire, a beautiful sea-bathing village on the Frith of Clyde, in July, 1814, we found in a foot-path a great number of the cylindrical perforations of the poppybee. Réaumur remarked that the cells of this bee which he found at Bercy, were situated in a northern exposure, contrary to what he had remarked in the mason-bee, which prefers the south. The cells at Largs, however, were on an elevated bank, facing the south, near Sir Thomas Brisbane's observatory. With respect to exposure, indeed, no certain rule seems applicable; for the nests of masonbees which we found on the wall of Greenwich Park faced the north-east, and we have often found carpenter-bees make choice of a similar situation. In one instance, we found carpenter-bees working indifferently on the north-east and south-west side of the same post.

As we did not perceive any heaps of earth near the holes at Largs, we concluded that it must either have been carried off piecemeal when they were dug, or that they were old holes re-occupied,- - (a circumstance common with bees), and that the rubbish had been trodden down by passengers. Réaumur, who so minutely describes the subsequent operations of the bee, says nothing respecting its excavations. One of these holes is about three inches deep, gradually widening as it descends, till it assumes the form of a small Florence flask. 'The interior of this is rendered smooth, uniform, and polished, in orcler 
to adapt it to the tapestry with which it is intended to be hung, and which is the next step in the process.

The material used for tapestry by the insect upholsterer is supplied by the petals* of the scarlet fieldpoppy, from which she successively cuts off small pieces of an oval shape, seizes them between her legs, and conveys them to the nest. She begins her work at the bottum, which she overlays with three or four leaves in thickness, and the sides have never less than two. When she finds that the piece she has brought is too large to fit the place intended, she cuts off what is superfluous, and carries away the shreds. By cutting the fresh petal of a poppy with a pair of scissors, we may perceive the difficulty of keeping the piece free from wrinkles and shrivelling; but the bee knows how to spread the pieces which she uses as smooth as glass.

When she has in this manner hung the little chamber all round with this splendid scarlet tapestry, of which she is not sparing, but extends it even beyond the entrance, she then fills it with the pollen of flowers mixed with honey, to the height of about half an inch. In this magazine of provisions for her future progeny she lays an egg, and over it folds down the tapestry of poppy petals from above. The upper part is then filled in with earth; but Latreille says, he has observed more than one cell constructed in a single excavation. This may account for Réaumur's describing them as sometimes seven inches deep; a circumstance which Latreille, however, thinks very surprising.

It will, perhaps, be impossible ever to ascertain, beyond a doubt, whether the tapestry-bee is led to

* Petal is the term employed by botanists to denote the leaf, or division of the coloured portion of a flower. 
select the brilliant petals of the poppy from their colour, or from any other quality they may possess, of softness or of warmth, for instance. Réaumur thinks that the largeness, united with the flexibility of the poppy-leaves, determines her choice. Y $\mathrm{Y}$ it is not improbable that her eye may be gratified by the appearance of her nest;- that she may possess a feeling of the beautiful in colour, and may look with complacency upon the delicate hangings of the apartment which she destines for her offspring. Why should not an insect be supposed to have a glimmering of the value of ornament ? How can we pronounce, from our limited notion of the mode in which the inferior animals think and act, that their gratifications are wholly bounded by the positive utility of the objects which surround them? Why does a dog lowl at the sound of a bugle, but because it offends his organs of hearing?-and why, therefore, may not a bee feel gladness in the brilliant hues of her scarlet drapery, because they are grateful to her organs of sight? All these little creatures work, probably, with more neatness and finish than is absolutely essential for comfort; and this circumstance alone would imply that they have something of taste to exhibit, which produces to them a pleasurable emotion.

The tapestry-bee is, however, content with ornamenting the interior only of the nest which she forms for her progeny. She does not misplace her cmbellishments with the error of some human artists. She desires security as well as elegance; and, therefore, she leaves no external traces of her operations. Her's is not a mansion rich with columns and friezes without, but cold and unfurnished within, like the desolate palaces of Venice. She covers her tapestry quite round with the common earth; and leaves her eggs enclosed in their poppy-case with a ccrtainty 
that the outward shew of her labours will attract no plunderer.

The poppy-bee may be known by its being rather more than a third of an inch long, of a black colour, studded on the head and back with reddish grey hairs; the belly being grey and silky, and the rings margined with grey above, the second and third having an impressed transversal line.

A species of solitary bee (Anthidium manicatum, Fabricius), by no means uncommon with us, forms a nest of a peculiarly interesting structure. Kirby and Spense say, that it does not excavate holes, but makes choice of the cavities of old trees, key-holes, and similar localities; yet it is highly probable, we think, that it may sometimes scoop out a suitable cavity when it cannot find one; for its mandibles seem equally capable of this, with those of any of the carpenter or mason bees.

Be this as it may, the bee in question having selected a place suitably sheltered from the weather, and from the intrusion of depredators, proceeds to form her nest, the exterior walls of which she forms of the wool of pubescent plants, such as rose-campion (Lychnis coronaria), the quince (Pyrus cydonia), cats-ears (Stachys lanata), \&c. "It is very pleasant," says Mr White of Selborne, "to see with what address this insect strips off the down, running from the top to the bottom of the branch, and shaving it bare with all the dexterity of a hoop shaver. When it has got a vast bundle, almost as large as itself, it flies away, holding it secure between its chin and its fore-legs." "**

The manner in which the cells of the nest are

*Naturalist's Calender, p. 109. 
made seems not to be very clearly understood. M. Latreille says, that after constructing her nest of the down of quince leaves, she deposits her eggs, together with a store of paste, formed of the pollen of flowers, for nourishing the grubs. Kirby and Spense, on the other hand, tell us, that " the parent bee, after having constructed her cells, laid an egg in each, and filled them with a store of suitable food, plasters them with a covering of vermiform masses, apparently composed of honey and pollen; and having done this, aware, long before Count Rumford's experiments, what materials conduct heat most slowly," she collects the down from woolly plants, and "sticks it upon the plaster that covers her cells, and thus closely envelopes them with a warm coating of down, impervious to every change of temperature." "From later observations," however, they are "inclined to think that these cells may possibly, as in the case of the humble-bee, be in fact formed by the larva previously to becoming a pupa, after having eaten the provision of pollen and honey with which the parent bee had surrounded it. The vermicular shape, however, of the masses with which the cases are surrounded, does not seem easily reconcileable with this supposition, unless they are considered as the excrement of the larva."

Whether or not this second explanation is the true one, we have not the means of ascertaining; but we are almost certain the first is incorrect, as it is contrary to the regular procedure of insects, to begin with the interior part of any structure, and work outwards. We should imagine, then, that the down is first spread out into the form required, and afterwards plastered on the inside to keep it in form, when pro-

* Introduction to Entomology, vol. i. p. 435, 5th edit. 
bably the grub spins the vermicular cells previous to its metamorphosis.

It might prove interesting to investigate this more minutely; and, as the bee is by no means scarce in the neighbourhood of London, it might not be difficult for a careful observer to witness all the details of this singular architecture. The bee may be readily known from its congeners, by its being about the size of the hive-bee, but more broad and flattened, blackish brown above, with a row of six yellow or white spots along each side of the rings, very like the roseleaf cutter, and having the belly covered with yellowish brown hair, and the legs finged with long hairs of a rather lighter colour.

A common bee belonging to the family of upholsterers is called the rose-leaf cutter (Megachile centuncularis, LATr.) The singularly ingenious habits of this bee have long attracted the attention of naturalists, but the most interesting description is given by Réaumur. So extraordinary does the construction of their nests appear, that a French gardener having dug up some, and believing them to be the work of a magician, who had placed them in his garden with evil intent, sent them to Paris to his master, for advice as to what should be done by way of exorcism. On applying to the Abbé Nollet, the owner of the garden was soon persuaded that the nests in question were the work of insects; and M. Réaumur, to whom they were subsequently sent, found them to be the nests of one of the upholsterer-bees, and probably of the rose-leaf cutter, though the nests in question were made of the leaves of the mountain-ash (Pyrus aucuparia.)

The rose-leaf cutter makes a cylindrical hole in a beaten pathway, for the sake of more consolidated earth, (or in the cavities of walls or decayed wood,) 
from six to ten inches deep, and does not throw the earth dug out from it into a heap, like the andrenæ.* In this she constructs several cells about an inch in length, shaped like a thimble, and made of cuttings of leaves (not petals), neatly folded together, the bottom of one thimble-shaped cell being inserted into the mouth of the one below it, and so on in succession.

It is interesting to observe the manner in which this bee procures the materials for forming the tapestry of her cells. The leaf of the rose-tree seems to be that which she prefers, though she sometimes takes other sorts of leaves, particularly those with serrated margins, such as the birch, the perennial mercury (Mercurialis perennis), mountain ash, \&c. She places herself upon the outer edge of the leaf which she has selected, so that its margin may pass between her legs. 'Turning her head towards the point, she commences near the footstalk, and with her mandibles cuts out a circular piece with as much expedition as we could do with a pair of scissors, and with more accuracy and neatness than could easily be done by us. As she proceeds, she keeps the cut portion between her legs so as not to impede her progress; and using her body for a trammel, as a carpenter would say, she cuts in a regular curved line. As she supports herself during the operation upon the portion of the leaf which she is detaching, it must be obvious, when it is nearly cut off, that the weight of her body might tear it away, so as to injure the accuracy of its curvilineal shape. To prevent any accident of this kind, as soon as she suspects that her weight might tear it, she poises herself on her wings, till she has completed the incision. It has been said, by naturalists, that this manœuvre of poising 
herself on the wing, is to prevent her falling to the ground, when the piece gives way; but as no winged insect requires to take any such precaution, our explanation is probably the true one.

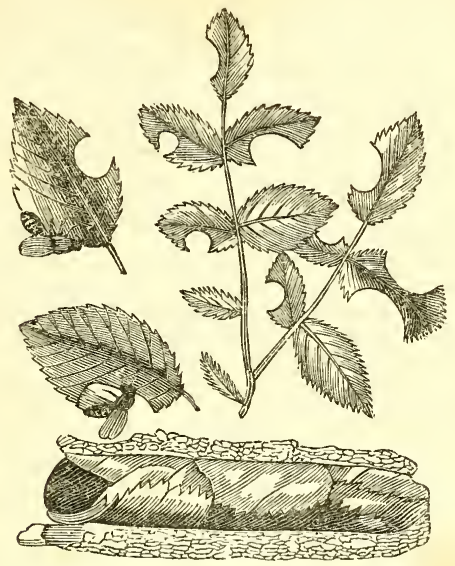

Rose leaf-cutter bees, and nest lined with rose-leaves.

With the piece which she has thus cut out, held in a bent position perpendicular to her body, she flies off to her nest, and fits it into the interior with the utmost neatness and ingenuity; and, without employing any paste or glue; the trusts, as Réaumur ascertained, to the spring the leaf takes, in trying to retain it in its position. It requires from nine to twelve pieces of leaf to form one cell, as they are not always of pre

$$
\text { vor. IV. }
$$


cisely the same thickness. The interior surface of each cell consists of three pieces of leaf, of equal size, narrow at one end, but gradually widening at the other, where the width equals half the length. One side of each of the pieces is the serrated margin of the leaf from which it was cut, and this margin is always placed outermost, and the cut margin innermost. Like most insects, she builds from the interior, beginning with a layer of tapestry, which is composed of three or four oval pieces, larger in dimensions than the rest, adding a second and a third layer proportionately smaller. In forming these, she is careful not to place a joining opposite to a joining, but with all the skill of a consummate artificer, lays the middle of each piece of leaf over the margins of the others, so as by this means both to cover and strengthen the junctions. By repeating this process, she sometimes forms a fourth or fifth layer of leaves, taking care to bend the leaves at the narrow extremity or closed end of the cell, so as to bring them into a convex shape.

When she has in this manner completed a cell, her next business is to replenish it with a store of honey and pollen, which, being chiefly collected from thistles, forms a beautiful rose-coloured conserve. In this she deposites a single egg, and then covers in the opening with three pieces of leaf, so exactly circular, that a pair of compasses could not define their nuargin with more accuracy. In this manner the industrious and ingenious upholsterer proceeds till the whole gallery is filled, the convex extremity of the one fitting into the open end of the next, and serving both as a basis and as the means of strengthening it. If, by any accident, the labour of these insects is interrupted or the edifice deranged, they exhibit astonishing perseverance in setting it again to rights. 
Insects, indeed, are not easily forced to abandon any work which they may have begun.

The monkish legends tell us that St Francis Xavier, walking one day in a garden, and seeing an insect of the Mantis genus, moving along in its solemn way, holding up its two fore legs as in the act of devotion, desired it to sing the praises of God. The legend adds that the saint immediately heard the insect carol a fine canticle with a loud emphasis. We want no miraculous voice to record the wonders of the Almighty hand, when we regard the insect world. The little rose-leaf cutter, pursuing her work with the nicest mathematical art-using no artificial instruments to form her ovals and her circles-knowing that the elastic property of the leaves will retain them in their position-making her nest of equal strength throughout, by the most rational adjustment of each distinct part-demands from us something more than mere wonder; for such an exercise of instinctive ingenuity at once directs our admiration to the great Contriver, who has so admirably pro portioned her knowledge to her necessities. 


\section{Chapter IV}

\section{Carder-Bees; Humble-Bees; Social-Wasps.}

THE bees and wasps, whose ingenious architecture we have already examined, are solitary in their labours. Those we are about to describe live in society. The perfection of the social state among this class of insects is certainly that of the hive-bees. They are the inhabitants of a large city, where the arts are carried to a higher excellence than in small districts, enjoying little communication of intelligence. But the bees of the villages, if we may follow up the parallel, are not without their interest. Such are those which are called carder-bees and humble bees.

\section{Carder-Bees.}

The nests of the bees which Réaumur denominates carders (Bombus muscorum, LATr.), are by no means uncommon, and are well worth the study of the naturalist. During the hay harvest, they are frequently met with by mowers in the open fields and meadows; but they may sometimes be discovered in hedge-banks, the borders of copses, or among mossgrown stones. The description of the mode of building adopted by this bee has been copied by most of our writers on insects from Réaumur; though he is not a little severe on those who write, without having ever had a single nest in their possession. We have been able to avoid such a reproach; for we have now before 
us a very complete nest of carder-bees, which differs from those described by $\mathbf{R}$ : aumur, in being made, not of moss, but withered grass. With this exception, we find that his account agrees accurately with our own observation.*

The carder-bees select for their nest a shallow excavation about half a foot in diameter; but when they cannot find one to suit their purpose, they undertake the Herculean task of digging one themselves. They cover this hollow with a dome of moss-sometimes, as we have ascertained, of withered grass. 'They make use, indeed, of whatever materials may be within their reach; for they do not attempt to bring any thing from a distance, not even when they are deprived of the greater portion by an experimental naturalist. Their only method of transporting materials to the building is by pushing them along the ground-the bee, for that purpose, working backwards, with its head turned from the nest. If there is only one bee engaged in this labour, as usually happens in the early spring, when a nest is founded by a solitary female who has outlived the winter, she transports her little bundles of moss or grass by successive backward pushes, till she gets them home.

In the latter part of the season, when the hive is populous and can afford more hands, there is an ingenious division of this labour. A file of bees, to the number sometimes of half a dozen, is established, from the nest to the moss or grass which they intend to use, the heads of all the file of bees being turned from the nest and towards the material. The last bee of the file lays hold of some of the moss with her mandibles, disentangles it from the rest, and having carded it with her fore-legs iuto a sort of felt or small bundle, she pushes it under her body to the

*J. $\mathbf{R}$.

voL. IV. 
next bee, who passes it in the same manner to the next, and so on till it is brought to the border of the nest,-in the same way as we sometimes see sugarloaves conveyed from a cart to a warehouse, by a file of porters throwing them from one to another.

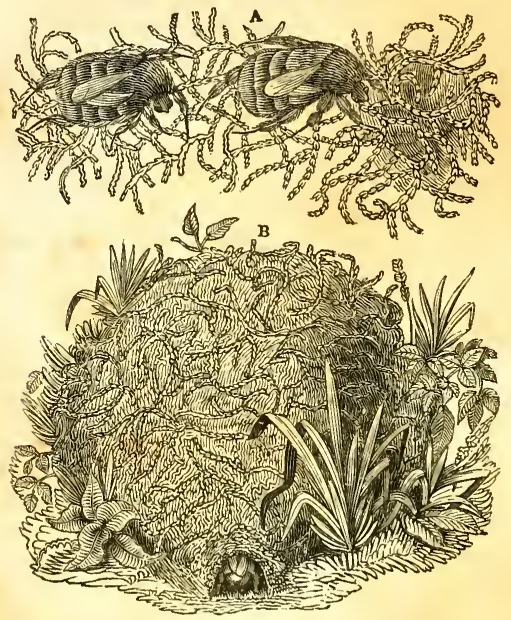

Fig. A represents two carder-bees heckling moss for their nests. $B$, exterior view of the nest of the carder-bee.

The elevation of the dome, which is all built from the interior is, from four to six inches above the level of the field. Beside the moss or grass, they frequently employ coarse wax to form the ceiling of the vault, for the purpose of keeping out rain, and 
preventing high winds from destroying it. Before this finishing is given to the nest, we have remarked, that on a fine sunshiny day, the upper portion of the dome was opened to the extent of more than an inch, in order, we suppose, to forward the hatching of the eggs in the interior; but on the approach of night this was carefully covered in again. It was remarkable that the opening which we have just mentioned was never used by the bees for either their entrance or their exit from the nest, though they were all at work there, and, of course would have found it the readiest and easiest passage. But they invariably made their exit and their entrance through the covert-way or gallery which opens at the bottom of the nest, and in some nests, is about a foot long and half an inch wide. This is, no doubt, intended for concealment, from field-mice, polecats, wasps, and other depredators.

On removing a portion of the dome and bringing the interior of the structure into view, we find little of the architectural regularity so conspicuous in the combs of a common bee-hive: instead of this symmetry, there are only a few egg-shaped, dark-coloured cells, placed somewhat irregularly, but approaching more to the horizontal than to the vertical position, and connected together with small amorphus* columns of brown wax. Sometimes there are two or three of these oval cells placed one above anuther, without anything to unite them.

These cells are not, however, the workmanship of the old bees, but of their young grubs, who spin them when they are about to change into nymphs. But, from these cases, when they are spun, the enclosed insects have no means of escaping, and they depend for their liberation on the old bees gnawing 
off the covering, as is done also by ants in the same circumstances. The instinct with which they know the precise time when it is proper to do this is truly wonderful. It is no less so, that these cocoons are by no means useless when thus untenanted, for they subsequently serve for honey-pots, and are indeed the only store-cells in the nest. For this purpose the edge of the cell is repaired and strengthened with a ring of wax.
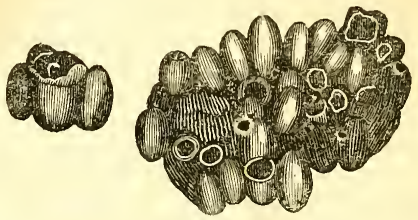

Breeding Cells.

'The true breeding-cells are contained in several amorphus masses of brown-coloured wax, varying in dimensions, but of a somewhat flat and globular shape. On opening any of these, a number of eggs or grubs are found, on whose account the mother bee has collected the masses of wax, which also contain a supply of pollen moistened with honey, for their subsistence.

The number of eggs or grubs found in one spheroid of wax varies from three to thirty, and the bees in a whole nest seldom exceed sixty. There are three sizes of bees, of which the females are the largest; but neither these nor the males are, as in the case of the hive-bee, exempt from labour. The females, indeed, always found the nests, since they alone survive the winter, all the rest perishing with cold. In each nest, also, are several females, that live in harmony together. 


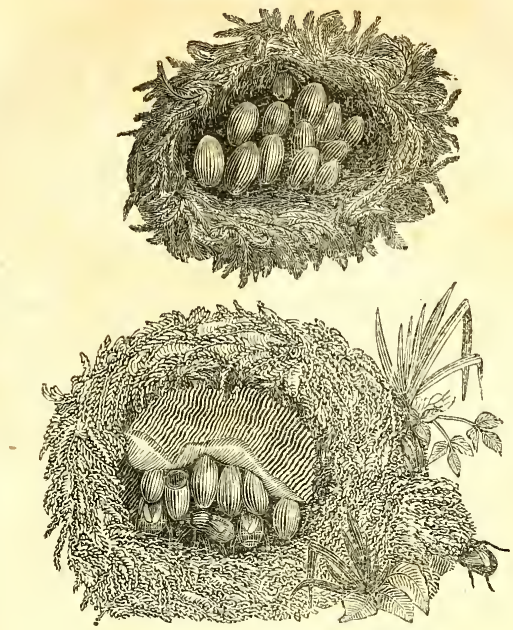

Interior views of Carder-bee's Nest.

The carder-bees may be easily distinguished from their congeners (of the same genus), by being not unlike the colour of the withered moss with which they build their nests, having the fore part of their back a dull orange, and hinder part ringed with different shades of greyish yellow. They are not so large as the common humble-bee (Bombus terresiris, LATR). but rather shorter and thicker in the body than the common hive-bee (Apis mellifica.) 


\section{Lapidary-BeEs.}

A bee still more common, perhaps, than the carder, is the orange-tailed bee, or lapidary (Bombus lapidaria), readily known by its general black colour and reddish orange tail. It builds its nest sometimes in stony ground, but prefers a heap of stones such as are gathered off grass fields, or are piled up near quarries. Unlike the carder, the lapidary carries to its nest bits of moss, which are very neatly arranged into a regular oval. These insects associate in their labours; and they make honey with great industry. The individuals of a nest are more numerous than the carders, and likewise more pertinaciously vindictive. About two years ago, we discovered a nest of these bees at Compton-Basset, in Wiltshire, in the centre of a heap of limestone rubbish; but owing to the brisk defensive warfare of their legionaries, we could not obtain a view of the interior. It was not even safe to approach within many yards of the place, and we do not exaggerate when we say that several of them pursued us most pertinaciously about a quarter of a mile.**

\section{Humble Bees.}

The common humble-bee (Bombus terrestris) is preciscly similar in its economy to the two preceding spceies, with this difference, that it forms its nest underground like the conmon wasp, in an excavated chaniber, to which a winding passage leads, of from one to two fect, and of a diameter sufficient to allow of two bees passing. The cclls have no covering besite the vault of the excavation and patches of coarse wax sinilar to that of the carder-bee. 


\section{Social Wasps.}

The nest of the common wasp (Vespa vulgaris) attracts more or less the attention of every body; but its interior architecture is not so well known as it deserves to be, for its singular ingenuity, in which it rivals even that of the hive-bee (Apis mellifica). In their general economy, the social, or republican wasps, closely resemble the humble-bee (Bombus), every colony being founded by a single female who has survived the winter, to the rigours of which all her summer associates of males and working wasps uniformily fall victims. Nay, out of three hundred females which may be found in one vespiary, or wasp's nest, towards the close of autumn, scarcely ten or a dozen survive till the ensuing spring, at which season they awake from their hybernal lethargy, and begin with ardour the labours of colonization.

It may be interesting to follow one of these mother wasps through her several operations, in which she merits more the praise of industry than the queen of a bee-hive, who does nothing, and never moves without a numerous train of obedient retainers, always ready to execute her commands, and to do her homage. The mother wasp, on the contrary, is at first alone, and is obliged to perform every species of drudgery herself.

Her first care, after being roused to activity by the returning warmth of the season, is to discover a place suitable for her intended colony; and, accordingly, in the spring, wasps may be seen prying into every hole of a hedge bank, particularly where field-mice have burrowed. Some authors report that she is partial to the forsaken galleries of the mole, but this does not ar.cord with our observations, as we have never met with a single vespiary in any situation likely to have been frequented by moles 
But though we eannot assert the fact, we think it highly probable that the deserted nest of the fieldmouse, which is not uncommon in hedge banks, may be sometimes appropriated by a mother wasp as an excavation convenient for her purpose. Yet, if she does make choice of the burrow of a field-mouse, it requires to be afterwards considerably enlarged in the interior chamber, and the entrance gallery very much narrowed.

The desire of the wasp to save herself the labour of excavation, by forming her nest where other animals have burrowed, is not without a parallel in the aetions of quadrupeds, and even of birds. In the splendid continuation of Wilson's American Ornithology, by Charles L. Bonaparte (whose scientific pursuits have thrown around that name a beneficent lustre, pleasingly contrasted with his uncle's glory), there is an interesting example of this instinctive adoption of the labours of others. "In the transMississippian territories of the Unitcd States, the burrowing-owl resides exelusively in the villages of the marmot, or prairie dog, whose excavations are so commodious, as to render it unnccessary that the owl should dig for himself, as he is said to do where no burrowing animals exist.* The villages of the prairie $\operatorname{dog}$ are very numerous and variable in their extent,- - sometmes eovering only a few acres, and at others spreading over the surface of the country for miles together. They are composed of slightly elevated mounds, having the form of a truncated cone, about two feet in width at the base, and seldom rising as high as eighteen inches from the surface of the soil. The

* The owl observed by Vipillot in $\mathrm{St}$ Domingo digs itself a burrow two feet in depth, at the bottom of which it deposits its eggrs upon a hed of moss. 
entrance is placed either at the top or on the side, and the whole mound is beaten down externally, especially at the summit, resembling a much-used footpath. From the entrance, the passage into the mound descends vertically for one or two feet, and is thence continued obliquely downwards until it terminates in an apartment, within which the industrious prarie-dog constructs, on the approach of cold weather, a comfortable cell for his winter's sleep. The cell, which is composed of fine dry grass, is globular in form, with an opening at top, capable of admitting the finger; and the whole is so firmly compacted, that it might, without injury, be rolled over the floor." *

In case of need the wasp is abundantly furnished by nature with instruments for excavating a burrow out of the solid ground; as she no doubt most commonly does,-digging the earth with her strong mandibles, and carrying it off or pushing it out as she proceeds. The entrance-gallery is about an inch or less in diameter, and usually runs in a winding or zigzag direction, from one to two feet in depth. In the chamber to which this gallery leads, and which, when completed, is from one to two feet in diameter, the mother wasp lays the foundations of her city, beginning with the walls.

The building materials employed by wasps were long a matter of conjecture to scientific inquirers; for the bluish-grey papery substance of the whole structure has no resemblance to any sort of wax employed by bees for a similar purpose. Now that the discovery has been made, we can with difficulty bring ourselves to believe that a naturalist so acute and indefatigable as M. Rèaumur should have, for twenty years, as he tells us, endeavoured, without success,

* American Ornithology, by Charles Lucien Bonaparte. Vol. i. p. 69 .

voL. IV. 
to find out the secret. At length, however, his perseverance was rewarded. He remarked a female wasp alight on the sash of his window, and begin to gnaw the wood with her mandibles; and it struck him at once that she was procuring materials for building. He saw her detach from the wood a bundle of fibres about a tenth of an inch in length, and finer than a hair; and as she did not swallow these, but gathered them into a mass with her feet, he could not doubt that his first idea was correct. In a short time she shifted to another part of the window-frame, carrying with her the fibres she had collected, and to which she continued to add, when he caught her, in order to examine the nature of her bundle; and he found that it was not yet moistened nor rolled into a ball, as is always done before employing it in building. In every other respect it had precisely the same colour and fibrous texture as the walls of a vespiary. It struck him as remarkable that it bore no resemblance to wood gnawed by other insects, such as the goat-moth caterpillar, which is granular like sawdust. This would not have suited the design of the wasp, who was well aware that fibres of some length form a stronger texture. He even discovered, that before detaching the fibres, she bruised them (les charpissoit) into a sort of lint (charpie) with her mandibles. All this the careful naturalist imitated by bruising and paring the same wood of the window-sash with his pen-knife, till he succeeded in making a little bundle of fibres scarcely to be distinguished from that collected by the wasp..

We have ourselves frequently seen wasps employed in procuring their materials in this manner, and have always observed that they shift from one part to another more than once in preparing a single load,-a circumstance which we ascribe entirely to 
the restless temper peculiar to the whole order of hymenopterous insects. Reaumur found that the wood which they preferred was such as had been long exposed to the weather, and is old and dry. White of Selborne, and Kirby and Spence, on the contrary, maintain that wasps obtain their paper from sound timber, hornets only from that which is decayed.* Our own observations, however, confirm the statement of Réaumur, with respect to wasps, as, in every instance which has fallen under our notice, the wood selected was very much weathered; and in one case an old oak post in a garden at Lee, in Kent, half destroyed by dry-rot, was seemingly the resort of all the wasps in the vicinity. In another case, the deal bond in a brick wall, which had been built thirty years, is at this moment (June, 1829) literally striped with the gnawings of wasps, which we have watched at the work for hours together. $\dagger$

The bundles of ligneous fibres thus detached, are moistened, before being used, with a glutinous liquid, which causes them to adhere together, and are then kneaded into a sort of paste, or papicr maché. Having prepared some of this material, the mother wasp begins first to line with it the roof of her chamber, for wasps always build downwards. The round ball of fibres which she has previously kneaded up with glue, she now forms into a leaf, walking backwards, and spreading it out with her mandibles, her tongue, and her feet, till it is as thin almost as tissue paper.

One sheet, however, of such paper as this would form but a fragile ceiling, quite insufficient to prevent the earth from falling down into the nest. The wasp, accordingly, is not satisfied with her work

* Rèaumur, vol. vi. bottom of page 182 ; Hist. of Selb. ii 228 ; and Introd. to Entomol. i. 50.4, 5th edition. 
till she has spread fifteen or sixteen layers one above the other, rendering the wall altogether nearly two inches thick. The several layers are not placed in contact like the layers of a piece of pasteboard, but with small intervals or open spaces between, appearing somewhat like a grotto built with bivalve shells, particularly when looked at on the outside. This is probably eaused by the insect working in a curvilineal manner.

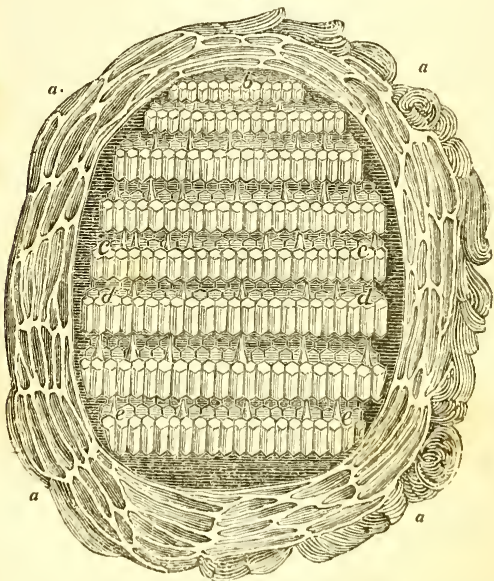

Section of the Social-Wisp's . Vicst.- $a$ a, the external wall ; $b, c c$, five small terraces of eells for the ncuter wasps; $d d, c c$, three rows of larger cells for the inales and lemales.

Having finished the cciling, she next begins to build the first terrace of her eity, which, under its 
protection, she suspends horizontally, and not like the combs in a bee-hive, in a perpendicular position. The suspension of which we speak is also light and elegant, compared with the more heavy union of the hive-bees' combs. It is in fact a hanging floor, immoveably secured by rods of similar materials with the roof, but rather stronger. From twelve to thirty of these rods, about an inch or less in length, and a quarter of an inch in diameter, are constructed

A

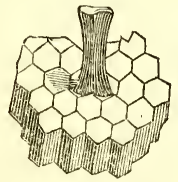

$\mathrm{B}$

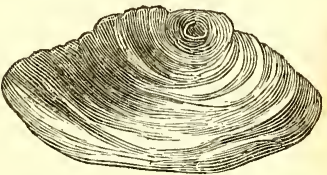

A, represents one of the rools from which the terraces are suspended $B$, a portion of the external crust.

for the suspension of the terrace. They are elegant in form, being made gradually narrower towards the middle, and widening at each end, in order, no doubt, to render their hold the stronger.

The terrace itself is circular, and composed of an immense number of cells, formed of the paper already described, and of almost the same size and form as those of a honey-comb, each being a perfect hexagon, mathematically exact, and every hair's breadth of the space completely filled. These cells, however, are never used as honey-pots by wasps, as they are by bees; for wasps make no honey, and the cells are wholly appropriated to the rearing of their young. Like other hymenopterous insects, the grubs are placed with their heads downwards; and the openings of the cells are also downwards: while NOL, IV 
their united bottoms form a nearly uniform level upon which the inhabitants of the nest may walk. IVe have seen, in describing the economy of the carder-bee, that when a young bee had escaped from its cradle-cell, and so rendered it empty, that cell was subsequently appropriated to the storing of honey. But in the case of wasps, a cell thus evacuated is immediately cleaned out and repaired for the reception of another grub-an egg being laid in it by a female wasp as soon as it is ready.

When the foundress wasp has completed a certain number of cells, and deposited eggs in them, she soon intermits her building operations, in order to procure food for the young grubs, which now require all her care. In a few weeks these become perfect wasps, and lend their assistance in the extension of the edifice; enlarging the original coping of the foundress by side walls, and forming another platform of cells, suspended to the first by columns, as that had been suspended to the ceiling.

In this manner several platforms of combs are constructed, the outer walls being extended at the same time; and, by the end of the summer, there is generally from twelve to fifteen platforms of cells. Each contains about 1060 cells-forty-nine being contained in an inch and a half square, and, of course, making the enormous number of about 16,000 cells in one colony. R'aumur, upon these data, calculates that one vespiary may produce every year more than 30,000 wasps, reckoning only 10,000 cells, and each serving successively for the cradle of three generations. But, although the whole structure is built at the expense of so much labour and ingenuity, it has scarcely been finished before the winter sets in, when it becomes nearly uscless, and serves only for the abode of a few benumbed females, who abandon it on the approach of spring, and never return; for 
wasps do not, like mason-bees, ever make use of the same nest for more than one season.

Both Réaumur and the younger Huber studied the proceedings of the common wasp in the manner which has been so successful in observing bees-by means of glazed hives, and other contrivances. In this, these naturalists were greatly aided by the extrcme affection of wasps for their young; for though their nest is carried off, or even cut in various directions, and exposed to the light, they never desert it, nor relax their attention to their progeny. When a wasp's nest is removed from its natural situation, and covered with a glass hive, the first operation of the inhabitants is to repair the injuries it has suffered. They carry off with surprising activity all the earth or other matters which have fallen by accident into the nest; and when they have got it thoroughly cleared of everything extraneous, they begin to secure it from further derangement, by fixing it to the glass with papyraceous columns, similar to those which we have already described. The breaches which the nest may have suffered are then repaired, and the thickness of the walls is augmented, with the design, perhaps, for more effectually excluding the light.

The nest of the hornet is nearly the same in structure with that of the wasp; but the materials are considerably coarser, and the columns to which the platforms of cells are suspended are larger and stronger, the middle one being twice as thick as any of the others. The hornet, also, does not build under ground, but in the cavities of trees, or in the thatch or under the eaves of barns. Reaumur once found upon a wall a hornet's nest which had not been long begun, and had it transferred to the outside of his study window; but in consequence, 
as he imagined, of the absence of the foundress hornet at the time it was removed, he could not get the other five hornets, of which the colony consisted, either to add to the building or repair the damages which it had sustained.

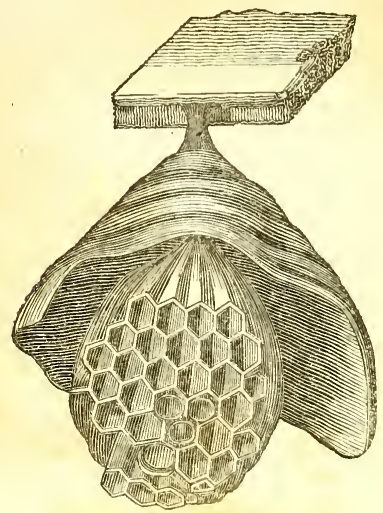

Hornct's nest in its first stagc.

M. Réaumur differs from our English naturalists, White, Kirby, and Spence, with respect to the materials employed by the hornet for building. The latter say that it employs decayed wood; the former, that it uses the bark of the ash-tree, but takes less pains to split it into fine fibres than wasps do; not, however, because it is destitute of skill; for in constructing the suspensory columns of the platforms, a paste is prepared little inferior to that made by wasps. iVe cannot, from our own observations, decide which 
of the above statements is correct, as we have only once seen a hornet procuring materials, at ComptonBasset, in Wiltshire; and in that case it gnawed the inner bark of an elm which had been felled for several months, and was, consequently, dry and tough. Such materials as this would account for the common yellowish-brown colour of a hornet's nest.*

When hornets make choice of a tree for their domicile, they select one which is in a state of decay, and already partly hollowed: but they possess the means, in their sharp and strong mandibles, of extending the excavation to suit their purposes; and Reaumur fiequently witnessed their operations in mining into a decayed tree, and carrying off what they had gnawed. He observed, also, that in such cases they did not make. use of the large hole of the tree for an entrance, but went to the trouble of digging a gallery, sufficient for the passage of the largest hornet in the nest, through the living and undecayed portion of the tree. As this is perforated in a winding direction, it is no doubt intended for the purpose of protecting the nest from the intrusion of depredators, who could more easily effect an entrance if there were not such a tortuous way to pass through.

One of the most remarkable of our native socialwasps is the Vespa britannicu, or tree-wasp, which is not uncommon in the northern, but is seldom to be met with in the southern parts of the island. Instead of burrowing in the ground like the common wasp (Vespa vulgaris), or in the hollows of trees like the hornet (Vespa crabro), it boldly swings its nest from the extremity of a branch, where it exhibits some resemblance, in size and colour, to a Welsh wig, hung out to dry. We have seen more than one of these nestg on the same tree, at Catrine, in Ayrshire, 
and at Wemyss Bay, in Renfrewshire. The tree which the Britannic wasp prefers is the silver fir, whose broad flat branch serves as a protection to the suspended nest both from the sun and the rain. The materials and structure are nearly the same as those employed by the common wasp, and which we have already described.*

A singular nest of a species of wasp is figured by Reaumur, but is apparently rare in this country, as Kirby and Spence mention only a single nest of similar construction, found in a garden at East-Dale. This nest is of a flattened globular figure, and composed of a great number of envelopes, so as to assume a considerable resemblance to a half-expanded Province rose. The British specimen mentioned by Kirby and Spence had only one platform of cells; Réaumur's had two ; but there was a large vacant space, which would probably have been filled with cells, had the nest not been taken away as a specimen. The whole

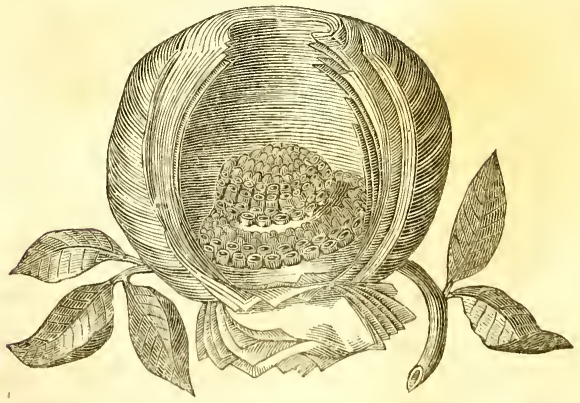

Wusp's $N_{\text {cst. }}$.

J. R. 
nest was not much larger than a rose, and was composed of paper exactly similar to that employed by the common ground-wasp.

There is another species of social-wasp (Epipone nidulans, LATr.) meriting attention from the singular construction of its nest. It forms one or more terraces of cells, similar to those of the common wasp, but without the protection of an outer wall, and quite exposed to the weather. Swammerdam found a nest of this description attached to the stem of a nettle. Réaumur says they are sometimes attached to the branch of a thorn or other shrub, or to stalks of grass; -peculiarities which prove that there are several species of these wasps.

The most remarkable circumstance in the archi-

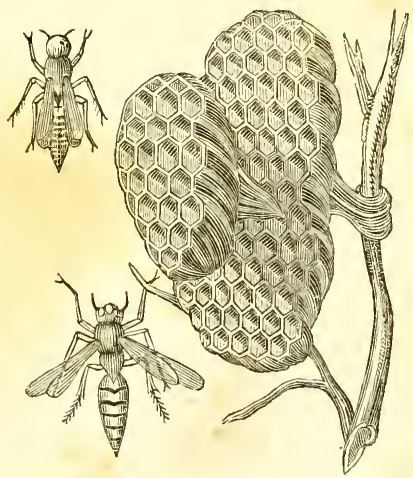

Wasp's Cells attached to a branch. 
tecture of this species of vespiary is, that it is not horizontal, like those formerly described, but nearly vertical. The reason appears to be that if it had been horizontal, the cells must have been frequently filled with rain; whereas, in the position in which it is placed, the rain runs off without lodging. It is, besides, invariably placed so as to face the north or the east, and consequently is less exposed to rains, which most frequently come with southerly or westerly winds. It is another remarkable peculiarity, that unlike the nests of other wasps, it is covered with a shining coat of varnish, to prevent moisture from soaking into the texture of the wasp's paper. The laying on this varnish, indeed, forms a considerable portion of the labour of the colony, and individuals may be seen employed for hours together spreading it on with their tongues.

Few circumstances are more striking with regard to insects, as Kirby and Spence justly remark, than the great and incessant labour which maternal affection for their progeny" leads them to undergo. Some of these exertions are so disproportionate to the size of the insect, that nothing short of ocular conviction could attribute them to such an agent. A wild bee, or a wasp, for instance, as we have seen, will dig a hole in a hard bank of earth some inches deep, and five or six times its own size, labouring unremittingly at this arduous task for several days in succession, and scarcely allowing itself a moment for eating or repose. It will then occupy as much time in searching for a store of food; and no sooner is this finished, than it will set about repeating the process, and before it dies, will have completed five or six similar cells, or even more.

We shall have occasion more particularly to dwel! 
upon the geometrical arrangement of the cells, both of the wasp and the social bee, in our description of those interesting operations, which have long attracted the notice, and commanced the admiration, of mathematicians and naturalists. A few observations may here be properly bestowed upon the material with which the wasp-family construct the interior of their nests.

The wasp is a paper-maker, and a most perfect and intelligent one. While mankind were arriving, by slow degrees, at the art of fabricating this valuable substance, the wasp was making it before their eyes, by very much the same process as that by which human hands now manufacture it with the best aid of chemistry and machinery. While some nations carved their records on wood, and stone, and brass, and leaden tablets, -others, more advanced, wrote with a style on wax, - others employed the inner bark of trees, and others the skins of animals rudely prepared,- - the wasp was manufacturing a firm and durable paper. Even when the papyrus was rendered more fit, by a process of art, for the transmission of ideas in writung, the wasp was a better artisan than the Egyptians; for the early attempts at papermaking were so rude, that the substance produced was almost useless, from being extremely friable. The paper of the papyrus was formed of the leaves of the plant, dried, pressed, and polished; the wasp alone knew how to reduce vegetable fibres to a pulp, and then unite them by a size or glue, spreading the substance out into a smooth and delicate leaf. This is exactly the process of paper-making. It would seem that the wasp knows, as the modern paper-makers now know, that the fibres of rags, whether linen or cotton, are not the only materials that can be used in the formation of paper; she employs other vegetable matters, converting them into VOL. IV. 
a proper eonsistency by her assiduous exertions. In some respects she is more skilful even than ou paper-makers, for she takes care to retain lier fibres of sufficient length, by which she renders her paper as strong as she requires. Many manufacturers of the present day cut their material into small bits, and thus produce a rotten article. One great distinetion between good and bad paper is its toughness; and this indifference is invariably produced by the fibre of which it is composed being long, and therefore tough; or short, and therefore friable.

The wasp has been labouring at her manufacture of paper, from her first creation, with precisely the same instruments and the same materials; and her success has been unvarying. Her machinery is very simple, and therefore it is never out of order. She learns nothing, and she forgets nothing. Men, from time to time, lose their excellence in particular arts, and they are slow in finding out real inprovements. Such improvements are often the effect of accident. Paper is now manufactured very extensively by machinery, in all its stages; and thus, instead of a single sheet being made by hand, a stream of paper is poured out, which would form a roll large enough to extend round the globe, if such a length were desirable. The inventors of this nachinery, Messrs. Fourdrinier, it is said, spent the enormous sum of 40,000l. in vain attempts to render the machine capable of determining with precision the width of the roll; and, at last, accomplished their object, at the suggestion of a bystander, by a strap revolving upon an axis, at a cost of three shillings and sixpence. Such is the differenee between the workings of human knowledge and experience, and those of animal instinct. We proceed slowly and in the dark-but our course is not bounded by a narrow line, for it seems difficult to say what is the per- 
fection of any art; animals go clearly to a given point-but they can go no further. We may, however, learn something from their perfect knowledge of what is within their range. It is not improbable that if man had attended in an earlier state of society to the labours of wasps, he would have sooner known how to make paper. We are still behind in our arts and sciences, because we have not always been observers. If we had watched the operations of insects, and the structure of animals in general, with more care, we might have been far advanced in the knowledge of many arts, which are yet in their infancy, for nature has given us abundance of patterns. IVe have learnt to perfect some instruments of sound, by examining the structure of the human ear; and the mechanism of an eye has suggested some valuable improvements in achromatic glasses.

Réaumur has given a very interesting account of the wasps of Cayenne, which hang their nests in trees.* Like the bird of Africa called the Loxia, they fabricate a perfect house, capable of containing many hundreds of their community, and suspend it on high out of the reach of attack. But the Cayenne wasp is a more expert artist than the bird. $\mathrm{He}$ is a cardmaker;--and travellers of veracity agree that the card with which he forms the exterior covering of his abode is so smooth, so strong, so uniform in its texture, and so white, that the most skilful manufacturer of this substance might be proud of the work.

The nest of the card-making wasp is impervious to water. It hangs upon the branch of a tree, as represented in the engraving; and those rain-drops

" Mémoires sur les Insectes, tom vi., mem. vii. See also Bonnet, vol. ix. 
which penetrate through the leaves never rest upon its hard and polished surface. A small opening for the entrance of the insects terminates its funnelshaped bottom. It is impossible to unite more perfectly the qualities of lightness and strength.

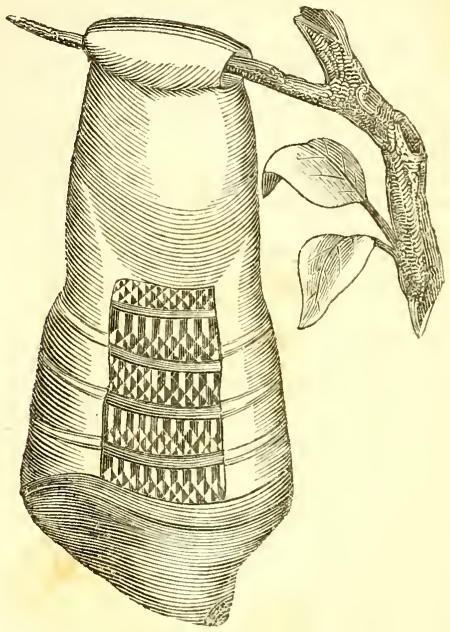

Nest of the Card-maker. Wasp, with part removed to shew the arrangement of the Cells. 


\section{Chapter V.}

Architecture of the Hive-Bee.

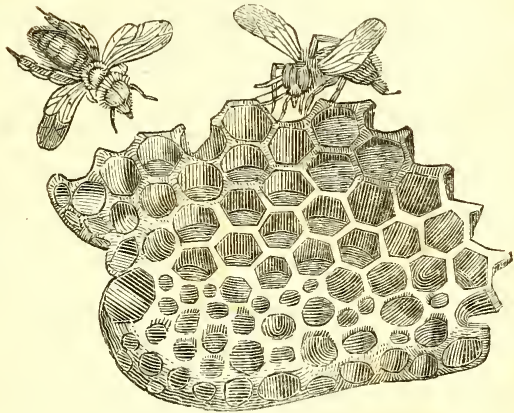

Part of a honcycomb, and bees at work.

Although the hive-bee (Apis mellifica) has engaged the attention of the curious from the earliest ages, recent discoveries prove that we are yet only beginning to arrive at a correct knowledge of its wonderful proceedings. Pliny informs us that Aristomachus, of Soles, in Cilicia, devoted fifty-eight years to the study; and that Philiscus the Thracian spent his whole life in forests for the purpose of observing them. But in consequence (as we may naturally infer) of the imperfect methods of research, asVOL. IV. 
suming that what they did discover was known to Aristotle, Columella, and Pliny, we are justified in pronouncing the statements of these philosophers, as well as the embellished poetical pictures of Virgil, to be nothing more than conjecture, almost in every particular erroneous. It was not indeed till 1712, when glass hives were invented by Maraldi, a mathematician of Nice, that what we may call the in-door proceedings of bees could be observed. This important invention was soon afterwards taken advantage of by M. Réaumur, who laid the foundation of the more recent discoveries of John Hunter, Schirach, and the Hubers. The admirable architecture which bees exhibit in their miniature cities has, by these and other naturalists, been investigated with great care and accuracy. We shall endeavour to give as full an account of their wonderful structures as our limits will allow. In this we shall chiefly follow M. Huber, the elder, whose researches appear almost miraculous when we consider that he was blind.

At the early age of seventeen this remarkable man lost his sight by gutta serena, "the drop serene" of our own Milton. But, though cut off from the sight of Nature's works, he dedicated himself to their study. He saw them through the eyes of the admirable woman whom he married; his philosophical reasonings pointed out to her all that he wanted to ascertain; and as she reported to him from time to time the results of his ingenious experiments, he was enabled to complete, by diligent investigation, one of the most accurate and satisfactory accounts of the habits of bees which has ever been produced. This venerable naturalist is, we believe, still alive.

It had long been known that the bees of a hive consist of three sorts, which were ascertained by 
M. Réaumur to be distinguished as workers or neuters, constituting the bulk of the population; drones or males, the least numerous class; and a single female, the queen and mother of the colony. Schirach subsequently discovered the very extraordinary fact, which Huber and others have proved beyond doubt, that when a hive is accidentalty deprived of a queen, the grub of a worker can be and is fed in a particular manner, so as to become a queen and supply the loss.* But another discovery of MI. Huber is of more importance to the subject of architecture now before us. By minute research he ascertained, that the workers, which had been considered by former naturalists to be all alike, are divided into two important classes, nurse-bees and waxmakers.

The nurse-bees are rather smaller than the waxworkers, and even when gorged with honey their belly does not, as in the others, appear distended. Their business is to collect honey, and impart it to their companions; to feed and take care of the young grubs, and to complete the combs and cells which have been founded by the others; but they are not charged with provisioning the hive.

The wax-workers on the other hand are not only a little larger, but their stomach, when gorged with honey, is capable of considerable distension, as M. Huber proved by repeated experiments. He also ascertained that neither of the species can alone fulfil all the functions shared among the workers of a hive. He painted those of each class with different colours, in order to study their proceedings, and their labours were not interchanged. In another experi-

* It is right to remark that Huish and others have snggested that the grubs thus royalized may originally be misplaced queens; yet this admission is not necessary, since Madlle. Jurine has proved, by dissection, the workers to be imperfect females. 
ment, after supplying a hive deprived of a queen with brood and pollen, he saw the nurse-bees quickly occupied in the nutrition of the grubs, while those of the wax working class neglected them. When hives are full of combs, the wax-workers disgorge their honey into the ordinary magazines, making no wax: but if they want a reservoir for its reception, and if their queen does not find cells ready made wherein to lay her eggs, they retain the honey in the stomach, and in twenty-four hours they produce wax. Then the labour of constructing combs begins.

It might perhaps be supposed that, when the country does not afford honey, the wax-workers consume the provision stored up in the hive. But they are not permitted to touch it. A portion of honey is carefully preserved, and the cells containing it are protected by a waxen covering, which is never removed except in case of cxtreme necessity, and when honey is not to be otherwise procured. The cells are at no time opened during summer; other reservoirs, always exposed, contribute to the daily use of the community; each bee, however, supplying itself from them with nothing but what is required for present wants. Wax-workers appear with large bellies at the entrance of their hive, only when the country affords a copious collection of honey. From this it may be concluded, that the production of the waxy matter depends on a concurrence of circumstances not invariably subsisting. Nurse-bees also produce wax, but in a very inferior quantity to what is elaborated by the real wax-v,urkers. Another characteristic whereby an attentive observer can detcrmine the moment of bees collecting sufficient honey to produce wax, is the strong odour of both these substances from the hive, which is not equally intense at any other time. From such data, it was easy for M. Huber to discover whether the bees 
worked in wax in his own hives, and in those of the other cultivators of the district.

There is still another sort of bees, first observed by Huber in 1809 , which appear to be only casual inmates of the hive, and which are driven forth to starve, or are killed in conflict. They closely resemble the ordinary workers, but are less hairy, and of a much darker colour. These have been called black bees, and are supposed by Huber to be defective bees;* but Kirby and Spence conjecture that they are toil-worn superannuated workers, of no farther use, and are therefore sacrificed, because burdensome to a community which tolerates no unnecessary inmates. The very great numbers of black bees, however, which sometimes appear, does not well accord with such an opinion. The subject remains, therefore, still in uncertainty.

\section{Preparation of Wax.}

In order to build the beautiful combs, which every one must have repeatedly seen and admired, it is indispensable that the architect-bees should be provided with the materials - with the wax, in short, of which they are principally formed. Before we follow them, therefore, to the operation of building, it may be necessary to inquire how the wax itself is procured. Here the discoveries of recent inquirers have been little less singular and unexpected than in other departments of the history of these extraordinary insects. Now that it has been proved that wax is secreted by bees, it is not a little amusing to read the accounts given by our elder naturalists, of its being collected from flowers. Our countryman,

* Huber on Bees, p. 338. 
Thorley,* appears to have been the first who suspected the true origin of wax, and Wildman (1769) seems also to have been aware of it; but R aumur, and particularly Bonnet, thongh both of them in general shrewd and accurate observers, were partially deceived by appearances.

The bees, we are crroneously told, search for wax "upon all sorts of trees and plants, but especially the rocket, the singular poppy, and in general all kinds of flowers. They amass it with their hair, with which their whole body is invested. It is something pleasant to see them roll in the yellow dust which falls from the chives to the bottom of the flowers, and then return covered with the same grains; but their best method of gathering the wax, especially when it is not very plentiful, is to carry away all the little particles of it with their jaws and fore-feet, to press the wax upon them into little pellets, and slide them, one at a time, with their middle feet, into a socket or carity, that opens at their hinder feet, and serves to keep the burden fixed and steady till they return home. They are sometimes exposed to incon. veniences in this work by the motion of the air, and the delicate texture of the flowers which bend under their feet, and hinder them from packing up their booty, on which occasions they fix themselies in some steady place, where they press the wax into a mass, and wind it round their legs, making frequent returns to the flowers; and when they have stocked themselves with a suffieient quantity, they immediatcly repair to their habitation. Two men, in the compass of a whole diy, could not amass so much as two little balls of wax; and yet they are no more than the common burthen of a single bee, and the produce of one journey. 'Those who are employed

* Melisselogia, or Female Monarchy, Sro., Lond. 1744. 
in collecting the wax from flowers are assisted by their companions, who attend them at the door of the hive, ease them of their load at their arrival, brush their feet, and shake out the two balls of wax; upon which the others return to the fields to gather new treasure, whilst those who disburthened them convey their charge to the magazine. But some bees, again, when they have brought their load home, carry it themselves to the lodge, and there deliver it, laying hold of one end by their hinder feet, and with their middle feet sliding it out of the cavity that contained it; but this is evidently a work of supererogation which they are not obliged to perform. 'The packets of wax continue a few moments in the lodge, till a set of officers come, who are charged with a third commission, which is to knead this wax with their feet, and spread it out into different sheets, laid one above another. This is the unwrought wax, which is easily distinguished to be the produce of different flowers, by the variety of colours that appear on each sheet. When they afterwards come to work, they knead it over again, they purify and whiten, and then reduce it to a uniform colour. They use this wax with a wonderful frugality; for it is easy to observe that the whole family is conducted by prudence, and all their actions regulated by good government. Everything is granted to neccssity, but nothing to superfluity; not the least grain of wax is neglected, and if they waste it, they are frequently obliged to provide more; at those very times when they want to get their provision of honey, they take off the wax that closed the cells, and carry it to the magazine." "*

R aumur hesitated in believing that this was a

* Pluche, Spectacle de la Nature, vol. i. 
correct view of the subject, from observing the great difference between wax and pollen; but he was inclined to think the pollen might be swallowed, partially digested, and disgorged in the form of a kind of paste. Schirach aiso mentions, that it was remarked by a certain Lusatian, that wax comes from the rings of the body, because, on withdrawing a bee while it is at work, and extending its body, the wax may be seen there in the form of scales.

The celebrated John Hunter shrewdly remarked that the pellets of pollen seen on the thighs of bees are of different colours on different bees, while the shade of the new-made comb is always uniform; and therefore he concluded that pollen was not the origin of wax. Pollen also, he observed, is collected with greater avidity for old hives, where the comb is complete, than for those where it is only begun, which would hardly be the case were it the material of wax. He found that when the weather was cold and wet in Junc, so that a young swarm was prevented from going abroad, as nuch comb was constructed as had been made in an equal time when the weather was favourable and fine.

The pellets of pollen on the thighs being thence proved not to be wax, he came to the conclusion that it was an external secretion originating between the plates of the belly. When he first observed this, he felt not a little embarassed to explain the phenomenon, and doubted whether new plates were forming, or whether bees cast the old ones as lobsters do their shells. By melting the scales, he ascertained at least that they were wax; and his opinion was confirmed by the fact, that the scales are only to be found during the season when the combs are constructed. But he did not succeed in completing the discovery by observing the bees actually detach the 
scales, though he conjectured they might be taken up by others, if they were once shaken out from between the rings.*

We need not be so much surprised at mistakes committed upon this subject, when we recollect that honey itself was believed by the ancients to be an emanation of the air-a dew that descended upon flowers, as if it had a limited commission to fall only on them. The exposure and correction of error is one of the first steps to genuine knowledge; and when we are aware of the stumbling-blocks which have interrupted the progress of others, we can always travel more securely in the way of truth.

That wax is secreted, is proved both by the wax pouches within the rings of the abdomen, and by actual experiment. $\dagger$ Huber and others fed bees entirely upon honey or sugar, and, notwithstanding, wax was produced and combs formed as if they had been at liberty to select their food. "When bees were confined," says M. Huber, "for the purpose of discovering whether honey was sufficient for the production of wax, they supported their captivity patiently, and showed uncommon perseverance in rebuilding their combs as we removed them. Our experiments required the presence of grubs; honey and water had to be provided; the bees were to be supplied with combs containing brood, and at the same time it was necessary to confine them, that they might not seek pollen abroad. Having a swarm by chance, which had become useless from sterility of the queen, we devoted it for our investigation in one of my leaf hives, which was glazed on both sides. We removed the queen, and substituted combs containing eggs and young grubs, but no cell with farina; even the smallest particle of

* Philosophical Trans. for 1792, p. 143, † See p. 103. VOL. IV. 
the substance which John Hunter conjectured to be the basis of the nutriment of the young, was taken away.

"Nothing remarkable occurred during the first and second day: the bees brooded over the young, and seemed to take interest in them; but at sunset, on the third, a loud noise was heard in the hive. Impatient to discover the reason, we opened a shutter, and saw all in confusion; the brood was abandoned; the workers ran in disorder over the combs; thousands rushed towards the lower part of the hive; and those about the entranee gnawed at its grating. Their design was not equivocal; they wished to quit their prison. Some imperious necessity evidently obliged them to seck elsewhere what they could not find in the hive; and apprehensive that they might perish if I restrained them longer from yielding to their instinet, I set them at liberty. The whole swarm escaped; but the liour being unfavourable for their collections, they flew around the hive, and did not depart far from it. Increasing darkness and the coolness of the air compelled them very soon to return. Probably these cireumstances calmed their agitation; for we observed them peaceably remounting their combs; order seemed re-established, and we took advantage of this moment to elose the hive.

" Next day, the 19th of July, we saw the rudiments of two royal cells, which the bees had formed on one of the brood combs. This crening, at the same hour as on the preeceding, we again lieard a loud buzzing in the closed hive; agitation and disorder rose to the highest degrec, and we were again obliged to let the swarm escape. The bees did not remain long absent fiom their habitation; they quieted and returned as before. We remarked on the 90 th, that the royal cells lsad not beèn continued, as would have been the case in the ordinary state of things. A great tumult 
took place in the evening; the bees appeared to be in a delirium; we set them at liberty, and order was restored on their return. Their captivity having endured five days, we thought it needless to protract it farther; besides, we were desirous of knowing, whether the brood was in a suitable condition, and if it had made the usual progress; and we wished also to try to discover what might be the cause of the periodical agitation of the bees. M. Burnens, (the assistant of Huber) having exposed the two brood combs, the royal cells were immediately recognised; but it was obvious that they had not been enlarged. Why should they! Neither eggs, grubs, nor that kind of paste peculiar to the individuals of their species were there! The other cells were vacant likewise; no brood, not an atom of paste was in them. Thus, the worms had died of hunger. Had we precluded the bees from all means of sustenance by removing the farina? To decide this point, it was necessary to confide other brood to the care of the same insects, now giving them abundance of poller. They had not been enabled to make any collections while we examined their combs. On this occasion they escaped in an apartment where the windows were shut; and after substituting young worms for those they had allowed to pcrish, we returned them to their prison. Next day we remarked that they had resumed courage; they had consolidated the combs, and remained on the brood. They were then provided with fragments of combs, where other workers had stored up farina; and to be able to observe what they did with it, we took this substance from some of their cells, and spread it on the board of the hive. The bees soon discovered both the farina in the combs and what we had exposed to them. They crowded to the cells, and also descending to the bottom of the hives, took the pollen grain by grain in their teeth, 
and conveyed it to their mouths. Those that had eaten it most greedily, mounted the combs before the rest and stopping on the cells of the young worms, inserted their heads, and remained there for a certain time. M. Burnens opened one of the divisions of the hive gently, and powdered the workers, for the purpose of recognising them when they should ascend the combs. He observed them during several hours, and by this means ascertained that they took so great a quantity of pollen only to impart it to their young. Then withdrawing the portions of comb which had been placed by us on the board of the hive, we saw that the pollen had been sensibly diminished in quantity. They were returned to the bees, to augment their provision still farther, for the purpose of extending the experiment. The royal, as well as several common cells were soon closed; and, on opening the hive, all the worms were found to have prospered. Some still had their food before them; the cells of others that had spun were shut with a waxen covering.

"We witnessed these facts repeatedly, and always with equal interest. They so decisively prove the regard of the bees towards the grubs which they are entrusted with rearing, that we shall not seek for any other explanation of their conduct. Another fact, no less extraordinary, and much more difficult to be accounted for, was exhibited by bees constrained to work in wax, several times successively, from the syrup of sugar. Towards the close of the expcriment they ceased to feed the young, though in the beginning these had received the usual attention. They even frequently dragged them from their cells, and carried them out of the hive." "*

Mr Wiston, of Germantown, in the United States,

* Iruber on Bees. 
mentions a fact conclusive on this subject. "I had," says he, "a late swarm last summer, which, in consequence of the drought, filled only one box with honey. As it was late in the season, and the food collected would not enable the bees to subsist for the winter, I shut up the hive, and gave them half a pint of honey every day. They immediately set to work, filled the empty cells, and then constructed new cells enough to fill another box, in which they deposited the remainder of the honey."

A more interesting proof is thus related by the same gentleman. "In the summer of 1824, I traced some wild bees, which had been feeding on the flowers in my meadow, to their home in the woods, and which I found in the body of an oak tree, exactly fifty feet above the ground. Having caused the entrance to the hive to be closed by an expert climber, the limbs were separated in detail, until the trunk alone was left standing. To the upper extremity of this, a tackle-fall was attached, so as to connect it with an adjacent tree, and, a saw being applied below, the naked trunk was cut through. When the immense weight was lowered nearly to the earth, the ropes broke, and the mass fell with a violent crash. The part of the tree which contained the hive, separated by the saw, was conveyed to my garden, and placed in a vertical position. On being released, the bees issued out by thousands, and though alarmed, soon became reconciled to the change of situation. By removing a part of the top of the block, the interior of the hive was exposed to view, and the comb itself, nearly six feet in height, was observed to have fallen down two feet below the roof of the cavity. To repair the damage was the first object of the labourers; in doing which, a large part of their store of honey was expended, because it was at too late a season to obtain materials from abroad. In the folVOL. IV. 
lowing February, these industrious, but unfortunate insects, issuing in a confused manner from the hive, fell dead in thousands, around its entrance, the victims of a poverty created by their efforts to repair the ruins of their habitation.*

In another experiment, IN. Huber confined a swarm so that they had access to nothing beside honey, and five times successively removed the combs with the precaution of preventing the escape of the bees from the apartment. On each occasion they produced new combs, which puts it beyond dispute that honey is sufficient to effect the secretion of wax without the aid of pollen. Instead of supplying the bees with honey, they were subsequently fed, exclusively, on pollen and fruit; but though they were kept in captivity for eight days under a bellglass, with a comb containing nothing but farina, they neither made wax, nor was any secreted under the rings. In another series of experiments, in which bees were fed with different sorts of sugar, it was found that nearly one-sixth of the sugar was converted into wax, dark coloured sugar yielding more than double the quantity of refined sugar.

It may not be out of place to subjoin the few anatomical and physiological facts which have been ascertained by Huber, Madlle, Jurine, and Latreille.

The first stomach of the worker-bee, according to Latreille, $\uparrow$ is appropriated to the reception of honey, but this is never found in the second stomach, which is surrounded with muscular rings, and from one end to the other very much resembles a cask corered with hoops. It is within these rings that the wax is produced, but the secreting vessels for this purpose bave hitherto escaped the researches of the acutest

* American Quarterly Review for June, 1828, p. 382.

+ Latreille, Mem. Acad. des Sciences, 1821. 
naturalists. Huber, however, plausibly enough conjectures that they are contained in the ineternal lining of the wax pockets, which consists of a cellular substance reticulated with hexagons. The wax pockets themselves, which are concealed by the over-lapping of the rings, may be seen by pressing the abdomen of a worker-bee so as to lengthen it, and separate the rings further from each other. When this has been done, there may be seen on each of the four intermcdiate hoops of the belly, and separated by what may be called the keel (carina), two whitish-coloured pouches, of a soft texture, and in the form of a trapezium. Within, the little scales or plates of wax

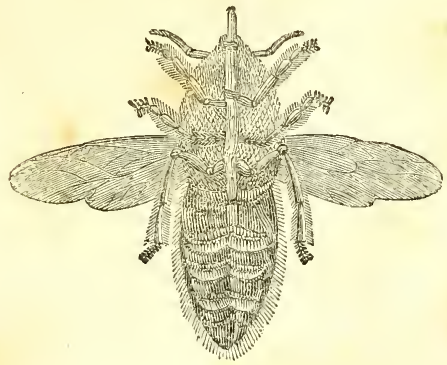

Worker-bae, magnified-showing the position of the scales of $W_{a x}$.

are produced from time to time, and are removed and employed as we shall presently see. We may remark that it is chiefly the wax-workers which produce the wax, for though the nurse-bees are furnished with wax pockets, they secrete it only in very small quantities, while in the queen bee, and the males or drones, no pockets are discoverable. 


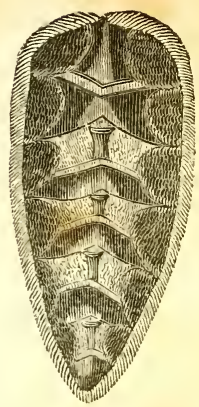

Abdomen of Queen Bcc.

"All the scales," says Huber, "are not ailike in: every bee, for a difference is perceptible in consistence, shape, and thickness; some are so thin and transparent, as to require a magnifier to be recognised, or we have been able to diseover nothing but spicula similar to those of water freezing. Neither the spiculæ nor the scales rest immediately on the membrane of the pocket, a slight liquid medium is interposed, serving to lubricate the joinings of the rings, or to render the extraction of the seales casier, as otherwise they might adhere too firmly to the sides of the poekets." MI. Huber has seen the scales so iarge as to project beyond the rings, being visible without stretching the segments, and of a whitislyellow, from greater thickness lessening their transparency. These shades of diflerence in the scales of various bees, their enlarged dimensions, the fluid interposed beneath them, the correspondence between the scale, and the size and form of the pockets, seem to infer the oozing of this substance through the mem- 
branes whereon it is moulded. He was confirmed in this opinion by the escape of a transparent fluid on piercing the membrane, whose internal surface seemed to be applied to the soft parts of the belly. This he found coagulated in cooling, when it resembled wax, and again liquified on exposure to heat. The scales themselves, also, melted and coagulated like wax.**

By chemical analysis, however, it appears that the wax of the rings is a more simple substance than that which composes the cells; for the latter is soluble in ether, and in spirit of turpentine, while the former is insoluble in ether, and but partially soluble in spirit of turpentine. It should seem to follow, that if the substance found lying under the rings be really the elements of wax, it undergoes some subsequent preparation after it is detached; and that the bees, in short, are capable of impregnating it with matter, imparting to it whiteness and ductility, whereas in its unprepared state it is only fusible.

\section{Propolis.}

Wax is not the only material employed by bees in their architecture. Besides this, they make use of a brown, odoriferous, resinous substance, called propolis, $\uparrow$ more tenacious and extensible than wax, and well adapted for cementing and varnishing. It was strongly suspected by Réaumur, that the bees collected the propolis from those trees which are known to produce a similar gummy resin, such as the poplar, the birch, and the willow; but he was thrown into doubt by not being able to detect the bees in the act of procuring it, and by observing them to collect

* Huber on Bees, p. 325.

+ From two Greel words $\pi \rho^{\circ}$ a $0 \lambda / s$ meaning before the city, as the substance is principally applied to the projecting parts of the hive. 
it where none of those trees, nor any other of the same description, grew. His bees also refused to make use of bitumen, and other resinous substances, with which he supplied them, though Mr Knight, as we shall afierwards see, was more successful.*

Long before the time of Ri aumur, however, Mouffet, in his Insectarum Theatrum, quotes Cordus for the opinion, that propolis is collected from the buds of trees, such as the poplar and birch; and Reim says it is collected from the pine and fir. $\dagger$ Huber at length set the question at rest; and his experiments and observations are so interesting, that we shall give them in his own words:-

"For many years," says he, "I had fruitlessly endeavoured to find them on trees producing an analogous substance, though multitudes had been seen returning laden with it.

"In July, some branches of the wild poplar, which had been cut since spring, with very large buds, full of a reddish, viscous, odoriferous matter, were brought to me, and I planted them in vessels before hives, in the way of the bees going out to forage, so that they could not be insensible of their presence. Within a quarter of an hour, they were risited by a bee, which separating the sheath of a bud with its teeth, drew out threads of the viscous substance, and lodged a pellet of it in one of the baskets of its limbs: fiom another bud it collected another pellet for the olposite limb, and departed to the hive. A second bee took the place of the former in a few minutes, following the same procedure. Young shoots of poplar, recently cut, did not seem to attract these insects, as their viscous matter had less consistence than the former.t

* Phil. Trans. for 1807 , p. 242.

† Schirach, Hist. des Abeilles, p. 211.

‡ Kirby and Spence observed bees very buay in collecting 
" Different expcriments proved the identity of this substance with propolis; and now, having only to discover how the bees applied it to use, we peopled a hive, so prepared as to fulfil our views. The bees, building upwards, soon reached the glass above; but, unable to quit their habitation, on account of rain, they were three weeks without bringing home propolis. Their combs remained perfectly white until the beginning of July, when the state of the atmosphere became more favourable for our observations. Serene warm weather engaged them to forage, and they returned from the fields laden with a resinous gum, resembling a transparent jelly, and having the colour and lustre of the garnet. It was easily distinguished from the farinaceous pellets then collected by other bees. The workers bearing the propolis ran over the clusters suspended from the roof of the hive, and rested on the rods supporting the combs, or sometimes stopped on the sides of their dwelling, in expectation of their companions coming to discncumber them of their burden. We actually saw two or three arrive, and carry the propolis from off the limbs of each with their teeth. The upper part of the hive exhibited the most animated spectacle: thither a multitude of bees resorted from all quarters, to engage in the predominant occupation of the collection, distribution, and application of the propolis. Some conveyed that of which they had unloaded the purveyors in their teeth, and deposited it in heaps; others hastened, before its hardening, to spread it out like a varnish, or formed it into strings, proportioned to the interstices of the sides of the hive to be filled up. Nothing could be more diversified than the operations carried on.

"The bees, apparently charged with applying the

propolis from the tacamahaca tree (Populus balsamifera.) Jntrod., ii. 186. 
propolis within the cells, were easily distinguished from the multitude of workers, by the direction of their heads towards the horizontal pane forming the roof of the hive, and on reaching it, they deposited their burden nearly in the middle of intervals separating the combs: then they conveyed the propolis to the real place of its destination. They suspended themselves by the claws of the hind legs to points of support, afforded by the viscosity of the propolis on the glass; and, as it were, swinging themselves backwards and forwards, brought the heap of this substance nearer to the cells at each impulse. Here the bees employed their fore feet, which remained free, to sweep what the teeth had detached, and to unite the fragments scattered over the glass, which recovered all its transparency when the whole propolis was brought to the vicinity of the cells.

"6 After some of the bees had smoothed down and cleaned out the glazed cells, feeling the way with their antennæ, one desisted, and having approached a heap of propolis, drew out a thread with its teeth. This being broken off, it was taken in the claws of the fore feet, and the bee, re-cntering the cell, immediately placed it in the angle of two portions that had been sinoothed, in which operation the fore feet and teeth were used alternately; but probably proving too clumsy, the thread was reduced and polished; and we admired the accuracy with which it was adjusted when the work was completed. The insect did not stop here: returning to the cell, it prepared other parts of it to receive a second thread, for which we did not doubt that the heap would be resorted to. Contrary to our expectation, however, it availed itself of the portion of the thread cut off on the former occasion, arranged it in the appointed place, and gave it all the solidity and finish of which it was susceptible. Other bees concluded the work which the first had begum; and the sides of the cells weie 
speedily secured with threads of propolis, while some were also put on the orifices; but we could not seize the moment when they were varnished, though it may be easily conceived how it is done."

This is not the only use to which bees apply the propolis. They are extremely solicitous to remove such insects or foreign bodies as happen to get admission into the hive. When so light as not to exceed their powers, they first kill the insect with their stings, and then drag it out with their teeth. But it sometimes happens, as was first observed by Maraldi, and since by Réaumur and others, that an ill-fated snail creeps into the hive: this is no sooner perceived than it is attacked on all sides, and stung to death. But how are the bees to carry out so heavy a burthen? Such a labour would be in vain. To prevent the noxious smell which would arise from its putrefaction, they immediately embalm it, by covering every part of its body with propolis, through which no effluvia can escape. When a snail with a shell gets entrance, to dispose of it gives much less trouble and expense to the bees. As soon as it receives the first wound from a sting, it naturally retires within its shell. In this case, the bees, instead of pasting it all over with propolis, content themselves with gluing all round the margin of the shell, which is sufficient to render the animal for ever immovably fixed.

Mr Knight, the learned and ingenious President of the Horticultural Society, discovered by accident an artificial substance, more attractive than any of the resins experimentally tried by Réaumur. Having caused the decorticated part of a tree to be covered with a cement, composed of bees'-wax and turpentine, he observed that this was frequented by hive-bees, who, finding it to be a very good propolis ready made,

* Huber on Bees, p. 408.

VOL. IV. 
detached it from the tree by their mandibles, and then, as usual, passed it from the first leg to the second, and so on. When one bee had thus collected its load, another often came behind and despoiled it of all it had collected; a second and a third load were frequently lost in the same manner; and yet the patient insect pursued its operations without manifesting any signs of anger.* Probably the latter circumstance, at which $\mathrm{Mr}$ Knight seems to have been surprised, was nothing more than an instance of the division of labour so strikingly exemplified in every part of the economy of bees.

It may not be out of place liere to describe the apparatus with which the worker-bees are provided for the purpose of carrying the propolis as well as the pollen of flowers to the hive, and which has just been alluded to in the observations of Mr Knight. The shin or middle portion of the hind pair of legs is actually formed into a triangular basket, admirably adapted to this design. The bottom of this basket
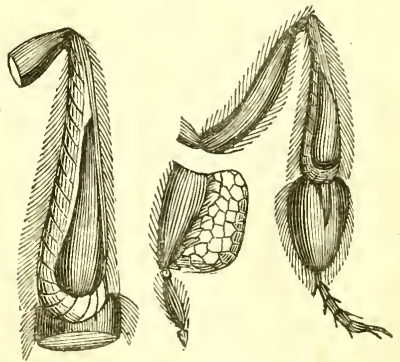

Strusture of the legs of the Bec for carying propoits and jollen, magnified.

* Philosophical Trans, for : 907, p. 242. 
is composed of a smooth, shining, horn-like substance, hollowed cut in the substance of the limb, and surrounded with a margin of strong and thicklyset bristles. Whatever materials, therefore, may be placed by the bee in the interior of this basket, are secured from falling out by the bristles around it, whose elasticity will even allow the load to be heaped beyond their points without letting it fall.

In the case of propolis, when the bee is loading her singular basket, she first kneads the piece she has detached with her mandibles, till it becomes somewhat dry and less adhesive, as otherwise it would stick to her limbs. This preliminary process sometimes occupies nearly half an hour. She then passes it backwards by means of her feet to the cavity of her basket, giving it two or three pats to make it adhere; and when she adds a second portion to the first, she often finds it necessary to pat it still harder. When she has procured as much as the basket will conveniently hold, she flies off with it to the hive.

\section{The Bullding of the Cells.}

The notion commonly entertained respecting glass hives is altogether erroneous. Those who are unacquainted with bees imagine, that, by means of a glass hive, all their proceedings may be easily watched and recorded; but it is to be remembered that bees are exceedingly averse to the intrusion of light, and their first operation in such cases is to close up every chink by which light can enter to disturb them, either by clustering together, or by a plaster composed of propolis. It consequently requires considerable management and ingenuity, even with the aid of a glass hive, to sce them actually at work. M. Huber employed a hive with leaves, which opened in the manner of a book; and for some purposes he 
used a glass box, inserted in the body of the hive, but easily brought into view by means of screws.

But no invention hitherto contrived is sufficient to obviate c very difficulty. The bees are so eager to afford $m$ ' tual assistance, and for this purpose so many of them crowd together in rapid succession, that the operations of individuals can seldom be traced. Thongh this crowding, however, appears to an observer to be not a little confused, it is all regulated with admirable order, as has been ascertained by Réaumur and other distinguished naturalists.

When bees begin to build the hive, they divide themselves into bands, one of which produces materials for the structure; another works upon these, and forms them into a rough sketch of the dimensions and partitions of the cells. All this is completed by the second band, who examine and adjust the angles, remove the superfinous wax, and give the work its necessary perfection; and a third band brings provisions to the labourers, who cannot leave their work. But no distribution of food is made to those whose charge, in collecting propolis and pollen, calls them to the field, because it is supposed they will hardly forget themselves; neither is any allowance made to those who begin the architecture of the cells. Their province is very troublesome, because they are obliged to level and extend, as well as cut and adjust the wax to the dimensions required; but then they soon obtain a dismission from this labour, and retire to the fields to regale themselves with food, and wear off their fatigue with a more agreeable employment. Those tho sueced them, draw their mouth, their feet, and the extremity of their body, several times over all the work, and never desist till the whole is polished and completed; and as they frequently need refreshments, and yet are not permitted to retire, 
there are waiters always attending, who serve them with provisions when they require them. The labourer who has an appetite, bends down his trunk before the caterer, to intimate that he has an inclination to eat, upon which the other opens his bag of honey, and pours out a few drops; these may be distinctly seen rolling through the whole of his trunk, which insensibly swells in every part the liquor flows through. When this little repast is over, the labourer returns to his work, and his body and feet repeat the same motions as before.*

Before they can commence building, however, when a colony or swarm migrates from the original hive to a new situation, it is necessary first to collect propolis, with which every chink and cranny in the place where they mean to build may be carefully stopped up; and secondly that a quantity of wax be secreted by the wax-workers to form the requisite cells. The secretion of wax, it would appear, goes on best when the bees are in a state of repose; and the wax-workers, accordingly, suspend themselves in the interior in an extended cluster, like a curtain which is composed of a series of intertwined festoons or garlands, crossing each other in all directions, the uppermost bee maintaining its position by laying hold of the roof with its fore-legs, and the succeeding one by laying hold of the hind legs of the first.

"A person," says Réaumur, "must have been born devoid of curiosity not to take interest in the investigation of such wonderful proceedings." Yet Réaumur himself seems not to have understood that the bees suspended themselves in this manner to secrete wax, but merely, as he imagined, to recruit themselves by rest for renewing their labours. The bees composing the festooned curtain are individually motionless; but this curtain is, notwithsianding,

* Spectacle de la Nature, tom. i.

VOL. IV.

$10^{*}$ 
kept moving by the proceedings in the interior; for the nurse-bees never form any portion of it, and continue their activity-a distinction with which Réaumur was unacquainted.

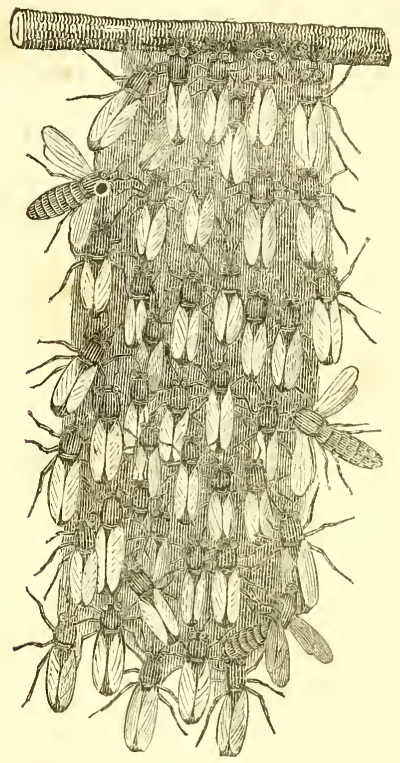

Curtain of $W$ ax-worhers scercting $W a x$.

Although there are many thousand labourers in a hive, they do not commence foundations for combs 
in several places at once, but wait till an individual bee has selected a site, and laid the foundation of a comb, which serves as a directing mark for all that are to follow. Were we not expressly told by so accurate an observer as Huber, we might hesitate to believe that bees, though united in what appears to be a harmonious monarchy, are strangers to subordination, and subject to no discipline. Hence it is, that though many bees work on the same comb, they do not appear to be guided by any simultaneous impulse. The stimulus which moves them is successive. An individual bee commences each operation, and several others successively apply themselves to accomplish the same purpose. Each bee appears, therefore, to act individually, either as directed by the bees preceeding it, or by the state of advancement in which it finds the work it has to proceed with. If there be anything like unanimous consent, it is the inaction of several thousand workers while a single individual proceeds to determine and lay down the foundation of the first comb. Rêaumur regrets, that, though he could by snatches detect a bee at work in founding cells or perfecting their structure, his observations were generally interrupted by the crowding of other bees between him and the little builder. He was therefore compelled rather to infer the different steps of their procedure from an examination of the cells. when completed, than from actual observation. The ingenuity of Huber, even under all the disadvantages of blindness, succeeded in tracing the minutest operations of the workers from the first waxen plate of the foundation. We think the narrative of the discoverer's experiments, as given by himself, will be more interesting than any abstract of it which we could furnish.

" Having taken a large bell-shaped glass receiver, we glued thin wooden slips to the arch at certain in- 
tervals, because the glass itself was too smooth to admit of the bees supporting themselves on it. A swarm, consisting of some thousand workers, several hundred males, and a fertile queen, was introduced, and they soon ascended to the top. 'Those first gaining the slips, fixed themselves there by the forefeet; others scrambling up the sides, joined them, by holding their legs with their own, and they thus formed a kind of chain, fastened by the two ends to the upper parts of the receiver, and served as ladders or a bridge to the workers enlarging their number. The latter were united in a cluster, hanging like an inverted pyramid from the top to the bottom of the hive.

" The country then affording little honey, we provided the bees with syrup of sugar, in order to hasten their labour. They crowded to the cdge of a ressel containing it; and, having satisficd themselves, returned to the group. We were now struck with the absolute repose of this hive, contrasted with the usual agitation of bees. Meanwhile, the nurse-bees alone went to forage in the country: they returned with pollen, kept guard at the entrance of the hive, cleansed it, and stopped up its edges with propolis. The wax-workers remained motionless above fifteen hours: the curtain of bces, consisting always of the same individuals, assured us that none eplaced them. Some hours later, we remarked that almost all these individuals had wax scales under the rings; and next day this phenomenon was still more general. The bees forming the external layer of the cluster, having now somewhat altered their position, enabled us to see their bellies distinctly. By the projection of the wax scales, the rings seemed cdged with white. The curtain of bees became rent in several places, and some commotion began to be observed in the hive.

"Convinced that the combs would originate in 
the centre of the swarm, our whole attention was then directed towards the roof of the glass. A worker at this time detached itself from one of the central festoons of the cluster, separated itself from the crowd, and, with its head, drove away the bees at the beginning of the row in the middle of the arch, turning round to form a space an inch or more in diameter, in which it might move freely. It then fixed itself in the centre of the space thus cleared.

" The worker now employing the pincers at the joint of one of the third pair of its limbs, seized a scale of wax projecting from a ring, and brought it forward to its mouth with the claws of its fore-legs,

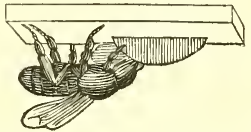

Wax-worker laying the foundation of the first Cell.

where it appeared in a vertical position. We remarked, that, with its claws, it turned the wax in every necessary direction; that the edge of the scale was immediately broken down, and the fragments having been accumulated in the hollow of the mandibles, issued forth like a very narrow ribbon, impregnated with a frothy liquid by the tongue. The tongue itself assumed the most varied shapes, and executed the most complicated operations,-being sometimes flattened like a trowel, and at other times pointed like a pencil; and, after imbuing the whole substance of the ribbon, pushed it forward again into the mandibles, whence it was drawn out a second time, but in an opposite direction.

"At length the bee applied these particles of wax to the vault of the hive, where the saliva impregnating them promoted their adhesion, and also com- 
municated a whiteness and opacity, which where wanting when the scales were detached from the rings. Doubtless, this process was to give the wax that ductility and tenacity belonging to its perfect state. The bee then separated those portions not yet applied to use with its mandibles, and with the same organs afterwards arranged them at pleasure. The founder bee, a name appropriate to this worker, repeated the same operation, until all the fragments, worked up and impregnated with the fluid, were attached to the vault, when it repeated the preceding operations on the part of the scale yet kept apart, and again united to the rest what was obtained from it. A second and third scale were similarly treated by the same bee; yet the work was only sketched; for the worker did nothing but accumulate the particles of wax together. Meanwhile, the founder, quitting its position, disappeared amidst its companions. Another, with wax under the rings, succeeded it, which, suspending itself to the same spot, withdrew a scale by the pincers of the hind legs, and passing it through its mandibles, prosecuted the work; and taking care to make its deposit in a line with the former, it united their extremities. A third worker, detaching itself from the interior of the cluster, now came and reduced some of the scales to paste, and put them near the materials accumulated by its companions, but not in a straight line. Another bee, apparently sensible of the defect, removed the misplaced wax before our eyes, and carrying it to the former heap, deposited it there, exactly in the order and direction pointed out.

"From all these operations was produced a block of a rugged surface, hanging down from the arch, without any perceptible angle, or any traces of cells. It was a simple wall, or ridge, running in a straight line, and without the least inflection, two-thirds of 
an inch in length, about two-thirds of a cell, or two lines, high, and declining towards the extremities. We have seen other foundation walls from an inch to an inch and a half long, the form being always the same; but none ever of greater height.

" The vacuity in the centre of the cluster had permitted us to discover the first mancuvres of the bees, and the art with which they laid the foundations of their edifices. However, it was filled up too soon for our satisfaction; for workers collecting on both faces of the wall obstructed our view of their further operations." "**

* Huber on Bees, p. 358.

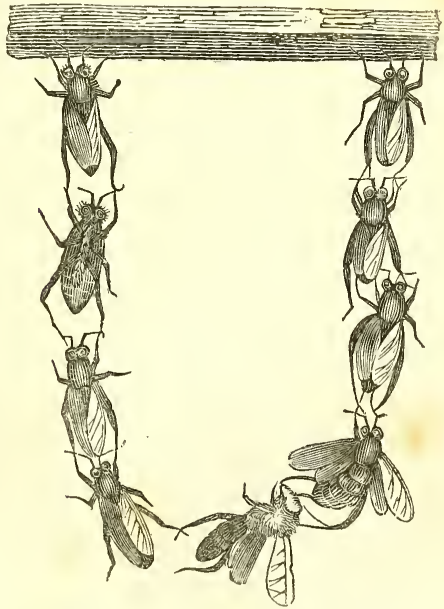

Curlatin of Wax-workers.-(B)eE D. 114.) 


\section{Chapter Vi.}

Architecture of the Hive-Bee continued.-Form of the Cells.

The obstruction of which M. Huber complains only operated as a stimulus to his ingenuity in contriving how he might continue his interesting observations. From the time of Pappus to the present day, mathematicians have applied the principles of geometry to explain the construction of the cells of a bee-hive; but though their extraordinary regularity, and wonderfully selected form, had so often been investigated by men of the greatest talent, and skilled in all the refinements of science, the process by which they are constructed, involving also the causes of their regularity of form, had not been traced, till MI. Huber devoted himself to the inquiry.

As the wax-workers secrete only a limited quantity of wax, it is indispensably requisite that as little as possible of it should be consumed, and that none of it should be wasted. Bees, therefore, as M. Ri aumur well remarks,* have to solve this difficult geometrical problem:-A quantity of wax being given, to form of it similar and equal cells of a determinate capacity, but of the largest size in proportion to the quantity of matter employed, and disposed in such a manner as to occupy the least possible space in the hive. This problem is solved by bees in all its conditions. The cylindrical form would seem to be best adapted to the shape of the insect; but had the cells been cylindrical, they could not have been applied to

* Réaumur, vol. v. p,380. 
each other without leaving a vacant and superfluous space between every three contiguous cells. Had the cells, on the other hand, been square or triangular, they might have been constructed without unnecessary vacancies; but these forms would have both required more material and been very unsuitable to the shape of a bee's body. The six-sided form of the cells obviates every objection; and while it fulfils the conditions of the problem, it is equally adapted with a cylinder to the shape of the bee.

M. Reaumur further remarks, that the base of each cell, instead of forming a plane, is usually composed of three pieces in the shape of the diamonds on playing cards, and placed in such a manner as to form a hollow pyramid. This structure, it may be observed, imparts a greater degree of strength, and, still keeping the solution of the problem in view, gives a great capacity with the smallest expenditure of material. This has actually, indeed, been ascertained by mathematical measurement and calculation. Maraldi, the inventor of glass hives, determined, by minutely measuring these angles, that the greater were $109^{\circ} 2^{\prime}$, and the smaller, ${ }^{3} 0^{\circ}{ }^{\circ} 2^{\prime}$; and $\mathbf{M}$. Réaumur, being desirous to know why these particular angles are selected, requested M. Kœenig, a skilful mathematician, (without informing him of his design, or telling him of Maraldi's researches,) to letermine, by calculation, what ought to be the angle of a six-sided cell, with a concave pyramidal base, formed of three similar and equal rhomboid plates, so that the least possible matter should enter into its construction. By employing what geometricians denominate the infinitesimal calculus, M. Konig found that the angles should be $109^{\circ} 26^{\prime}$ for the greater, and $70^{\circ} 34^{\prime}$ for the smaller, or about two sixtieths of a degree, more or less, than the actual angles made choice of by bees. The equality of inclination in the

VOL. IV, 
angles has also been said to facilitate the construction of the cells.

M. Huber adds to these remarks, that the cells of the first row, by which the whole comb is attached to the roof of a hive, are not like the rest; for instead of six sides they have only five, of which the roof forms one. The base, also, is in these different, consisting of three pieces on the face of the comb, and on the other side of two: one of these only is diamond shaped, while the other two are of an irregular four-sided figure. This arrangement, by bringing the greatest number of points in contact with the interior surface, ensures the stability of the comb.

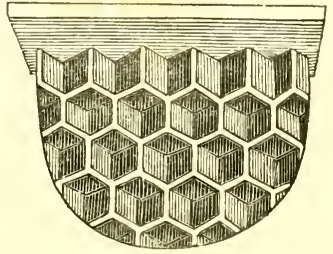

Arrangement of cells.

It may, however, be said not to be quite certain, that Reaumur and others have not ascribed to bees the merit of ingenious mathematical contrivance and selection, when the construction of the cells may more probably originate in the form of their mandibles and other instruments cmployed in their operations. In the case of other insects, we have, both in the preceding and subsequent pages of this volume, repeatedly noticed, that they use their bodies, or parts thercof, as the standards of measurement and modelling; and it is not impossible that bees may proceed on a similar principle. M. Huber replies to this objection, 
that bees are not provided with instruments corresponding to the angles of their cells; for there is no more resemblance between these and the form of their mandibles, than between the chisel of the sculptor and the work which he produces. The head, he thinks, does not furnish any better explanation. He admits that the antennæ are very flexible, so as to enable the insects to follow the outline of every object; but concludes that neither their structure, nor that of the limbs and mandibles, are adequate to explain the form of the cells, though all these are employed in the operations of building,the effect, according to him, depending entirely on the object which the insect proposes.

We shall now follow M. Huber in the experiments which he contrived, in order to observe the operations of the bees subsequent to their laying a foundation for the first cell; and we shall again quote from his own narrative:-

"It appeared to me," he says, "that the only method of isolating the architects, and bringing them individually into view, would be to induce them to change the direction of their operations, and work upwards.

"I had a box made twelve inches square and nine deep, with a moveable glass lid. Combs full of brood, honey, and pollen, were next selected from one of my leaf hives, as containing what might interest the bees, and being cut into pieces a foot long, and four inches deep, they were arranged vertically at the bottom of the box, at the same intervals as the insects themselves usually leave between them. A small slip of wooden lath covered the upper edge of each. It was not probable that the bees would attempt to found new combs on the glass roof of the box, because its smoothness precluded the swarm from adhering to it; therefore, if disposed to build, 
they could do so over the slips resting on the combs, which left a vacuity five inches high above them. As we had foreseen, the swarm with which this box was peopled established itself among the combs below. We then observed the nurse-bees displaying their natural activity. They dispersed themselves throughout the hive, to feed the young grubs, to clear out their lodgment, and adapt it for their convenience. Certainly, the combs, which were roughly cut to fit the bottom of the box, and in some parts damaged, appeared to them shapeless and misplaced; for they speedily commenced their reparation. They beat down the old wax, kneaded it between their teeth, and thus formed binding materials to consolidate them. We were astonished beyond expression by such a multitude of workers employed at once in labours to which it did not appear they should have been called, at their coincidence, their zeal, and their prudence.

"But it was still more wonderful, that about half" the numerous population took no part in the proceedings, remaining motionless, while the others fulfilled the functions required. The wax-workers, in a state of absolute repose, recalled our former observations. Gorged with the honey we had put within their reach, and continuing in this condition during twenty-four hours, wax was formed under their rings, and was now ready to be put in operation. To our great satisfaction we soon saw a little foundation wall rising on one of the slips that we had prepared to reccive the superstructure. No obstacle was offered to the progress of our olsservations; and for the second time, we beheld both the undertaking of the founder bee, and the suceessive labours of several wax-workers, in forming the foundation wall. Would that my readers could share the interest which the view of these architects inspired! 
" This foundation, originally very small, was enlarged as the work required; while they excavated on one side a hollow, of about the width of a common cell, and on the opposite surface two others somewhat more elongated. The middle of the single cell corresponded exactly to the partition separating the latter; the arches of these excavations, projecting by the accumulation of wax, were converted into ridges in a straight line; whence the cells of the first row were composed of five sides, considering the slip as one side, and those of the second row, of six sides.
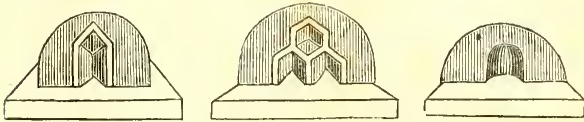

Foundation-wall enlarged, and the cells cormenced.

" The interior conformation of the cavities, apparently, was derived from the position of their respective outlines. It seened that the bees, endowed with an admirable delicacy of feeling, directed their teeth principally to the place where the wax was thickest; that is, the parts where other workers on the opposite side had accumulated it; and this explains why the bottom of the cell is excavated in an angular direction behind the projection on the sides of which the sides of the corresponding cells are to rise. The largest of the excavations, which was opposite to three others, was divided into three parts, while the excavations of the first row on the other face, applied against this one, were composed of only two.

"6 In consequence of the manner in which the excavations were opposed to each other, those of the second row, and all subsequent, partially applied to three cavities, were composed of three equal diamondrol. 15. 
shaped lozenges. I may here remark, that each part of the labour of bees appears the natural result of what has preceded it; therefore, chance has no share in these admirable combinations.

"A foundation wall rose above the slip like a minute vertical partition, five or six lines long, two lines high, but only half a line in thickness; the edge circular, and the surface rough. Quitting the cluster among the combs, a nurse-bee mounted the slip, turned around the block, and visiting both sides, began to work actively in the middle. It removed as much wax with its teeth as might equal the diameter of a common cell; and after kneading and moistening the particles, deposited them on the edge of the excavation. This insect, having laboured some seconds, retired, and was soon replaced by another; a third continued the work, raising the margin of the edges, now projecting from the cavity, and with assistance of its teeth and feet fixing the particles, so as to give these edges a straighter form. More than twenty bees successively participated in the same work; and when the cavity was little above a line and a half in height, though equally a cell in width, a bee left the swarm, and after encircling the block, commenced its operations on the opposite face, where yet untouched. But its teeth acting only on one half of this side, the hollow which it formed was opposite to only one of the slight prominences bordering the first cavity. Nearly at the same time another worker began on the right of the face that had been untouched, wherein both were occupied in forming cavities, which may be designed the second and third; and they also were replaced by substitutes. These two latter cavitics were separated only by the common margin, framed of particles of wax withdrawn from them; which margin corresponded with the centre of the cavity on the opposite surface. 
The foundation wall itself was still of insufficient dimensions to admit the full diameter of a cell; but while the excavations were deepened, wax-workers extracting their scales of wax applied them in enlarging its circumference; so that it rose nearly two lines further around the circular arch. The nurse-bees, which appeared more especially charged with sculpturing the cells, being then enabled to continue their outlines, prolonged the cavities, and heightened their margins on the new addition of wax.

"The arch, formed by the cdge of each of these cavities, was next divided as by two equal chords, in the line of which the bees formed stages or projecting borders, or margins meeting at an obtuse angle; the cavities now had four margins, two lateral and perpendicular to the supporting slip, and two oblique, which were shorter.

"Meantime, it became more difficult to follow the operations of the bees, from their frequently interposing their heads between the eye of the observer and the bottom of the cell; but the partition, whereon their teeth laboured, had become so transparent, as to expose what passed on the other side.

"The cavities of which we speak, formed the bottom of the first three cells; and while the bees engaged were advancing them to perfection, other workers commenced sketching a second row of cells above the first, and partly behind those in frontfor in general, their labour proceeds by combination. We cannot say, 'When bees have finished this cell, they will begin new ones;' but, 'while particular workers advance a certain portion, we are certain that others will carry on the adjacent cells.' Farther, the work begun on one face of the comb is already the commencement of that which is to follow on the reverse. All this depends on a reciprocal relation, or a mutual connexion of the parts, rendering the 
whole subservient to each other. It is undoubted, therefore, that slight irregularities on the front will affect the form of the cells on the back of the comb." **

When they have in this manner worked the bottoms of the first row of cells into the required forms, some of the nurse-bees finish them by imparting a sort of polish, while others proceed to cut out the rudiments of a second row from the fresh wall of wax which has been built in the meanwhile by the wax-workers, and also on the opposite side of this wall; for a comb of cells is always double, being arranged in two layers, placed end to end. The cells of this second row are engrafted on the borders of cavities hollowed out in the wall, being founded by the nurse-bees, bringing the contour of all the bottoms, which is at first unequal, to the same level; and this level is kept uniform in the margins of the cells till they are completed. At first sight, nothing appears more simple, than adding wax to the margins; but from the inequalities occasioned by the shape of the bottom, the bees must accumulate wax on the depressions, in order to bring them to a level. It follows accordingly that the surface of a new comb is not quite flat, there being a progressive slope produced as the work proceeds, and the comb being therefore in the form of a lens, the thickness decreasing towards the edge, and the last formed cells being shallower or shorter than those preceding them. So long as there is room for the enlargement of the comb, this thinning of its edge may be remarked; but as soon as the space within the hive prevents its enlargement, the cells are made equal, and two flat and level surfaces are produced.

M. Huber observed, that while sketching the bottom of a cell, before there was any upright margin on the reverse, their pressure on the still soft

* Huber on Bees, p. 368. 
and flexible wax gave rise to a projection, which sometimes caused a breach of the partition. This, however, was soon repaired, but a slight prominence always remained on the opposite surface, to the right and left of which they placed themselves, to begin a new excavation; and they heaped up part of the materials between the two flutings formed by their labour. The ridge thus formed becomes a guide to the direction which the bees are to follow for the vertical furrow of the front cell.

We have already seen that the first cell determines the place of all that succeed it, and two of these are never in ordinary circumstances begun in different parts of the hive at the same time, as is alleged by some earlier writers. When some rows of cells, however, have been completed in the first comb, two other foundation walls are begun, one on each side of it, at the exact distance of one-third of an inch, which is sufficient to allow two bees employed on the opposite cells to pass each other without jostling. These new walls are also parallel to the former; and two more are afterwards begun exterior to the second, and at the same parallel distance. The combs are uniformly enlarged, and lengthened in a progression proportioned to the priority of their origin; the middle comb being always advanced beyond the two adjoining ones by several rows of cells, and these again beyond the ones exterior to them. Did the bees lay the foundations of all their combs at the same time, they would not find it easy to preserve parallelism and an equality in their distances. It may be remarked further, that beside the vacancies of half an inch between the cells, which form what we may call the highways of the community, the combs are pierced in several places with holes which serve as postern-gates for easy communication from one to another, to prevent loss of time in going round. The 
equal distance between the combs is of more importance to the welfare of the hive than might at first appear; for were they too distant, the bees would be so scattered and dispersed, that they could not reciprocally communicate the heat indispensable for hatching the eggs and rearing the young. If the combs, on the other hand, were closer, the bees could not traverse the intervals with the freedom necessary to facilitate the work of the hive. On the approach of winter, they sometimes elongate the cells which contain honey, and thus contract the intervals between the combs. But this expedient is in preparation for a season when it is important to have copious magazines, and when their activity being relaxed, it is unnecessary for their communications to be so spacious and free. On the return of spring, the bees hasten to contract the elongated cells, that they may become fit for receiving the eggs which the queen is about to deposit, and in this manner they re-establish the regular distance.*

We are indebted to the late Dr Barclay of Edinburgh, well known as an excellent anatomist, for the discovery that each cell in a honeycomb is not simply composed of one wall, but consists of two. We shall give the account of his discovery in his own words:

"Having inquired of several naturalists whether or not they knew any author who had mentioned that the partitions between the cells of the honeycomb were double, and whether or not they had ever remarked such a structure themselves, and they having answered in the negative; I now take the liberty of presenting to the Society, pieces of honeycomb, in which the young bees had been reared, upon breaking which, it will be clearly seen that the partitions between different cells, at the sides and the

* Huber on Bees, p. 220. 
base, are all double; or, in other words, that each cell is a distinct, separate, and in some measure an independent structure, agglutinated only to the neighbouring cells; and that when the agglutinating substance is destroyed; each cell may be entirely separated from the rest.

"I have also some specimens of the cells formed by wasps, which shew that the partitions between them are also double, and that the agglutinating substance between them is more easily destroyed than that between the cells of the bee."

\section{IRREgULARITIES IN THEIR WorkMaNSHIP.}

Though bees, however, work with great uniformity when circumstances favour their operations, they may be compelled to vary their proceedings. MI. Huber made several ingenious experiments of this kind. The following, mentioned by Dr Bevan, was accidental, and occured to his friend Mr Walond. "Inspecting his bee-boxes at the end of October, 1817, he perceived that a centre comb, burdened with honey, had separated from its attachments, and was leaning against another comb, so as to prevent the passage of the bees between them. This accident excited great activity in the colony; but its nature could not be ascertained at the time. At the end of a week, the weather being cold, and the bees clustered together, Mr Walond observed, through the window of the box, that they had constructed two horizontal pillars betwixt the combs alluded to; and had removed so much of the honey and wax from the top of each, as to allow the passage of a bee: in about ten days more, there was an uninterrupted thoroughfare; the detached comb at its upper part had been secured by a strong barrier, and

* Memoirs of the Wernerian Nat. Hist. Soc. vol. ii. p. 260. 
fastened to the window with the spare wax. This: being accomplished, the bees removed the horizontal pillars first constructed as being of no further use."

A similar anecdote is told by M. Huber. "6 During the winter," says he, "a comb in one of my bell-glass hives, having been originally insecure, fell down, but preserved its position parallel to the rest. The bees were unable to fill up the vacuity left above it, because they do not build combs of old wax, and none new could be then obtained. At a more favourable season they would have ingrafted a new comb on the old one; but now their provision of honey could not be spared for the elaboration of this substance, which induced them to ensure the stability of the comb by another process.

"6rowds of bees taking wax from the lower part of other combs, and even gnawing it from the surface of the orifices of the deepest cells, they constructed so many irregular pillars, joists, or buttresses, between the sides of the fallen comb, and others on the glass of the hive. All these were artificially adapted to localities. Neither did they confine themselves to repairing the accidents which their works had sustained. They seemed to profit by the warning, to guard against a similar casualty.

" The remaining combs were not displaced; therefore, while solidly adhering by the base, we were greatly surprised to see the bees strengthen their principal fixtures with old wax. They rendered them much thicker than before, and fabricated a number of new connexions, to unite them more firmly to each other, and to the sides of their dwelling. All this passed in the middle of January, a time that these insects commonly keep in the upper part of their hive, and when work is no longer seasonable." $†$

M. Huber the younger shrewdly renrarks, that

* Bevan on Bees, p. 326.

+ Iluber on Bees, p. 116 
the tendency to symmetry observable in the architecture of bees, does not hold so much in small details as in the whole work, because they are sometimes obliged to adapt themselves to particular localities. One irregularity leads on to another, and it commonly arises from mere accident, or from design on the part of the proprietor of the bees. By allowing, for instance, too little interval between the spars for rcceiving the foundation of the combs, the structure has been continued in a particular direction. The bees did not at first appear to be sensible of the defect, though they afterwards began to suspect their error, and were then observed to change their line of work till they gained the customary distance. The cells having been by this change of direction in some degree curved, the new ones which were commenced on each side of it, by being built every where parallel to it, partook of the same curvature. But the bees did not relish such approaches to the "line of beauty," and exerted themselves to bring their buildings again into the regular form.

In consequence of several irregularities which they wished to correct, the younger Huber has seen bees depart from their usual practice, and at once lay on a spar two foundation walls not in the same line. They could consequently neither be enlarged without obstructing both, nor from their position could the edges unite had they been prolonged. The little architects, however, had recourse to a very ingenious contrivance: they curved the edges of the two combs, and brought them to unite so neatly that they could be both prolonged in the same line with ease; and when carried to some little distance, their surface becane quite uniform and level.

" Having seen bees," says the elder Huber, " work both up and down, I wished to try to investigate whether we could compel them to construct their vol. IV. 
combs in any other direction. We endeavoured to puzzle them with a hive glazed above and below, so that they had no place of support but the upright sides of their dwelling; but, betaking themselves to the upper angle, they built their combs perpendicular to one of these sides, and as regularly as those which they usually build under a horizontal surface. The foundations were laid on a place which does not serve naturally for the base, yet, except in the difference of direction, the first row of cells resembled those in ordinary hives, the others being distributed on both faces, while the bottoms alternately corresponded with the same symmetry. I put the bees to a still greater trial. As they now testified their inclination to carry their combs, by the shortest way, to the opposite side of the hive (for they prefer uniting them to wood, or a surface rougher than glass), I covered it with a pane. Whenever this smooth and slippery substance was interposed between them and the wood, they departed from the straight line hitherto followed, and bent the structure of their comb at a right angle to what was already made, so that the prolongation of the extremity might reach another side of the hive, which had been left free.

"Varying this experiment in several ways, I saw the bees constantly change the direction of their combs, when I presented to them a surface too smooth to admit of their clustering on it. They always sought the wooden sides. I thus compelled them to eurve the combs in the strangest shapes, by placing a pane at a certain distance from their edges. These results indicate a degree of instinct truly wonderful. They denote even more than instinct: for glass is not a substance against which bees can be warned by nature. In trees, their natural abode, there is nothing that resembles it, or with the same 
polish. The most singular part of their proceeding is changing the direction of the work before arriving at the surface of the glass, and while yet at a distance suitable for doing so. Do they anticipate the inconvenience which would attend any other mode of building? No less curious is the plan adopted by the bee for producing an angle in the combs: the wonted fashion of their work, and the dimensions of the cells, must be altered. Therefore, the cells on the upper or convex side of the combs are enlarged; they are constructed of three or four times the width of those on the opposite surface. How can so many insects, occupied at once on the edges of the combs, concur in giving them a common curvature from one extremity to the other? How do they resolve on establishing cells so small on one side, while dimensions so enlarged are bestowed on those of the other? And is it not still more singular, that they have the art of making a correspondence between cells of such reciprocal discrepance? The bottom being common to both, the tubes alone assume a taper form. Perhaps no other insect has afforded a more decisive proof of the resources of instinct, when compelled to deviate from the ordinary course.

"But let us study them in their natural state, and there we shall find that the diameter of their cells must be adapted to the individuals which shall be bred in them. The cells of males have the same figure, the same number of lozenges and sides as those of workers, and angles of the same size. Their diameter is $3 \frac{x}{3}$ lines, while those of workers are only $2 \frac{7}{5}$.

"It is rarely that the cells of males occupy the higher part of the combs. They are generally in the middle or on the sides, where they are not isolated. The manner in which they are surrounded by other cells alone can explain how the transition 
in size is effected. When the cells of males are to be fabricated under those of workers, the bees make several rows of intermediate cells, whose diameter augments progressively, until gaining that proportion proper to the cells required; and, in returning to those of workers, a lowering is observed in a manner corresponding.

"Bees, in preparing the cells of males, previously establish a block or lump of wax on the edge of their comb, thicker than is usually employed for those of workers. It is also made higher, otherwise the same order and symmetry could not be preserved on a larger scale.

"Several naturalists notice the irregularities in the cells of bees as so many defects. What would have been their astonishment had they observed that part of them are the result of calculation? Had they followed the imperfection of their organs, some other means of compensating them would have been granted to the insects. It is much more surprising that they know how to quit the ordinary routc, when circumstances demand the construction of cnlarged cells; and, after building thirty or forty rows of them, to return to the proper proportions from which they have departed, by successive reductions. Bees also augment the dimensions of their cells when there is an opportunity for a great collection of honey. Not only are they then constructed of a diameter much exceeding that of the common cells, but they are elongated throughout the whole space admitting it. A great portion of irregular comb contains cells an inch, or even an inch and a half, in depth.

"Bees, on the contrary, sometimes are induced to shorten their cells. When wishing to prolong an old comb, whose cells have received their full dimensions, they gradually reduce the thickness of its edges, by gnawing down the sides of the cells, until they 
restore it to its original lenticular form. They add a waxen block around the whole circumference, and on the edge of the comb construct pyramidal bottoms, such as those fabricated on ordinary occasions. It is a certain fact, that a comb never is extended in any direction unless the bees bave thinned the edges, which are diminished throughout a sufficient space to remove any angular projection.

"The law which obliges these insects partly to de-molish the cells on the edges of the comb before enlarging it, unquestionably demands more profound investigation. How can we account for instinct leading them to undo what they have executed with the utmost care? The wonted regular gradation, which may be necessary for new cells, subsists among those adjoining the edges of a comb recently constructed. But afterwards, when those on the edge are deepened like the cells of the rest of the surface, the bees no longer preserve the decreasing gradation which is seen in the new combs." "*

\section{The Finishing of the Cells.}

While the cells are building, they appear to be of a dull white colour, soft, even, though not smooth, and translucent: but in a few days they become tinged with yellow, particularly on the interior surface; and their edges, from being thin, uniform, and yielding, become thicker, less regular, more heavy, and so firm that they will bend rather than break. New combs break on the slightest touch. There is also a glutinous substance observable around the orifices of the yellow cells, of reddish colour, unctuous, and odoriferous. Threads of the same substance are applied all around the interior of the cells, and at the summit of their angles, as if it were for the purpose

* Huber on Bees, p. 391.

vOL. IV. 
of binding and strengthening the walls. These yellow cells also require a much higher temperature of water to melt them than the white ones.

It appeared evident, therefore, that another substance, different from wax, had been employed in varnishing the orifices and strengthening the interior of the cells. M. Huber, by numerous experiments, ascertained the resinous threads lining the cells, as well as the resinous substance around their orifice, to be propolis; for he traced them, as we mentioned in our account of propolis, from the poplar buds where they collected it, and saw them apply it to the cells; but the yellow colour is not imparted by propolis, to which it bears no analogy. We are, indeed, by no means certain what it is, though it was proved by experiment not to arise from the heat of the hives, nor from emanations of honey, nor from particles of pollen. Perhaps it may be ascribed to the bees rubbing their teeth, feet, and other parts of their body on the surfaces where they seem to rest; or to their tongue (haustellum) sweeping from right to left like a fine pliant pencil, when it appears to leave some sprinkling of a transparent liquid.

Beside painting and varnishing their cells in this manner, they take care to strengthen the weaker parts of their edifice by means of a mortar composed of propolis and wax, and named pissoceros* by the ancients, who first observed it, though Réaumur was somewhat doubtful respecting the existence of such a composition. We are indebted to the shrewd observations of Huber for a reconcilement of the Roman and the French naturalists. The details which he has given of his discovery are perhaps the most interesting in his delightfinl book.

"Soon," he says, " after some new combs had been

- From two fireek worda, signifying pitch and wax. 
finished in a hive, manifest disorder and agitation prevailed among the bees. They seemed to attack their own works. The primitive cells, whose structure we had admired, were scarcely recognizable. Thick and massy walls, heavy, shapeless pillars, were substituted for the slight partitions previously built with such regularity. The substance had changed along with the form, being composed apparently of wax and propolis. From the perseverance of the workers in their devastations, we suspected that they proposed some useful alteration of their edifices; and our attention was directed to the cells least injured. Several were yet untouched; but the bees soon rushed precipitately on them, destroyed the tubes, broke down the wax, and threw all the fragments about. But we remarked, that the bottom of the cells of the first row was spared; neither were the corresponding parts on both faces of the comb demolished at the same time. The bees laboured at them alternately, learing some of the natural supports, otherwise the comb would have fallen down, which was not their object: they wished, on the contrary, to provide it a more solid base, and to secure its union to the vault of the hive, with a substance whose adhesive properties infinitely surpassed those of wax. The propolis employed on this occasion had been deposited in a mass over a cleft of the hive, and had hardened in drying, which probably rendered it more suitable for the purpose. But the bees experienced some difficulty in making any impression on it; and we thought, as also had appeared to $\mathbf{M}$. de Réaumur, that they softened it with the same frothy matter from the tongue which they use to render wax more ductile.

"We very distinctly observed the bees mixing fragments of old wax with the propolis, kneading the two substances together to incorporate them; and the compound was employed in rebuilding the cells 
that had been destroyed. But they did not now follow their ordinary rules of architecture, for they were occupied by the solidity of their edifices alone. Night intervening, suspended our observations, but next morning confirmed what we had seen.

"We find, therefore, that there is an epoch in the labour of bees, when the upper foundation of their combs is constructed simply of wax, as Riaumur believed; and that afier all the requisite conditions have been attained, it is converted to a mixture of wax and propolis, as remarked by Pliny so many ages before us. Thus is the apparent contradiction between these two great naturalists explained. But this is not the utmost extent of the foresight of these insects. When they have plenty of wax, they make their combs the full breadth of the hive, and solder them to the glass or wooden sides, by structures more or less approaching the form of cells, as circumstances admit. But should the supply of wax fail before they have been able to give sufficient diameter to the combs whcse edges are rounded, large intervals remain between them and the upright sides of the hive, and they are fixed only at the top. Therefore did not the bees provide against it, by constructing great pieces of wax mixed with propolis, in the intervals, they might be borne down by the weight of the honey. These pieces are of irregular shape, strangely hollowed out, and their cavities void of symmetry." ${ }^{*}$

It is remarked by the lively Abbé La Pluche, that the foundations of our houses sink with the earth on which they are built, the walls begin to stoop by degrees, they nod with age, and bend from their perpendicular; -lodgers damage ercrything, and time is continually introducing some new decay. The mansions of bees, on the contrary, grow stronger the

Huber on Bees, p. 415. 
oftener they change inhabitants. Every bee-grub, before its metamorphosis into a nymph, fastens its skin to the partitions of its cell, but ii such a manner as to make it correspond with the lines of the angles, and without in the least disturbing the regularity of the figure. During summer, accordingly, the same lodging may serve for three or four grubs in succession; and in the ensuing season it may accommodate an equal number. Each grub never fails to fortify the panels of its chamber by arraying them with its spoils and the contiguous cells receive a similar augmentation from its brethren.* Réaumur found as many as seven or eight of these skins spread over one another: so that all the cells being incrusted with six or seven coverings, well dried and cemented with propolis, the whole fabric daily acquires a new degree of solidity.

It is obvious, however, that by a repetition of this process the cell might be rendered too contracted; but in such a case the bees know well how to proceed, by turning the cells to other uses, such as magazines for bee-bread and honey. It has been remarked, however, that in the hive of a new swarm, during the months of July and August, there are fewer small bees or nurse-bees, than in one that has been tenanted four or five years. The workers, indeed, clean out the cell the moment that a young bee leaves its cocoon, but they never detach the silky film which it has previously spun on the walls of its cell. But though honey is deposited after the young leave the cells, the reverse also happens; and accordingly when bees are bred in contracted cells, they are by necessity smaller, and constitute, in fact, the important class of nurse-bees.

We are not disposed, however, to go quite so far as an American periodical writer, who says, "Thus we

* Spectacle de la Nature, vol. i. 
see that the contraction of the cell may diminish the size of a bee, even to the extinction of life, just as the contraction of a Chinese shoe reduces the foot even to uselessness." We know, on the contrary, that the queen bee will not deposit eggs in a cell either too small or two large for the proper rearing of the young. In the case of large cells, M. Huber took advantage of a queen that was busy depositing the eggs of workers, to remove all the common cells adapted for their reception, and left only the large cells appropriated for males. As this was done in June, when bees are most active, he expected that they would have immediately repaired the breaches he had made, but to his great surprise they did not make the slightest movement for that purpose. In the meanwhile the queen, being oppressed by her eggs, was obliged to drop them about at random, preferring this to depositing them in the male cells which she knew to be too large. At length she did deposit six eggs in the large cells, which were hatched, as usual, three days after. The nurse-bees, however, seemed to be aware that they could not be reared there, and, though they supplied them with food, did not attend to them regularly. M. Huber found that they had been all removed from the cells during the night, and the business both of laying and nursing was at a complete stand for twelve days, when he supplied them again with a comb of small ceils, which the qucen almost immediately filled with eggs, and in some cells she laid five or six.

The architecture of the hive, which we have thus detailed, is that of bees receiving the aid of human care, and having external coverings of a convenient form, prepared for their reception. In this country bees are not found in a wild state; though it is not

* North American Rev., Oct. 1828 , p. 355. 
uncommon for swarms to stray from their proprietors. But these stray swarms do not spread colonies through our woods, as they are said to do in America. In the remoter parts of that continent there are no wild bees. They precede civilization; and thus when the Indians observe a swarm they say " the white man is coming." There is evidence of bees having abounded in these islands, in the earlier periods of our history; and Ireland is particularly mentioned by the Venerable Bede as being " rich in milk and honey." The hive bee has formed an object of economical culture in Europe at least for two thousand years; and Varro describes the sort of hives used in his time, 1870 years ago. We are not aware, however, that it is now to be found wild in the milder clime of Southern Europe, any more than it is in our own island.

The wild bees of Palestine principally hived in rocks. "He made him," says Moses, "to suck honey out of the rock." $\uparrow$ " With honey out of the rock," says the Psalmist, "should I have satisfied thee." + In the caves of Salsette and Elephanta, at the present day, they hive in the clefts of the rocks, and the recesses among the fissures, in such numbers, as to become very troublesome to visiters. Their nests hang in innumerable clusters.

We are told of a little black stingless bee found in the island of Gaudaloupe, which hives in hollow trees or in the cavities of rocks by the sea side, and lays "up honey in cells about the size and shape of pigeons' eggs. These cells are of a black or deep violet colour, and so joined together as to leave no space between them. They hang in clusters almost like a bunch of grapes." The following are mentioned by Lindley as indigenous to Brazil. "On an

* "Hibernia dives lactis ac mellis insula."-Beda, Hist. Ee. cles. i., 7 . $\dagger$ Deut. xxxii. 13.

|| Forbes, Orien. Mem. i. T Amer. Q. Rev., iii. p. $\mathbf{3 8 3}$, 
excursion towards Upper Tapagippe," says he, " and skirting the dreary woods which extend to the interior, I observed the trees more loaded with bees' nests than even in the neighbourhood of Porto Seguro. They consist of a ponderous shell of clay cemented similarly to martin's nests, swelling from high trees about a foot thick, and forming an oval mass full two feet in diameter. When broken, the wax is arranged as in our hives, and the honey abundant."

Captain Basil Hall found in South America the hive of a honey-bee very difierent from the Brazilian, but nearly allied to, if not the same, as that of Guadaloupe. " "The hive we saw opened," he says, " was only partly filled, which cnabled us to see the economy of the interior to more advantage. The honey is not contained in the elegant hexagonal cells of our hives, but in wax-bags, not quite so large as an egg. These bags or bladders are hung round the sides of the hive, and appear about half fill; the quantity being probably just as great as the strength of the wax will bear without tearing. Those near the bottom, being better supported, are more filled than the upper ones. In the centre of the lower part of the hive we observed an irregularly-shaped miss of comb, furnished with cells like those of our bees, all containing young ones in such an advanced state, that, when we broke the comb, and let them out, they flew merrily away."

Clavigero, in his History of Mexico, evidently deseribing the same species of bee, says it abounds in Vucatan, and makes the honcy of Estabentum, the finest in the world, and which is taken every two months. He mentioned another species of bee, smaller in size, and also without a sting, which forms its nest of the shape of a sugarloaf, and as large or larger. These are suspended from trees, particularly

* Roy. Mill. Chron. quoted in Kirby and Spence. 
from the oak, and are much more populous than our common hives.

Wild honey-bees of some specics appear also to abound in Africa. Mr Park, in his second volume of travels, tells us that some of his associates imprudently attempted to rob a numerous hive of its honey, when the exasperated bees, rushing out to defend their property, attacked their assailants with great fury, and quickly compelled the whole company to fly.

At the Cape of Good Hope the bees themselves must be less formidable, or more casily managed, as their hives are sought for with avidity. Nature has there provided man with a singular and very efiicient assistant in a bird, most appropriately named the Honey-Guide (Indicator major, VieıLLot; Cu. culus indicator, Latнaм). The honey-guide, so far from being alarmed at the presence of man, appears anxious to court his acquaintance, and flits from tree to tree with an expressive note of invitation, the meaning of which is well known both to the colonists and the Hottentots. A person invited by the honey-guide seldom refuses to follow it onwards till it stops, as it is certain to do, at some hollow tree containing a bee-hive, usually well stored with honey and wax. It is probable that the bird finds itself inadequate to the attack of a legion of bees, or to penetrate into the interior of the hive, and is thence led to invite an agent more powerful than itself. The person invited, indeed, always leaves the bird a share of the spoil, as it would be considered sacrilege to rob it of its due, or in any way to hurt so useful a creature.

The Americans, who have not the African honeyguide, employ several well-known methods to track bees to their hives. One of the mcst oommon though ingenious modes, is to place a piece of bee-

roL. $1 \mathrm{~V}$. 
bread on a flat surface, a tile for instance, surrounding it with a circle of wet white paint. The bee, whose habit it is always to alight on the edge of any plane, has to travel through the paint to reach the bee-bread. When, therefore, she flies off, the observer can track her by the white on her body. The same operation is repeated at another place, at some distance from the first, and at right angles to the beeline just ascertained. The position of the hive is easily determined, for it lies in the angle made by the intersection of the bee-lines. Another method is described in the Philosophical Transactions for 1721 . The bee-hunter decoys, by a bait of honey, some of the bees into his trap, and when he has secured as many as he judges will suit his purpose, he encloses one in a tube, and, letting it fly, marks its course by a pocket compass. Departing to some distance, he liberates another, observes its course, and in this manner determines the position of the hive, upon the principle already detailed. These methods of beehunting depend upon the insect's habit of always flying in a right line to its home. Those who have read Cooper's tale of the 'Prairie' must well remember the expression of "lining a bee to its hive."

In reading these and similar accounts of the bees of distant parts of the world, we must not conclude that the descriptions refer to the same species as the common honey-bee. There are nummerous species of social bees which, while they differ in many circumstances, agree in the practice of storing up honey, in the same way as we have numerous species of the mason bee and of the humbie bee. Of the latter Mr Stephens enumerates no less than forty-two species indigenous to Britain. 


\section{Chapter Vil.}

Carpentry of Tree-Hoppers and saw-Flies.

The operations of an insect in boring into a leaf or a bud to form a lodgment for its eggs appear very simple. The tools, however, by which these effeets are performed are very complicated and curious. In the case of gall-flies (Cynips,) the operation itself is not so remarkable as its subsequent chemical effects. These effects are so different from any others that may be classed under the head of Insect Architecture, that we shall reserve them for the latter part of this volume-although, with reference to the use of galls, the protection of eggs and larvæ, they ought to find a place here. We shall, however, at present confine ourselves to those which simply excavate a nest, without producing a tumour.

The first of these insects which we shall mention is celebrated for its song, by the ancient Greek poets, under the name of $\mathrm{T}_{\boldsymbol{z} \tau \tau} b_{\hat{\xi}}$. The Romans called it Cicada, which we sometimes, but erroneously, translate "grasshopper;" for the grasshoppers belong to an entirely different order of insects. We shall, therefore, take the liberty of calling the Cicadæ, Treehoppers, to which the cuckoo-spit insect (Teltigonic spumaria, OLIV.) is allied; but there is only one of the true cicadre hitherto ascertained to be British, namely, the Cicadn homatodes (Liss.), which was taken in the New Forest, Hampshire, by Mr Daniel Bydder.

M. Réaumur was exceedingly anxious to study the economy of those insects; but they not being indigenous in the neighbourhood of Paris, he commis- 
sioned his friends to send him some from more southern latitudes, and he procured in this way specimens not only from the South of France and from Italy, but also from Egypt. From these specimens he has given the best account of them yet published; for though, as he tells us, he had never had the pleasure of sceing one of them alive, the more interesting parts of their structure can be studied as well in dead as in living specimens. We ourselves possess sevcral specimens from New Holland, upon which.we have verified some of the more interesting observations of $\mathrm{R}$ aumur.

Virgil tells us, that in his time "the cicadæ burst the very shrubs with their querulous music;" * but we may well suppose that he was altogether unacquainted with the singular instrument by means of which they can actually (not poetically) cut grooves in the branches they select for depositing their eggs. It is the male, as in the case of birds, which fills the woods with his song; while the female, though mute, is no less interesting to the naturalist on account of her curious ovipositor. This instrument, like all those with which insects are furnished by nature for cutting, notching, or piercing, is composed of a horny substance, and is also considerably larger than the size of the tree-hopper would proportionally indicate. It can on this account be partiaily examined without a microscope, being, in some of the larger species, no less than five linest in length.

The ovipositor or auger (laríre) as Réaumur calls it, is lodged in a sheath which lies in a groove of the terminatung ring of the belly. It requires only a very slight pressure to cause the instrument to protrude from its sheath, when it appears to the naked eye to be of equal thickness throughout except at the point,

- Cantu querulæ rumpent arbusta cicadæ. Georg. iii. 328 .

t A line is abont the twelfth part of an inch. 
where it is somewhat enlarged and angular, and on both sides finely indented with teeth. A more minute examination of the sheath demonstrates that it is composed of two horny pieces slightly curved, and ending in the form of an elongated spoon, the concave part of which is adapted to receive the convex end of the ovipositor.

When the protruded instrument is further examined with a microscope, the denticulations, nine in in umber on each side, appear strong, and arranged with great symmetry, increasing in fineness towards the point, where there are three or four very small ones, beside the nine that are more obvious. The magnifier also shews that the instrument itself, which appeared simple to the naked eye, is in fact composed of three different pieces, two exterior armed with the teeth before-mentioned, denominated by $\mathbf{R}$ iamur files, (limes), and another pointed like a lancet, and not denticulated. The denticulated pieces moreover are capable of being moved forwards and backwards, while the centre one remains stationary, and as this motion is effected by pressing a pin or the blade of a knife over the muscles on either side at the origin of the ovipositor, it may be presumed that those muscles are destined for producing similar movements when the insect requires them. By means of a finely pointed pin carefully introduced between the pieces, and pushed very gently downwards, they may be, with no great difficulty, separated in their whole ex tent.

The contrivance by which those three pieces are held united, while at the same time the two files can be easily put in'motion, are similar to some of our own mechanical inventions, with this difference, that no human workman could construct an instrument of this description so small, fine, exquisitely polished, and fitting so exactly. We should have been apt to VOL. IV. 
form the grooves in the central piece, whereas they are scooped out in the handles of the files, and play upon two projecting ridges in the central piece, by which means this is rendered stronger. M. Réaumur discovered that the best manner of showing the play of this extraordinary instrument is to cut it off with a pair of scissors near its origin, and then, taking it between the thumb and the finger at the point of section, work it gently to put the files in motion.
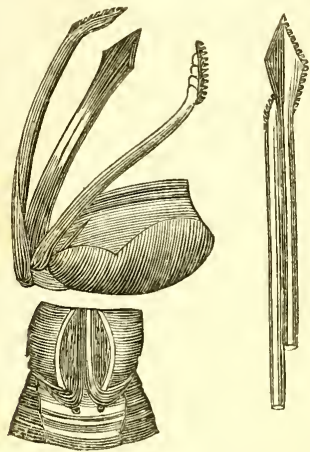

Ovipositors, with files, of Tree-lopper, magnified.

Beside the muscles necessary for the movement of the files, the handle of each is terminated by a curve of the same hard horny substance as itself, which not only furnishes the muscles with a sort of lever, but serves to press, as with a spring, the two files close to the central picee, as is shewn in the lower figure.

M. Pontedera, who studied the economy of the tree-hoppers with some care, was anxious to see the 
insect itself make use of the ovipositor in forming grooves in wood, but found that it was so shy and easily alarmed, that it tonk to flight whenever he approached; a circumstance of which Réaumur takes advantage, to soothe his regret that the insects were not indigenous in his neighbourhood. But of their workmanship when completed, he had several specimens sent to him from Province and Languedoc by the Marquis de Caumont.

The gall-flies, when about to deposit their eggs, select growing plants and trees; but the tree-hoppers on the contrary, make choice of dead, dried branches for the mother seems to be aware that moisture would injure her progeny. The branch, commonly a small one, in which eggs have been deposited, may be recognised by being covered with little oblong elevations caused by small splinters of the wood, detached at one end, but left fixed at the other by the insect. These elevations are for the most part in a line, rarely in a double line, nearly at equal distances from each other, and form a lid to a cavity in the wood about four lines in length, containing from

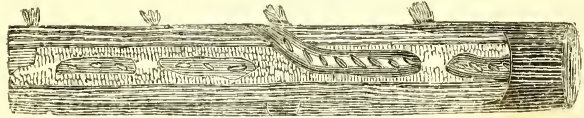

Excavations for eggs of Tree-hopper, with lids raised.

four to ten eggs. It is to be remarked, that the insect always_selects a branch of such dimensions, that it can get at the pith, not because the pith is more easily bored, for it does not penetrate into it at all, but to form a warm and safe bed for the eggs. II. Pontedera says, that when the eggs have been deposited, the insect closes the mouth of the hole with a gum capable of protecting them from the weather; but M. Réaumur thinks this only a fancy, as 
out of a great number which he examined, lie could discover nothing of the kind. Neither is such a protection wanted; for the woody splinters above mentioned furnish a very good covering.

The grubs hatched fiom these eggs (of which, M. Pontedera says, one female will deposit fiom five to seven hundred) issue from the same holes through which the eggs have been introduced, and betake themselves to the ground to feed on the roots of plants. They are not transformed into chrysalides, but into active nymphs, remarkable for their fore limbs, which are thick, strong, and furnished with prongs for digging; and when we are told by Dr Le Fevre, that they make their way easily into hard stiff clay, to the depth of two or three feet, we perceive how necessary to them such a conformation must be.

\section{Saw-Flies.}

An instrument for cutting grooves in wood, still more ingeniously contrived than that of the treehopper, was first observed by Valisnieri, an eminent Italian naturalist, in a fore-winged fly, most appropriately denominated by M. Réaumur the sau-fly (Tenthredo), of which many sorts are indigenous to Great Britain. The grubs from which those flies originate are indeed but two well known, as they frequently strip our rose, gooseberry, raspberry, and red currant trees of their leaves, and are no less destructive to birch, alder and willows; while turnips and wheat suffer still more seriously by thcir rarages. These grubs may readily be distinguished from the caterpillars of moths and butterflies, by having from sixteen to twenty-eight feet, by which they usually hang to the leaf they feed on, while they coil up the hinder part of their body in a spiral ring. The perfect flies are distinguished by four transparent wings; and 
some of the most common have a flat body of a yellow or orange colour, while the head and shoulders are black.

In order to see the ovipositor to which we shall for the present turn our chief attention, a female sawfly nust be taken, and her belly gently pressed, when a narrow slit will be observed to open at some distance from the anus, and a short, pointed, and somewhat curved body, of a brown colour and horny substance, will be protruded. The curved plates which form the sides of the slit, are the termination of the sheath, in which the instrument lies concealed till it is wanted by the insect. The appearance of this instrument, howerer, and its singular structure, cannot be well understood without the aid of a microscope.

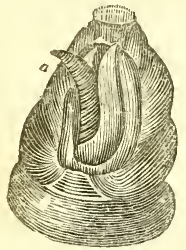

a. Ovipositor of Sazv-fiy, protruded from its Sheath, magniefid.

The instrument thus brought into view, is a very finely contrived saw, made of horn, and adapted for penetrating branches and other parts of plants where the eggs are to be deposited. The ovipositor saw of the insect is much more complicated than any of those employed by our carpenters. The teeth of our saws are formed in a line, but in such a manner as to cut in two lines parallel to, and at a small distance from each other. This is effected by slightly bending the points of the alternative teeth right and left, so that one half of the whole teeth 
stand a little to the right, and the other half a little to the left. The distance of the two parallel lines thus formed is called the course of the saw, and it is only the portion of wood which lies in the course that is cut into saw-dust by the action of the instrument. It will follow, that in proportion to the thinness of a saw there will be the less destruction of wood which may be sawed. When cabinet-makers have to divide valuable wood into very thin leaves. they accordingly employ saws with a narrow course; while sawyers who cut planks, use one with a broad course. The ovipositor saw being extremely fine, does not require the teeth to diverge much, but from the manner in which they operate, it is requisite that they should not stand like those of our saws in a straight line. The greater portion of the edge of the instrument, on the contrary, is towards the point somewhat concave, similar to a scythe, while towards the base it becomes a little convex, the whole edge being nearly the shape of an Italic $f$.

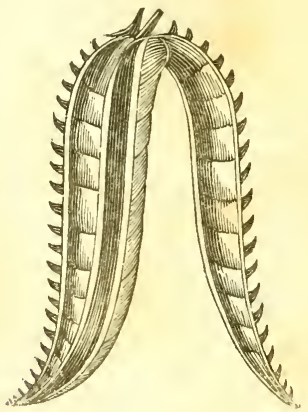

Ovipositor-saw of $S a w-f y$, with rasps shewn in the cross lincs. 
The ovipositor-saw of the fly is put in motion in the same way as a carpenter's hand-saw, supposing the tendons attached to its base to form the handle, and the muscles which put it in motion to be the hand of the carpenter. But the carpenter can only work one saw at a time, whereas each of these flies is furnished with two, equal and similar, which it works at the same time-one being advanced and the other retracted alternately. The secret, indeed, of working more saws than one at once is not unknown to our mechanics; for two or three are sometimes fixed in the same frame. These, however, not only all move upwards and downwards simultaneously, but cut the wood in different places; while the two saws of the ovipositor work in the same cut, and, consequently, though the teeth are extremely fine, the effect is similar to a saw with a wide set.

It is important, seeing that the ovipositor-saws are so fine, that they be not bent or separated while in operation-and this, also, nature has provided for, by lodging the backs of the saws in a groove, formed by two membranous plates, similar to the structure of a clasp-knife. These plates are thickest at the base, becoming gradually thinner as they approach the point which the form of the saws require. According to Vallisnieri, it is not the only use of this apparatus to form a back for the saws, he having discovered, between the component membranes, two canals, whieh he supposes are employed to conduct the eggs of the insect into the grooves which it has hollowed out for them.*

'The teeth of a carpenter's saw, it may be remarked, are simple, whereas the teeth of the ovipositor saw are themselves denticulated with fine teeth. The latter, also, combines at the same time the properties of a saw and of a rasp or file. So far as we are aware,

* Réaumur, Mem. des Insectes, v. p. iii. 
these two properties have never been combined in any of the tools of our carpenters. The rasping part of the oripositor, however, is not constructed like our rasps, with short teeth thickly studded together, but has teeth almost as long as those of the saw, and placed contiguous to them on the back of the instrument, resembling in their form and setting the teeth of a comb, as may be seen in the figure. Of course, such observations are conducted with the aid of a microscope.

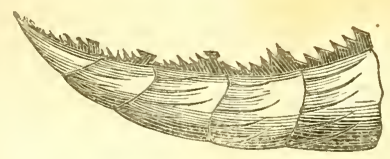

Portion of Saw-fiy's comb-toothed rasp, and saw.

When a female saw-fly has selected the branch of a rose-tree, or any other, in which to deposit her eggs, she may be seen bending the end of her belly inwards, in form of a crescent, and protruding her saw, at the same time, to penetrate the bark or wood. She rhaintains this recurved position so long as she works in deepening the groove; but when she has attained the depth required, she unbends her body into a straight line, and in this position works upon the place lengthways, by applying the saw more horizontally. When she has rendered the groove as large as she wishes, the motion of the tendons ceases, and an egg is placed in the carity. The saw is then withdrawn into the sheath for about two-thirds of its length, and at the same moment, a sort of frothy liquid, similar to a lather made with soap, is dropped over the egg, either for the purpose of glueing it in its place, or sheathing it from the action of the juices of the tree. She proceeds in the same manner in sawing out a second groove, and so on in 
succession till she has deposited all her eggs, sometimes to the number of twenty-four. The grooves are usually placed in a line, at a small distance from one another, on the same branch; but sometimes the mother-fly shifts to another, or to a different part of the branch, when she is either scared or finds it unsuitable. She commonly, also, takes more than one day to the work, notwithstanding the superiority of her tools, Reaumur has seen a saw-fly make six grooves in succession, which occupied her about ten hours and a half.

The grooves, when finished, have externally little elevation above the level of the bark, appearing like the puncture of a lancet in the human skin; but in the course of a day or two the part becomes first brown and then black, while it also becomes more and more elevated. This increased elevation is not owing to the growth of the bark, the fibres of which, indeed, have been destroyed by the ovipositor saw, but to the actual growth of the egg; for, when a newlaid egg of the saw-fly is compared with one which has been several days enclosed in the groove, the latter will be found to be very considerably the larger. This growth of the egg is contrary to the analogy observable in the eggs of birds, and even of most other insects; but it has its advantages. As it continues to increase, it raises the bark more and more, and consequently widens, at the same time, the slit at the entrance; so that, when the grub is hatched, it finds a passage ready for its exit. The mother-fly seems to be aware of this growth of her eggs, for she takes care to deposit them at such distances as may prevent their disturbing one another by their developement.

Another species of saw-fly, with a yellow body and deep violet-coloured wings, which also selects the rose-tree, deposits her eggs in a different manner. Instead of making a groove for each egg, like the 
preceding, she forms a large single groove, sufficient for about two dozen eggs. These eggs are all arranged in pairs, forming two straight lines parallel to the sides of the branch. The eggs, however, though thus deposited in a common groove, are carefully kept each in its place; for a ridge of the wood is left to prevent those on the right from touching those on the left-and not only so, but between each egg of a row a thin partition of wood is left, forming a shallow cell.

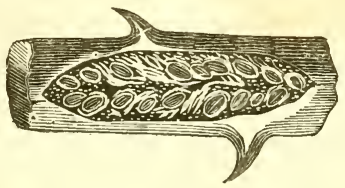

Nest of eggs of Saw-fiy, in rose tree.

The edges of this groove, it will be obvious, must be farther apart than those which only contain a single egg, and, in fact, the whole is open to inspection; but the eggs are kept from falling out, both by the frothy glue before mentioned, and by the walls of the cells containing them. They were observed also, by Vallisnieri, to increase in size like the preceding. 


\section{Chapter Vili.}

Leaf-rolling caterpillars.

THE labours of those insect-architects, which we have endeavoured to describe in the preceding pages, have been chiefly those of mothers to form a secure nest for their eggs, and the young hatched from them, during the first stage of their existence. But a much more numerous, and not less ingenious class of architects, may be found among the newly hatched insects themselves, who, untaught by experience, and altogether unassisted by previous example, manifest the most marvellous skill in the construction of tents, houses, galleries, covert-ways, fortifications, and even cities, not to speak of subterranean caverns and subaqueous apartments, which no human art could rival.

The caterpillars which are familiarly termed leafrollers, are perfect hermits. Each lives in a cell, which it begins to construct almost immediately after it is hatched; and the little structure is at once a house which protects the caterpillar from its enemies, and a store of food for its subsistence, while it remains shut up in its prison. But the insect only devours the inner folds. The art which these caterpillars exercise, although called into action but once, perhaps, in their lives, is perfect. They accomplish their purpose with a mechanical skill, which is remarkable for its simplicity and unerring success. The art of rolling leaves into a secure and immovable 
cell may not appear very difficult;-nor would it be so if the caterpillars had fingers, $c$ any parts which were equiralent to those delicate and admirable natural instruments with which man accomplishes his most elaborate works. And yet the human fingers could not roll a rocket-case of paper more regularly than the caterpillar rolls his house of leaves. A leaf is not a very easy substance to roll. In some trees it is rery brittle. It has also a natural elasticity,a disposition to spring back if it be bent, - which is caused by the continuity of its threads, or nervures This elasticity is speedily overcome by the ingenuity with which the caterpillar works; and the leaf is thus retained in its artificial position for many weeks, under every variety of temperature. We will examine, in detail, how these little leaf-rollers accomplish their task.

One of the most common as well as the most simple fabrics constructed by caterpillars, may be discovered during summer on almost every kind of bush and tree. We shall take as examples those which are found on the lilac, and on the oak.

A small but very pretty chocolate coloured moth,

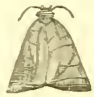

Lulac tree Moth. (Lazotania Ribcana, Stephens?)

abundant in every garden, but not readily seen from its frequently alighting on the ground which is so nearly of its own colour, deposits its eggs on the leaves of the lilac, and of some other trees, appropriating a leaf to each egg. As soon as the caterpillar is hatched, it begins to secure itself from birds and predatory insects by rolling up the lilac leaf into 
the form of a gallery, where it may feed in safety. We have repeatedly seen one of them when just escaped from the egg, and only a few lines long, fix several silk threads from one edge of a leaf, to the other, or from the edge to the mid-rib. Then going to the middle of the space, he shortened the threads by bending them with his feet, and consequently pulled the edges of the leares into a circular form; and he retained them in that position by glueing down each thread as he shortened it. In their younger state, those caterpillars seldom roll more than a small portion of the leaf; but when farther adranced, they unite the two edges together in their whole extent, with the exception of a small opening at one end, by which an exit may be made in case of need.

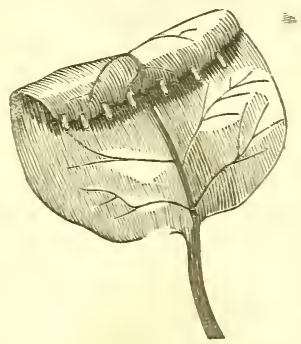

Nest of a Lilac-leaf Roller.

Another species of caterpillar closely allied to this, rolls up the lilac-leaves in a different form, beginning at the end of a leaf, and fixing and pulling its threads till it gets it nearly into the shape of a scroll of parchment. To retain this form more securely, it is voL. IV. 
not contented, like the former insect, with threads fixed on the inside of the leaf; but has also recourse to a few cables which it weaves on the outside

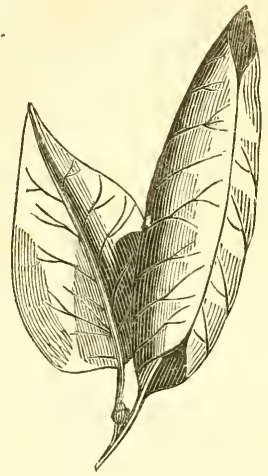

Another Nest of Lilac-tree Rollers.

Another species of moth allied to the two preceding, is of a pretty green colour, and lays its eggs

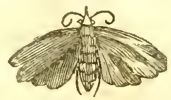

Small green Oak-moth. (Tortrix Viridana.)

upon the leaves of the oak. This caterpillar folds them up in a similar manner, but with this difference, that it works on the under surface of the leaf, pulling the edge downwards and backwards, instead of forwards and upwards. This species is very abundant, 


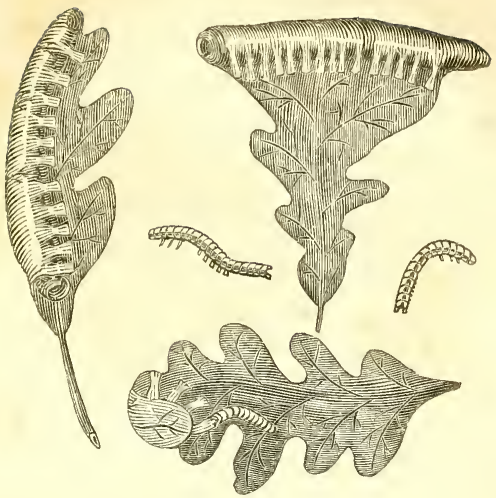

Nests of ouk-leuf rolling caterpillurs.

and may readily be found as soon as the leaves expand. In June, when the perfect insect has appeared, by beating a branch of an oak, a whole shower of these pretty green moths may be shook into the air.

Among the leaf-rolling caterpillars, there is a small dark-brown one, with a black head and six feet, very common in gardens on the currant-bush, or the leaves of the rose-tree. (Lozotonia Rosana, Stephens.) It is exceedingly destructive to the flower-buds. The eggs are deposited in the summer, and probably also in the autumn or in spring, in little oval or circular patches of a green colour. The grub makes its appearance with the first opening of the leaves of whose structure in the half-expanded state it takes advantage to construct its summer tent. It is not, like some of the other leaf-rollers, contented 
with a single leaf, but weaves together as many as there are in the bud where it may chance to have been hatched, binding their discs so firmly with silk, that all the force of the ascending sap, and the increasing growth of the leaves cannot break through; a farther expansion is of course prevented. The little inhabitant in the mean while banquets securely on the partitions of its tent, eating door-ways from one apartment into another, through which it can escape in case of danger or disturbance.

The leafits of the rose, it may be remarked, expand in nearly the same manner as a fan, and the opera. tions of this ingenious little insect retain them in the form of a fan nearly shut. Sometimes, however, it is not contented with one bundle of leafits, but by means of its silken cords unites all which spring from the same bud into a rain-proof canopy, under the protection of which it can feast on the flower-bud, and prevent it from ever blowing.

In the instance of the currant leaves, the proceedings of the grub are the same, but it cannot unite the plaits so smoothly as in the case of the rose leafits, and it requires more labour also, as the nervures being stiff, demand a greater effort to bend them. When all the exertions of the insect prove unavailing in its endeavours to draw the edges of a leaf together, it bends them inwards as far as it can, and weaves a close web of silk over the open space between. This is well exemplified in one of the commonist of our leaf-rolling caterpillars, which may be found as early as February on the leaves of the nettle and the white archangel (Lamium album.) It is of a light dirty-green colour, spotted with black, and covered with a few hairs. In its young state it confines itself to the bosom of a small leaf, near the insertion of the leaf-stalk, partly bending the edges inwards, and covering in the interval with a silken 
curtain. As this sort of covering is not sufficient for concealment when the animal advances in growth, it abandons the base of the leaf for the middle, where it doubles up one side in a very secure and ingenious manner.

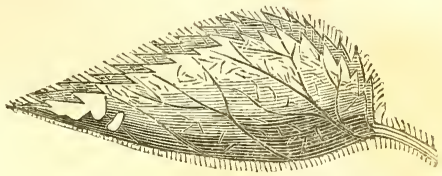

Nest of the nettle leaf-rolling Caterpillar.

We have watched this little architect begin and finish his tent upon a nettle in our study, the whole operation taking more than half an hour.* He began by walking over the plant in all directions, examining the leaves severally, as if to ascertain which was best fitted for his purpose by being pliable, and bending with the weight of his body. Having found one to his mind, he placed himself along the mid-rib, to the edge of which he secured himself firmly with the pro-legs of his tail; then stretching his head to the edge of the leaf, he fixed a series of parallel cables between it and the mid-rib, with another series crossing these at an acute angle. The position in which he worked was most remarkable, for he did not, as might have been supposed, spin his cables with his face to the leaf, but throwing himself on his back, which was turned towards the leaf, he hung with his whole weight by his first-made cables. This, by drawing them into the form of the curve, shortened them, and consequently pulled the edge of the leaf down towards the mid-rib. The weight of his body was not, however, the only power which he employed; for, using the anal pro-legs as a point of support, he exerted the 
whole muscles of his body to shorten his threads, and pull down the edge of the leaf. When he had drawn the threads as tight as he could, he held them till he spun fresh ones of sufficient strength to retain the leaf in the bent position into which he had pulled it. He then left the first series to hang loose while he shortened the fresh spun ones as before. This process was continued till he had worked down about an inch and a half of the leaf, as much as he deemed sufficient for his habitation. This was the first part of the architecture.

By the time he had worked to the end of the fold he had brought the edge of the leaf to touch the mid-rib; but it was only held in this position by a few of the last spun threads, for all the first spun ones hung loose within. Apparently aware of this, the insect protruded more than half of its body through the small aperture left at the end, and spun several bundles of threads on the outside precisely similar to those ropes of a tent which extend beyond the canvass, and are pegged into the ground. Unwilling to trust the exposure of his whole body on the outside, lest he should be seized by the first sand-wasp (odynerus) or sparrow which might descry him, he now withdrew to complete the internal portion of his dwelling, where the threads were hanging loose and disorderly. For this purpose he turned his head about, and proceeded precisely as he had done at the beginning of his task, but taking care to spin his new threads so as to leave the loose ones on the outside, and make his apartment smooth and neat. When he again reached the opposite end, he constructed there also a similar series of cables on the outside, and then withdrew to give some final touches to the interior.

It is said by Kirby and Spence,* that when these

* Introd. vol. i. p. 457. 
leaf-rolling insects find that the larger nervures of the leaves are so strong as to prevent them from bending, they "weaken it by gnawing it here and there half through." We have never observed the circumstance, though we have witnessed the process in some hundreds of instances; and we doubt the statement, from the careful survey which the insect makes of the capabilities of the leaf before the operation is begun. If she found upon examination that a leaf would not bend, she would reject it, as we have often seen happen, and pass to another.*

A species of leaf-roller, of the most diminutive size, merits particular mention, although it is not remarkable in colour or figure. It is without hair, of a greenish white, and has all the vivacity of the other leaf-rollers. Sorrel is the plant on which it feeds; and the manner in which it rolls a portion of the leaf is very ingenious.

The structure which it contrives is a sort of conical fyramid, composed of five or six folds lapped round each other. From the position of this little cone the caterpillar has other labours to perform, beside that of rolling the leaf. It first cuts across the leaf, its teeth acting as a pair of scissors; but it does not entirely detach this segment. It rolls it up very gradually, by attaching threads of silk to the plane surface of the leaf, as we have before seen; and then, having cut in a different direction, sets the cone upright, by weaving other threads, attached to the centre of the roll and the plane of the leaf, upon which it throws the weight of its body. This, it will be readily seen, is a somewhat complicated effort of mechanical skill. It has been minutely described by MI. Réaumur; but the following representation 
will perhaps make the process clearer than a more detailed account.
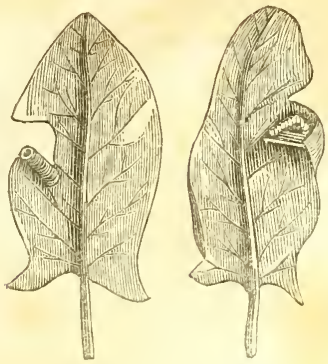

Lcaf-rolling Caterpillars of the Sorrel.

This caterpillar, like those of which we have already spoken, devours all the interior of the roller. It weaves, also, in the interior, a small and thin cocoon of white silk, the tissue of which is made compaet and close. It is then transformed into a chrysalis.

The caterpillars of two of our largest and liandsomest butterflies, the Painted Lady (Cynthia cardui, Stephens), and the Admirable, or Alderman of the London fly-fanciers ( $V$ anessa alalanta), are also leafrollers. The first selects the leares of the great spearthistle, and sometimes those of the stemless, or starthistle, which might be supposed rather difficult to bend; but the caterpillar is four times as large and strong as those which we have been hitherto describing. In some seasons it is plentiful; in others it is rarely to be met with: but the Admirable is seldom searce in any part of the country; and by 
examining the leaves of nettles which appear folded edge to edge, in July and August, the caterpillar may be readily found.

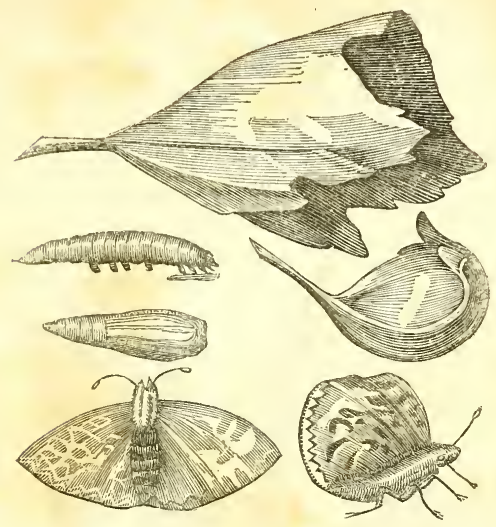

Nests of ihe IIesperia Malva, with Cuterpillar, Chrysalis, and Butterfies,

Another butterfly (Hesperia nulve) is met with on dry banks where mallows grow, in May, or even earlier, and also in August, but is not indigenous. The caterpillar, which is grey, with a black head, and four sulphur-coloured spots on the neck, folds around it the leaves of the mallow, upon which it feeds. There is nothing, however, peculiarly different in its proceedings from those above described; but the care with which it selects and rolls up one of the smaller leaves, when it is about to be transformed into a chrysalis, is worthy of remark; it

voL. $1 \mathrm{~V}$. 
joins it, indeed, so completely round and round, that it has somewhat the resemblance of an egg. Within this green cell it lies secure, till the time arrives when it is ready to burst its cerements, and trust to the quickness of its wings for protection against its enemies.

Among the nests of caterpillars which roll up parcels of leaves, we know none so well contrived as those which are found upon willows and a species of osier. The long and narrow leaves of these plants are naturally adapted to be adjusted parallel to each other; for this is the direction which
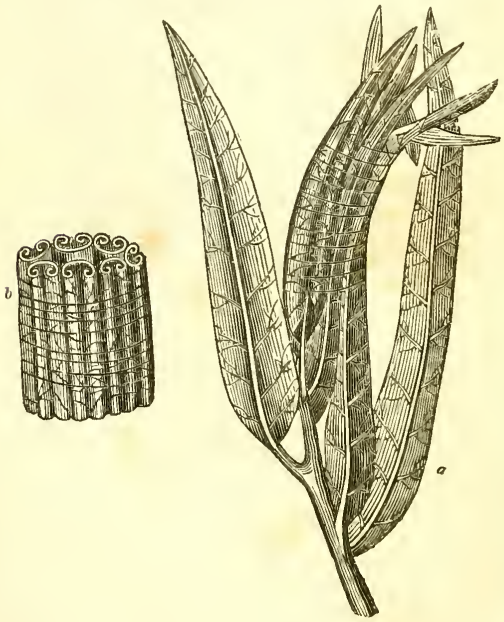

Nest of Willow-leaf Roll. 
they have at the end of each stalk, when they are not entirely developed. One kind of small smooth caterpillar (Tortrix chlorana), with sixteen feet, the under part of which is brown, and streaked with white, fastens these leaves together, and makes them up into parcels. There is nothing particularly striking in the mechanical manner in which it constructs them. It does precisely what we should do in a similar case: it winds a thread round those leaves which must be kept together, from a little above their termination to a very short distance from thcir extreme point; and as it finds the leaves almost constantly lying near each other, it has little difficulty in bringing them together, as is shewn in the cut, $a$.

The prettiest of these parcels are those which are made upon a kind of osier, the borders of whose leaves sometimes form columnar bundles before they are become developed. A section of these leaves has the appearance of fillagree work.-(See $b$, p. 170.)

A caterpillar which feeds upon the willow, and whose singular attitudes have obtained for it the trivial name of Ziczac, also constructs for itself an arbour of the leaves, by drawing them together in an ingenious manner. M. Roesel* has given a tolerable representation of this nest, and of the caterpillar. The caterpillar is found in June; and the moth ( $\mathrm{No}$ todonta ziczac) from May to July in the following year.-(See cut, p. 172.)

Beside those caterpillars which live solitary in the folds of a leaf, there are others which associate, employing their united powers to draw the leaves of the plants they feed upon into a covering for their common protection. Among these we may mention the caterpillar of a small butterfly, the plantain of Glan

* Roesel. cl. ii., Pap. Nocturn., tab. xx., fig. 1, 2, 3, 4, 5, 6. 
ville fritillary (Melitea cinxia), which is very scarce in this country.

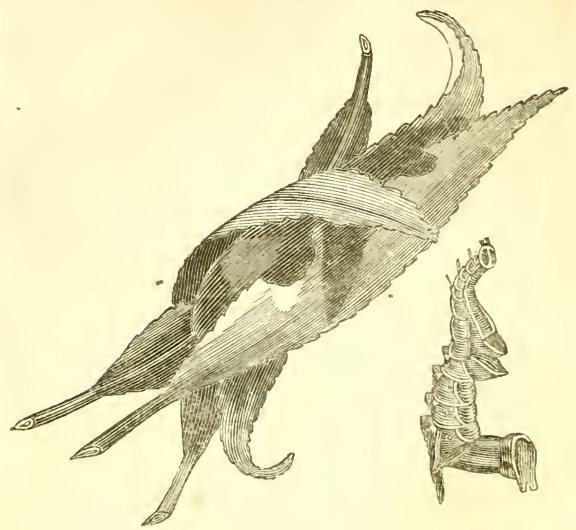

Ziczac Caterpillar and Nest.

Although a colony of these caterpillars is not numerous, seldom amounting to a hundred individuals, the place which they have selected is not hard to discover. Their abode may be seen in the meadow in form of a tutt of herbage covered with a white web, which may readily be mistaken, at first view, for that of a spider, but closer inspection soon corrects this notion. It is, in fact, a sort of common tent, in which the whole brood lives, eats, and undergoes the usual transformations. The shape of this tent, for 
the most part, approaches the pyramidal, though that depends much upon the natural growth of the herbage which composes it. The interior is divided into compartments formed by the union of several small tents, as it were, to which others have been from time to time added according to the necessities of the community.

When they have devoured all the leaves, or at least those which are most tender and succulent, they abandon their first camp, and construct another contiguous to it under a tuft of fresh leaves. Several of these encampments may sometimes be seen within the distance of a foot or two, when they can find plantain (Plantago lanceolata) fit for their purpose; but though they prefer this plant, they content themselves with grass if it is not to be procured.

When they are about to cast their skins, but particularly when they perceive the approach of winter, they construct a more durable apartment in the interior of their principal tent. The ordinary web is thin and semi-transparent, permitting the leaves to be seen through it; but their winter canvass, if we may call it so, is thick, strong, and quite opaque, forming a sort of circular hall without any partition, where the whole community lie coiled up and huddled together.

Early in spring they issue forth in search of fresh food, and again construct tents to protect them from cold and rain, and from the mid-day sun.

M. R aumur found upon trial, that it was not only the caterpillars hatched from the eggs of the same mother which would unite in constructing the common tent ; for different broods, when put together, worked in the same social and harmonious manner. We ourselves ascertained, during the present summer, $(1829$,$) that this principle of sociality is not$ confined to the same species, nor even to the same

VOI. IV. 
genus. The experiment which we tried was to confine two broods of different species to the same branch by placing it in a glass of water to prevent their escape. The caterpillars which we experimented on were several broods of the brown-tail moth (Porthesia auriflua), and the lackey (Clisiocampa neustria). These we found to work with as much industry and harmony in constructing the common tent as if they had been at liberty on their native trees; and when the lackey's encountered the brown-tails they manifested no alarm or uneasiness, but passed over the backs of one another as if they had made only a portion of the branch. In none of their operations did they seem to be subject to any discipline, each individual appearing to work, in perfecting the structure, from individual instinct, in the same manner as was remarked by M. Huber, in the case of the hive-bees.* In making such experiments, it is obvious, that the species of caterpillars experimented with must feed upon the same sort of plant. $\dagger$

The design of the caterpillars in rolling up the leaves is not only to conceal themselves from birds and predatory insects, but also to protect themselves from the cuckoo-flies, which lie in wait in every quarter to deposit their eggs in their bodies, that their progeny may devour them. Their mode of concealment, however, though it appear to be cunningly contrived and skillfully executed, is not always successful, their enemies often discovering their hiding place. We happened to see a remarkable instance of this last summer (1828), in the case of one of the lilac caterpillars which had changed into a chrysalis within the closely folded leaf. I small cuckoo-fly, aware, it should seem, of the very spot where the chrysalis lay within the leaf, was seen boring throngh 
it with her ovipositor, and introducing her eggs through the punctures thus made into the body of the dormant insect. We allowed her to lay all her eggs, about six in number, and then put the leaf under an inverted glass. In a few days the eggs of the cuckoofly were hatched, the grubs devoured the lilac chrysalis, and finally changed into pupæ in a case of yellow silk, and into perfect insects like their parent. ${ }^{*}$

* J. R. 


\section{Chapter IX.}

Insects forming IJabitations of detached Leaves.

The habitations of the insects which we have just described consist of growing leaves, bent, rolled, or pressed together, and fixed in their positions by silken threads. But there are other babitations of a similar kind which are constructed by cutting out and detaching a whole leaf, or a portion of a leaf. We have already seen how dexterously the upholstererbees cut out small parts of leaves and petals with their mandibles, and fit them into their cells. Some of the caterpillars do not exhibit quite so much neatness and elegance as the leaf-cutting bees, though their structures answer all the purposes intended; but there are others, as we shall presently see, that far excel the bees, at least, in the delicate minutiæ of their workmanship. We shall first advert to those structures which are the most simple.

Not far from Longchamps, in a road through the Bois de Boulogne, is a large marsh, which MI. Riaumur never observed to be in a dry state even during summer. This marsh is surrounded with very lofty oaks, and abounds with pondweed, the water plant named by botanists polamogeton. The shining leaves of this plant, which are as large as those of the laurel or orange-tree, but thicker and more fleshy, are spread upon the surface of the water. Having pulled up several of these, about the middle of June, M. Réaumur observed, beneath one of the 
first which he examined, an elevation of an oval shape, which was formed out of a leaf of the same plant. He carefully examined it, and discovered that threads of silk were attached to this elevation. Breaking the threads, he raised up one of the ends, and saw a cavity in which a caterpillar (Hydrocampa Potamogata) was lodged. An indefatigable observer, such as $\mathbf{M}$. $\mathbf{R}$ :aumur, would naturally follow up this discovery; and he has accordingly given us a memoir of the pondweed tent-maker, distinguished by his usual minute accuracy.

In order to make a new cocoon, the caterpillar fastens itself on the underside of a leaf of the Potamogeton. With its mandibles it pierces some part of this leaf, and afterwards gradually gnaws a curve line, marking the form of the piece which it wishes to detach. When the caterpillar has cut off, as from a piece of cloth, a patch of leaf of the size and shape suited to its purpose, it is provided with half of the materials requisite for making a tent. It takes hold of this piece by its mandibles, and conveys it to the situation on the underside of its own, or another leaf, whichever is found most appropriate. It is there disposed, in such a manner, that the underpart of the patch-- the side which was the underpart of the entire leaf - is tumed towards the underpart of the new leaf, so that the inner walls of the cocoon are always made by the underpart of two portions of leaf. The leaves of the potamogeton are a little concave on the underside; and thus the caterpillar produces a hollow cell, though the rims are united.

The caterpillar secures the leaf in its position by threads of white silk. It then weaves a cocoon in the cavity which is somewhat thin, but of very close tissue. There it shuts itself up to appear again only in the form of the perfect insect, and is soon transformed into a chrysalis. In this cocoon of silk no 
point touches the water; whilst the cocoon of leaves, lined with silk, has been constructed underneath the water. This fact proves that the caterpillar has a particular art by which it repels the water from between the leaves.

When a caterpillar, which has thus conveyed, and disposed a patch of leaf against another leaf, is not ready to be transformed into a chrysalis, it applies itself to make a cocoon-a habitation which it may carry everywhere about with it. It begins by slightly fixing the piece against the whole leaf, leaving intervals all round, between the piece and leaf, at which it may project its head. The piece which it has fixed serves as a model for cutting out a similar piece in the other leaf. The caterpillar puts them accurately together, except at one end of the oval, where an opening is left for the insect to project its head through. When the caterpillar is inclined to change its situation, it draws itself forward by means of its scaly limbs rivetted upon the leaf. The membranous limbs which are rivetted against the inner sides of the cocoon, oblige it to follow the anterior part of the body, as it advances. The caterpillar, also, puts its head out of the cocoon every time it desires to eat.

There is found on the common chick-weed (Stellaria media) towards the end of July, a middle-sized smooth green caterpillar, having three brown spots bordered with white on the back, and six legs and ten pro-legs, whose architecture is worthy of observation. When it is about to go into chrysalis, towards the beginning of August, it gnaws off, one by one, a number of the leaves and smaller twigs of the chick-weed, and adjusts them into an oval cocoon, somewhat rough and unfinished, externally, but smooth, uniform, and finely tapestried with white silk within. Here it undergoes its transformations 
securely, and when the period of its pupa trance has expired in the following July, it makes its exit in the form of a yellowish moth, with several brown spots above, and a brown band on each of its four wings below. It is also furnished with a sort of tail.

On the cypress spurge (Euphorbia cyparissias), a native woodland plant, but not of very common occurrence, may be found, towards the end of October, a caterpillar of a middle size, sparely tufted with hair, and striped with black, white, red, and brown. The leaves of the plant which are in the form of short narrow blades of grass, are made choice of by the caterpillar to construct its cocoon, which it does with great neatness and regularity, the end of each leaf, after it has been detached from the plant, being fixed to the stem, and the other leaves placed parallel, as they are successively added. The other ends of all these are bent inwards, so as to form a uniformly rounded oblong figure, somewhat larger at one end than at the other.
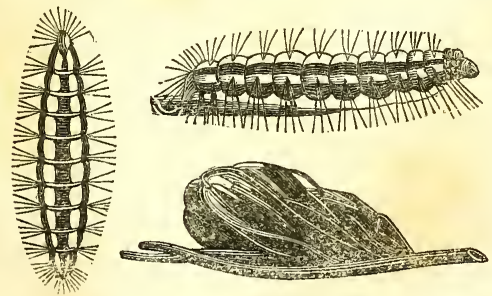

Cypress-Spurge Caterpillar-( Acronycta Euphrasice?)-with a Cocoon, on a branch.

A caterpillar which builds a very similar cocoon to the last mentioned, may be found upon a more common plant-the yellow snap-dragon or toad-flax 
(Antirrhinum linaria) - which is to be seen in alınst every hedge. It is somewhat shaped like a leech, is of a middle size, and the prevailing colour pearl-grey, but striped with yellow and black. It spins up about the beginning of September, forming the outer coating of pieces of detached leaves of the plant, and sometimes of whole leaves placcd longitudinally, the whole disposed with great symmetry and neatness. The moth appears in the following June.

It is worthy of remark, as one of the most striking instances of instinetive foresight, that the caterpillars which build structures of this substantial description, are destined to lie much longer in their chrysalis trance, than those which spin merely a flimsy web of silk. For the most part, indeed, the latter undergo their final transformation in a few weeks; while the former continue entraneed the larger portion of a year, appearing in the perfect state the sunmer after their architectural labours have been completed.* This is a remarkable example of the Instinct which leads these little creatures to act with a foresight in many cases much clearer than the dietates of human prudence. In the examples before us, the instinet is more delicate and complex than that which directs other animals to provide a burrow for their winter sleep. It is not unreasonable to suppose that the one eaterpillar is aware, while it is building the cocoon, that the moth into which it is about to be changed will not be in a fit state to appear before the succeeding summer. The other, pursuing a similar course of thought, may feel that the moth will see the light in a few weeks. The comparative distances of time certainly appear most difficult to be understood by an insect; for, as far as we know; quadrupeds do not carry their intelligence so such extent. And yet in the solitary case of 
provision for a future progeny, the instinct is invariably subtle and extraordinary. What, for instance, is more remarkable than that the insect should always place her eggs where her progeny will find the food which is best suited to their nature? In almost no case does the perfect insect eat that food, so that the parent cannot judge from her own habits. The Contriver of the mechanism by which insects work also directs the instinct by which they use their tools.

It is exceedingly difficult, with our very limited knowledge of the springs of action in the inferior animals, to determine the motives of their industrythat is, whether they see clearly the end and object of their arrangements. A human architect, in all his plans, has regard, according to the extent of his skill, to the combination of beauty and convenience; and in most cases he has adaptations peculiar to the circumstances connected with the purpose of the structure. In the erection of a common dwelling-house, for instance, one family requires many sleepingrooms, another few-one wants its drawing-rooms in a suite, another detached. The architect knows all these wants, and provides for them. But all insects build their habitations upon the same general model, although they can slightly vary them according to circumstances. Thus, according as the uniformity, or the occasional adaptation of their work to particular situations, has been most regarded by those who speculate upon their actions, they have been held to be wholly governed by instinct or by intelligencehave been called machines or free agents. There are difficulties in either conclusion; and the truth perhaps lies between the two opinions. Their actions may entirely result from their organization; they are certainly in conformity with it. Those who would deny the animal all intelligence, by which we mean a power,

VOL. IV. 
yesulting from sclection, of deviating in small matters from a precise rule of action, are often materialists, who shut their eyes to the creating and preserving economy of Providence. But even this belief in the infallible results of organization does not necessarily imply the disbelief of a presiding Power. "The same wisdom," says Bonnet, "which has constructed and arranged with so much art the various organs of animals, and has made them concur towards one determined end, has also provided that the different operations which are the natural results of the economy of the animal should concur towards the same end. The creature is directed towards his object by an invisible hand; he executes with precision, and by one effort, those works which we so much admire; he appears to act as if he reasoned, to return to his labour at the proper time, to change his scheme in case of need. But in all this he only obeys the secret influence which drives him on. He is but an instrument which cannot judge of eacn action, but is wound up by that adorable Intelligence, which has traced out for every insect its proper labours, as he has traced the orbit of each planet. When, therefore, I see an insect working at the construction of a nest, or a cocoon, I am impressed with respect, because it seems to me that I am at a spectacle where the Supreme Artist is hid behind the curtain." "*

There is a small sort of caterpillar which may be found on old walls, feeding upon minute mosses and lichens, the proceedings of which are well worthy of attention. They are similar, in appearance and size, to the caterpillar of the small cabbage-butterfly (Pontia rapae), and are smooth and bluish. The material which they use in building their cocoons is

* Contemplation de la Nature, part xr. chap. 38 . 
composed of the leaves and branchlets of green moss, which they cut into suitable pieces, detaching at the same time along with them a portion of the earth in which they grow. They arrange these upon the walls of their building with the moss on the outside, and the earth on the inside, making 'a sort of vault of the tiny bits of green moss turf, dug from the surface of the wall. So neatly, also, are the several pieces joined, that the whole might well be supposed to be a patch of moss which had grown in form of an oval tuft, a little more elevated than the rest growing on the wall. When these caterpillars are shut up in a box with some moss, without earth, they construct with it cells in form of a hollow ball, very prettily plaited and interwoven.

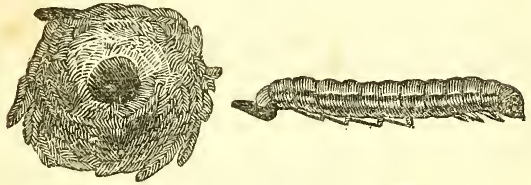

MIoss-Cell of Small Caterpillar (Bryophila perla.)

In May last (1829), we found on the walls of Greenwich Park, a great number of caterpillars whose manners bore some resemblance to those of the grub described by MI. Réaumur.* They were of middle size, with a dull orange stripe along the back; the head and sides of the body black, and the belly greenish. Their abodes were constructed with ingenuity and care. A caterpillar of this sort appears to choose either a part where the mortar contains a cavity, or it digs one suited to its design. Orer the opening of the hollow in the mortar, it 
builds an arched wall so as to form a chamber considerably larger than is usual with other architect caterpillars. It selects grains of mortar, brick, or lichen, fixing them, by means of silk, firmly into the structure. As some of these vaulted walls were from an inch to an inch and a half long, and about a third of an inch wide and deep, it may be well imagined that it would require no little industry and labour to complete the work. Yet it does not demand more than a few hours for the insect to raise it from the foundation. Like all other insect architects, this caterpillar uses its own body for a measuring rule, and partly for a mould, or rather a block or centre to shape the walls by, curving itself round and round concentrically with the arch which it is building.

We afterwards found one of these caterpillars which had dug a cell in one of the softest of the bricks, covering itself on the outside with an arched wall of brick dust, cemented with silk. As this brick was of a bright red colour, we were thereby able to ascertain that there was not a particle of lichen employed in the structure.

The neatness mentioned by Reaumur, as remarkable in his moss-building caterpillars, is equally observable in that which we have just described; for, on looking at the surface of the wall, it would be impossible for a person unacquainted with these structures to detect where they were placed, as they are usually, on the outside, level with the adjoining brick-work, and it is only when they are opened by the entomologist, that the little architect is perceived lying snug in his chamber. If a portion of the wall be thus broken down, the caterpillar loses no time in repairing the breach, by piecing in bits of mortar and fragments of lichen, till we can scarcely -distinguish the new portion from the old. 


\section{Chapter $\mathbf{X}$.}

Caddis-Worms and Carpenter-Carterpillar.

There is a very interesting class of grubs which live under water, where they construct for themselves moveable tents of various materials as their habits direct them, or as the substances they require can be conveniently procured. Among the materials used by these singular grubs, well known to fishermen by the name of caddis-vorms, and to naturalists as the larva of the four-winged flies in the order Trichoptera, we may mention sand, stones, shells, wood, and leaves, which are skilfully joined and strongly cemented. One of these grubs forms a pretty case of leaves glued together longitudinally, but leaving an aperture sufficiently large for the inhabitant to put out its head and shoulders when it wishes to look about for

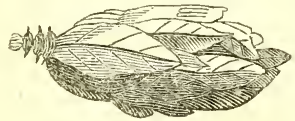

Leaf nest of Cuddis Worms.

food. Another employs pieces of reed cut into con venient lengths, or of grass, straw, wood, \&c., carefully joining and cementing each piece to its fellow as the work proceeds; and he frequently finishes the

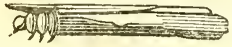

Reed Nest of Caddis-Worm.

ror. IV. 
whole by adding a broad piece longer than the rest in shade his door-way over-head, so that he may not be seen from above. A more laborious structure is reared by the grub of a beautiful caddis-fly (Phryganea), which weaves together a group of the leaves of aquatic plants into a roundish ball, and in the interior of this forms a cell for its abode. The following figure from Roesel will give a more precise notion of this structure than a lengthened description.

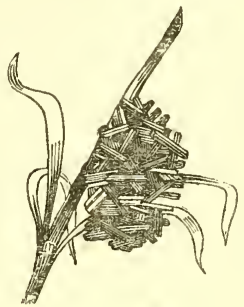

Another of these aquatic architects malie choice of the tiny shells of young fresh-water mussels and snails (Planorbis), to form a moveable grotto, and as these little shells are for the most part inhabited, he keeps the poor animals close prisoners, and drags

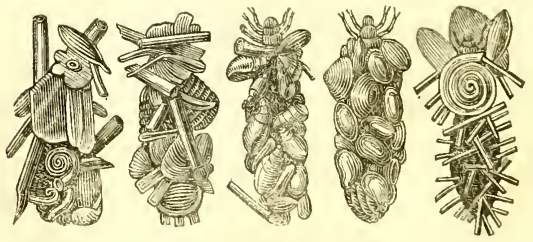

Shell Nests of Caddis-Worms. 
them without mercy along with him. These grottobuilding grubs are by no means uncommon in ponds; and in chalk districts, such as the country about Woolwich and Gravesend, they are very abundant.

One of the most surprising instances of their skill occurs in the structures of which small stones are the principal material. The problem is to make a tube about the width of the hollow of a wheat straw or a crow quill, and equally smooth and uniform. Now the materials being small stones full of angles and irregularities, the difficulty of performing this problem will appear to be considerable, if not insurmountable; yet the little architects, by patiently examining their stones and turning them round on every side, never fail to accomplish their plans. This, however, is only part of the pro-

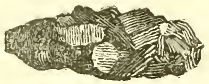

Slone Nest of Caddis-Worm.

blem, which is complicated with another condition, and which we have not found recorded by former observers, namely, that the under surface shall be flat and smooth, without any projecting angles which might impede its progress when dragged along the bottom of the rivulet where it resides. The selection of the stones, indeed, may be accounted for, from this species living in streams where, but for the weight of its house, it would to a certainty be swept away. For this purpose, it is probable that the grub makes choise of larger stones than it might otherwise want; and therefore also it is that we frequently find a case composed of very small stones and sand, to which,

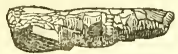

Sand Nest balanced wilh a Stone. 
when nearly finished, a large stone is added by way of ballast. In other instances, when the materials are found to possess too great specific gravity, a bit of light wood, or a hollow straw, is added to buoy up the case.

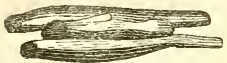

Nest of Caddis-worm balanced with Strows.

It is worthy of remark, that the cement, used in all these cases, is superior to pozzolana* in standing water, in which it is indissoluble. The grubs themselves are also admirably adapted for their mode of life, the portion of their bodies which is always enclosed in the case, being soft like a meal-worm, or garden caterpillar, while the head and shoulders, which are for the most part projected beyond the door-way in search of food, are firm, hard, and consequently less liable to injury than the protected portion, should it chance to be exposed.

We have repeatedly tried experiments with the inhabitants of those aquatic tents, to ascertain their mode of building. We have deprived them of their little houses, and furnished them with materials for constructing new ones, watching their proceedings from their laying the first stone or shell of the structure. They work at the commencement in a very clumsy manner, attaching a great number of chips to whatever materials may be within their reach with loose threads of silk, and many of these they never use at all in their perfect building. They act, indeed, much like anunskilful workman trying his hand before committing himself upon an intended work of difficult execution. Their main intention is, however, to have abundance of materials within reach: for after their dwelling is fairly begun, they shut them-

* A cement prepared of volcanic earth, or lava. 
selves up in it, and do not again protrude more than half of their body to procure materials; and even when they have dragged a stone, a shell, or a chip of reed within building reach, they have often to reject it as unfit.*

\section{Carpenter-Caterpillars.}

Insects, though sometimes actuated by an instinct apparently blind, unintelligent, or unknown to themselves, manifest in other instances a remarkable adaptation of means to ends. We have it in our power to exemplify this in a striking manner by the proceedings of the caterpillar of a goat-moth (Cossus ligniperda) which we kept till it underwent its final change.

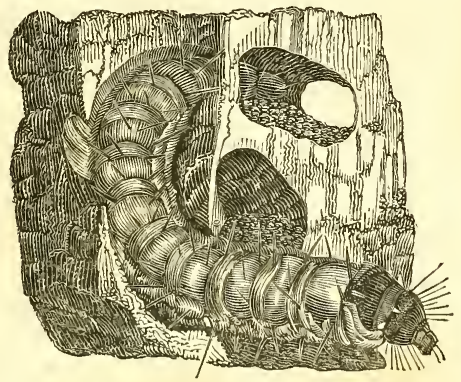

Caterpillar of Goat-Moth in a Willow Tree.

This caterpillar, which abounds in Kent and many other parts of the island, feeds on the wood of willows, oaks, poplars, and other trees, in which it eats extensive galleries; but it is not contented with the protection afforded by these galleries during

* J, R, 
the colder months of winter, before the arrival of which it scoops out a hollow in the tree, if it do not find one ready prepared, sufficiently large to contain its body in a bent or somewhat coiled up position. On sawing off a portion of an old poplar in the winter of 1827 , we found such a cell with a caterpillar coiled up in it.

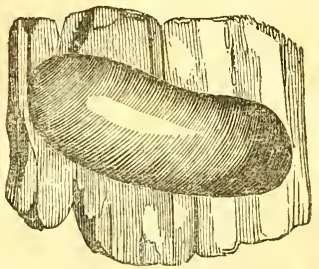

Winter Nest of the Goat Caterpillar.

It had not, however, been contented with the bare walls of the retreat which it had hewn out of the tree, for it had lined it with a fabric as thick as coarse broad-cloth, and equally warm, composed of the raspings of the wood scooped out of the cell, united with the strong silk which every species of caterpillar can spin. In this snug retreat our caterpillar, if it had not been disturbed, would have spent the winter without eating; but upon being removed into a warm room and placed under a glass along with some pieces of wood which it might eat if so inclined, it was roused for a time from its dormant state, and began to move about. It was not long, however, in constructing a new cell for itself, no less ingenious than the former. It either could not gnaw into the fir plank, where it was now placed with a glass above it, or it did not choose to do so; for it left it untouched, and made it the basis of the edifice it began to construct. It 
formed, in fact, a covering for itself precisely like the one from which we had dislodged it,-composed of raspings of wood detached for the purpose from what had been given it as food,- the largest piece of which was employed as a substantial covering and protection for the whole. It remained in this retreat, motionless, and without food, till revived by the warmth of the ensuing spring, when it gnawed its way out, and began to eat voraciously, to make up for its long fast.

These caterpillars are three years in arriving at their final change into the winged state; but as the one just mentioned was nearly full grown, it began, in the month of May, to prepare a cell, in which it might undergo its metamorphosis. Whether it had actually improved its skill in architecture by its previous experience we will not undertake to say, but its second cell was greatly superior to the first. In the first there was only one large piece of wood employed; in the second, two pieces werc placed in such a manner as to support each other, and beneath the angle thus formed, an oblong structure was made, composed, as before, of wood-raspings and silk, but much stronger in texture than the winter cell. In a few weeks (four, if we recollect right) the moth came forth.*

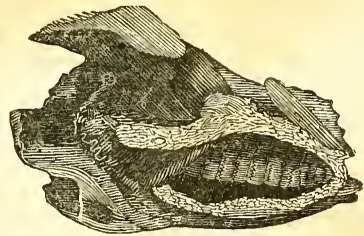

Nest of Goat-Moth.-Figured from specimen, and raised to show the $P u p a$. 
A wood-boring caterpillar, of a species of moth much rarer than the preceding (JEgeria asiliformis, Stephens), exhibits great ingenuity in constructing a cell for its metamorphosis. We observed above a dozen of them during this summer (1829) in the trunk of a poplar, one side of which had been stripped of its bark. It was this portion of the trunk which all the caterpllars selected for their final retreat, not one having been observed where the tree was covered with bark. The ingenuity of the little architect consisted in scooping its cell almost to the very surface of the wood, leaving only an exterior covering of unbroken wood, as thin as writing paper. Previous, therefore, to the chrysalis making its way through this feeble barrier, it could not have been suspected that an insect was lodged under the smooth wood. We observed more than one of these in the act of breaking through this covering, within which there is besides a round moveable lid of a sort of brown wax.*

Another architect caterpillar, frequently to be met with in July on the leaves of the willow and the poplar, is, in the fly state, called the Puss-Moth (Cerura vinula). The caterpillar is produced from brown-coloured shining eggs, about the size of a pin's head, which are deposited-one, two, or more together-on the upper surface of a leaf. In the course of six or eight weeks (during which time it casts its skin thrice) it arrives at its full

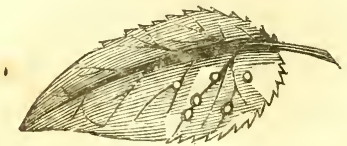

Eggs of the Puss-Moth.

* J. R. 
growth, when it is about as thick, and nearly as long, as a man's thumb, and begins to prepare a structure in which the pupa may sleep securely during the winter. As we have, oftener than once, seen this little architect at work, from the foundation till the completion of its edifice, we are thereby enabled to give the details of the process.

The puss, it may be remarked, does not depend for protection on the hole of a tree, or the shelter of an overhanging branch, but upon the solidity and strength of the fabric which it rears. The material it commonly uses is the bark of the tree upon which the cell is constructed; but when this cannot be procured, it is contented to employ whatever analogous materials may be within reach. One which we had shut up in a box substituted the marble paper it was lined with, for bark, which it could not procure.* With silk it first wove a thin web round the

* It is justly remarked by $\mathbf{R}$ aumur, that when caterpillars are left at liberty among their native plants, it is only by lucky chance they can be observed building their cocoons, because the greater number abandon the plants upon which they have been feeding, to spin up in places at some distance. In order to see their operations they must be kept in confinement, particularly in boxes, with glazed doors, where they may be always under the eye of the naturalist. In such circumstances, however, we may be ignorant what building materials we ought to provide them with for their structures. A red caterpillar, with a few tufts of hair, which R aumur found in July feeding upon the flower bunches of the nettle, and refusing to touch the leaves, began in a few days to prepare its cocoon, by gnawing the paper lid of the box in which it was placed. This, of course, was a material which it could not have procured in the fields, but it was the nearest in properties that it could procure; for though it had the leaves and stems of nettles, it never used a single fragment of either. When R. aumur found that it was likely to gnaw through the paper lid of the box, and might effect its escape, he furnished it with bits of rumpled paper, fixed, to the lid by means of a pin; and these it chopped down into such pieces as it judged convenient for its structure, which it took

VOL IV. 
edges of the place which it marked out for its edifice; then it ran several threads in a sparse manner from side to side, and from end to end, but very irregularly in point of arrangement: these were intended for the skeleton or frame-work of the building.

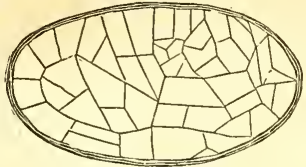

Rudiments of the Cell of the Puss-Moth.

When the outline was finished, the next step was to strengthen each thread of silk, by adding several (sometimes six or eight) parallel ones, all of which were then glued together into a single thread, by the insect running its mandibles, charged with gluten, along the line. The meshes, or spaces, which were thus widened by the compression of the parallel threads, were immediately filled up with fresh threads, till at length only very small spaces were left. It was in this stage of the operation that the paper came into requisition, small portions of it being gnawed off the box and glued into the meshes. It was not, however, into the meshes only that the bits of paper were inserted; for the whole fabric was in the end thickly studded over with them. In about half a day from the first thread of the frame-work being spun the building was completed. It was at first, however, rather soft, and yielded to slight pressure with the finger; but as soon as it became

day to complete. The moth appeared four weeks after, of a brownish-black colour, mottled with white, or rather grey, in the manner of lace.

Bonnet also mentions more than one instance in which hc observed caterpillars making use of paper, when they could not procure other materials. 
thoroughly dry, it was so hard that it could with difficulty be penetrated with the point of a penknife.*

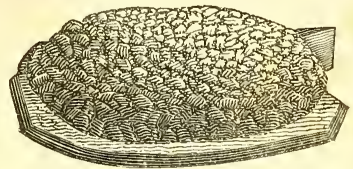

Cell built by the Lar'va of the Puss-Moth.

A question will here suggest itself to the curious inquirer, how the moth, which is not, like the caterpillar, furnished with mandibles for gnawing, can find its way through so hard a wall. To resolve this question, it is asserted by recent naturalists (see Kirby and Spence, vol. iii. p. 15), that the moth is furnished with a peculiar acid for dissolving itself a passage. We have a specimen of the case of a puss-moth, in which, notwithstanding its strength, one of the ichneumons had contrived to deposit its eggs. In the beginning of summer, when we expected the moth to appear, and felt anxious to observe the recorded effects of the acid, we were astonished to find a large orange cuckoo-fly make its escape; while another, which attempted to follow, stuck by the way and died. On detaching the cell from the box, we found several others, which had not been able to get out, and had died in their cocoons. $\dagger$

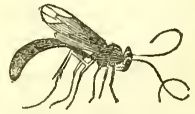

Ichneumon (Ophion luteum) figured from the one mentioned.
* J. R.
+ J. R. 
Among the carpenter-grubs may be mentioned that of the purple capricorn-beetle (Callidium violaceum,) of which the Rev $\operatorname{Mr}$ Kirby has given an interesting account in the fifth volume of the Linnean Transactions. This insect feeds principally on fir timber, which has been felled some time without having had the bark stripped off; but it is often found on other wood. Though occasionally taken in this kingdom, it is supposed not to have been originally a native. The circumstance of this destructive little animal attacking only such timber as had not been stripped of its bark ought to be attended to by all persons who have any concern in this article; for the bark is a temptation not only to this, but to various other insects; and much of the injury done in timber might be prevented, if the trees were all barked as soon as they were felled. The female is furnished, at the posterior extremity of her body, with a flat retractile tube, which she inserts between the bark and the wood, to the depth of about a quarter of an inch, and there deposits a single egg. By stripping off the bark, it is easy to to trace the whole progress of the grub, from the spot where it is hatched, to that where it attains its full size. It first proceeds in a serpentine direction, filling the space which it leaves with its excrement, resembling saw-dust, and so stopping all ingress to enemies from without. When it has arrived at its utmost dimensions, it does not confine itself to one direction, but works in a kind of labyrinth, eating backwards and forwards, which gives the wood under the bark a very irregular surface; by this means its paths are rendered of considerable width. The bed of its paths exhibits, when closely examined, a curious appearance, occasioned by the gnawings of its jaws, which excavate an infinity of little ramified canals. When the insect is about to assume its chrysalis statc, it bores down obliquely 
into the solid wood, to the depth sometimes of three inches, and seldom if ever less than two, forming holes nearly semi-cylindrical, and of exactly the form of the grub which inhabits them. At first sight one would wonder how so small and seemingly só weak an animal could have strength to excavate so deep a mine; but when we examine its jaws our wonder ceases. These are large, thick, and solid sections of a cone divided longitudinally, which, in the act of chewing, apply to each other the whole of their interior plane surface, so that they grind the insect's food like a pair of millstones. Some of the grubs are hatched in October; and it is supposed that about the beginning of March they assume their chrysalis state. At the place in the bark, opposite to the hole from whence they descended into the wood, the perfect insects gnaw their way out, which generally takes place betwixt the middle of May and the middle of June. These insects are supposed to fly only in the night, but during the day they may generally be found resting on the wood from which they were disclosed. The grubs are destitute of feet, pale, folded, somewhat hairy, convex above, and divided into thirteen segments. Their head is large and convex.*

It would not be easy to find a more striking example of ingenuity than occurs in a small caterpillar which may be found in May, on the oak, and is supposed, by Kirby and Spence, to be that of the Pyralis strigulalis. It is of a whitish yellow colour, tinged with a shade of carnation, and studded with tufts of red hairs, on each segment, and two brown spots behind the head. It has fourteen feet, and the upper part of its body is much flatter than is common in caterpillars. When this ingenious little insect begins to form its cell, it selects a smooth young branch

* Kirby in Linn. Trans. vol. v. p. 246, and Introd. ii.

rOL. IV. 
of the oak, near an offgoing of the branchlets whose angle may afford it some protection. It then measures out, with its body for a rule, the space destined for its structure, the basement of which is of a triangular form, with the apex at the lower end. The building itself is composed of small rectangular strap-shaped pieces of the outer bark of the branch cut out from the immediate vicinity; the insect indeed never travels farther for materials than the length of its own body. Upon the two longest sides of the triangular base it builds uniform walls, also of a triangular shape, and both gradually diverging from each other as they increase in height. These are formed with so much mathematical precision, that they fit exactly when they are afterwards brought into contact. As soon as the little architect has completed these walls, which resemble very much the feathers of an arrow,
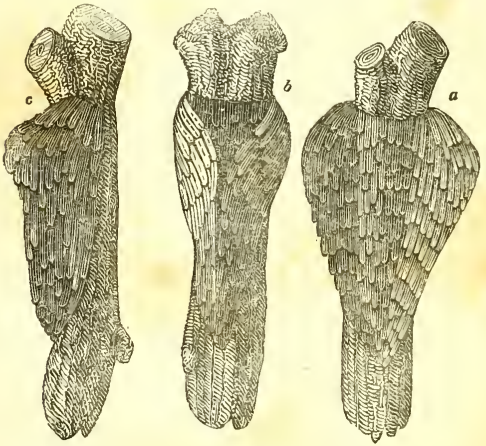

Magnified Cells of Pyralis Strigulalis ?

$a$ The walls before they are joined. $b$. Walls joined, but not closed a, top. c. Side view of structure complete. 
it proceeds to draw them together in a manner similar to that which the leaf-rolling caterpillars employ in constructing their abodes, by pulling them with silken cords till they bend and converge. Even when the two longest sides are thus joined, there is an opening left at the upper end, which is united in a similar manner. When the whole is finished, it requires close inspection to distinguish it from the branch, being formed of the same materials, and having consequently the same colour and gloss. Concealment, indeed, may be supposed, with some justice, to be the final object of the insect in producing this appearance, the same principle being extensively exemplified in numerous other instances. 


\section{Chapter Xi.}

\section{Earth-Mason Caterpillars.}

Many species of caterpillars are not only skilful in concealing themselves in their cocoons, but also in the concealment of the cocoon itself; so that even when that is large, as in the instance of the death's-head hawk-moth (Acherontia alropos), it is almost impossible to find it. We allude to the numerous class of caterpillars which, previous to their changing into the pupa state, bury themselves in the earth. This circumstance would not be surprising, were it confined to those which are but too well known in gardens, from their feeding upon and destroying the roots of lettuce, chicory, and other plants, as they pass a considerable portion of their lives under ground; nor is it surprising that those which retire under ground during the day, and come abroad to feed in the night, should form their cocoons where they have been in the habit of concealing themselves. But it is very singular and unexpected, that caterpillars, which pass the whole of their life on plants, and even on trees, should afterwards bury themselves in the earth. Yet, the fact is, that perhaps a greater number make their cocoons under than above ground, particularly those which are not clothed with hair.

Some of those caterpillars, which go into the ground previous to their change, make no cocoon at all, but are contented with a rude masonry of earth as a nest for their pupæ: into the details of their operations it will not be so necessary for us to go, as into those which exhibit more ingenuity 
and care. When one of the latter is dug up, it has the appearance of nothing more than a small clod of earth, of a roundish or oblong shape, but, generally, by no means uniform. The interior, however, when it is laid open, always exhibits a cavity, smooth, polished, and regular, in which the cocoon, or the chrysalis lies secure. (Fig. p. 202, B). The polish of the interior is precisely such as might be given to soft earth by moistening and kneading it with great care. But beside this, it is usually lined with a tapestry of silk, more or less thick, though this cannot always be discovered without the aid of a magnifying glass. This species of caterpillars, as soon as they have completed their growth, go into the earth, scoop out, as the cossus does in wood, a hollow cell of an oblong form, and line it with pellets of earth, from the size of a grain of sand to that of a pea-united, by silk or gluten, into a fabric more or less compact, according to the species, but all of them fitted for protecting the inhabitant, during its winter sleep, against cold and moisture.
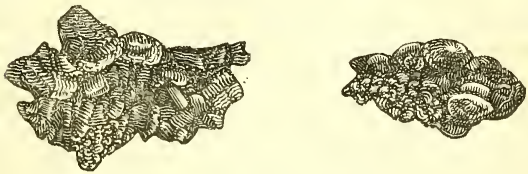

Outside V'iew of Nests of Earth.mason Caterpillars.

One of the examples of this occurs in the ghostmoth (Hepialus humuli), which, before it retires into the earth, feeds upon the roots of the hop or the burdock. Like other insects which construct cells under ground, it lines the cemented earthern walls of its cell with a smooth tapestry of silk, as closely woven as the web of the house-spider.

Inaccurate observers have inferred that these 


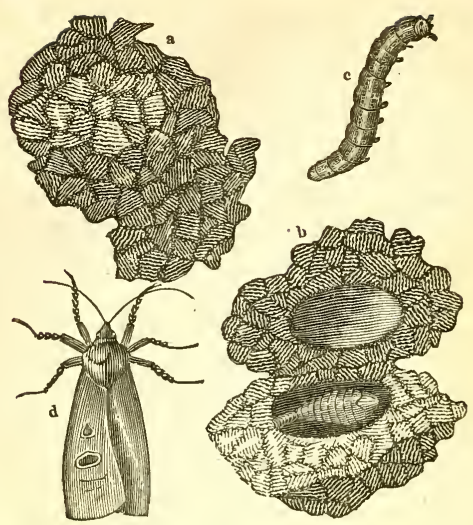

Nests, $6 c$, of an Earth-mason Caterpillar.

earthern structures were formed by a very rude and unskilful process - the caterpillar, according to them, doing nothing more than roll itself round, while the mould adhered to the gluey perspiration with which they describe its body to be covered. This is a process as far from the truth, as Aristotle's account of the spider spinning its web from wool taken from its body. Did the caterpillar do nothing more than roll itself in the earth, the cavity would be a long tube fitted exactly to its body (fig. c): it is essentially different.

It does not indeed require very minute observation to perceive, that every grain of earth in the structure is united to the contiguous grains by threads of silk; and that consequently, instead of the whole having been done at once, it must have required rery considerable 
time and labour. This construction is rendered more obvious by throwing one of these earthen cases into water, which dissolves the earth, but does not act on the silk which binds it together. 'To understand how this is performed, it may be not unin. teresting to follow the little mason from the beginning of his task.

When one of those burrowing caterpillars has done feeding, it enters the earth, to the depth of several inches, till it finds mould fit for its purpose. Having nowhere to throw the earth which it may dig out, the only means in its power of forming a cavity is to press it with its body; and, by turning round and round for this purpose, an oblong hollow is soon made. But were it left in this state, as R'́aumur well remarks, though the vault might endure the requisite time by the viscosity of the earth alone, were no change to take place in its humidity, yet, as a great number are wanted to hold out for six, eight, and ten months, they require to be substantially built; a mere lining of silk, therefore, would not be sufficient, and it becomes necessary to have the walls bound with silk to some thickness.

When a caterpillar cannot find earth sufficiently moist to bear kneading into the requisite consistence, it has the means of moistening it with a fluid which it ejects for the purpose; and as soon as it has thus prepared a small pellet of earth, it fits it into the wall of the vault, and secures it with silk. As the little mason, however, always works on the inside of the building, it does not, at first view, appear in what manner it can procure materials for making one or two additional walls on the inside of the one first built. As the process takes place under ground, it is not easy to discover the particulars, for the caterpillars will not work in glazed boxes. The difficulty was completely overcome by M. R caumur, in the instance 
of the caterpillar of the water-betony moth ( $\mathrm{Cu}$ cullia scrophularice, SchraUk), which he permitted to construct the greater part of its underground building, and then dug it up and broke a portion off from the end, leaving about a third part of the whole to be rebuilt. Those who are unacquainted with the instincts of insects might have supposed that, being disturbed by the demolition of its walls, it would have left off work; but the stimulus of providing for the great change is so powerful, that scarcely any disturbance will interrupt a caterpillar in this species of labour.

The little builder accordingly was not long in recommencing its task for the purpose of repairing the disorder, which it accomplished in about four hours. At first it protruded its body almost entirely beyond the breach which had been made, to reconnoitre the exterior for building materials. Earth was put within its reach, of the same kind as it had previously used, and it was not long in selecting a grain adapted to its purpose, which it fitted into the wall and secured with silk. It first enlarged the outside of the wall by the larger and coarser grains, and then selected finer for the interior. But before it closed the aperture, it collected a quantity of earth on the inside, wove a pretty thick network tapestry of silk over the part which remained open, and into the meshes of this, by pushing and pressing, it thrust grains of earth, securing them with silk till the whole was rendered opaque; and the further operations of the insect could no longer be watched, except that it was observed to keep in motion, finishing, no doubt, the silken tapestry of the interior of its little chamber. When it was completed M. Reaumur ascertained that the portion of the structure which had been built under his eye was equally thick and compact with the other, which had been done under ground. 

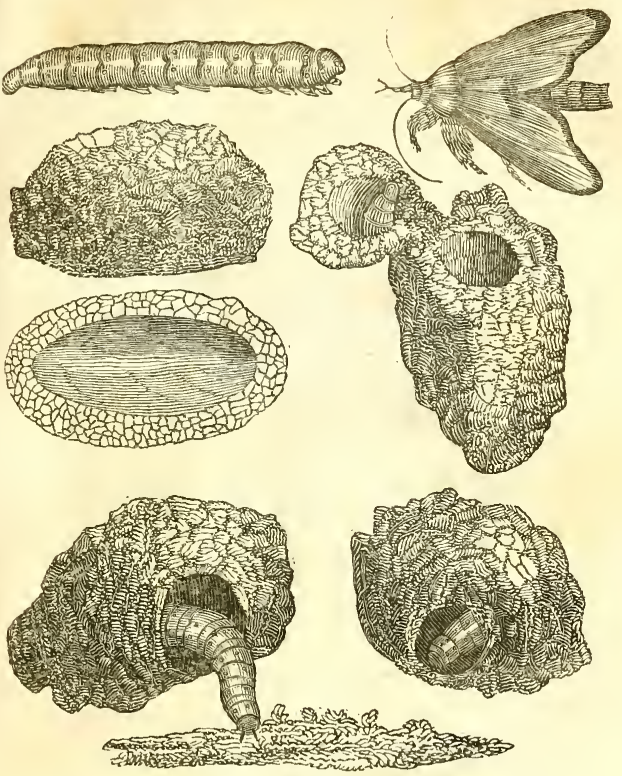

Earth-Mason Caterpillar's $N_{e s t s}$ with the perfect Moth, \&c.

The grubs of several of the numerous species of may-fly (Ephemera) excavate burrows for themselves in soft earch, on the banks of rivers and canais, under

vol. IV 
the level of the water, an operation well described by Scopoli, Swammerdam, and Réaumur. The excavations are always proportioned to the size of the inhabitant; and consequently, when it is young and small, the hole is proportionally small, though, with respect to extent, it is always at least double the length of its body. The hole, being under the level of the river, is always filled with water, so that the grub swims in its native element, and while it is secure from being preyed upon by fishẻs, it has its own food within easy reach. It feeds, in fact, if we may judge from its egesta, upon the slime or moistened clay with which its hole is lined.
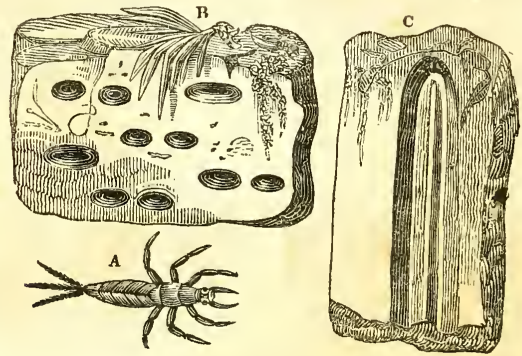

Nests of the Grubs of Ephemera.

A. The grub. B. Perforations in a river bank. C. One laid open to show the parallel structure.

In the bank of the stream at Lee in Kent, we had occasion to take up an old willow stump, which, previous to its being driven into the bank, had been perforated in numerous places by the caterpillar of the 
goat-moth (Cossus ligniperda). From having been driven amongst the moist clay, these perforations became filled with it, and the grubs of the ephemeræ found them very suitable for their habitation; for the wood supplied a more secure protection than if their galleries had been excavated in the clay. In these holes of the wood we found several empty, and some in which were full grom $\mathrm{n}$ grubs.**

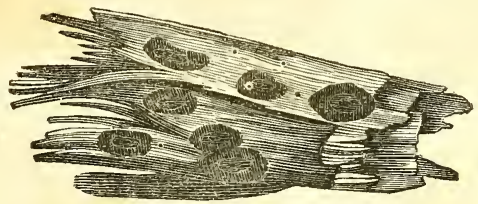

Nests of Ephemera in holes of Cossus.

The architecture of the grub of a pretty genus of beetles, known to entomologists by the name of $\mathrm{Ci}$ cirdela, is peculiarly interesting. It was first made known by the eminent French naturalists, Geoffroy, Desmarest, and Latreille. This grub, which may be met with during spring, and also in summer and autumn, in sandy places, is long, cylindric, soft, whitish, and furnished with six brown scaly feet. The head is of a square form, with six or eight eyes, and very large in proportion to the body. They have strong jaws, and on the eighth joint of the body there are two fleshy tubercles, thickly clothed with reddish hairs, and armed with a recurved horny spine, the whole giving to the grub the form of the letter $Z$.

With their jaws and feet they dig into the carth to the depth of eighteen inches, forming a cylindrical cavity of greater diameter than their body, and furnished with a perpendicular entrance. In construct- 
ing this, the grub first clears away the particles of earth and sand by placing them on its broad trapezoidal head, and carrying the load in this manner beyond the area of the excavation. When it gets deeper down, it climbs gradually up to the surface with similar loads by means of the tubercles on its back, above described. This process is a work of considerable time and difficulty, and in carrying its loads, the insect has often to rest by the way to recover strength for a renewed exertion. Not unfrequently, it finds the soil so ill adapted to its operations, that it abandons the task altogether, and begins anew in another situation. When it has succeeded in forming a complete den, it fixes itself at the entrance by the hooks of its tubercles, which are admirably adapted for the purpose, forming a fulcrum or support, while the broad plate on the top of the head exactly fits the aperture of the excavation, and is on a level with the soil. In this position, the grub remains immoveable, with jaws expanded, and ready to seize and devour every insect which may wander within its reach, particularly the smaller beetles; and its voracity is so great, that.it does not spare even its own species. It precipitates its prey into the excavation, and in case of danger, it retires to the bottom of its den, a circumstance which renders it not a little difficult to discover the grub. The method adopted by the French naturalists was to introduce a straw or pliant twig into the hole, while they dug away, by degrees and with great care, the earth around it, and usually found the grub at the bottom of the cell, resting in a zigzag position like one of the caterpillars of the geometric moths.

When it is about to undergo its transformation into a pupa, it carefully closes the mouth of the den, and retires to the bottom in security.

It does not appear that the grub of the genus 
Cicindela uses the excavation just described for the purpose of a trap or pitfall, any further than that it can more effectually secure its prey by tumbling them down into it; but there are other species of grubs which construct pitfalls for the express purpose of traps. Among these is the larva of a fly (Rhagio vermileo), not unlike the common flesh maggot. The den which it constructs is in the form of a funnel, the sides of which are composed of sand or loose earth. It forms this pitfall of considerable depth, by throwing out the earth obliquely on all sides; and when its trap is finished, it stretches itself along the bottom, remaining stiff and motionless, like a piece of wood. The last segment of the body is bent at an angle with the rest, so as to form a strong point of support in the struggles which it must often have to encounter with vigorous prey. The instant that an insect tumbles into the pitfall, the grub pounces upon it, wreathes itself round it like a serpent, transfixes it with its jaws, and sucks its juices at its ease. Should the prey by any chance escape, the grub hurls after it jets of sand and earth, with astonishing rapidity and force, and not unfrequently succeeds in again precipitating it to the bottom of its trap.

\section{The Avt-Lion.}

The observations of the continental naturalists have made known to us a pitfall constructed by an insect, the details of whose operations are exceedingly curious-we refer to the grub of the ant-lion (Myrmeleon formicarius), which, though marked by Dr Turton and Mr Stewart as British, has not (at least of late years) been found in this country. As it is not, however, uncommon in France and Switvol. IV. 
zerland, it is probable it may yet be discovered in some spot hitherto unexplored, and if so, it will weil reward the research of the curious.

The ant-lion grub being of a grey colour, and having its body composed of rings, is not unlike a woodlouse (Oniscus), though it is larger, more triangular, has only six legs, and most formidable jaws, in form of a reaping-hook, or a pait of calliper compasses. These jaws, however, are not for masticating, but are perforated and tubular, for the purpose of sucking the juices of ants upon which it feeds. Vallisnieri was, therefore, mistaken, as Ríaumur well remarks, when he supposed that he had discovered its mouth. Its habits require that it should walk backwards, and this is the only species of locomotion which it can perform. Even this sort of motion it executes very slowly; and were it not for the ingenuity of its stratagems, it would fare but sparingly, since its chief food consists of ants, whose activity and swiftness of foot would otherwise render it impossible for it to make a single capture. Nature, howrever, in this, as in nearly every other case, lias given a compensating power to the individual animal, to balance its privations. The ant-lion is slow-but it is extremely sagacious;-it cannot follow its prey, but it can entrap it.

The snare which the grub of the ant-lion employs consists of a funnel-shaped excavation formed in loose sand, at the bottom of which it lies in wait for the ants that chance to stumble over the margin, and cannot, from the looseness of the walls, gain a sufficient footing to effect their escape. When the pitfall is intended to be small, it only thrusts its body backwards into the sand as far as it can, throwing out at intervals the particles which fall in upon it, till it is rendered of the requisite depth.

By shutting up one of these grubs in a box with 

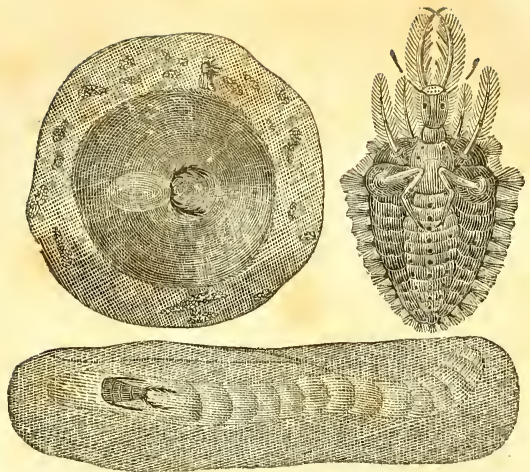

Givb of the Aint-Lion snagrificd, anith one profect Tiup, and enotiter begun.

loose sand, it has been repeatedly observed corstructing its trap of various dimensions, from one to three inches in diameter, according to circumstances. When it intends to make one of considerable diame ter, it proceeds as methodically as the most skilful architect or engineer amongst ourselves. It first examines the nature of the soil, whether it be sufficiently dry and fine for its purpose, and if so, it begins by tracing out a circle, where the mouth of its funnel-trap is intended to be. Having thus marked the limits of its pit, it proceeds to scoop out the interior. Getting within the circle, and using one of its legs as a shovel, it places therewith a load of sand on the flat part of its head, and it throws the whole with a jerk some inches beyond the circle. It is worthy of remark that it only uses. 
one leg in this operation-the one, namely, which is nearest the centre of the circle. Were it to employ the others in digging away the sand, it would encroach upon the regularity of its plan. Working with great industry and adroitness in the manner we have just described, it quickly makes the round of its circle, and as its works backwards it soon arrives at the point where it had commenced. Instead, however, of proceeding from this point in the same direction as before, it wheels about and works a round in the contrary direction, and in this way it avoids throwing all the fatigue of the labour on one leg, alternating them every round of the circle.

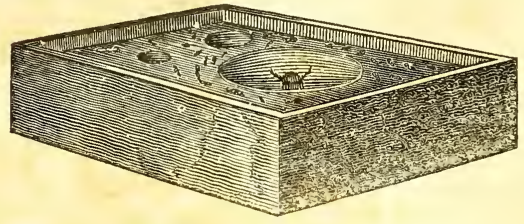

Ant-Lion's Pitfa'ls, in an experinenting-box.

Were there nothing to scoop out but sand or loose earth, the little engineer would have only to repeat the operations we have described, till it had completed the whole. But it frequently happens in the course of its labours, sometimes even when they are near a close, that it will meet with a stone of some size which would, if suffered to remain, injure materially the perfection of its trap. But such obstacles as this do not prevent the insect from proceeding: on the contrary, it redoubles its assiduity to remove the obstruction, as M. Bonnet repeatedly witnessed. If the stone be smal, it can manage to jerk it out in the same manner as the sand; but when it is two or 
three times larger and heavier than its own body, it must have recourse to other means of removal. The larger stones it usually leaves till the last, and when it has removed all the sand whicn it intends, it then proceeds to try what it can do with the less manageable obstacles. For this purpose, it crawls backwards to the place where a stone may be, and thrusting its tail under it, is at great pains to get it properly balanced on its back, by an alternate motion of the rings composing its body. When it has succeeded in adjusting the stone, it crawls up the side of the pit with great care and deposits its burden on the outside of the circle. Should the stone happen to be round, the balance can be kept only with the greatest difficulty, as it has to travel with its load upon a slope of loose sand which is ready to give way at every step; and often when the insect has carried it to the very brink it rolls off its back and tumbles down to the botton of the pit. This accident, so far from discouraging the ant-lion, only stimulates it to more persevering efforts. Bonnet observed it renew these attempts to dislodge a stone, five or six times. It is only when it finds it utterly impossible to succeed, that it abandons the design and commences another pit in a fresh situation. When it succeeds in getting a stone beyond the line of its circle, it is not contented with letting it rest there; but to prevent it from again rolling in, it goes on to push it to a considerable distance.

The pitfall, when finished, is usually about three inches in diameter at the top, about two inches deep, and gradually contracting into a point in the manner of a cone or funnel. In the bottom of this pit the ant-lion stations itself to watch for its prey. Should an ant or any other inscct wander within the verge of the funnel, it can scarcely fail to dislodge and roll down some particles of sand, which will give notice to the 
ant-lion below to be on the alert. In order to secure the prey, Reaumur, Bonnet, and others have observed the ingenious insect throw up showers of sand by jerking it from his head in quick succession, till the luckless ant is precipitated within reach of the jaws of its concealed enemy. It feeds only on the blood or juice of insects; and as soon as it has extracted these, it tosses the dry carcase out of its den. Its next care is to mount the sides of the pitfall and repair any damage it may have suffered; and when this is accomplished, it again buries itself among the sand at the bottom, leaving nothing but its jaws above the surface, ready to seize the next victim.

When it is about to change into a pupa, it proceeds in nearly the same manner as the caterpillar of the water-betony moth (Cuculiia scrophularice). It first builds a case of sand, the particles of which are secured by threads of silk, and then tapestries the whole with a silken web. Within this it undergoes its transformation into a pupa, and in due time, it emerges in form of a four-winged fly, closely resembling the dragon-flies (Libelluloe), vulgarly and erroneously called horse stingers.

The instance of the ant-lion naturally leads us to consider the design of the Author of Tature in so nicely adjusting, in all animals, the means of destruction and of escape: As the larger quadrupeds of prey are provided with a most ingenious machinery for preying on the weaker, so are these furnished with the most admirable powers of evading their destroyers. In the economy of insects, we constantly observe, that the means of defence, not only of the individual creatures, but of their larvæ and pupæ, against the attacks of other insects, and of birds, is proportioned, in the ingenuity of their arrangements, to the weakness of the insect employing them. Those species which multiply the quickest hare the greatest 
number of enemies. Bradley, an English naturalist, has calculated that two sparrows carry, in the course of a week, above three thousand caterpillars to the young in their nests. But though this is, probably, much beyond the truth, it is certain that there is a great and constant destruction of individuals going forward; and yet the species is never destroyed. In this way a balance is kept up, by which one portion of animated nature cannot usurp the means of life and enjoyment which the world offers to another portion. In all matters relating to reproduction, Nature is prodigal in her arrangements. Insects have more stages to pass through before they attain their periect growth than other creatures. The continuation of the species is, therefore, in many cases, provided for by a much larger number of eggs being deposited than ever become fertile. How many larvæ are produced, in comparison with the number which pass into the pupa state; and how many pupæe perish before they become perfect insects! Every garden is covered with caterpillars; and yet how few moths and butterfies, comparatively, are seen, even in the most sumny season! Insects which lay few eggs are, commonly, most remarkable in their contrivances for their preservation. The dangers to which insect life is exposed are manifold; and therefore are the contrivances for its preservation of the most perfect kind, and invariably adapted to the peculiar habits of each tribe. The same wisdom determines the food of every species of insect; and thus some are found to delight in the rose-tree, and some in the oak. Had it been otherwise, the balance of vegetable life would not have been preserved. It is for this reason that the contrivances which an insect employs for obtaining its food are curious, in proportion to the natural diffculties of its structurc. The ant-lion is carnivorous, 
but he has not the quickness of the spider, nor can he spread a net over a large surface, and issue from his citadel to seize a victim which he has caught in his outworks. He is therefore taught to dig a trap, where he sits, like the unwieldy giants of fable, waiting for some feeble one to cross his path. How laborious and patient are his operations-how uncertain the chances of success! Yet he never shrinks from them, because his instinct tells him that by these contrivances alone can he preserve his own existence, and continue that of his species. 


\section{Chapter XII.}

Clothes-Hoth, and other Tent-making Caterpillara.-Leaf and Bark Miners.

There are at least five different species of moths similar in manners and economy, the caterpillars of which feed upon animal substances, such as furs, woollen cloths, silk, leather, and, what to the naturalist is no less vexing, upon the specimens of insects and other animals preserved in his cabinet. The moths in question are of the family named Tinea by Entomologists, such as the tapestry moth (Tinea tapetzella), the fur moth (Tinea pellionella), the wool moth (Tinea vestianella), the cabinet moth (Tinea Destructor, Stephens), \&c.

The moths themselves are, in the winged state, small, and well fitted for making their way through the most minute hole or chink, so that it is scarcely possible to exclude them by the closeness of a wardrobe or a cabinet.* If they cannot effect an entrance when a drawer is out, or a door open, they will contrive to glide through the key-hole; and if they once get in, it is no easy matter to dislodge or destroy them, for they are exceedingly agile, and escape out of sight in a moment. Moufet is of opinion that the ancients possessed an effectual method of preserving stuffs from the moth, because the robes of Servius Tullius were preserved up to the death of Sejanus, a period of more than five hundred years. On iurning to Pliny to learn this secret, we find him relating that stuff laid upon a coffin will be ever after safe from

"See fig. d., p. 221.

vol., $1 \mathrm{~V}$, 
moths; in the same way as a person once stung by a scorpion will never afterwards be stung by a bee, or a wasp, or a hornet! Rhasis again says, that cantharides suspended in a house drive away moths; and, he adds, that they will not touch anything wrapped in a lion's skin!-the poor little insects, says Reaumur sarcastically, being probably in bodily fear of so terrible an animal.* Such are the stories which fill the imagination even of philosophers, till real science entirely expels them.

The effluvium of camphor or turpentine may sometimes kill them, when in the winged state, but this will have no effect upon their eggs, and seldom upon the caterpillars; for they wrap themselves up too closely to be easily reached by any agent except heat. This, when it can be conveniently applied, will be certain either to dislodge or to kill them. When the effluvium of turpentine, however, reaches the caterpillar, Bonnet says it falls into convulsions, becomes covered with livid blotches, and cies. $†$

The mother insect takes care to deposit her eggs on or near such substances as she instinctively foreknows will be best adapted for the food of the young, taking care to distribute them so that there may be a plentiful supply and enough of room for each. We have found, for example, some of those caterpillars feeding upon the shreds of cloth used in training wall-fruit trees; but we never saw more than two caterpillars on one shred. This scattering of the eggs in many places, renders the effect of the caterpillars more injurious, from their attacking many parts of a garment or a piece of stuff at the same timet.

When one of the caterpillars of this family issues

* Réaunur, Y'em. Hist. Insects, iii. 70.

† Contemplation de la Nature, part xii. chap. x. note. 
from the egg, its first care is to provide itself with a domicile, which indeed seems no less indespensable to it than food; for, like all caterpillars that feed under cover, it will not eat while it remains unprotected. Its mode of building is very similar to that which is employed by other caterpillars that make use of extraneous materials. The foundation or frame-work is made of silk secreted by itself, and into this it interweaves portions of the material upon which it feeds. It is said by Bingley, that "after having spun a fine coating of silk immediately around its body, it cuts the filaments of the wool or fur close by the thread of the cloth, or by the skin, with its teeth, which act in the manner of scissors, into convenient lengths, and applies the bits, one by one, with great dexterity, to the outside of its silken case." "This statement, however, is erroneous, and inconsistent with the proceedings not only of the clothes moth, but of every caterpillar that constructs a covering. None of these build from within outwards, but uniformly commence with the exterior wall, and finish by lining the interior with the finest materials. Reaumur, however, found that the newlyhatched caterpillars lived at first in a case of silk.

We have repeatedly witnessed the proceedings of these insects from the very foundation of their structures; and, at the moment of writing this, we turned out one from the carcase of an "old lady moth" (Mormo maura, Ochsenheim,) in our cabinet, and placed it on a desk covered with green cloth, where it might find materials for constructing another dwelling. It wandered about for half a day before it began its operations; but it did not, as is asserted by Bonnet, and Kirby and Spence, " in moving from place to place, seem to be as much incommoded by

* Animal Biography, vol. iii. p. 330, 3d ed. 
the long hairs which surrounded it, as we are by walking amongst high grass," nor " accordingly, marching scythe in hand," did it, "with its teeth, cut out a smooth road." "* On the contrary, it did not cut a single hair, till it selected one for the foundation of its intended structure. This it cut very near the cloth, in order, we suppose, to have it as long as possible; and placed it on a line with its body. It then immediately cut another, and placing it parallel to the first, bound both together with a few threads of its own silk. The same process was repeated with other hairs, till the little creature had made a fabric of some thickness, and this it went on to extend till it was large enough to cover its body; which (as is usual with caterpillars) it employed as a model and measure for regulating its operations. We remarked that it made choice of longer hairs for the outside than for the parts of the interior, which it thought necessary to strengthen by fresh additions; but the chamber was ultimately finished by a fine and closelywoven tapestry of silk. We could see the progress of its work, by looking into the opening at either of the ends; for at this stage of the structure the walls are quite opaque, and the insect concealed. It may be thus observed to turn round, by doubling itself and bringing its head where the tail had just been; of course, the interior is left wide enough for this purpose, and the centre, indeed, where it turns, is always wider than the extremities. $\dagger$

When the caterpillar increases in length, it takes care to add to the length of its house, by working-in fresh hairs at either end; and if it be shifted to stuffs of different colours, it may be made to construct a party-coloured tissue, like a Scotch plaid. Réaumur cut off with scissors a portion at each end, to compel

* Bonnet, xi. p. 204, Kirby and Spence, Intro. i. 461. 5th ed. † J. R. 
the insect to make up the deficiency. But the caterpillar increases in thickness as well as in length, so that its first house becoming too narrow, it must either enlarge it, or build a new one. It prefers the former as less troublesome, and accomplishes its purpose " as dexterously," says Bonnet, " as any tailor, and sets to work precisely as we should do, slitting the case on the two opposite sides, and then adroitly inserting between them two pieces of the requisite size.

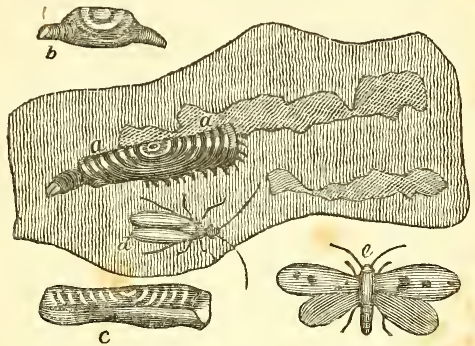

Cases, \&c. of the Clothes-Moth (Tinea pellionella)-ap Caterillar feeding in a case, which has been Jengthened by ovals of different colours. $b$ Case cut at the ends for experiment. $c$ Case cut open, by the insect, for enlarging it. $d, e$ 'The clothes-Moths in their perfect state, when, as they cease to eat, they do no further injury.

It does not, however, cut open the case from one end to the other at once; the sides would separate too far asunder, and the insect be left naked. It therefore first cuts each side about half way down, beginning sometimes at the centre and sometimes at the end, (Fig. c.) and then, after having filled up the fissure, proceeds to cut the remaining half; so that, in fact, four enlargements are made, and four separate pieces inserted. The colour of the case is always the same as that of the stuff from which it is taken. Thus, if

voL. IV. 
its original colour be blue, and the insect previously to enlarging it be put upon red cloth, the circles at the end, and two stripes down the middle, will be red." Reaumur found that they cut these enlargements in no precise order, but sometimes continuously, and sometimes opposite each other, indifferently.

The same naturalist says he never knew one leave its dwelling in order to build a new, though, when once ejected by force from its house, it would never enter it again, as some other species of caterpillars will do, but always preferred building another. We, on the contrary, have more than once seen them leave an old habitation. The very caterpillar, indeed, whose history we have above given, first took up its abode in a specimen of the ghost-moth (Htpialus humuli), where finding few suitable materials for building, it had recourse to the cork of the drawer, with the chips of which it made a structure almost as warm as it would have done from wool. Whether it took offence at our disturbing it one day, or whether it did not find suficient food in the body of the ghostmoth, we know not; but it left its cork house, and travelled about eighteen inches, selected " the old lady," one of the largest insects in the drawer, and built a new apartment composed partly of cork as before, and partly of bits clipt out of the moth's wings. $†$

We have seen these caterpillars form their habitations of every sort of insect, fiom a butterfly to a beetle; and the soft feathery wings of moths answer their purpose very well: but when they fall in with such hard materials as the musk beetle (Cerambyx moschatus) or the large scolopendra of the West Indies, they find some difficulty in the building.

When the structure is finished, the insect deems

* Bonnet, vol. ix. p. 203.

+ J. R. 
itself secure to feed on the materials of the cloth or other animal matter within its reach, provided it is dry and free from fat or grease, which Reaumur found it would not touch. For building, it always selects the straightest and loosest pieces of wool, but for food it prefers the shortest and most compact; and to procure these it eats into the body of the stuff, rejecting the pile or nap, which it necessarily cuts across at the origin, and permits to fall, leaving it threadbare, as if it had been much worn. It must have been this circumstance which induced Bonnet to fancy (as we have already mentioned) that it cut the hairs to make itself a smooth comfortable path to walk upon. It would be equally correct to say that an ox or a sheep dislikes walking amongst long grass, and therefore eats it down in order to clear the way.

\section{Tent-making Caterpillars.}

The caterpillars of a family of small moths ( Tinei$d(\varepsilon)$, which feed on the leaves of various trees, such as the hawthorn, the elm, the oak, and most fruit-trees particularly the pear, form habitations which are exceedingly ingenious and elegant. 'They are so very minute that they require close inspection to discover them; and to the cursory observer, unacquainted with their habits, they will appear more like the withered leaf scales of the tree, thrown off when the buds expand, than artificial structures made by insects. It is only, indeed, by seeing them move about upon the leaves, that we discover they are inhabited by a living tenant, who carries them as the snail does its shell.

These tents are from a quarter of an inch to an inch in length, and usually about the breadth of an oat-straw. That they are of the colour of a withered 
leaf is not surprising; for they are actually composed of a piece of leaf; not, however, cut out from the whole thickness, but artfully separated from the upper layer, as a person might separate one of the leaves of paper from sheet of pasteboard.

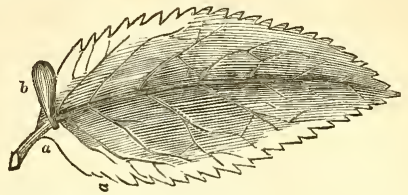

A caterpillar's tent upon a leaf of the elm. $\alpha, a$ the part of the leaf from which the tent has been cut out. $b$, the tent itself.

The tents of this clasis of caterpillars, which are found on the elm, the alder, and other trees with serrated leaves, are much in the shape of a minute gold-fish. They are convex on the back, where the indentations of the leaf out of which they have been cut add to the resemblance, by appearing like the dorsal fins of the fish. By depriving one of those caterpillars common on the hawthorn of its tent, for the sake of experiment, we put it under the necessity of making another; for, as Pliny remarks of the clothes-moth, they will rather die of hunger than feed unprotected. When we placed it on a fresh hawthorn leaf, it repeatedly examined every part of it, as if seeking for its lost tent, though, when this was put in its way, it would not again enter it; but, after some delay, commenced a new one.*

For this purpose, it began to eat through one of the two outer membranes which compose the leaf and enclose the pulp (parenchyma), some of which, also, it devoured, and then thrust the hinder part

$$
\text { * J. R. }
$$


of its body into the perforation. The cavity, however, which it had formed, being yet too small for its reception, it immediately resumed the task of making it larger. By continuing to gnaw into the pulp, between the membranes of the leaf (for it took the greatest care not to puncture or injure the membranes themselves), it soon succeeded in mining out a gallery rather larger than was sufficient to contain its body. We perceived that it did not throw out as rubbish the pulp it dug into, but devoured it as food, -a circumstance not the least remarkable in its proceedings.

As the two membranes of leaf thus deprived of the enclosed pulp appeared white and transparent, every movement of the insect within could be distinctly seen; and it was not a little interesting to watch its ingenious operations while it was making its tent from the membranes prepared as we have just described. These, as Réaunur has remarked, are in fact to the insect like a piece of cloth in the hands of a tailor; and no tailor could cut out a shape with more neatness and dexterity than this little workman does. As the caterpillar is furnished in its mandibles with an excellent pair of scissors, this may not appear to be a difficult task; yet, when we examine the matter more minutely, we find that the peculiar shape of the two extremities requires different curvatures, and this, of course, renders the operation no less complex, as Reaumur subjoins, than the shaping of the pieces of cloth for a coat.* The insect, in fact, shapes the membranes slightly convex on one side and concave on the other, and at one end twice as large as at the other. In the instance which we observed, beginning at the larger end, it bent them gently on each side by pressing them with its body thrown into a curve. We have not said it culs, but shapes its materials; for it must be obvious that if the insect had cut both the

* Mer. Uist. Insect. iii. p. 106. 
membranes at this stage of its operations, the pieces would have fallen and carried it along with them.

To obviate such an accident, it proceeded to join the two edges, and secure them firmly with silk, before it made a single incision to detach them. When it had in this manner joined the two edges along one of the sides, it inserted its head on the outside of the joining, first at one end and then at the other, gnawing the fibres till that whole side was separated. It proceeded in the same manner with the other side, joining the edges before it cut them; and when it arrived at the last fibre, the only remaining support of its now finished tent, it took the precaution, before snipping it, to moor the whole to the uncut part of the leaf by a cable of its own silk. Consequently, when it does cut the last nervure, it is secure from falling, and can then travel along the leaf, carrying its tent on its back, as a snail does its shell.*

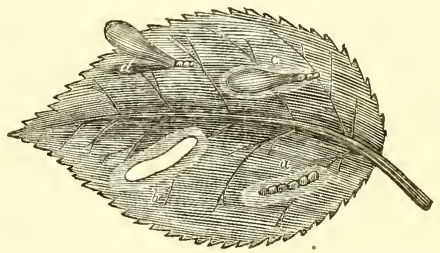

$\boldsymbol{a}$ The caterpillar occupying the space it has eaten between the cuticle of the leaf. $b$ A portion of the upper cuticle, cut out for the formation of the tent. $c$ The tent nearly completed. $d$ The perfect tent, with the caterpillar protruding its head.

We have just discovered (Nov 4th, 1829), upon the nettle, a tent of a very singular appearance, in consequence of the materials of which it is made. The caterpillar seems, indeed, to have proceeded ex- 
actly in the same manner as those which we have described, mining first between the two membranes of the leaf, and then uniting these and cutting out his tent. But the tent itself looks singular from being all over studded with the stinging bristles of the nettle, and forming a no less formidable coat of mail to the little inhabitant, than the spiny hide of the hedgehog. In feeding, it does not seem to have mined into the leaf, but to have eaten the whole of the lower membrane, along with the entire pulp, leaving nothing but the upper membrane untouched.*

\section{Tents of Stonemason Caterpillars.}

The caterpillar of a small moth (Tinea) which feeds upon the lichens growing on walls, builds for itself a moveable tent of a very singular kind. M. de la Voye was the first who described these insects; but though they are frequently overlooked, from being very small, they are by no means uncommon on old walls. Reaumur observed them regularly for twenty years together, on the terrace-wall of the Tuileries at Paris; and they may be found in abundance in similar situations in this country. This accurate observer refuted by experiment the notion of M. de la Voye, that the caterpillars fed upon the stones of the wall; but he satisfied himself that they detached particles of the stone for the purpose of building their tents or sheaths (fourreaux), as he calls their dwellings. In order to watch their mode of building, Réaumur gently ejected half a dozen of them from their homes, and observed them detach grain after grain from a piece of stone, binding each into the wall of their building with silk, till the cell acquired the requisite magnitude, the whole operation taking about twenty-four hours of continued labour. MI. de la Voye mentions small 
granular bodies of a greenish colour, placed irregularly on the exterior of the structure, which he calls eggs; but we agree with Réaumur in thinking it more probable that they are small fragments of moss or lichen intermixed with the stone: in fact, we have ascertained that they are so.*

When these little architects prepare for their change into chrysalides before becoming moths, they attach their tents securely to the stone over which they have hitherto rambled, by spinning a strong mooring of silk, so as not only to fill up every interstice between the main entrance of the tent and the stone, but also weaving a close, thick curtain of the same material, to shut up the entire aperture.
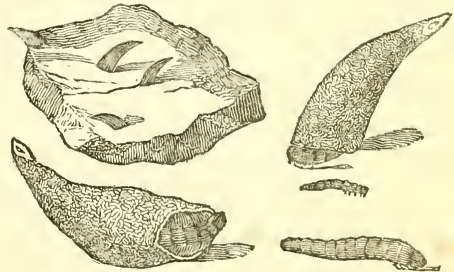

Tents and Caterpillars, both of their natural size and magnified.

It is usual for insects which form similar structures, to issue, when they assume the winged state, from the broader end of their habitation; but our little stone-mason proceeds in a different manner. It leaves open the apex of the cone from the first, for the purpose of ejecting its excrements, and latterly it enlarges this opening a little, to allow of a free exit when it acquires wings; taking care, however, to spin over it a canopy of silk, as a temporary protection, which it can aficrwards burst through with- 
out difficulty. The moth itself is very much like the common clothes-moth in form; but is of a gilded bronze colour, and considerably smaller.

In the same locality, M. de Maupertuis found a numerous brood of small eaterpillars, which employed grains of stone, not, like the preceding, for building feeding tents, but for their cocoons. This caterpillar was of a brownish-grey colour, with a white line along the back, on each side of which were tufts of hair. The cocoons which it built were oval, and less in size than a hazel nut, the grains of the stone being skilfully woven into irregular meshes of silk.

In June, 1829, we found a numerous encampment of the tent-building caterpillars described by MIM. de la Voye and Reaumur, on the brick wall of a garden at Blackheath, Kent.* They were so very small, however, and so like the lichen on the wall, that, had not our attention been previously directed to their habits, we should have considered them as portions of the wall; for not one of them was in motion, and it was only by the neat, turbinated, conical form in which they had constructed their habitations, that we detected them. We tried the experiment above-mentioned, of ejecting one of the caterpillars fiom its tent, in order to watch its proceedings when constructing another; but probably its haste to procure shelter, or the artificial circumstances into which it was thrown, influenced its operations, for it did not form so good a tent as the first, the texture of the walls being much slighter, while it was more rounded at the apex, and of course not so elegant. Réaumur found, in all his similar experiments, that the new structure equalled the old; but most of the trials of this kind which we have made correspond with the inferiority which we have here recorded. The process indeed is the same,

$$
\text { * J. R. }
$$

TOL IV. 
but it seems to be done with more hurry and less care. It may be, indeed, in some cases, that the supply of silk necessary to unite the bits of stone, earth, or lichen employed, is too scanty for perfecting a second structure.

We remarked a very singular circumstance in the operations of our little architect, which seems to have escaped the minute and accurate attention of Réaunur. When it commenced its structure, it was indispensable to lay a foundation for the walls about to be reared; but as the tent was to be moveable like the shell of a snail, and not stationary, it would not have answered its end to cement the foundation to the wall. We had foreseen this difficulty, and felt not a little interested in discovering how it would be got over. Accordingly, upon watching its movements with some attention, we were soon gratified to perceive that it used its own body as the primary support of the building. It fixed a thread of silk upon one of its right feet, warped it over to the corresponding left foot, and upon the thread thus stretched between the two feet, it glued grains of stone and chips of lichen, till the wall was of the required thickness. Upon this, as a foundation, it continued to work till it had formed a small portion in form of a parallelogram; and, proceeding in a similar way, it was not long in making a ring a very little wider than sufficient to admit its body. It extended this ring in breadth, by working on the inside only, narrowing the diameter by degrees, till it began to take the form of a cone. The apex of this cone was not closed up, but left as an aperture through which to eject its excrements.

It is worthy of remark, that one of the caterpillars which we deprived of its tent, attempted to save itself the trouble of building a new one, by cndeavouring to unhouse one of its neighbours. For this purpose, 
it got upon the outside of the inhabited tent, and sliding its head down to the entrance, tried to make its way into the interior. But the rightful owner did not choose to give up his premises so easily; and fixed his tent down so firmly upon the table where we had placed it, that the intruder was forced to abandon his attempt. The instant, however, that the other unmoored his tent and began to move about, the invader renewed his efforts to eject him, persevering in the struggle for several hours, but without a chance of success. At one time, we imagined that he would have accomplished his felonious intentions; for he bound down the apex of the tent to the table with cables of silk. But he attempted his entrance at the wrong end. He ought to have tried the aperture in the apex, by enlarging which a little he would undoubtedly have made good his entrance; and as the inhabitant could not have turned upon him for want of room, the castle must have been surrendered. This experiment, hovever, was not tried, and there was no hope for him at the main entrance.

\section{Muff-shaped Tents.}

The ingenuity of man has pressed into his service not only the wool, the hair, and even the skins of animals, but has most extensively searched the vegetable kingdom for the materials of his clothing. In all this, however, he is rivalled by the tiny inhabitants of the insect world, as we have already seen; and we are about now to give an additional instance of the art of a species of caterpillars which select a warmer material for their tents than even the caterpillar of the clothes-moth. It may have been remarked by many who are not botanists, that the seed-catkins of the willow become, as they ripen, covered with a species of down or cotton, which, however, is too 
short in the fibre to be advantageously employed in our manufactures. But the caterpillars to which we have alluded, find it well adapted for their habitations.

The muff-looking tent in which we find these insects, does not require much trouble to construct; for the caterpillar does not, like the clothes-moth caterpillar, join the willow-cotton together, fibre by fibre-it is contented with the state in which it finds it on the seed. Into this it burrows, lines the interior with a tapestry of silk, and then detaches the whole from the branch where it was growing, and carries it about with it as a protection while it is feeding. *

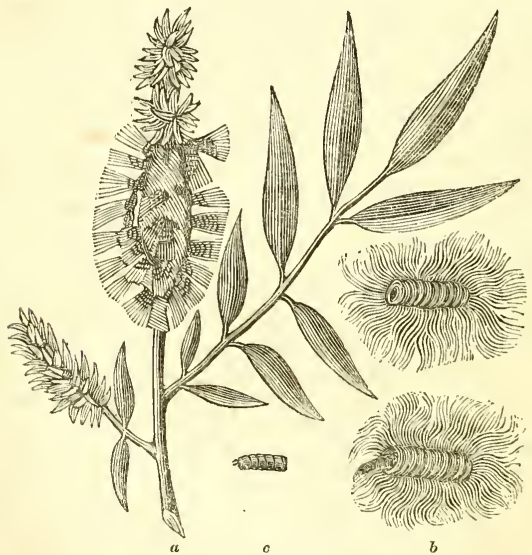

$a$, branch of the willow, with seed spike covered with cotton.

$b$, muff tents made of this cotton by $c$, the caterpillar.

* Réaumur, iii. p. 130. 
An inquiring friend of Réaumur having found one of these insects floating about in its muff-tent upon water, concluded that they fed upon aquatic plants; but he was soon convinced that it had only been blown down by an accident, which must frequently happen, as willows so often hang over water. May it not be, that the buoyant materials of the tent were intended to furnish the little inhabitant with a life-boat, in which, when it chanced to be blown into the water, it might sail safely ashore and regain its native tree?

\section{Leaf-Mining Caterpillaks.}

The process of mining between the two membranes of a leaf is carried on to more extent by minute caterpillars allied to the tent-makers above described. The tent-maker never deserts his house, except when compelled, and therefore can only mine to about half the length of his own body; but the miners now to be considered make the mine itself their dwelling-place, and as they eat their way they lengthen and enlarge their galleries. A few of these mining caterpillars are the progeny of small weevils (Curculionida), some of two-winged flies (Diptera), but the greater number are produced from a genus of minute moths (Ecophora, LATr.) which, when magnified, appear to be amongst the most splendid and brilliant of nature's productions, vying even with the humming birds and diamond beetles of the tropics in the rich metallic colours which bespangle their wings. Well may Bonnet call them "tiny miracles of nature," and regret that they are not en grand.*

There are few plants or trees whose leaves may not, at some season of the year, be found mined by these

* Bonnet, Contempl. de la Nature, Part xii.

VOL. IV.

20* 
caterpillars, the track of whose progress appears on the upper surface in winding lines. Let us take one of the most common of these for an example, - that of the rose-leaf, produced by the caterpillar of Ray's golden-silver spot (Argyromiges Rayella? Curtis) of which we have just gathered above a dozen specimens from one rose tree.*

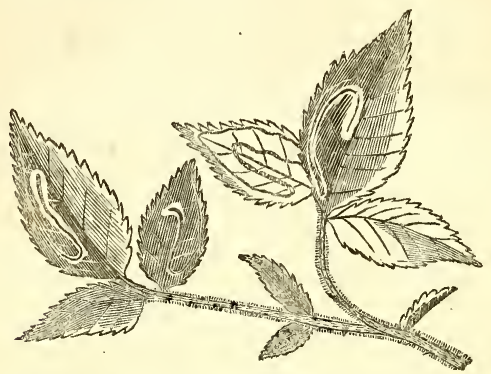

Leaf of the Monthly-Rose (Rosa Indica) mined by Caterpillars of Argyromiges?

It may be remarked, that the winding line is black, closely resembling the tortuous course of a river on a map,-beginning like a small brook, and gradually increasing in breadth as it proceeds. This representation of a river exhibits, besides, a narrow white valley on each side of it, increasing as it goes, till it terminates in a broad delta. The valley is the portion of the inner leaf from which the caterpillar has eaten the pulp (parenchyma), while the river itself has been formed by the liquid ejactamenta of the insect, the watery part becoming evaporated. In other species of miners, however, the dung is liard

$$
\text { * J. R. }
$$


and dry, and consequently these only exhibit the valley without the river. (See p. 237.)

On looking at the back of the leaf, where the winding line begins, we uniformly find the shell of the very minute egg from which the caterpillar has been hatched, and hence perceive that it digs into the leaf the moment it escapes from the egg, without wandering a hair's breadth from the spot; as if afraid lest the air should visit it too roughly. The egg is, for the most part, placed upon the midrib of the roseleaf, but sometimes on one of the larger nervures. When once it has got within the leaf, it seems to pursue no certain direction, sometimes working to the centre, sometimes to the circumference, sometimes to the point, and sometimes to the base, and even, occasionally, crossing or keeping parallel to its own previous track.

The most marvellous circumstance, however, is the minuteness of its workmanship; for though a rose leaf is thinner than this paper, the insect finds room to mine a tunnel to live in, and plenty of food, without touching the two external membranes. Let any one try with the nicest dissecting instruments to separate the two plates of a rose leaf, and he will find it impossible to proceed far without tearing one or other. The caterpillar goes still further in minute nicety; for it may be remarked, that its track can only be seen on the upper, and not on the under surface of the leaf, proving that it eats as it proceeds only half the thickness of the pulp, or that portion of it which belongs to the upper mombrane of the leaf.

We have found this little miner on almost every sort of rose-tree, both wild and cultivated, including the sweet-briar, in which the leaf being very small, it requires nearly the whole parenchyma to feed one caterpillar. They seem, however, to prefer the foreign 
monthly rose to any of our native species, and there are few trees of this where they may not be discovered.

Tunnels, very analogous to the preceding, may be found upon the common bramble (Rubus fruticosus), but the little miner seems to proceed more regularly, always, when newly hatched, making directly for the circumference, upon or near which also the mother moth deposits her egg, and winding along for half the extent of the leaf close upon the edge, following, in some cases, the very indentations formed by the terminating nervures.

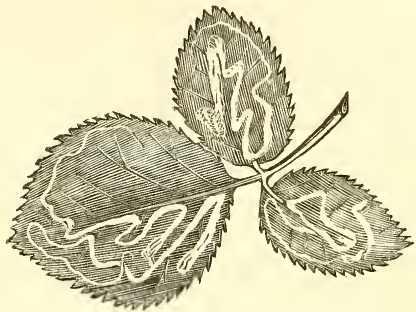

Leaf of the Dew-berry Bramble (Rubus casius) mined by Caterpillars.

The bramble-leaf miner seems also to differ from that of the rose-leaf, by eating the pulp both from the upper and under surface, at least the track is equally distinct above and below; yet this may arise from the different consistence of the leaf pulp, that in the rose being firm, while that of the bramble is soft and puffy.

On the leaves of the common primrose (Primula veris), as well as on the garden variety of it, tho polyanthus, one of those mining caterpillars may very frequently be found. It is, however, considerably 
different from the preceding, for there is no black trace-no river to the valley which it excavates: its ejectamenta, being small and solid, are seen, when the leaf is dried, in little black points like grains of sand. This miner, also, seems more partial than the preceding to the midrib and its vicinity, in consequence of which its path is seldom so tortuous, and often appears at its extremity to terminate in an area, comparatively extensive, arising from its recrossing its previous tracks.*

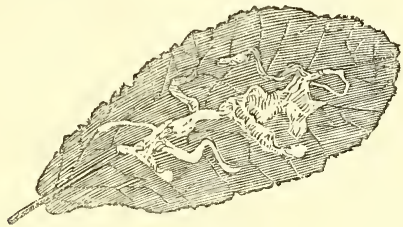

Lexf of the Primrose (Primula veris) mined by a Caterpillar.

Swammerdam describes a mining caterpillar which he found on the leaves of the alder, though it did not, like those we have just described, excavate a winding gallery; it kept upon the same spot, and formed only an irregular area. A moth was produced from this, whose upper wings, he says, "shone and glittered most gloriously with crescents of gold, silver, and brown, surrounded by borders of delicate black." Another area miner which he found on the leaves of willows, as many as seventeen on one leaf, producing what appeared to be rusty spots, was metamorphosed into a very minute weevil (Curculio Rhinoc.). He says he has been informed,

$\rightarrow$ J. R. 
that, in warm climates, worms are found in leaves an inch long, and adds, with great simplicity, " on these many fine experiments might have been made, if the inhabitants had not laboured under the cursed thirst of gold.*"

The vine-leaf miner, when about to construct its cocoon, cuts, from the termination of its gallery, two pieces of the membrane of the leaf, deprived of their pulp, in a similar manner to the tent-makers described above, uniting them and lining them with silk. This she carries to some distance before she lays herself up to undergo her change. Her mode of walking under her burthen is peculiar, for, not contented with the security of a single thread of silk, she forms, as Bonnet says, "little mountains (monticules) of silk, from distance to distance, and seizing one of these with her teeth, drags herself forward, and makes it a scaffolding from which she can build another."' $†$ Some of the miners, however, do not leave their galleries, but undergo their transformations there, taking the precaution to mine a cell, not in the upper, but in the under surface of the leaf; others only shift to another portion of the leaf.

\section{Social Leaf-Miners.}

The preceding descriptions apply to caterpillars who construct their mines in solitude, there being seldom more than one on a leaf or leaflet, unless when two mother flies happen to lay their eggs on the same leaf; but there are others, such as the miners of the leaves of the henbane (Hyoscyamus niger) which excavate a common area in concert-from four to eight forming a colony. These are very like flesh maggots, being larger than the common miners; the

* Swammerd. Book of Nature, vol. ii. p. 84.

+ Contempl. de la Nature, part xii. p. 197. 
leaves of this plant, from being thick and juicy, giving them space to work and plenty to eat.

Most of the solitary leaf-niners either cannot or will not construct a new mine, if ejected by an experimenter from the old, as we have frequently proved; but this is not the case with the social miners of the henbane leal: Bonnet ejected one of these, and watched it with his glass till it commenced a new tunnel, which it also enlarged with great expedition; and in order to verify the assertion of Réaumur, that they neither endeavour nor fear to meet one another, he introduced a second. Neither of them manifested any knowledge of the other's contiguity, but both worked hard at the gallery, as did a third and a fourth which he afterwards introduced; for though they seemed uneasy, they never attacked one another, as the solitary ones often do when they meet.*

\section{Birk-mining Caterpillars.}

A very different order of mining caterpillars are the progeny of various beetles, which excavate their galleries in the soft inner bark of trees, or between it and the young wood (Albuinum). Some of these, though small, commit extensive ravages, as may readily be conceived when we are told that as many as eighty thousand are occasionally found on one tree. In 1783 the trees thus destroyed by the printer beetle (Tomicus typographus, LATr.), so called from its tracks resembling letters, amounted to above a million and a half in the Hartz forest. It appears there periodically, and confines its ravages to the fir. This insect is said to have been found in the neighbourhood of London.

On taking off the bark of decaying poplars and willows, we have frequently met with the tracks of

* Bonnet, Observ. aur les Insectes, vol. ii. p. 425. 
a miner of this order, extending in tortuous pathways, about a quarter of an inch broad, for several feet and even yards in length. The excavation is not circular, but a compressed oval, and crammed throughout with a dark-coloured substance like sawdust - the excrement no doubt of the little miner, who is thereby protected from the attacks of staphylinida, and other predaceous insects, from behind. But though we have found a great number of these subcortical tracks, we have never discovered one of the miners, though they are very probably the grubs of the pretty misk-beetle (Cerambyx moschalus) which is so abundant in the neighbourhood of the trees in question, that the very air in summer is perfumed with their odour.*

Another capricom beetle of this family is no less destructive to bark in its perfect state, than the above are when grubs, as, from its habit of eating round a tree, it cuts the course of the returning sap, and destroys it.

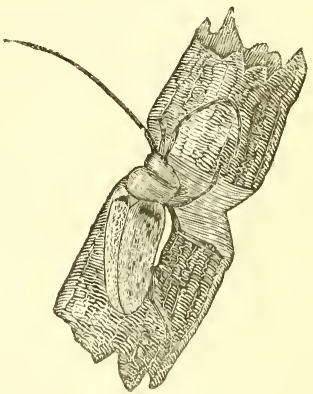

Capricon Butle, (Cerantbyx Eamiat amputrtor) rousding of the Lark of a trie.

* J, R. 


\section{Chapter XIII.}

Structures of Grasshoppers, Crickets, and Beetles.

Grasshoppers, locusts, crickets, and beetles are in many respects, no less interesting than the insects whose architectural proceedings we have already detailed. They do not, indeed, build any edifice for the accommodation of themselves or their progeny; but most, if not all of them, excavate retreats in walls or in the ground.

The house-cricket (Acheta domestica) is well known for its habit of picking out the mortar of ovens and kitchen fire-places, where it not only enjoys warmth, but can procure abundance of food. It is usually supposed that it feeds on bread. M. Latreille says it only eats insects, and it certainly thrives well in houses infested by the cockroach; but we have also known it eat and destroy lamb's-wool stockings, and other woollen stuffs, hung near a fire to dry. It is evidently not fond of hard labour, but prefers those places where the mortar is already loosened, or at least is new, soft, and easily scooped out; and in this way it will dig covert ways from room to room. In summer, crickets often make excursions from the house to the neighbouring fields, and dwell in the crevices of rubbish, or the cracks made in the ground by dry weather, where they chirp as merrily as in the snuggest chimney corner. Whether they ever dig retreats in such circumstances, we lave not ascertained; though it is not improbable they may do so for the purpose of making nests. II. 
Bory St Vincent tells us, that the Spaniards are so fond of crickets that they keep them in cages like singing birds.*

\section{The Mole-Cricket.}

The insect called, from its similarity of habits to the mole, the mole-cricket (Gryllotalpa vulgaris, LATr.) is but too well known in gardens and corn-fields in some parts of England, such as Wiltshire and Hampshire, though it is comparatively rare or unknown in others. It burrows in the ground, and forms extensive galleries similar to those of the mole, though smaller; and these may always be recognised by a slightly-elevated ridge of roould: for the insect does not throw up the earth in hillocks like the mole, but gradually, as it digs along, in the manner of the field mouse. In this way it commits great ravages in hotbeds and in gardens, upon pease, young cabbages, and other vegetables, the roots of which it is said to devour. It is not improbable, we think, that, like its congener, the house-cricket, it may also prey upon underground insects, and undermine the plants to get at them, as the mole has been proved to do. Mr Gould, indeed, fed a mole-cricket for several months upon ants.

The structure of the mole-cricket's arms and hands (if we may call them so) is admirably adapted for these operations, being both very strong, and moved by a peculiar apparatus of muscles. The breast is formed of a thick, hard, horny substance, which is further strengthened within by a double frame-work of strong gristle, in front of the extremities of which the shoulder blades of the arms are firmly jointed; a structure evidently intended to prevent the breast from being injured by the powerful action of the

* Dict. Classique d'Hist. Nát. Art. Grulran. 
muscles of the arms in digging. The arms themselves are strong and broad, and the hand is furnished with four large sharp claws, pointing somewhat obliquely outwards, this being the direction in which it digs, throwing the earth on each side of its course.

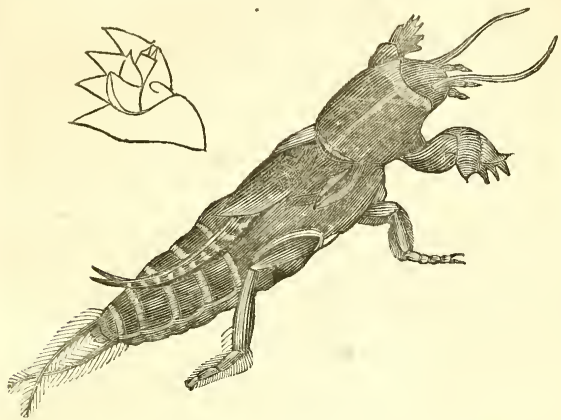

The Mole-Cricket, with a separate outline of one of its hands.

The nest which the female constructs for her eggs, in the beginning of May, is well worthy of attention. The Rev Mr White of Selborne, tells us that a gardener, at a house where he was on a visit, while. mowing grass by the side of a canal, chanced to strike his scythe too deep, and pared off a large piece of turf, laying open to view an interesting scene of domestic economy. There was a pretty chamber dug in the clay, of the form and about the dimensions it would have had if moulded by an egg, the walls being neatly smoothed and polished. In this little cell were deposited about a hundred eggs, of the size and form of caraway comfits, and of a dull tarnished white colour. The eggs were not very deep, 
but just under a little heap of fresh mould, and within the influence of the sun's heat.*

Like the eggs and young of other insects, however, those of the mole-cricket are exposed to depredation, and particularly to the ravages of a black beetle which burrows in similar localities. The mother insect, accordingly, does not think her nest secure till she has defended it, like a fortified town, with labyrinths, entrenchments, ramparts, and covert ways. In some part of these outworks, she stations herself as an advanced guard, and when the beetle ventures within her circumvallations, she pounces upon him and kills him.

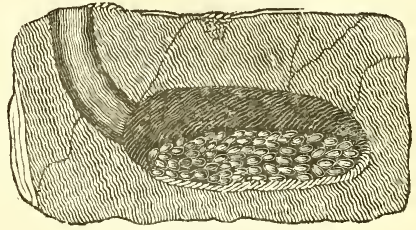

Nest of the Mole-Crichet.

\section{The Freld-Cricket.}

Another insect of this family, the field cricket (Acheta campestris), also forms burrows in the ground, in which it lodges all day, and comes out chiefly about sun-set, to pipe its evening song. It is so very shy and cautious, however, that it is by no means easy to discover either the insect or its burrow. "The children in France amuse themselves with hunting after the field cricket; they put into its hole an ant fastened by a long hair, and as they draw it out the cricket does not fail to pursue it, and issue from its

* Nat. Hist. of Selborne, ii. 82. 
retreat. Pliny informs us it might be captured in a much more expeditious and easy manner. If, for instance, a small and slender piece of stick were to be thrust into the burrow, the insect, he says, would immediately get upon it for the purpose of demanding the occasion of the intrusion: whence arose the proverb stultior grillo (more foolish than a cricket), applied to one who, upon light grounds, provokes his enemy, and falls into the snares which might have been laid to entrap him."

The Rev Mr White, who attentively studied their habits and manners, at first made an attempt to dig them out with a spade, but without any great success; for either the bottom of the hole was inaccessible, from its terminating under a large stone, or else, in breaking up the ground, the poor creature was inadvertently squeezed to death. Out of one thus bruised, a great number of eggs were taken, which were long and narrow, of a yellow colour, and covered with a very tough skin. More gentle means were then used, and these proved successful. A pliant stalk of grass, gently insinuated into the caverns, will probe their windings to the bottom, and bring out the inhabitant; and thus the humane inquirer may' gratify his curiosity without injuring the object of it.

When the males meet, they sometimes fight very fiercely, as Mr White found by some that he put into the crevices of a dry stone wall, where he wished to have them settle. For though they seemed distressed by being taken out of their knowledge, yet the first that got possession of the chinks seized on all the others that were obtruded upon him with his large row of serrated fangs. With their strong jaws, toothed like the shears of a lobster's claws, they perforate and

* Entomologie, par R. A. E., 18mo., Paris, 1826, p. $16 \varepsilon$. VOL. IV. 
round their curious regular cells, having no foreI claws to dig with, like the mole-cricket. When taken into the hand, they never attempt to defend themselves, though armed with such formidable weapons. Of such herbs as grow about the mouths of their burrows, they eat indiscriminately, and never in the day-time seem to stir more than two or three inches from home. Sitting in the entrance of their caverns, they chirp all night as well as day, from the middle of the month of May to the middle of July. In hot weather, when they are most vigorous, they make the hills echo; and, in the more still hours of darkness, may be heard to a very considerable distance. " "Not many summers ago," says Mr White, "I endeavoured to transplant a colony of these insects to the terrace in my garden, by boring deep

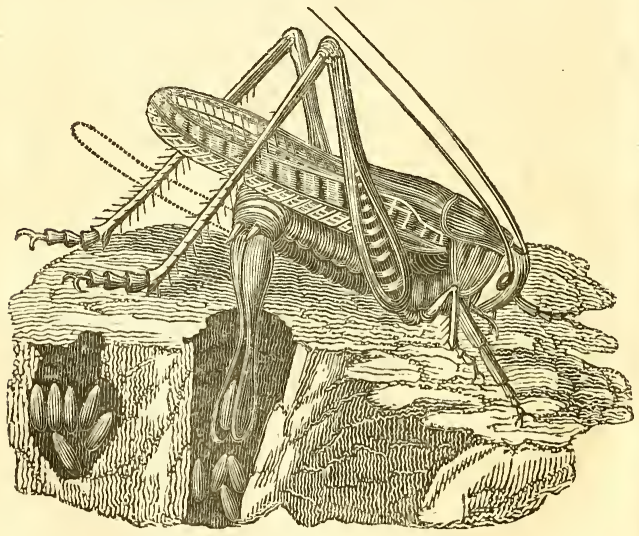

Aorida verrucivora depositing her Eggs.

The usual position of the ovipositor is represented by dots. 
holes in the sloping turf The new inhabitants staid some time, and fed and sang; but they wandered away by degrees, and were heard at a greater distance every morning; so it appears that on this emergency they made use of their wings in attempting to return to the spot from which they were taken." The manner in which these insects lay their eggs is represented in the preceding figure; which is that of an insect nearly allied to the crickets, though of a different genus.

A more laborious task is perforned by an insect by no means uncommon in Britain, the Burying Beetle (Necrophoirus vespillo), which may be easily recognised by its longish body, of a black colour, with two broad and irregularly indented bands of yellowish brown. A foreign naturalist, MI. Gleditsch, gives a very interesting account of its industry. He had " often remarked that dead moles, when laid upon the ground, especially if upon loose earth, were almost sure to disappear in the course of two or three days, often of twelve hours. To ascertain the cause, he placed a mole upon one of the beds in his garden. It had vanished by the third morning; and on digging where it had been laid, he found it buried, to the depth of three inches, and under it four beetles, which seemed to have been the agents, in this singular inhumation. Not perceiving anything particular in the mole, he buried it again; and on examining it at the end of six days, he found it swarming with maggots, apparently the issue of the beetles, which M. Gleditsch now naturally concluded had buried the carcass for the food of their future young. To determine these points more clearly, he put four of these insects into a glass vessel, half filled with earth and properly secured, and, upon the surface of the éarth, two frogs. In less than twelve hours one of the frogs was interred by two of the beetles; the other two ran

* Nat. Hist. Selborne. 
about the whole day, as if busied in measuring the dimensions of the remaining corpse, which on the third day was also found buried. He then introduced a dead linnet. A pair of the beetles were soon engaged upon the bird. They began their operations by pushing out the earth fiom under the body, so as to form a cavity for its reception; and it was curious to see the efforts which the beetles made, by dragging at the feathers of the bird from below, to pull it into its grave. The male, having driven the female away, continued the work alone for five hours. He lifted up the bird, changed its place, turned it and arranged it in the grave, and from time to time came out of the hole, mounted upon it, and trod it under foot, and then retired below, and pulled it down. At length, apparently wearied with this uninterrupted labour, it came forth, and leaned its head upon the earth beside the bird without the smallest motion, as if to rest itself, for a full hour, when it again crept under the earth. The next day, in the morning, the bird was an inch and a half under ground, and the trench remained open the whole day, the corpse seeming as if laid out upon a bier, surrounded with a rampart of mould. In the evening it had sunk half an inch lower, and in another day the work was completed, and the bird covered. M. Gleditsch continued to add other small dead animals, which were all sooner or later buried; and the result of his experiment was, that in fifty days four beetles had interred, in the very small space of earth allotted to them, twelve carcasses: viz., four frogs, three small birds, two fishes, one mole, and two grasshoppers, besides the entrails of a fish, and two morsels of the lungs of an ox. In another experiment, a single beetle buried a mole forty times its own bulk and weight in two days."

* Act. Acad. Berolin. 1752, et Gleditsch, Phys. Botan., quoted by Kirby and Spence, ii. 353 . 
In the summer of 1826, we found on Putney heath, in Surrey, four of these beetles, hard at work in burying a dead crow, precisely in the manner described by M. Gleditsch.*

\section{Dung-Beetle.}

A still more common British insect, the Dorr, Clock, or Dung Peetle (Geotrupes stercorarius), uses different materials for burying along with its eggs. "It digs," to use the words of Kirby and Spence, "a deep cylindrical hole, and carrying down a mass of the dung to the bottom, in it deposits its eggs. And many of the species of the genus Ateuchus roll together wet dung into round pellets, deposit an egg in the midst of each, and when dry push them backwards, by their hind fect, to holes of the surprising depth of three feet, which they have previously dug for their reception, and which are often several yards distant. The attention of these insects to their eggs is so remarkable, that it was observed in the earliest ages, and is mentioned by ancient writers, but with the addition of many fables, as that they were all of the male sex; that they became young again every year; and that they rolled the pellets containing their eggs from sumrise to sunset every day, for twentyeight days without intermission." $\uparrow$

"We frequently notice in our evening walks," says Mr Knapp, " the murmuring passage, and are often stricken by the heedless flight, of the great dorrbeetle (Geotrupes stercorarius), clocks, as the boys call them. But this evening my attention was called to them in particular, by the constant passing of such a number as to constitute something like a little stream; and I was led to search into the object of their direct fight, as in general it is irregular and

* J R. † Mouffet, 153. Kirby and Spence, ii. 350. 
seemingly inquisitive. I soon found that they dropped on some recent nuisance: but what powers of perception must these creatures possess, drawn from all distances and directions by the very little fetor which, in such a calm evening, could be diffised around, and by what inconceivable means could odours reach this beetle in such a manner as to rouse so inert an insect into action! But it is appointed one of the great scavengers of the earth, and marvelously endowed with powers of sensation, and means of effecting this purpose of its being. Exquisitely fabricated as it is to receive impressions, yet probably it is not more highly gifted than any of the other innumerable creatures that wing their way around us, or creep about our paths, though by this one perceptible faculty, thus ' dimly seen,' it excites our wonder and surprise. How wondrous then the whole!

"The perfect cleanliness of these, creatures is a very notable circumstance, when we consider that nearly their whole lives are passed in burrowing in the earth, and removing nuisances; yet such is the admirable polish of their coating and limbs, that we very seldom find any soil adhering to them. The meloe, and some of the scarabæi, upon first emerging from their winter's retreat, are commonly found with earth clinging to them; but the removal of this is one of the first operations of the creature; and all the beetle race, the chief occupation of which is crawling about the soil and such dirty employs, are notwithstanding remarkable for the glossiness of their covering, and freedom from defilements of any kind. But purity of vesture seems to be a principal precept of nature, and observable throughout creation. Fishes, from the nature of the element in which they reside, can contract but little impurity. Birds are unceasingly attentive to neatness and lustration of their plumage. All the slug race, though covered 
with slimy matter calculated to collect extraneous things, and reptiles, are perfectly free from soil. The fur and hair of beasts, in a state of liberty and health, is never filthy, or sullied with dirt. Some birds roll themselves in dust, and, occasionally, particular beasts cover themselves with mire; but this is not from any liking or inclination for such things, but to free themselves from annoyances, or to prevent the bites of insects. Whether birds in preening, and beasts in dressing themselves, be directed by any instinctive faculty, we know not; but they evidently derive pleasure from the operation, and thus this feeling of enjoyment, even if the sole motive, becomes to them an essential source of comfort and of health." "*

The rose or green chafer (Cetonia aurata), which is one of our prettiest native insects, is one of the burrowers, and for the purpose of depositing her eggs, digs, about the middle of June, into soft light ground. When she is seen at this operation, with her broad and delicate wings folded up in their shining green cases, speckled with white, it could hardly be imagined that she had but just descended from the air, or dropped down from some neighbouring rose.

The proceedings of the Tumble-Dung Beetle of America (Scarabceus pilularius, Lins.) are described in a very interesting manner by Catesby, in his 'Carolina." "I have," says he, "attentively adınired their industry, and mutual assisting of each other in rolling their globular balls from the place where they made them to that of their interment, which is usually the distance of some yards, more or less. This they perform breech foremost, by raising their hind parts, and forcing along

* Journal of a Naturalist, p. 311 . 
the ball with their hind feet. Two or three of them are sometimes engaged in trundling one ball, which, from meeting with impediments on account of the unevenness of the ground, is sometimes deserted by them. It is, however, attempted by others with success, unless it happens to roll into some deep hollow or chink, where they are constrained to leave it; but they continue their work by rolling off the next ball that comes in their way. None of them seem to know their own balls, but an equal care for the whole appears to affect all the community. They form these peliets while the dung remains moist, and leave them to harden in the sun before they attempt to roll them. In their moving of them from place to place, both they and the balls may frequently be seen tumbling about over the little eminences that are in their way. They are not, however, easily discouraged; and, by repeating their attempts usually surmount the difficulties."

He further informs us that they "find out their subsistence by the excellency of their noses, which direct them in their flight to newly-fallen dung, on which they immediately go to work, tempering it with a proper mixture of earth. So intent are they always upon their employment, that, though handled or otherwise interrupted, they are not to be deterred, but immediately on being freed, persist in their work without any apprehension of danger. They are said to be so exceedingly strong and active as to move about, with the greatest ease, things that are many times their own weight. Dr Brichell was supping one evening in a planter's house of North Carolina, when two of them were conveyed, without his knowledge, under the candlestick. A few blows were struck on the table, and, to his great surprise, the candlesticks began to move about, apparently without any agencv; and his surprise was not nuch 
lessened when, on taking one of them up, he discovered that it was only a chafer that moved."

We have often found the necklace-beetle (Carabus monilis) inhabiting a chamber dug out in the earth of a garden, just sufficient to contain its body, and carefully smoothed and polished. From the form of this little nest, it would seem as if it were constructed, not by digging out the earth and removing it, but chiefly by the insect pushing its body forcibly against the walls. The beetles which we have found nestling in this manner have been all males; and therefore it cannot be intended for a breeding cell; for male insects are never, we believe, sufficiently generous to their mates to assist them in such labours. The beetle in question appears to be partial to celery trenches;* probably from the loose earth of which they are composed, yielding, without much difficulty, to the pressure of its body.

* J. R. 


\section{Chapter Xiv.}

Arehitecture of Ants.-Mason- $\mathrm{An}$ ts.

ALL the species of ants are social. There are none solitary, as is the case with bees and wasps. They are all more or less skilful in architecture, some en ploying masonry, and others being carpenters, wood. carvers, and miners. They consequently afford muck that is interesting to naturalists who observe their operations. The genuine history of ants has only been recently investigated, first by Gould in 1747, and subsequently by Linnæus, De Geer, IIuber, and Latreille. Previous to that time their real industry, and their imagined foresight, were held up as moral lessons, without any great accuracy of observation; and it is probable that, even now, the mixture of truth and error in Addison's delightful papers in the Guardian (Nos. 156, 157), may be more generally attractive than the minute relations of careful naturalists. Gould disproved, most satisfactorily, the ancient fable of ants storing up corn for winter provision, no species of ants ever eating grain, or feeding in the winter upon anything. It is to Huber the younger, however, that we are chiefly indebted for our knowledge of the habits and economy of ants; and to Latreille for a closer distinction of the species. Some of the more interesting species, whose singular economy is described by the younger Huber, have not been litherto found in this country. We shall, however, diseover matter of very considerable interest in those which are indigenous; and as our principal object is to excite inquiry and observation with regard to those iniects which may be easily watched in our. own girdens and fields, we 
shall chiefly confine ourselves to the ants of these islands. We shall begin with the labours of those native ants which may be called earth-masons, from their digging in the ground, and forming structures with pellets of moistened loam, clay, or sand.

\section{Mason-Axts.}

WE liave used in the preceding pages, the terms mason-bees and mason-uwusp, for insects which build their nests of earthly materials. On the same principle, we have followed the ingenious M. Huber the younger, in employing the term mason-ants for those whose nests on the exterior appear to be hillocks of earth, without the admixture of other materials, whilst in the interior they present a series of labyrinths, lodgcs, vaults, and galleries, constructed with considerable skill. Of these mason-ants, as of the mason-wasps and bees already described, there are several species, differing from one another in their skill in the art of architecture.

One of the most common of the art-masons is the turf-ant (Formica crespilum, LATr.), which is of a blackish brown colour. Its architecture is not upon quite so extensive a scale as some of the others; but, though slight, it is very ingenious. Sometimes they make choice of the shelter of a flat stone or other covering, beneath which they hollow out chambers and communicating galieries; at other times they are contented with the open ground; but most commonly they select a tuft of grass or other herbage, the stems of which serve for columns to their earthen walls.

We had a small colony of these ants aecidentally established in a flower-pot, in which we were rearing some young plants of the tiger-lily (Lilium ligrimum), the stems of which being stronger than the grass where they usually build, enabled them to rear their 
edifice higher, and also to make it more secure, than they otherwise might. It was wholly formed of small grains of moist earth, piled up between the stems of the lily without any apparent cement ; indeed it has been ascertained by Huber, as we shall afterwards see, that they use no cement beside water. This is not always to be procured, as they depend altogether on rains and dew; but they possess the art of joining grains of dry sand so as to support one another, on some similar principle, no doubt, to that of the arch.

The nest which our turf-ants constructed in the flower-pot was externally of an imperfect square form, in consequence of its situation; for they usually prefer a circular plan. The principal chambers were placed under the arches, and, when inspected, contained a pile of cocoons and pupæ. Beneath those upper chambers there were others dug out deeper down, in which were also a numerous collection of eggs and cocoons in various stages of advancement.*

Mr Knapp describes a still more curious structure of another species of ant common in this country:"One year," says he, "on the third of March, my labourer being employed in cutting up ant-hills, or tumps as we call them, exposed to view multitudes of the yellow species (Formica Flava) in their winter's retirement. They were collected in numbers in little cells and compartments communicating with others by means of narrow passages. In many of the cells they had deposited their larva, which they were surrounding and attending, but not brooding over or covering. Being disturbed by our rude operations, they removed then from our sight to more hidden compartments. The larvæ were small. Some of these ant-hills contained multitudes of the young of the wood-louse (Oiniscus armcidillo), inhabiting 
with perfect familiarity the same compartments as the ants, crawling about with great activity with them, and perfectly domesticated with each other. They were small and white; but the constant vibration of their antennæ, and the alacrity of their motions, manifested a healthy vigour. The ants were in a torpid state; but on being removed into a temperate room, they assumed much of their summer's animation. How these creatures are supported during the winter season it is difficult to comprehend; as in no one instance could we perceive any store or provision made for the supply of thei wants. The minute size of the larræ manifested that they had been recently deposited; and consequently that their parents had not remained during winter in a dormant state, and thus free from the calls of hunger. The preceding month of February, and part of January, had been remarkably severe; the frost had penetrated deep into the earth, and long held it frozen; the ants were in many cases not more than four inches beneath the surface, and must have been enclosed in a mass of frozen soil for a long period; yet they, their young, and the onisci, were perfectly uninjured by it: affording another proof of the fallacy of the commonly received opinion, that cold is universally destructive to insect life."*

The earth employed by mason-ants is usually moist clay, either dug from the interior parts of their city, or moistened by rain. The mining-ants and the ash-coloured (Formica fusca) employ earth which is probably not selected with so much care, for it forms a much coarser mortar than what we see used in the structures of the yellow ants ( $\boldsymbol{F}$. flava) and the brown ants $(\boldsymbol{F}$. brunnea). We have never observed them bringing their building materials of this kind from a distance, like the mason-bees and like the

* Journal of a Naturalist, page 304.

vol, IV.

$22^{*}$ 
wood or hill ant ( $\boldsymbol{F} \cdot r u f(a)$; but they take care before they fix upon a locality, that it shall produce them all that they require. $\mathrm{We}$ are indebted to Huber the younger for the most complete account which has hitherto been given of these operations, of which details we shall make free use.

"To form," says this shrewd observer, " a correct judgment of the interior arrangement or distribution of an ant-hill, it is necessary to select such as have not been accidentally spoiled, or whose form has not been too much altered by local circumstances; a slight attention will then suffice to shew, that the habitations of the different species are not all constructed after the same system Thus, the hillock raised by the ash-coloured ants will always present thick walls, fabricated with coarse earth, well-marked stories, and large chambers, with vaulted ceilings, resting upon a solid base. We never observe roads, or galleries, properly so called, but large passages, of an oval form, and all around considerable cavities and extensive embankments of earth. We further notice, that the little architects observe a certain proportion between the large arched ceilings and the pillars that are to support them.

"The brown ant (Formica brunnea), one of the smallest of the ants, is particularly remarkable for the extreme finish of its work. Its body is of a reddish shining brown, its head a little deeper, and the antennæ and feet a little lighter in colour. The abdomen is of an obscure brown, the scale narrow, of a square form, and slightly scolloped. The body is one line and two fifths in length.**

" This ant, one of the most industrious of its tribe, forms its nest of stories, four or five lines in height. The partitions are not more than half a line in thickness; and the substance of which they are composed

* A line is the twelfth part of the old French inch. See Companion to the Almanack for 1830, p. 114. 
is so finely grained, that the inner walls present one smooth unbroken surface. These stories are not horizontal; they follow the slope of the ant-hill, and lie one upon another to the ground-floor, which communicates with the subterranean lodges. They are not always, however, arranged with the same regularity, for these ants do not follow an invariable plan; it appears, on the contrary, that nature has allowed then a certain latitude in this respect, and that they can, according to circumstances, modify them to their wish; but, however fantastical their habitations may appear, we always observe they have been formed by concentrical stories. On examining each story separately, we observe a number of cavities or halls, lodges of narrower dimensions, and long galleries, which serve for general communication. The arched ceilings covering the most spacious places are supported either by little columns, slender walls, or by regular buttresses. We also notice chambers, that have but one entrance, communicating with the lower story, and large open spaces, serving as a kind of cross-road (carrefour), in which all the streets terminate.

"Such is the manner in which the habitations of these ants are constructed. Upon opening them, we commonly find the apartments, as well as the large open spaces, filled with adult ants; and always observe their pupre collected in the apartments more or less near the surface. This, however, seems regulated by the hour of the day, and the temperature: for in this respect these ants are endowed with great sensibility, and know the degree of heat best adapted for their young. The ant-hill contains, sometimes, more than twenty stories in its upper portion, and at least as many under the surface of the ground. By this arrangement the ants are enabled with the greatest facility, to regulate the heat. When a too burning sun over-heats their upper apartments, they withdraw 
their little ones to the bottom of the ant-hill. The ground-floor becoming, in its turn, uninhabitable during the rainy season, the ants of this species transport what most interests them to the higher stories; and it is there we find them more usually assembled, with their eggs and pupæ, when the subterranean apartments are submerged." $*$

Ants have a great dislike to water when it exceeds that of a light shower to moisten their building materials. One species, mentioned by De Azara as indigenous to South America, instinctively builds a nest from three to six feet high, $\dagger$ to provide against the inundations during the rainy season. Even this, however, does not always save them from submersion; and when that occurs, they are compelled, in order to prevent themselves from being swept away, to form a group, somewhat similar to the curtain of the wax-workers of hive-bees (see page 114). The ants constituting the basis of this group, lay hold of some shrub for security, while their companions hold on by them; and thus the whole colony, forming an animated raft, floats on the surface of the water till the inundation (which seldom continues longer than a day or two) subsides.

It is usual with architectural insects to employ some animal secretion, by way of mortar or size, to temper the materials with which they work; but the whole economy of ants is so different, that it would be wrong to infer from analogy a similarity in this respect, though the exquisite polish and extreme delicacy of finish in their structures, lead, naturally, to such a conclusion. M. P. Huber, in order to resolve this question, at first thought of subjecting the materials of the walls to chemical analysis, but wisely (as we think) abandoned it for the surer method of observation. The details which he has given, as the

* M. P. Huber on Ants, page 20.

† Stedman's Surinam, vol. i. p. 160. 
result of his researches, are exceedingly curious and instructive. He began by observing an ant-hill till he could perceive sone change in its form.

"The inhabitants," says he, "of that which I selected, kept within during the day, or only went out by subterranean galleries which opened at some feet distance in the meadow. There were, however, two or three small openings on the surface of the nest; but I saw none of the labourers pass out this way, on account of their being too much exposed to the sun, which these insects greatly dread. This ant hill, which had a round form, rose in the grass, at the border of a path, and had sustained no injury. I soon perceived that the freshness of the air and the dew invited the ants to walk over the surface of their nest; they began making new apertures; several ants might be seen arriving at the same time, thrusting their heads from the entrances, moving about their antennæ, and at length adventuring forth to visit the environs.

"This brought to my recollection a singular opinion of the ancients. They believed that ants were occupied in their architectural labours during the night, when the moon was at its full." *

M. Latreille discovered a species of ants which were, so far as he could ascertain, completely blind, $\uparrow$ and of course it would be immaterial to them whether they worked by night or during the day. All observers indeed agree that ants labour in the night, and a French naturalist is therefore of opinion that they never sleep, - a circumstance which is well ascertained with respect to other animals, such as the shark, which will track a ship in full sail for weeks together.; The ingenious historian of English ants,

* M. P. Huber on ants, p. 23.

+ Latreille, 1 list. Nat. des Fourmis.

I Dr Cleghorn, 'I hesis de Somuo. 
Gould, says they never intermit their labours by night or by day, except when compelled by excessive rains. It is probable the ancients were mistaken in asserting that they only work when the moon shines; ${ }^{*}$ for, like bees, they seem to find no diffieulty in building in the dark, their subterranean apartments being as well finished as the upper 'stories of their buildings. But to proceed with the narrative of M. P. Huber.

"Having thus noticed the movements of these insects during the night, I found they were almost always abroad and engaged about the dome of their habitation after sunset. This was directly the reverse of what I had observed in the conduct of the woodants, $(F \cdot r u f a$, who only go out during the day, and close their doors in the evening. The contrast was still more remarkable than I had previously supposed; for upon visiting the brown ants some days after, during a gentle rain, I saw all their architectural talents in full play.

"As soon as the rain commenced, they left in great numbers their subterranean residence, re-entered it almost immediately, and then returned, bearing between their teeth pellets of earth, which they deposited on the roof of their nest. I could not at first conceive what this was meant for, but at length $I$ saw little walls start up on all sides with spaces lefi between them. In several places, columns, ranged at regular distances, announced halls, lodges, and passages, which the ants proposed establishing; in a word, it was the rough beginning of a new story.

"I watehed with a considerable degree of interest the most trifing movements of my masons, and found they did not work after the manner of wasps

* Arístotle, Ilist. Animal, ix. 38. Pliny says "S Operantur et noctu plen ר lun ‘; eaden interlunio cessant,', i. $e$. 'They work in the night at full moon, but they leave off between inoon and moon. It is the latter that we think doubtful. 
and humble-bees, when occupied in constructing a covering to their nest. The latter sit, as it were, astride on the border or margin of the covering, and take it between their teeth to model and attenuate it according to their wish. The wax of whieh it is composed, and the paper which the wasp employs, moistened by some kind of glue, are admirably adapted for this purpose, but the earth of which the ants make use, from its often possessing little tenacity, must be worked up after some other manner.

"Each ant, then, carried between its teeth the pellet of earth it had formed by scraping with the end of its mandibles the bottom of its abode, a circumstance which $I$ have frequently witnessed in open day. This little mass of earth, being composed of particles but just united, could be readily kneaded and moulded as the ants wished; thus, when they had applied it to the spot where they had to rest, they divided and pressed against it with their teeth, so as to fill up the little inequalities of their wall. The antennæe followed all their movements, passing over each particle of earth as soon as it was placed in its proper position. The whole was then rendered more compact, by pressing it lightly with the forefeet. This work went on remarkably fast. After having traced out the plan of their masonry, in laying here and there foundations for the pillars and partitions they were about to erect, they raised them gradually higher, by adding fresh materials. It oftened happened that two little walls, which were to form a gallery, were raised opposite, and at a slight distance from, each other. When they had attained the height of four or five lines, the ants busied themselves in covering in the space left between them by a vaulted ceiling.

"As if they judged all their partitions of suficient elevation, they then quitted their labours in the 
upper part of the building; they affixed to the interior and upper part of each wall, fragments of moistened earth, in an almost horizontal direction, and in such a way as to form a ledge, which, by extension, would be made to join that coming from the opposite wall. These ledges were about half a line in thickness; and the breadth of the galleries was, for the most part, about a qua:ter of an inch. On one side several vertical partitions were seen to form the scuffolding of a lodge, which communicated with several corridors, by apertures formed in the masonry; on another, a regularly-formed hall was constructed, the vaulted ceiling of which was sustained by numerous pillars; further off, again, might be recognised the rudiments of one of those cross roads of which I have before spoken, and in which several avenues terminate. These parts of the anthill were the most spacious; the ants, however, did not appear embarrassed in constructing the ceiling to cover them in, although they were often more than two inches in breadth.

"In the upper part of the angles formed by the different walls, they laid the first foundations of this ceiling, and from the top of each pillar, as from so many centres, a layer of earth, horizontal and slightly convex, was carried forward to meet the several portions coming from different points of the large public thoroughtare.

"I sometimes, however, laboured under an apprehension that the building could not possibly resist its own weight, and that such extensive ceilings, sustained only by a few pillars, would fall into ruin from the rain which continually dropped upon them; but I was quickly convinced of their stability, from observing that the earth, brought by these insects, adhered at all points, on the slightest contact; and that the rain, so far from lessening the cohesion of 
its particles, appeared even to increase it. Thus, instead of injuring the building, it even contributed. to render it still more secure.

" These particles of moistened earth, which are only held together by juxtaposition, require a fall of rain to cement them more closely, and thus varnish over, as it were, those places where the walls and galleries remain uncovered. All inequalities in the masonry then disappear. The upper part of these stories, formed of several pieces brought together, presents but one single layer of compact earth. They require for their complete consolidation nothing but the heat of the sun. It sometimes, however, happens that a violent rain will destroy the apartments, especially should they be but slightly arched; but under these circumstances the ants reconstruct them with wonderful patience.

" These different labours were carried on at the same time, and were so closely followed up in the different quarters, that the ant-hill received an additional story in the course of seven or eight hours. All the vaulted ceilings being formed upon a regular plan, and at equal distances from one wall to the other, constituted, when finished, but one single roof. Scarcely had the ants finished one story than they began to construct another; but they had not time to finish it-the rain ceasing before the ceiling was fully completed. 'They still, however, continued their work for a few hours, taking advantage of the humidity of the carth; but a keen north wind soon sprung up, and hastily dried the collected fragments, which, no longer possessing the same adherence, readily fell into powder. The ants, finding their efforts ineffectual, were at length discouraged, and abandoned their employment; but what was my astonishment when I saw them destroy all the apartments that were yet uncovered, scattering here and vol, IV. 
there over the last story the materials of which they had been composed! These facts incontestably prove, that they employ neither gum, nor any kind of cement, to bind together the several substances of their nest; but in place of this avail themselves of the rain, to work or knead the earth, leaving the sun and wind to dry and consolidate it."

Dr Johnson of Bristol observed very similar proceedings in the case of a colony of red ants (Myrmica rubra?), the roof of whose nest was formed by a flat stone. During dry weather, a portion of the side walls fell in; but the rubbish was quickly removed, though no repairs were attempted till a shower of rain enabled them to work. As soon as this occurred, they worked with extraordinary rapidity, and in a short time the whole of the fallen parts were rebuilt, and rendered as smooth as if polished with a trowel.

When a gardener wishes to water a plot of ground where he has sown seeds that require nice management, he dips a strong brush into water, and passes his hand backwards and forvards over the hairs for the purpose of producing a fine artificial shower. Huber successfully adopted the same method to excite his ants to recommence their labours, which had been interrupted for want of moisture. But sometimes when they deem it unadvisable to wait for rain, they dig down (as we remarked to be the practice of the mason-bees) till they arrive at earth sufficiently moist for their purpose. They do not, however, like these bees, merely dig for materials; for they use the excavations for apartments, as well as what they construct with the materials thence derived. They appear, in short, to be no less skilful in mining than in building. Such is the general outline of the operations of

* M. P. Lluber on Ants, p. 31 . 
this singular species; but we are still more interested with the history which M. P. Huber has given of the labours of a individual ant. "One rainy day," he says, "I observed a labourer of the dark ashcoloured species (Formica fusca) digging the ground near the aperture which gave entrance to the anthill. It placed in a heap the several fragments it had scraped up, and formed them into small pellets, which it deposited here and there upon the nest. It returned constantly to the same place, and appeared to have a particular design, for it laboured with ardour and perseverance. I remarked a slight furrow, excavated in the ground in a straight line, representing the plan of a path or gallery. The labourer (the whole of whose movements fell under my immediate observation) gave it greater depth and breadth, and cleared out its borders; and I saw, at length-in which I could not be deceived-that it had the intention of establishing an avenue which was to lead from one of the stories to the underground chambers. This path, which was about two or three inches in length, and formed by a single ant, was opened above, and bordered on each side by a buttress of earth. Its concavity, in the form of a pipe (gouttière), was of the most perfect regularity; for the architect had not left an atom too much. The work of this ant was so well followed and understood, that I could almost to a certainty guess its next proceeding, and the very fragment it was about to remove. At the side of the opening where this path terminated was a second opening, to which it was necessary to arrive by some road. The same ant began and finished this undertaking without assistance. It furrowed out and opened another path, parallel to the first, leaving between each a little wall of three or four lines in height."

Like the hive-bees, ants do not seem to work 
in concert, but each individual separately. There is, consequently, an occasional want of coincidence in the walls and arches; but this does not much embarrass them, for a worker, on discovering an error of this kind, seems to know how to rectify it, as appears from the following observations.

"A wall," says M. Huber, "had been erected, with the view of sustaining a vaulted ceiling, still incomplete, that had been projected towards the wall of the opposite chamber. The workman who began constructing it, had given it too little elevation to meet the opposite partition, upon which it was to rest. Harl it been continued on the original plan, it must infallibly have met the wall at about one half of its height; and this it was necessary to avoid. This state of things very forcibly claimed my attention; when one of the ants arriving at the place, and visiting the works, appeared to be struck by the difficulty which presented itself; but this it as soon obviated, by taking down the ceiling, and raising the wall upon which it reposed. It then, in my presence, constructed a new ceiling with the fragments of the former one.

"When the ants commence any undertaking, one would suppose that they worked after some preconceived idea, which, indeed, would seem verified by the execution. Thus, should any ant discover upon the nest two stalks of plants which lie crossways, a disposition favourable to the construction of a lodge, or some little beams that may be useful in forming its angles and sides, it examines the several parts with attention; then distributes, with much sagacity and address, parcels of eath in the spaces, and along the stems, taking from every quarter materials adapted to its object, sometimes not earing to destroy the work that others had commenced; so much are its motions regulated by the idea it has conceived, 
and upon which it acts, with little attention to all else around it. It goes and returns, until the plan is sufficiently understood by its companions.

"In another part of the same ant-hill," continues M. Huber, "several fragments of straw seemed expressly placed to form the roof of a large house; a workman took advantage of this disposition. These fragments lying horizontally, at half an inch distance from the ground, formed, in crossing each other, an oblong parallelogram. The industrious insect commenced by placing earth in the several angles of this frame-work, and all along the little beams of which it was composed. The same workman afterwards placed several rows of the same materials against each other, when the roof became very distinct. On perceiving the possibility of profiting by another plant to support a vertical wall, it began laying the foundations of it; other ants having by this time arrived, finished in common what this had commenced," "*

II. Huber made most of his observations upon the processes followed by ants in glazed artificial hives

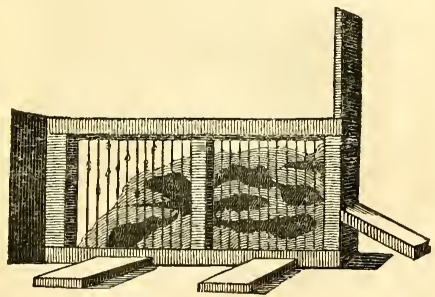

* Huber on Ants, p. 43. vol. IV. 
or formicaries. The preceding figure represents a view of one of his formicaries of mason-ants.

We have ourselves followed up his observations, both on natural ant-hills and in artificial formicaries. On digging cautiously into a natural ant-hill, established upon the edge of a garden walk, we were enabled to obtain a pretty complete view of the interior structure. There were two stories, composed of large chambers, irregularly oval, communicating with each other by arched galleries, the walls of all which were as smooth and well polished as if they had been passed over by a plasterer's trowel. The floors of the chambers, we remarked, were by no means either horizontal or level, but all more or less sloped, and exhibiting in each chamber at least two slight depressions of an irregular shape. We left the under story of this nest untouched, with the notion that the ants might repair the upper galleries, of which we had made a vertical section; but instead of doing so they migrated during the day to a large crack, formed by the dryness of the weather, about a yard from their old nest.*

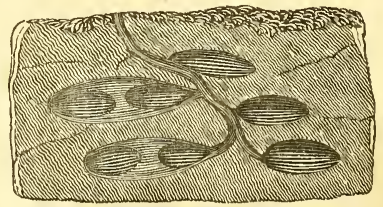

We put a number of yellow ants (Formica flava), with their eggs and cocoons, into a small glass frame, more than half full of moist sand taken from their native hill, and placed in a sloping position, in order

$$
\text { * J. R. }
$$


to see whether they would bring the nearly vertical, and therefore insecure, portion to a level by masonry. We were delighted to perceive that they immediately resolved upon performing the task which had been assigned them, though they did not proceed very methodically in their manner of building; for instead of beginning at the bottom, and building upwards, many of them went on too add to the top of the outer surface, which increased rather than diminished the security of the whole. Withal, however, they seemed to know how far to go, for no portion of the newly built wall fell; and in two days they had not only reared a pyramidal mound to prop the rest, but had constructed several galleries and chambers for lodging the cocoons, which we had scattered at random amongst the sand. The new portion of this building is represented in the figure as supporting the upper and insecure parts of the nest.

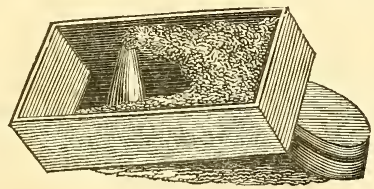

We are sorry to record that our ingenious little masons were found upon the third day strewed about the outside of the building dead or dying, either from over fatigue or perhaps fiom surfeit, as we had supplied them with as much honey as they could devour. A small colony of turf-ants have at this moment (July 28th, 1829) taken possession of the premises of their own accord.* 


\section{Chapter XV.}

Structures of the Wood-ant or Pismire, and of Carpenter-ants.

ThE largest of our British ants is that called the Hillant by Gould, the Fallow-ant by the English translator of Huber, and popularly the Pismire; but which we think may be more appropriately named the $W$ oodant (Formica rufa, LATR.) from its invariable habit of living in or near woods and forests. This insect may be readily distinguished from other ants by the dusky black colour of its head and hinder parts, and the rusty brown of its middle. The structures reared by this species are often of considerable magnitude, and bear no small resemblance fo a rook's nest thrown upon the ground, bottom upwards. They occur in abundance in the woods near London, and in many other parts of the country: in Oak of Honour wood alone, we are acquainted with the localities of at least two dozen,- - some in the interior and others on the hedge-banks on the outskirts of the wood.*

The exterior of the nest is composed of almost every transportable material which the colonists can find in their vicinity; but the greater portion consists of the stems of withered grass and short twigs of trees, piled up in apparent confusion, but with sufficient regularity to render the whole smooth, conical, and sloping towards the base, for the purpose, we may infer, of carrying off rain water. When within reach of a corn-field, they often also pick up grains of wheat, barley, or oats, and carry them to the nest 
as building materials, and not for food as was believed by the ancients. There are wonders enough observable in the economy of ants, without having recourse to fancy-wonders which made Aristotle extol the sagacity of bloodless animals, and Cicero ascribe to them not only sensation, but mind, reason, and memory.* Alian, however, describes, as if he had actually witnessed it, the ants ascending a stalk of growing corn, and throwing down " the ears which they bit off to their companions below," ( $\tau \omega$ Snew $\tau \omega x \kappa \tau \omega)$. Aldrovandus assures us that he had seen their granaries; and others pretend that they shrewdly bite off the ends of the grain to prevent it from germinating. $\uparrow$ These are fables which accurate observation has satisfactorily contradicted.

But these errors, as it frequently happens, have contributed to a more perfect knowledge of the insects than we might otherwise have obtained; for it was the wish to prove or disprove the circumstance of their storing up and feeding upon grain, which led Gould to make his observations on English ants; as the notion of insects being produced from putrid carcases had before led Redi to his ingenious experiments on their generation. Yet, although it is nore than eighty years since Gould's book was published, we find the error still repeated in very respectable publications.t

The coping which we above described as forming the exterior of the wood-ant's nest, is only a small portion of the structure, which consists of a great number of interior chambers and galleries, with funnel-shaped avenues leading to them.- The coping,

*In formic î non modo sensus, sed etiam mens, ratio, memorìa.

+ Aldrovandus de Formicis, and Jouston, 'i haumaturg. Nat. p. 356 .

$\ddagger$ See Professor Paxton's Illustr. of Scripture, i. 307. 
indeed, is one of the most essential parts, and we cannot follow a more delightful guide than the younger Huber, in detailing its formation.

"The labourers," he says, " of which the colony is composed, not only work continually on the outside of their nest, but, differing very essentially from other species, who unwillingly remain in the interior, sheltered from the sun, they prefer living in the open air, and do not hesitate to carry on, even in our presence, the greater part of their operations.

"To have an idea how the straw or stubble-roof is formed, let us take a view of the ant-hill at its origin, when it is simply a cavity in the earth. Some of its future inhabitants are seen wandering about in search of materials fit for the exterior work, with which, though rather irregularly, they cover up the entrance; whilst others are employed in mixing the earth, thrown up in hollowing the interior, with fragments of wood and leaves, which are every moment brought in by their fellow-assistants; and this gives a certain consistence to the edifice, which increases in size daily. Our little architects leave here and there cavities, where they intend constructing the galleries which are to lead to the exterior, and as they remove in the morning the barriers placed at the entrance of their nest the preceding evening, the passages are kept open during the whole time of its construction. We soon observed the roof to become convex; but we should be greatly deceived did we consider it solid. This roof is destined to include many apartments or stories. Having observed the motions of these little builders through a pane of glass, adjusted against one of their habitations, I am thence enabled to speak with some degree of certainty upon the manner in which they are constructed. I ascertained, that it is by excavating, or 
mining the under portion of their edifice, that they form their spacious halls, low indeed, and of heavy construction, yet sufficiently convenient for the use to which they are appropriated, that of receiving, at certain hours of the day, the larvæ and pupæ.

"These halls have a free communication by galleries, made in the same manner. If the materials of which the ant-hill is composed were only interlaced, they would fall into a confused beap every time the ants attempted to bring them into regular order. This, however, is obviated by their tempering the earth with rain-water, which, afterwards hardened in the sun, so completely and effectually binds together the several substances, as to permit the removal of certain fragments from the ant-hill without any injury to the rest; it, moreover, strongly opposes the introduction of the rain. I never found, even after long and violent rains, the interior of the nest wetted to more than a quarter of an inch from the surface, provided it had not been previously out of repair, or deserted by its inhabitants.

"The ants are extremely well sheltered in their chambers, the largest of which is placed nearly in the centre of the building; it is much loftier than the rest, and traversed only by the beams that support the ceiling; it is in this spot that all the galleries terminate, and this forms, for the most part, their usual residence.

"As to the underground portion, it can only be seen when the ant-hill is placed against a declivity; all the interior may be then readily brought in view, by simply raising up the straw-roof. The subterranean residence consists of a range of apartments, excavated in the earth, taking an horizontal direction."

* Huber on Ants, p. 15. 
IM. P. Huber, in order to observe the operations of the wood-ant with more attention, transferred colonies of them to his artificial formicaries, plunging the feet of the stand into water to prevent their escape till

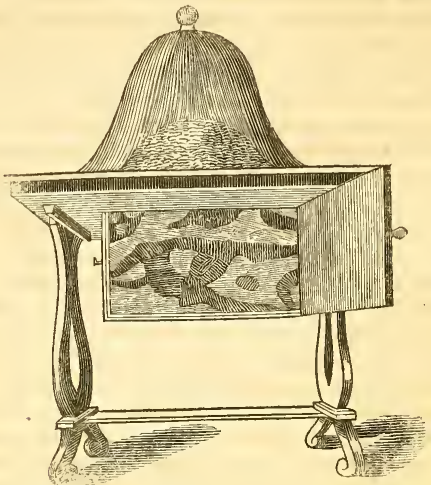

they were reconciled to their abode, and had made some progress in repairing it. The preceding is a figure of the apparatus which he used for this purpose.

There is this remarkable difference in the nest of the wood-ants, that they do not construct a long covert way as if for concealment, as the yellow and the brown ants do. The wood-ants are not, like them, afraid of being surprised by enemies, at least during the day, when the whole colony is either foraging in the vicinity or employed on the exterior. But the proceedings of the wood-ants at night are well worthy of notice; and when MI. Huber began to study 
their economy, he directed his entire attention to their night procecdings. "I remarked," says he, "that their habitations changed in appearance hourly, and that the diameter of those spacious avenues, where so many ants could freely pass each other during the day, was, as night approached, gradually lessened. The aperture, at length, totally disappeared, the dome was closed on all sides, and the ants retired to the bottom of their nest.

"In further noticing the apertures of these anthills, I fully ascertained the nature of the labour of its inhabitants, of which I could not before even guess the purport; for the surface of the nest presented such a constant scene of agitation, and so many insects were occupied in carrying materials in every direction, that the movement offered no other image than that of confusion.

"I saw then clearly that they were engaged in stopping up passages; and for this purpose they at first brought forward little pieces of wood, which they deposited near the entrance of those avenues they wished to close; they placed them in the stubble; they then went to seek other twigs and fragments of wood, which they disposed above the first, but in a different direction, and appeared to ehoose pieces of less size in proportion as the work advanced. They, at length, brought in a number of dried leaves, and other materials of an enlarged form, with which they covered the roof: an exact miniature of the art of our builders, when they form the covering of any building? Nature, indeed, seems everywhere to have anticipated the inventions of which we boast, and this is doubtless one of the most simple.

"Our little insects now in safety in their nest, retire gradually to the interior before the last passages are closed, one or two only remain without, or VOL. IV. 
concealed behind the doors on guard, whilst the rest either take their repose or engage in different occupations in the most perfect security. I was impatient to know what took place in the morning upon these ant-hills, and therefore visited them at an early hour. I found them in the same state in which I had left them the preceding evening. A few ants were wandering about on the surface of the nest, some others issued from time to time from under the margin of their little roofs formed at the entrance of the galleries: others afterwards came forth, who began removing the wooden bars that blockaded the entrance, in which they readily succeeded. This labour occupied them several hours. The passages were at length free, and the materials with which they had been closed, scattered here and there over the ant-hill. Every day, morning and evening, during the fine weather, I was a witness to similar proceedings. On days of rain the doors of all the ant-hills remained closed. When the sky was cloudy in the morning, or rain was indicated, the ants, who seemed to be aware of it, opened but in part their several avenues, and immediately closed them when the rain commenced."

The galleries and chambers which are roofed in as thus described, are very similar to those of the rnason-ants, being partly excavated in the earth, and partly built with the clay thence procured. It is in these they pass the night, and also the colder months of the winter, when they become torpid or nearly so, and of course require not the winter granaries of corn with which the ancients fabulously furnished them.

* Huber on Ants, p. 11. 


\section{Carpenter-Ants.}

The ants that work in wood perform much more extensive operations than any of the other carperiter insects which we have mentioned. Th ir only tools, like those of bees and wasps, are their jaws or mandibles; but though these may not appear so curiously constructed as the ovipositor file of the tree-hopper (Cicadce), or the rasp and saw of the saw-flies (Tenthredines), they are no less efficient in the performance of what is required. Among the carpenter-ants the emmet or jet-ant ( $F$. fuliginosa) holds the first rank, and is easily known by being rather less in size than the wood-ant, and by its fine shining black colour. It is less cornmon in Britain than some of the prececing, though its colonies may occasionally be met with in the trunks of decaying oak or willow trees in hedges.

"The labourers," says Huber, "of this species, work always in the interior of trees, and are desirous of being screened from observation; thus every hope on our part is precluded of following them in their several occupations. I tried every expedient I could devise to surmount this difficulty; I endeavoured to accustom these ants to live and work under my inspection, but all my efforts were unsuccessful; they even abandoned the most considerable portion of their nest to seek some new asylum, and spurned the honey and sugar which I offered then for nourishment. I was now, by necessity, limited to the inspection only of their edifices; but by decomposing some of the fragments with care, I hoped to acquire some knowledge of their organization.

" On one side I found horizontal galleries, hidden in great part by their walls, which follow the circular direction of the layers of the wood; and on another, parallel galleries, separated by extremely thin 
partitions, having no communication except by a few oval apertures. Such is the nature of these works, remarkable for their delicacy and lightness.

"In other fragments I found avenues which opened laterally, including portions of walls and transverse partitions, erected here and there within the galleries, so as to form separate chambers. When the work is further advanced, round holes are always observed, encased, as it were, between two pillars cut out in the same wall. These holes in course of time become square, and the pillars, originally arched at both ends, are worked into regular columns by the chisel of our sculptors. This, then, is the second specimen of their art. This portion of the edifice will probably remain in this state.

"But in another quarter are fragments differently wrought, in which these same partitions, pierced now in every part, and hewn skilfully, are transformed into colonnades, which sustain the upper stories, and leave a free communication throughout the whole extent. It can readily be conceived, how parallel galleries, hollowed out upon the same plan, and the sides taken down, leaving only from space to space what is necessary to sustain their ceilings, may form an entire story; but as each has been pierced separately, the flooring cannot be very level: this, however, the ants turn to their advantage, since these furrows are better adapted to retain the larva that may be placed there.

"The stories constructed in the great roots offer greater irregularity than those in the very body of the tree, arising either from the hardness and interlacing of the fibres, which renders the labour more difficult, and obliges the labourers to depart from their accustomed ranner, or from their not observing in the extremities of their edifice the same arrangement as in the centre; whatever it be, horizontal stories and 


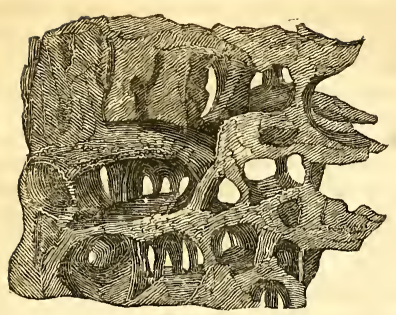

Portion of a tree, with chambers and galleries chiselled out by Jet-Ants.

numerous partitions are still found. If the work be less regular, it becomes more delicate; for the ants, profiting by the hardness and solidity of the materials give to their building an extreme degree of lightness. I have seen fragments of from eight to ten inches in length, and of equal height, formed of wood as thin as paper, containing a number of apartments, and presenting the most singular appearance. At the entrance of these apartments, worked out with so much care, are very considerable openings; but in place of chambers and extensive galleries, the layers of the wood are hewn in arcades, allowing the ants a free passage in every direction. These may be regarded as the gates or vestibules conducting to the several lodges." "*

It is a singular circumstance in the structures of these ants, that all the wood which they carve is tinged of a black colour as if it were smoked; and $\mathbf{M}$. Huber was not a little solicitous to discover whence this arose. It certainly does not add to the beauty

* Huber, p. 56.

NOL. IV. 
of their streets, which look as sombre as the most smoke-dyed walls in the older lanes of the metropolis. M. Huber could not satisfy himself whether it was caused by the exposure of the wood to the atmosphere, by some emanation from the ants, or by the thin layers of wood being acted upon or decomposed by the formic acid.* But if any or all of these causes operated in blackening the wood, we should be ready to anticipate a similar effect in the case of other species of ants which inhabit trees; yet the black tint is only found in the excavations of the jet ant.

We are acquainted with several colonies of the jet ants,-one of which, in the roots and trunk of an oak on the road from Lewisham to Sydenham, near Brockley in Kent, is so extremely populous, that the numbers of its inhabitants appeared to us beyond any reasonable estimate. None of the other colonies of this species which we have seen, appear to contain many hundreds. On cutting into the root of the before-mentioned tree, we found the vertical excavations of much larger dimensions, both in width and depth, than those represented by Huber in the preceding cut (page 281). What surprised us the most, was to see the tree growing vigorously and fresh, though its roots were chiselled in all directions by legions of workers, while every leaf, and every inch of the bark, was also crowded by parties of foragers. On one of the low branches we found a deserted nest of the white throat (Sylvia cinerea, TeMminck), in the cavity of which they werc piled upon one another as close as the unhappy negroes in the hold of a slave ship; but we could not discover what had attracted them hither. Another dense group, collected on one of the branches, led us to the discovery of a very singular oak gall, formed on the

* The acid of ants. 
bark in the shape of a pointed cone, and crowded together. It is probable that the juice which they extracted from these galls was much to their taste.*

Besides the jet-ant, several other species exercise the art of carpentry,-nay, what is more wonderful still, they have the ingenuity to knead up, with spiders' web for a cement, the chips which they chisel out into a material with which they construct entire chambers. The species which exercise this singular art are the Ethiopian (Formica nigra) and the yellow ant $(\boldsymbol{F}$. flava). $\dagger$

We once observed the dusky ants ( $\boldsymbol{F}$. fusca), at Blackheath in Kent, busily employed in carrying out chips from the interior of a decaying black poplar, at the root of which a colony was established; but, though it thence appears that this species can chisel wood if they choose, yet they usually burrow in the earth, and by preference, as we have remarked, at the root of a tree, the leaves of which supply them with food.

Among the foreign ants, we may mention a small yellow ant of South America, described by Dampier, which seems, from his account, to construct a nest of green leaves. "Their sting," he says, " is like a spark of fire; and they are so thick among the boughs in some places, that one shall be covered with them before he is aware. These creatures have nests on great trees, placed on the body between the limbs: some of their nests are as big as a hogshead. This is their winter habitation; for in the wet season they all repair to these their eities, where they preserve their eggs. In the dry season, when they leave their nests, they swarm all over the woodlands, for they never trouble the savannahs. Great paths, three or

$$
\text { * J. R. }
$$

t Huber. 
four inches broad made by them, may be seen in the woods. They go out light, but bring home heavy loads on their backs, all of the same substance, and equal in size. I never observed any thing besides pieces of green leaves, so big that I could scarcely sce the insect for his burden; yet they would march stoutly, and so many were pressing forward that it was a very pretty sight, for the path looked perfectly green with them."

Ants observed in New South Wales, by the gentlemen in the expedition under Captain Cook, are still more interesting. "Some," we are told, " are as green as a leaf, and live upon trees, where they build their nests of various sizes, between that of a man's head and his fist. These nests are of a very curious structure: they are formed by bending down several of the leaves, each of which is as broad as a man's hand, and glueing the points of them together, so as to form a purse. The viseous matter used for this purpose is an animal juice which nature has enabled them to elaborate. Their method of first bending down the leaves we had no opportunity to observe; but we saw thousands uniting all their strength to bold them in this position, while other busy multitudes were employed within, in applying this gluten that was to prevent their returning back. To satisfy ourselves that the leaves were bent and held down by the efforts of these diminutive artificers, we disturbed them in their work; and as soon as they were driven from their stations, the leaves on which they were employed sprang up with a force much greater than we could have thought them able to conquer by any combination of their strength. But, though we gratified our euriosity at their expense, the injury did not go unrevenged; for thousands immediately threw themselves upon us, and gave us intolerable pain with their stings, especially those which took possession 
of our necks and hair, from whence they were not easily driven. Their sting was scarcely less painful than that of a bee; but, except it was repeated, the pain did not last more than a minute.

"Another sort are quite black, and their operation, and manner of life are not less extraordinary. Their habitations are the inside of the branches of a tree which they contrive to excavate, by working out the pith almost to the extremity of the slenderest twig, the tree at the same time flourishing as if it had no such inmate. When we first found the tree, we gathered some of the branches; and were scarcely less astonished than we should have been to find that we had profaned a consecrated grove, where every tree, upon being wounded, gave signs of life; for we were instantly covered with legions of these animals, swarming from every broken bough, and inflicting their stings with incessant violence.

"A third kind we found nested in the root of a plant, which grows on the bark of trees in the manner of mistletoe, and which they had perforated for that use. This root is commonly as big as a large turnip, and sometimes much bigger. When we cut it, we found it intersected by innumerable winding passages, all filled with these animals, by which, however, the vegetation of the plant did not appear to have suffered any injury. We never cut one of these roots that was not inhabited, though some were not bigger than a hazel-nut. The animals themselves are very small, not niore than half as big as the common red ant in England. They had stings, but scarcely force enough to malie them felt: they had, however, a power of tormenting us in an equal, if not in a greater degree; for the moment we handled the root, they swarmed from innumerable holes, and running about those parts of the body that were un- 
covered, produced a titillation more intolerable than pain, except it is increased to great violence."

The species called sugar-ants in the West Indies are particularly destructive to the sugar cane, as well to lime, lemon, and orange-trees, by excavating their nests at the roots, and so loosening the earth that they are frequently uprooted and blown down by the winds. If this does not happen, the roots are deprived of due nourishment, and the plants become sickly and die. $\dagger$

* Hawkesworth's Account of Cook's First Voyage.

† Phil. Trans., xxx., p. 346. 


\section{Chapter XVI.}

Structures of White ants, or Termites.

WHEN we look back upon the details which we have given of the industry and ingenuity of numerous tribes of insects, both solitary and social, we are induced to think it almost impossible that they could be surpassed. The structures of wasps and bees, and still more those of the wood-ant (Formica rufa), when placed in comparison with the size of the insects, equal our largest cities compared with the stature of man. But when we look at the buildings erected by the white ants of tropical climates, all that we have been surveying dwindles into insignificance. Their industry appears greatly to surpass that of our ants and bees, and they are certainly more skilful in architectural contrivances. The elevation, also, of their edifices is more than five hundred times the height of the builders. Were our houses built according to the same proportions, they would be twelve or fifteen times higher than the London Monument, and four or five time higher than the pyramids of Egypt, with corresponding dimensions in the basements of the edifices. These statements are, perhaps, necessary to impress the extraordinary labours of ants upon the mind; for we are all more or less sensible to the force of comparisons. The analogies between the works of insects and of men are not perfect; for insects are all provided with instruments, peculiarly adapted to the end which they instinctively seek, while man has to form a plan by progressive thought 
and upon the experience of others, and to complete it with tools which he also invents.

The termites do not stand above a quarter of an inch high, while their nests are frequently twelve feet; and Jobson mentions some which he had seen as high as twenty feet; "of compasse," he adds, " to contayne a dozen men, with the heat of the sun baked into that hardnesse, that we used to hide curselves in the ragged toppes of them when we took up stands to shoot at deere or wild beasts." B* Bishop Heber saw a number of these high ant-hills in India, near the principal entrance of the Sooty or Moorshedabad river. "Many of them," he says, "were five or six feet high, and probably seven or eight feet in circumference at the base, partially overgrown with grass and ivy, and looking at a distance like the stumps of decayed trees. I think it is Ctesias, among the Greek writers, who gives an account, alluded to by Lucian, in his ' Cock,' of monstrous ants in India, as large as foxes. The falsehood probably originated in the stupendous fabrics which they rear here, and which certainly might be supposed to be the work of a much larger animal than their real architect." $\dagger$ Herodotus has a similar fable of the enormous size and brilliant appearance of the ants of India.

Nor is it only in constructing dwellings for themselves that the termites of Africa and of other hot climates employ their masonic skill. Though, like our ants and wasps, they are almost omnivorous, yet wood, particularly when felled and dry, seems their favourite article of food; but they have an utter aversion to feeding in the light, and always eat their way with all expedition into the interior. It thence would seem necessary for them either to leave the bark of a tree, or the outer portion of the beam or door

* Jobson's Gambia, in Purchas's Pilgrims, ii., p. 1570.

† Heber's Journal, vol. i., p. 248. 
of a house, undevoured, or to eat in open day. They do neither; but are at the trouble of constructing galleries of clay, in which they can conceal themselves, and feed in security. In all their foraging excursions, indeed, they build covert ways, by which they can go out and return to their encampment.*

Others of the species (for there are several) instead of building galleries, exercise the art of miners, and make their approaches under ground, penetrating beneath the foundation of houses or areas, and rising again, either through the floors, or by entering the bottom of the posts that support the building, when they follow the course of the fibres, and make their way to the top, boring holes and cavities in different places, as they proceed. Multitudes enter the roof, and intersect it with pipes or galleries, formed of wet clay; which serve for passages in all directions, and enable them more readily to fix their habitations in it. They prefer the softer woods, such as pine and fir, which they hollow out with such nicety, that they leave the surface whole, after having eaten away the inside. A shelf or plank attacked in this manner, looks solid to the eye, when, if weighed, it will not out-balance two sheets of pasteboard of the same dimensions. It sometimes happens, that they carry this operation so far on stakes in the open air, as to render the bark too flexible for their purpose; when they remedy the defect by plastering the whole stick with a sort of mortar which they make with clay; so that, on being struck, the form vanishes, and the artificial covering falls in fragments on the ground. In the woods, when a large tree falls from age or accident, they enter it on the side next the ground, and devour at leisure, till little more than the bark

* Smeathman, in Phil. 'Trans., vol. $1 \times x i$.

vol. IV. 
is left. But in this case they take no precaution of strengthening the outward defence, but leave it is such a state as to deceive an eye unaccustomed to see trees thus gutted of their insides; and "you may as well," says Mr Smeathman, "step upon a cloud." It is an extraordinary fact, that when these creatures have formed pipes in the roof of a house, instinct directs them to prevent its fall, which would ensue from their having sapped the posts on which it rests; but, as they gnaw away the wood, they fill up the interstices with clay, tempered to a surprising degree of hardness; so that, when the house is pulled down, these posts are transformed from wood to stone. They make the walls of their galleries of the same composition as their nests, varying the materials according to their kind: one species using red clay, another black clay, and a third a woody substance, cemented with gums, as a security from the attacks of their enemies, particularly the common ant, which, being defended by a strong, hcrny shell, is more than a match for them; and when it can get at them, rapaciously seizes them, and drags them to its nest for food for its young brood. If any accident breaks down part of their walls, they repair the breach with all speed. Instinct guides them to perform their office in the creation, by mostly confining their attacks to trees that are beginning to decay, or such timber as has been severed from its root for use, and would decay in time. Vigorous;, healthy trees do not require to be destroyed, and, accordingly, these consumers have no taste for them.*

M. Adanson describes the termites of Senegal as constructing covert ways along the surface of wood whidh they intend to attack; but though we have no

* Emeathmar. 
reason to distrust so excellent a naturalist, in describing what he saw, it is certain that they more commonly eat their way into the interior of the wood, and afterwards form the galleries, when they find that they have destroyed the wood till it will no longer afford them protection.

But it is time that we slould come to their principal building, which may, with some propriety, be called a city; and, according to the method we have followed in other instances, we shall trace their labours from the commencement. We shall begin with the operations of the species which may be appropriately termed the Warrior (Termes fatalis, Linn.; $\boldsymbol{T}$. Bellicosus, Sмeath.).

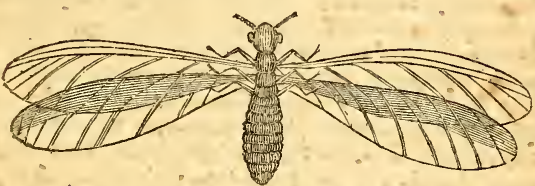

Termes bellicosus in the winged state.

We must premise, that though they have been termed white ants, they do not belong to the same order of insects with our ants; yet they have a slight resemblance to ants in their form, but more in their economy. Smeathman, to whom we owe our chief knowledge of the genus, describes them as consisting of kings, queens, soldiers, and workers, and is of opinion, that the workers are larvio, the soldiers nymphr, and the lings and queens the perfect insects. In this opinion, he coincides with Sparrmann* and others; but Latreille is inclined

* Quoted by de Geer, vol. vii. 
to think, from what he observed in a European species, (Turmes lucifugus,) found near Bordeaux, that the soldiers form a distinct race, like the neutre workers among bees and ants; while the working termites are larvæ,* which are furnished with strong mandibles for gnawing; when they become nymphs, the rudiments of four wings appear, which are fully developed in the perfect insects. In this state, they migrate to form new colonies, but the greater number of them perish in a few hours, or become the prey of birds, and even the natives, who fry them as delicacies. "I have discoursed with several gentlemen," says Smeathman, " upon the taste of the white ants, and on comparing notes, we have always agreed that they are most delicious and delicate eating. One gentleman compared them to sugared marrow, another to sugared cream and a paste of sweet almonds." +

Mr Smeathman's very interesting paper affords us the most authentic materials for the further description of these wonderful insects; and we therefore continue partly to extract from, and partly to abridge, his account.

The few pairs that are so fortunate as to survive the various casualties that assail them, are usually found by workers (larvæ) which, at this season, are running continually on the surface of the ground, on the watch for them. As soon as they discover the objects of their search, they begin to protect them from their surrounding enemies, by enclosing them in a small chamber of clay, where they become the parents of a new community; and are distinguished from the other inhabitants of the nest, by the title of king and queen. Instinct directs the attention of these labouring insects to the preservation of their race, in the protection of this

* Hist. Nat. Gené rale, vol. xiii. p. 66.

† Smeathman in Phil Trans. vol. Ixxi. p. 169, note. 
pair and their offspring. The chamber that forms the rudiment of a new nest, is contrived for their safety, but the entrances to it are too small to admit of their ever lcaving it; consequently, the chargc of the eggs devolves upon the labourers, who construct nurseries for their reception. These are small, irregularly-shaped chambers, placed at first round the apartment of the king and queen, and not exceeding the size of a hazel-nut; but, in nests of long standing, they are of great comparative magnitude, and distributed at a greater distance. The receptacles for hatching the young are all composed of wooden materials, apparently joined together with gum, and, by way of defence, cased with clay. The chamber that contains the king and qucen, is nearly on a level with the surface of the ground; and as the other apartments are formed about it, it is gencrally situated at an equal distance from the sides of the nest, and directly beneath its conical point. Those apartments which consist of nurseries and magazines of provisions, form an intricate labyrinth, being separated by small, empty chambers and galleries, which surround them, or afford a communication from one to another. This labyrinth extends on all sides to the outward shells, and reaches up within it to twothirds or more of its height, leaving an open area above, in the middle, under the dome, which reminds the spectator of the nave of an old cathedral. Around this are raised three or four large arches, which are sometimes two or three feet high, next the front of the area, but diminish as they recede further back, and are lost amidst the innumerable chambers and nurseries behind them.

Every one of these buildings consists of two distinct parts, the exterior and the interior. The exterior is one large shell, in the manner of a dome, large and strong enough to inclose and shelter the interior from

VOL. IV. 
the vicissitudes of the weather, and the inhabitan! from the attacks of natural or accidental enemies. It is always, therefore, much stronger than the interior building, which is the habitable part, divided, with a wonderful kind of regularity and contrivance, into an amazing number of apartments for the residence of the king and queen, and the nursing of the numerous progeny; or for magazines, which are always found well filled with stores and provisions. The hills make their first appearance above ground by a little turret or two, in the shape of sugar-loaves, which are run a foot high, or more. Soon after, at some little distance, while the former are increasing in height and size, they raise others, and so go on increasing their number, and widening them at the base, till their works below are covered with these turrets, of which they always raise the highest and largest in the middle, and, by filling up the intervals between each turret, collect them into one dome. They are not very curious or exact in the workmanship, except in making them very solid and strong; and when, by their joining them, the dome is completed, for which purpose the turrets answer as scaffolds, they take away the middle ones entirely, except the tops, which, joined together, make the crown of the cupola, and apply the clay to the building of the works within, or to erecting fresh turrets for the purpose of raising the hillock still higher; so that some part of the clay is probably used several times, like the boards and posts of a mason's scaffolds.

When these hills are little more than half their height, it is always the practice of the wild bulls to stand as sentinels on them, while the rest of the herd are ruminating below. They are sufficiently strong for that purpose; and, at their full height, answer excellently well as places of look out; and $\mathrm{Mr}$ Smeathman has been, with four more, on the top of one of these hillocks, to watch for a vesscl in 
sight. The outward shell, or dome, is not only of use to protect and support the interior buildings from external violence and the heavy rains, but to collect and preserve a regular degree of the warmth and moisture necessary for hatching the eggs and cherishing the young. The royal chamber occupied by the king and queen, appears to be, in the opinion of this little people, of the most consequence, being alway situated as near the centre of the interior building as possible. It is always nearly in the shape of half an egg, or an obtuse oval, within, and may be supposed to represent a long oven. In the infant state of the colony, it is but about an inch in length; but in time will be increased to six or eight inches, or more, in the clear, being always in proportion to the size of the queen, who, increasing in bulk as in age, at length requires a chamber of such dimensions.

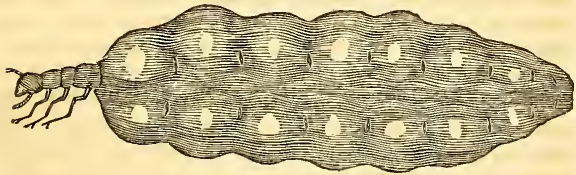

Queen distended with eggs.

Its floor is perfectly horizontal, and, in large hillocks, sometimes more than an inch thick of solid clay. The roof also, which is one solid and wellturned oval arch, is generally of about the same solidity, but in some places it is not a quarter of an inch thick, on the sides where it joins the floor, and where the doors or entrances are made level with it, at nearly equal distances from each other. These entrances will not admit any animal larger than the soldiers or labourers; so that the king and the queen 
(who is, at full size, a thousand times the weight of a king) can never possibly go out, but remain close prisoners.

The royal chamber, if in a large hillock, is surrounded by a countless number of others, of different sizes, shapes, and dimensions; but all of them arched in one way or another-sometimes elliptical or oval. These either open into each other, or communicate by passages as wide, and are evidently made for the soldiers and attendants, of whom great numbers are necessary, and always in waiting. These apartments are joined by the magazines and nurseries. The former are chambers of clay, and are always well filled with provisions, which, to the naked eye, seems to consist of the raspings of wood, and plants which the termites destroy; but are found by the microscope to be principally the gums or inspissated juices of plants. These are thrown together in little masses, some of which are finer than others, and resemble the sugar about preserved fruits; others are like tears of gum, one quite transparent, another like amber, a third brown, and a fourth quite opaque, as we see often in parcels of ordinary gums. These magazines are intermixed with the nurseries, which are buildings totally different from the rest of the apartments; for these are composed entirely of wooden materials, seemingly joined together with gums. Mr Sneathman calls tliem the nurseries, because they are invariably occupicd by the eggs and young ones, which appear at first in the shape of labourers, but white as snow. These buildings are exceedingly compact, and divided into many very small and irregular-shaped chambers, not one of which is to be found of half an inch in width. They are placed all round, and as near as possible to the royal apartments.

When the nest is in the infant state, the nurseries are close to the royal ehambers; but as, in process 
of time, the queen enlarges, it is necessary to enlarge the chamber for her accommodation; and as she then lays a greater number of eggs, and requires a greater number of attendants, so it is necessary to enlarge and increase the number of the adjacent apartments; for which purpose the small nurseries which are first built are taken to pieces, rebuilt a little further of a size larger, and the number of them increased at the same time. Thus they continually enlarge their apartments, pull down, repair, or rebuild, according to their wants, with a degree of sagacity, regularity, and foresight, not even imitated by any other kind of animals or insects.

All these chambers, and the passages leading to and from them, being arched, they help to support each other; and while the interior large arches prevent them from falling into the centre, and keep the area open, the exterior building supports them on the outside. There are, comparatively speaking, few openings into the great area, and they, for the most part, seem intended only to admit into the nurseries that genial warmth which the dome collects. The interior building, or assemblage of nurseries, chambers, \&c., has a flattish top or roof, without any perforation, which would keep the apartments below dry, in case through accident the dome should receive any injury, and let in water; and it is never exactly flat and uniform, because the insects are always adding to it by building more chambers and nurseries; so that the division or columns between the future arched apartments, resemble the pinnacles on the fronts of some old buildings, and demand particular notice, as affording one proof that for the most part the insects project their arches, and do not make them by excavation. The area has also a flattish floor, which lies over the royal chamber, but sometimes a good height above it, having nurseries and magazines 
between. It is likewise waterproof, and contrived to let the water off if it should get in and run over by some short way into the subterraneous passages, which run under the lowest apartments in the hill in various directions, and are of an astonishing size, being wider than the bore of a great cannon. One that Mr Smeathman measured was perfectly cylindrical, and thirteen inches in diameter. These subterraneous passages, or galleries, are lined very thick with the same kind of clay of which the hill is composed, and ascend the inside of the outward shell in a spiral manner; and winding round the whole building up to the top, intersect each other at different heights, opening either immediately in the dome in various places, and into the interior building, the new tarrets, \&c., or communicating with them by other galleries of different diameters, either circular or oval.

From every part of these large galleries are various small covert ways, or galleries leading to different parts of the building. Under ground there are a great many that lead downward by sloping descents, three and four feet perpendicular among the gravel, whence the workers cull the finer parts, which, being kneaded up in their mouths to the consistence of mortar, becomes that solid clay or stone of which their hills and all their buildings, except their nurseries, are composed. Other galleries again ascend, and lead out horizontally on every side, and are carried under ground near to the surface a vast distance: for if all the nests are destroyed within a hundred yards of a house, the inhabitants. of those which are left unmolested farther off, will still carry on their subterraneous galleries, and, invading it by sap and mine, do great mischief to the goods and merchandizes contained in it.

It seems there is a degree of necessity for the gal- 
leries under the hills being thus large, since they are the great thoroughfares for all the labourers and soldiers going forth or returning, whether fetching clay, wood, water, or provisions; and they are certainly well calculated for the purposes to which they are applied by the spiral slope which is given them; for if they were perpendicular, the labourers would not be able to carry on their building with so much facility, as they ascend a perpendicular with great difficulty, and the soldiers can scarcely do it at all. It is on this account that sometimes a road like a ledge is made on the perpendicular side of any part of the building within their hill, which is flat on the upper surface, and half an inch wide, and ascends gradually like a staircase, or like those winding roads which are cut on the sides of hills and mountains, that would otherwise he inaccessible; by which and similar contrivances they travel with great facility to every interior part.

This, too, is probably the cause of their building a kind of bridge of one great arch, which answers the purpose of a flight of stairs from the floor of the area to some opening on the side of one of the columns that support the great arches. This contrivance must shorten the distance exceedingly to those labourers who have the eggs to carry from the royal chamber to some of the upper nurseries, which in some hills would be four or five feet in the straightest line, and much more if carried through all the winding passages leading through the inner chambers and apartments. Mr Smeathman found one of these bridges, half an inch broad, a quarter of an inch thick, and ten inches long, making the side of an elliptic arch of proportionable size; so that it is wonderful it did not fall over or break by its own weight before they got it joined to the side of the colum above. 
It was strengthened by a small arch at the bottom, and had a hollow or groove all the length of the upper surface, either made purposely for the inha-

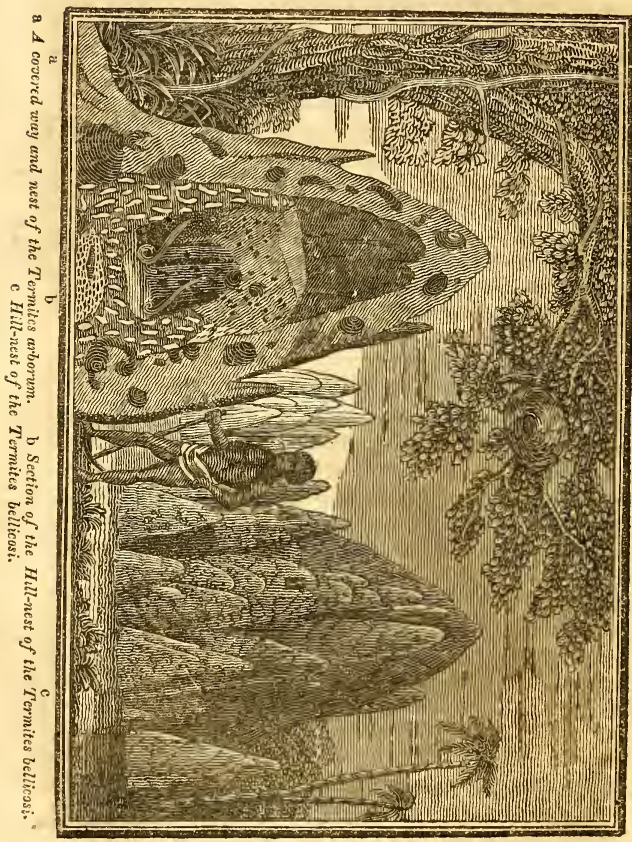


bitants to travel over with more safety, or else, which is not improbable, worn by frequent treading.

\section{Turret-Bullding White Ants.}

Apparently more than one species, smaller than the preceding, such as the Termes mordax and $T$. atrox of Smeathman, construct nests of a very different form, the figures of which resemble a pillar, with a large mushroom for a capital. These turrets are composed of well-tempered black earth, and stand nearly three feet high. The conical mushroom-shaped roof is composed of the same material, and the brims hang over the column, being three of four inches wider than its perpendicular sides. Most of them, says Smeathman, resemble in shape the body of a round windmill, but some of the roofs have little elevation in the middle. When one of these turrets is completed, the insects do not afterwards enlarge or alter it; but if it be found too small

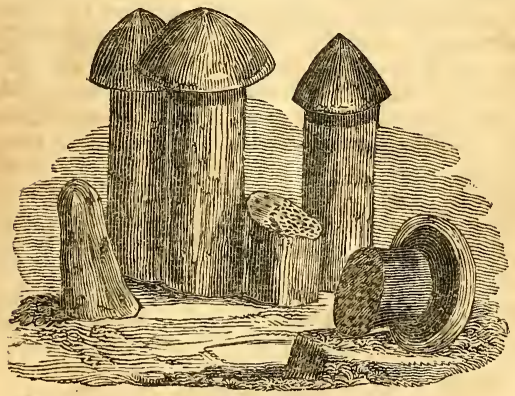

Turret Nests of White Ants. Cine Nest is represented cut through, with the $u_{2} ;$ er part lying on the ground.

VOL. IV. 20 
for them, they lay the foundation of another at a few inches distance. They sometimes, but not often, be-gin the second before the first is finished, and a third before they have completed the second. Five or six of these singular turrets in a group may be seen in the thick woods at the foot of a tree. They are so very strongly built, that in case of violence, they will sooner tear up the gravel and solid heart of their foundation than break in the middle. When any of them happen to be thus thrown down, the insects do not abandon them; but, using their overturned column, as a basis, they run up another perpendicularly from it, to the usual height, fastening the under part at the same time to the ground, to render it the more secure.

The interior of a turret is pretty equally divided into innumerable cells, irregular in shape, but usually more or less angular, generally quadrangular or pentagonal, though the angles are not well defined. Each shell has at least two entrances; but there are no galleries, arches, nor wooden nurseries, as in the nests of the Warrior ( $\boldsymbol{T}$. bellicosus). The two species which build turret nests are very different in size, and the dimensions of the nests differ in proportion.

\section{The White Ants of Trees.}

Latreille's species of white ant (Termes lucifugus, Rossi), formerly mentioned as found in the south of Europe, appear to have more the habits of the jet ant, described page 279, than their congeners of the tropics. They live in the interior of the trunks of trees, the wood of which they eat, and form their habitations of the galleries which they thus excavate. M. Latreille says they appear to be furnished with an acid for the purpose of sottening the wood, the odour of which is exceedingly pungent. They prefor the 
part of the wood nearest to the bark, which they are careful not to injure, as it affords them protection. All the walls of their galleries are moistened with small globules of a gelatinous substance, similar to gum Arabic. They are chiefly to be found in the trunks of oak and pine trees, and are very numerous.*

Another of the species (Termes arborum), described by Smeathman, builds a nest on the exterior of trees, altogether different from any of the preceding. These are of a spherical or oval shape, occupying the arm or branch of a tree sometimes from seventy to eighty feet from the ground, and as large, in a few instances, as a sugar-cask. The composition used for a building material is apparently similar to that used by the warriors for constructing their nurseries, being the gnawings of wood in very small particles, kneaded into a paste with sorne species of cement or glue, procured, as Smeathman supposes, partly from gummiferous trees, and partly from themselves; but it is more probable, we think, that it is wholly secreted, like the wax of bees, by the insects themselves. With this cement, whatever may be its composition, they construct their cells, in which there is nothing very wonderful except their great numbers. They are very firmly built, and so strongly attached to the trees, that they will resist the most violent tornado. It is impossible, indeed, to detach them, except by cutting them in pieces, or sawing off the branch, which is frequently done to procure the insects for young turkeys. (See engraving, p. 300, for a figure of this nest.)

This species very often, instead of selecting the bough of a tree, builds in the roof or wall of a house, and unless observed in time and expelled, occasions considerable damage. It is easier, in fact, to shut

* Latreille, Hist. Nat. Gén ${ }^{\circ}$ rale, tom. xiii. p. 64. 
one's door against a fox or a thief, than to exclude such insidious enemies, whose aversion to light renders it difficult to trace them even when they are numerous,

If we reflect on the prodigious numbers of those insects, and their power and rapidity of destroying, we cannot but admire the wisdom of Providence in creating so indefatigable and useful an agent in countrics where the decay of vegetable substances is rapid in proportion to the heat of the climate. We have already remarked that they always prefer decaying or dead timber; and it is indeed a very general law among insects which feed on wood to prefer what is unsound: the same principle holds with respect to fungi, lichens, and other parasitical plants.

All the species of Termites are not social; but the solitary ones do not, like their congeners, distinguish themselves in architecture. In other respects, their habits are more similar; for they destroy almost every substance, animal and vegetable. The most common of the solitary species must be familiar to all our readers by the name of wood-louse (Termes pulsatorium, LivN.; Atropos lignarius, LEACH)-one of the insects which produces the ticking, superstitiously termed the death-watch. It is not so large as the common louse, but whiter and more slender, having a red mouth and yellow eyes. It lives in old books, the paper on walls, collections of insects and dried plants, and is extremely agile in its movements, darting, by jerks, into dark corners for the purpose of concealment. It does not like to run straight forward, without resting every half-second, as if to listen or look about for its pursuer, and at such resting times it is easily taken. The ticking noise is made by the insect beating against the wood with its head, and it is supposed by some to be peculiar to the female, and to be connected with the laying of her eggs. 
M. Latreille, however, thinks that the wood-louse is only the grub of the Psocus abdominalis, in which case it could not lay eggs; but this opinion is somewhat questionable. Another death-watch is a small beetle (Anobium tesselatum).

VOL. $1 \mathrm{~V}$. 


\section{Chafter XVII.}

Structures of Silk spun by Caterpillars, including the Silk-Worms.

"Millions of spinning worms,

That in their green shops weave the smooth-hair'd silk."

Milton's Comus.

AlL the caterpillars of butterflies, moths, and, in general, of insects with four wings, are capable of spinning silk, of various degrees of fineness and strength, and differing in colour, but usually white, yellow, brown, black, or grey. This is not only of advantage in constructing nests for themselves, and particularly for their pupæ, as we have so frequently exemplified in the preceding pages, but it enables them, the instant they are excluded from the egg, to protect themselves from innumerable accidents, as well as from enemies. If a caterpillar, for instance, be exposed to a gust of wind, and blown off from its native tree, it lets itself gently down, and breaks its fall, by immediately spinning a cable of silk, along which, also, it can reascend to its former station when the danger is over. In the same way, it frequently disappoints a bird that has marked it out for prey, by dropping hurriedly down from a branch, suspended to its never-failing delicate cord. The leafrollers, formerly described, have the advantage of other catcrpillars in such cases, by being able to move as quickly backwards as forwards; so that when a bird put in its bill at one end of the roll, the insect makes a ready exit at the other, and drops along its thread as low as it judges convenient. We 
have seen caterpillars drop in this way from one to six feet or more; and by means of their cable, which they are careful not to break, they climb back with great expedition to their former place.

The structure of their legs is well adapted for climbing up their singular rope-the six fore-legs being furnished with a curved claw; while the prolegs (as they have been termed) are no less fitted for holding them firm to the branch when they have regained it, being constructed on the principle of forming a vacuum, like the leather sucker with which boys lift and drag stones. The foot of the common fly has a similar sucker, by which it is enabled to walk on glass, and otherwise support itself against gravity. The different forms of the leg and pro-leg of a spinning caterpillar are represented in the figure.
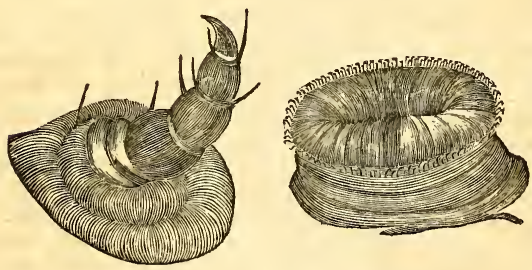

Leg and Pro-leg of a caterpillar, greatly magnified.

In order to understand the nature of the apparatus by which a caterpillar spins its silk, it is to be recollected that its whole interior structure differs from that of warm-blooded animals. It has, properly speaking, no heart, though a long tubular dorsal vessel, which runs along the back, and pulsates from twenty to one hundred times per minute, 
has been called so by Malphigi and others: but neither Lyonnet nor Cuvier could detect any vessel issuing from it; and consequently the fluid which is analogous to blood has no circulation. It differs also from the higher orders of animals, in having no brain, the nerves running along the body being only united by little knobs, called ganglions. Another circurnstance is, that it has no lungs, and does not breathe by the mouth, but by air-holes, or spiracles, eighteen in number, situated along the sides, in the middle of the rings as may be seen in the following figure from Lyonnet:

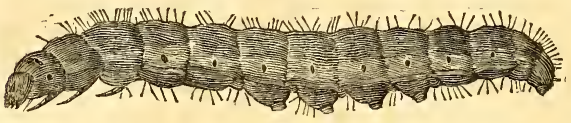

Caterpillar of the Goat-Moth (Cossus ligniperda.)

These spiracles communicate on each side with tubes, that have been called the wind-pipes (trachea ). The spinning apparatus is placed near the mouth, and is connected with the silk-bags, which are long, slender, floating vessels, containing a liquid gum. The bags are closed at their lower extreraity, become wider towards the middle, and more slender towards the head, where they unite to form the spinning-tube, or spinneret. The bags being in most cases longer than the body of the caterpillar, necessarily lie in a convoluted state, like the intestines of quadrupeds. The capacity, or rather the length, of the silk-bags, is in proportion to the quantity of silk required for spinning; the Cossus ligniperda, for example, from living in the wood of trees, spins little, having a bag only one-fourth the length of that of the silk-worm, though the caterpillar is at least twice the dimensions of the latter. The following figure taken from the 


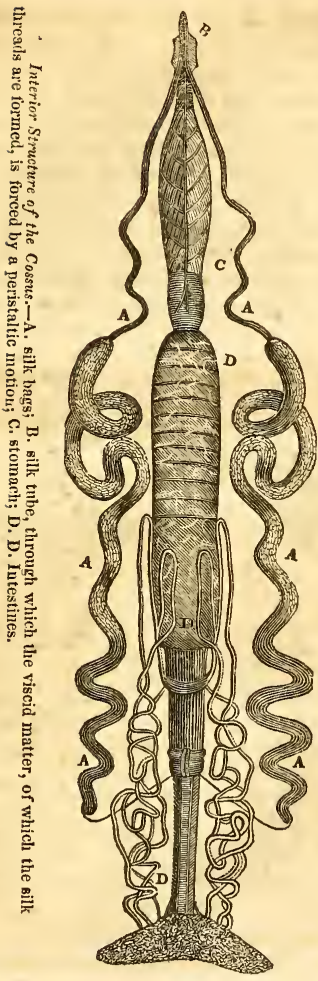


admirable treatise of Lyonnet on the anatomy of the Cossus, will render these several organs more easily understood than any description.

The spinneret itself was supposed by Réaumur to have two outlets for the silk; but Lyonnet, upon minute dissection, found that the two tubes united into one before their termination; and he also almost assured himself that it was composed of alternate slips of horny and membranaceous substance,- - the one for pressing the thread into a small diameter, and the other for enlarging it at the insect's pleasure. It is cut at the end somewhat like a writing-pen, though with less of a slope, and is admirably fitted for being applied to objects to which it may be required to attach silk. The following are magnified figures of the spinneret of the Cossus from Lyonnet.
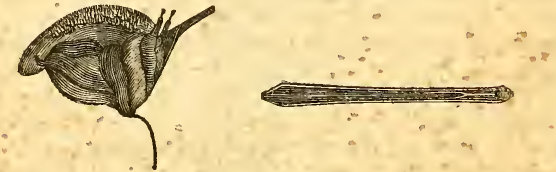

Side riew of the Silk-tube. Section of the Silk-tube, magnified 22,000 times.

"You may sometimes have seen," says the Abbé de la Pluche, "in the work-rooms of goldsmiths or gold wire-drawers, certain iron plates, pierced with holes of different calibres, through which they draw. gold and silver wire, in order to render it finer. The silk-worm has under her mouth such a kind of instrument, perforated with a pair of holes [united into one on the outside], through which she draws two drops of the gum that fills her two bags. These instruments

* Lyonnet. 


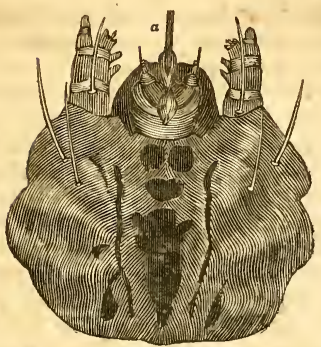

Labium or lozocr lip of Ccssus,-a. Silk-tube.

are like a pair of distaffs for spinning the gum into a silken thread. She fixes the first drop of gum that issues where she pleases, and then draws back her head, or lets herself fall, while the gum continuing to flow, is drawn out and lengthened into a double stream. Upon being exposed to the air, it immediately loses its fluidity, becomes dry, and acquires consistence and strength. She is never deceived in adjusting the dimensions of the [united] apertures, or in calculating the proper thickness of the thread, but invariably makes the strength of it proportionable to the weight of her body.

"It would be a very curious thing to know how" the gum which composes the silk is separated and drawn off from the other juices that nouish the animal. It must be accomplished like the secretions formed by glands in the human body. I am therefore persuaded that the gum-bags of the silkworm are furnished with a set of ininute glands, which, being impregnated with gum, afford a free passage to all the juices of the mulberry-leaf corres- 
ponding with this glutinous matter, while they exclude every fluid of a different quality." $*$ When confined in an open glass vessel, the goat-moth caterpillar will effect its escape, by constructing a curious silken ladder as represented by Roesel.

Caterpillars, as they increase in size, cast their skins as lobsters do their shells, and emerge into renewed activity under an enlarged covering. Previous to this change, when the skin begins to gird and pinch them, they may be observed to become languid, and indifferent to their food, and at length they cease to eat, and await the sloughing of their skin. It is now that the faculty of spinning silk secms to be of great advantage to them; for being rendered inactive and helpless by the tightening of the old skin around their expanding body, they might be swept away by the first puff of wind, and made prey of by ground beetles or other carniverous prowlers. To guard against such accidents, as soon as they feel that they can swallow no more food from being half choked by the old skin, they take care to secure themselves from danger by moorings of silk spun upon the leaf or the branch where they may be reposing. 'The caterpillar of the white satin-moth (Leucomas salicis, Stephers) in this way draws together with silk one or two leaves, similar to the leafrollers (Torlricida), though it always feeds openly without any covering. 'The caterpillar of the pussmoth again, which, in its third skin, is large and heavy, spins a thick web on the upper surface of a leaf, to which it adheres till the change is effected.

The most important operation, however of silkspinning is performed before the caterpillar is transformed into a chrysalis, and is most remarkable in the catcrpillars of moths and other four-winged flies,

* Spectacle de la Nature, vol. i. 
with the exception of those of butterflies; for though these exhibit, perhaps, greater ingenuity, they seldom spin more than a few threads to secure the chrysalis from falling, whereas the others spin for it a complete envelope or shroud. WVe have already seen, in the preceding pages, several striking instances of this operation, when probably for the purpose of husbanding a scanty supply of silk, extraneous substances are worked into the texture. In the case of other caterpillars, silk is the only material employed. Of this the cocoon of the silk-worm is the most prominent example, in consequence of its importance in our manufactures and commerce, and on that account will demand from us somewhat minute details, though it would require volumes to incorporate all the information which has been published on the subject.

\section{Sili-Worm.}

The silk-worm, like most other caterpillars, changes its skin four times during its growth. The intervals at which the four moultings follow each other depend much on climate or temperature, as well as on the quality and quantity of food. It is thence found, that if they are exposed to a high temperature, say from $81^{\circ}$ to $100^{\circ}$ Fahrenheit, the moultings will be hastened; and only five days will be consumed in moulting the third or fourth time, whilst those worms that have not been hastened take seven or eight days.*

The period of the moultings is also influenced by the temperature in which the eggs have been kept during the winter. When the heat of the apartment has been regulated, the first moulting takes place on the fourth or filth day after hatching, the second begins on the eighth day, the third takes up the thirtcenth and fourteenth days, and the last occurs

* Cours d'Agriculture, par M. Rozier. Paris, 1801.

VOL. IV. 
on the twenty-sccond and twenty-third days. 'The fifth age, in such cases, lasts ten days, at the end of which, or thirty-two days after hatching, the caterpillars attain their full growth, and ought to be three inches in length; but if they have not been properly fed, they will not be so long.

With the age of the caterpillar, its appetite increases, and is at its maximum after the fourth moulting, when it also attains its greatest size. The silk gum is then elaborated in the reservoirs, while the caterpillar ceases to eat, and soon diminishes again in size and weight. This usually requires a period of nine or ten days, commencing from the fourth moulting, after which it begins to spin its shroud of silk. In this operation it proceeds with the greatest caution, looking carefully for a spot in which it may be most secure from interruption.

" We usually," says the Abbé de la Pluche, "give it some little stalks of broom, heath, or a piece of paper rolled up, into which it retires, and begins to. move its head to different places, in order to fasten its thread on every side. All this work, though it looks to a bystander like confusion, is not without design. The caterpillar neither arranges its threads nor disposes one over another, but contents itself with distending a sort of cotton or floss to keep off the rain; for Nature having ordained silk-worms to work under trees, they never change their method, even when they are reared in our houses.

" When my curiosity led me to know how they spun and placed their beautiful silk, I took one of them, and frequently removed the floss with which it first attempted to make itself a covering; and as by this means I weakened it exceedingly, when it at last became tired of beginning anew, it fastened its threads on the first thing it encountered, and began to spin very regularly in my presence, bending its head up 
and down, and crossing to every side. It soon confined its movements to a very contracted space, and, by degrees, entirely surrounded itself with silk; and the remainder of its operations became invisible, though these may be understood from examining the work after it is finished. In order to complete the structure, it must draw out of the gum-bag a more delicate silk, and then with a stronger gum bind all the inner threads over one another.

"Here, then, are three coverings entirely different, which afford a succession of shelter. The outer loose silk, or floss, is for keeping off the rain; the fine silk in the middle prevents the wind from causing injury; and the glued silk, which composes the tapestry of the chamber where the insect lodges, repels both air and water, and prevents the intrusion of cold.

"After building her cocoon, she divests herself of her fourth skin, and is transformed into a chrysalis, and subsequently into a moth (Bombyx mori), when, without saw or centre-bit, she nakes her way through the shell, the silk, and the floss; for the Being who teaches her how to build herself a place of rest, where the delicate limbs of the moth may be formed without interruption, instructs her likewise how to open a passage for escape.

"The cocoon is like a pigeon's egg, and more pointed at one end than the other; and it is remarkable that the caterpillar does not interweave its silk towards the pointed end, nor apply its glue there as it does in every other part,* by bending itself all around with great pliantness and agility; what is more, she never fails, when her labour is finished, to fix her head opposite to the pointed extremity. The reason of her taking this position is, that she has

* This is denied by recent observers. 
purposely left this part less strongly cemented, and less exactly closed. She is instinctively conscious that this is to be the passage for the perfect insect which she carries in her bowels, and has therefore the additional precaution never to place this pointed extremity against any substance that might obstruct the moth at the period of its egress.

"When the caterpillar has exhausted herself to furnish the labour and materials of the three coverings, she loses the form of a worm, her spoils drop all around the chrysalis; first throwing off her skin, with the head and jaws attached to it, and the new skin hardening into a sort of leathery consistence. Its nourishment is already in its stomach, and consists of a yellowish mucus, but gradually the rudiments of the moth unfold themselves, - the wings, the antennæ, and the legs becoming solid. In about a fortnight or three weeks, a slight swelling in the chrysalis may be remarked, which at length produces a rupture in the membrane that covers it, and by repeated efforts the moth bursts through the leathery envelope into the chamber of the cocoon.

"The moth then extends her antennæ, together with her head and feet, towards the point of the cone, which not being thickly closed up in that part gradually yields to her efforts; she enlarges the opening, and at last comes forth, leaving at the bottom of the cone the ruins of its former state-namely, the head and entire skin of the caterpillar, which bear some resemblance to a heap of foul linen." **

Reaumur was of opinion that the moth makes use of its eyes as a file, in order to effect its passage through the silk; while Malpighi, Peck, and others, believe that it is assisted by an acid which it discharges in order to dissolve the gum that holds the

* Spectacle de la Nature, vol. i. 
fibres of the silk together (see p. 196). Mr Swayne denies that the threads are broken at all, either by filing or solution; for he succeeded in unwinding a whole cocoon from which the moth had escaped. The soiling of the cocoon by a fluid, however, we may remark, is no proof of the acid; for all moths and butterflies discharge a fluid when they assume wings, whether they be inclosed in a cocoon or not; but it gives no little plausibility to the opinion, that " the end of the cocoon is observed to be wetted for an hour, and sometimes several hours, before the moth makes its way out." ${ }^{*}$ Other insects employ different contrivances for escape, as we have already seen, and shall still further exemplify.

It is the middle portion of the cocoon, after removing the floss or loose silk on the exterior, which is used in our manufactures; and the first preparation is to throw the cocoons into warm water, and stir them about with twigs, to dissolve any slight gummy adhesions which may have occurred when the caterpillar was spinning. The threads of several cones, according to the strength of the silk wanted, are then taken and wound off upon a reel. The refuse, consisting of what we may call the tops and bottoms of the cones, are not wound, but carded, like wool or cotton, in order to form coarser fabrics. We learn from the fact of the cocoons being generally unwound without breaking the thread, that the insect spins the whole without interruption. It is popularly supposed, however, that if it be disturbed during the operation by any sort of noise, it will take alarm, and break its thread; but Latreille says this is a vulgar error. $\dagger$

* Count Daudolo's Art of Rearing Silk-Worms, Eng. Transl. p. 215.

$\dagger$ On a tort de croire que le bruit nuise à ces insectes. Hist. Nat. Gén ral., vol. xiii., p. 170.

voI.. IV 
The length of the unbroken thread in a cocoon varies from six hundred to a thousand feet; and as it is all spun double by the insect, it will amount to nearly two thousand feet of silk, the whole of which does not weigh above three grains and a half: five pounds of silk from ten thousand cocoons is considerably above the usual average. When we consider, therefore, the enormous quantity of silk which is used at present, the number of worms employed in producing it will almost exceed our comprehension. The manufacture of the silk, indeed, gives employment, and furnishes subsistence, to several millions of human beings; and we may venture to say, that there is scarcely an individual in the civilised world who has not some article made of silk in his possession.

In ancient times, the manufacture of silk was confined to the East Indies and China, where the insects that produce it are indigenous. It was thence brought to Europe in small quantities, and in early times sold at so extravagant a price, that it was deemed too expensive even for royalty. The Emperor Aurelian assigned the expense as a reason for refusing his empress a robe of silk; and our own James I., before his accession to the crown of England had to borrow of the Earl of Mar a pair of silk stockings to appear in before the English ambassador,-a circumstance which probably led him to promote the cultivation of silk in England.* The Roman authors were altogether ignorant of its origin,some supposing it to be grown on trees as hair grows on animals, -others that it was produced by a shell-fish similar to the mussel, which is known to throw out threads for the purpose of attaching itself to rocks, - others that it was the entrails of a sort of

* Shaw's Gen. Zoology, vol. vi. 
spider, which was fed for four years with paste, and then with the leaves of the green-willow, till it burst with fat,-and others that it was the produce of a worm which built nests of clay and collected wax. The insect was at length spread into Persia; and eggs were afterwards, at the instance of the Emperor Justinian, concealed in hollow canes by two monks, and coveyed to the isle of Cos. This emperor, in the sixth century, caused them to be introduced into Constantinople, and made an object of public utility. They were thence successively cultivated in Greece, in Arabia, in Spain, in Italy, in France, and in all places where any hope could be indulged of their succeeding. In America, the culture of the silk-worm was introduced into Virginia in the time of James I., who himself composed a book of instructions on the subject, and caused mulberry trees and silk-worm's eggs to be sent to the colony. In Georgia, also, lands were granted on condition of planting one hundred white mulberry-trees on every ten acres of cleared land.*

The growth of the silk-worm has also been tried, but with no great success, in this country. Evelyn computed that one mulberry-tree would feed as many silk-worms annually as would produce seven pounds of silk. "According to that estimate," says Barham "the two thousand trees already planted in Chelsea Park (which take up one-third of it) will make 14,000lbs. weight of silk; to be commonly worth but twenty shillings a pound, those trees must make $£ 14,000$ per annum." During the last century, some French refugees in the south of Ireland made considerable plantations of the mulberry, and had begun

* North American Review, Oct. 1828, p. 449.

+ Essay on the Silk-Worm, p 95 . London, 1719. 
the cultivation of silk with every appearance of success; but since their removal the trees have been cut down.* In the vicinity of London, also, a considerable plantation of mulberry-trees were purchased by the British, Irish, and Colonial Silk Company in 1825; but we have not learned whether this Company have any active measures now in operation.

The manufacture of silk was introduced into this country in 1718 , at Derby, by $\mathrm{Mr}$ John Lombe, who travelled into Italy to obtain the requisite information; but so jealous were the Italians of this, that according to some statements which have obtained belief, he fell a victim to their revenge, having been poisoned at the early age of twenty-nine. $†$

There are not cnly several varieties of the common silk-worm (Bombyx mori), but other species of caterpillars, which spin silk capable of being manufactured, though not of so good qualities as the common silk. None of our European insects, however, seem to be well fitted for this purpose, though it has been proposed by Fabricius and others to try the crimson under-wing (Calocala sponsa, ScHrivk), \&c. M. Latreille quotes from the 'Recreations of Natural History,' by Wilhelm, the statement that the cocoons of the emperor-moth (Saturnia paronia) had been successfully tried in Germany, by M. Wentzel Hegeer de Berchtoldscori, under an imperial patent.

\section{Emperor-Moth.}

The emperor-moth, indeed, is no less worthy of our attention with respect to the ingenuity of its architecture, than the beauty of its colours, and has

* Preface to Dandolo on the Silk-Worm, Eng. Transl.p.xiii.

+ Glover's Directory of the County of Derby, introd. p. xvi. 
consequently attracted the attention of every Entomologist. The caterpillar feeds on fruit-trees and on the willow, and spins a cocoon, in form of a Florence flask, of strong silk, so thickly woven, that it appears almost like damask or leather. It differs from most other cocoons in not being closed at the upper or smaller end, which terminates in a narrow circular aperture, formed by the convergence of little bundles of silk, gummed together, and almost as elastic as whalebone. In consequence of all these terminating in needle-shaped points, the entrance of depredators is guarded against, upon the principle which prevents the escape of a mouse from a wire trap. The insect, however, not contented with this protection, constructs another in form of a canopy or dome, within the external aperture, so as effectually to shield the chrysalis from danger. We have formerly remarked (page 192) that the caterpillar of the Egeria asiliformis of Stephens, in a similar way did not appear to be contented with a cnvering of thin wood, without an additional bonnet of brown wax. The cocoon of the emperor-moth, though
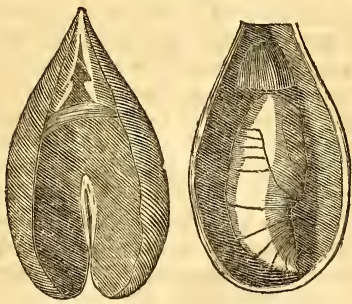

Cocoons of the Emperor-moth cut open to show their structure. 
thus in some measure impenetrable from without, is readily opened from within; and when the moth issues from its pupa case, it easily makes its way out without either the acid or eye-files ascribed to the silk-worm. The elastic silk gives way upon being pushed from within, and when the insect is fairly out, it shuts again of its own accord, like a docr with spring hinges, - a circumstance which at first puzzled Roesel not a little when he saw a fine large moth in his box, and the cocoon apparently in the same state as when he had put it there. Another naturalist conjectures that the converging threads are intended to compress the body of the moth as it emerges in order to force the fluids into the nervures of the wings; for when he took the chrysalis previously out of the cocoon, the wings of the moth never expanded properly.* Had he been much conversant: with breeding insects, he would rather, we think, have imputed this to some injury which the chrysalis had received. We have witnessed the shrivelling of the wings which he alludes to, in many instances, and not unfrequently in butterflies which spin no cocoon. The shrivelling, indeed, frequently arises from the want of a sufficient supply of food to the caterpillar in its last stage, occasioning a deficiency in the fluids. - The elasticity of the cocoon is not peculiar to the emperor-moth. A much smaller insect, the green cream-border-moth (Tortrix chlorana) before mentioned (page 170), for its ingenuity in bundling up the expanding leaves of the willow, also spins an elastic shroud for its chrysalis, of the singular shape of a boat with the keel uppermost. Like the caterpillar of Pyralis strigulalis (page 198), whose building, though of different materials, is exactly of the same form, -it first spins two approximating walls

Meinecken, quoted by Kirby and Epence, iii. 280. 
of whitish silk, of the form required, and when these are completed, it draws them forcibly together with elastic threads, so placed as to retain them closely shut. The passage of the moth out of this cocoon might have struck Roesel as still more marvellous than that of his emperor, in which there was at least a small opening; while in the boat cocoon there is none. We have now before us two of these, which we watched the caterpillars through the process of building, in the summer of 1828 , and from one only a moth issued,- - the other, as often happens, having died in the chrysalis. But what is most remarkable, it is impossible by the naked eye to tell which of these two has been opened by the moth, so neatly has the joining been finished.*

Some species of moths spin a very slight silken. tissue for their cocoous, being apparently intended more to retain them from falling, than to afford protection from other accidents. The gipsey-moth (Hypogymna dispar), rare in most parts of Britain, is one of these. It selects for its retreat a crack in the bark of the tree upon which it feeds, and over this spius only a few straggling threads. We found last summer (1829), in the hole of an elm-tree in the Parc at Brussels, a group of half a dozen of these, that did not seem to have spun any covering at all, but trusted to a curtain of moss (Hypna) which margined the entrance. $\dagger$ In a species nearly allied to this, the yellow-tussock (Dasychira pudibunda, STEPHENs), the cocoon, one of which we have now before. us, is of a pretty close texture, and interwoven with the long hairs of the caterpillar itself (see the right hand top figure, page 20), which it plucks out piecemeal during the process of building, - as is also done 
by the vapourer (Orgyia antiqua, Mubner), and many others.

These are additional instances of the remarks we formerly made, that caterpillars which spin a slight web are transformed into perfect insects in a much shorter period than those which spin more substantial ones. Thus the cream-spot tyger (Arctia villica, Stephens) lies in the chrysalis only three weeks, and therefore does not require a strong web. It is figured below, along with another, which is still slighter, though more ingeniously woven, being regularly meshed like net-work.

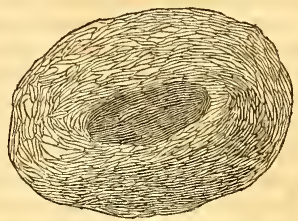

Cocoon of Arctia villica.

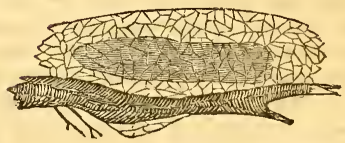

N'ct work cocoon.

A very prettily netted cocoon is constructed by the grub of a very small grey weevil (Hypera Rumicis), which is not uncommon in July, on the seed spikes of docks (Rumices). This cocoon is globular, and not larger than a garden pea, though it appears to 
be very large in proportion to the pupa of the insect, reminding us not a little of the carved ivory balls fiom China. The meshes of the net-work are also large, but the materials are strong and of a waxy consistence. Upon remarking that no netting was ever spun over the part of the plant to which the cocoon was attached, we endeavoured to make them spin cocoons perfectly globular, by detaching them when nearly finished; but though we tried four or five in this way, we could not make them add a single mesh after removal, all of them making their escape through the opening, and refusing to re-enter in order to complete their structure.*

The silk, if it may be so termed, spun by many species of larvæ is of a still stronger texture than the waxy silk of the little weevil just mentioned. We recently met with a remarkable instance of this at Lee, in the cocoons of one of the larger ichneumons (Ophion Vinulce? Stephens), inclosed in that of a puss-moth (Cerura Vinula)-itself remarkable for being composed of sand as well as wood, the fibres of which had been scooped out of the underground cross-bar of an old paling, to which it was attached. But the most singular portion of this was the junction of the outer wall with the edges of the hollow thus scooped out, which was formed of fibres of wood placed across the fibres of the bar nearly at right angles, and strongly cemented together, as if to form a secure foundation for the building.

In this nest were formed, surreptitiously introduced into the original building, five empty cells of a black colour, about an inch long, and a sixth of an inch in diameter; nearly cylindrical in form, but somewhat flattened; vertical and parallel to one another, though slightly curved on the inner side. The cells are com-

$$
\text { * J. R. }
$$

FOL. IV. 
posed of strong and somewhat coarse fibres, more like the carbonized rootlets of a tree than silk, and resembling in texture a piece of coarse milled cloth or felt, such as is used for the bases of plated hats. It is worthy of remark, that all these cells opened

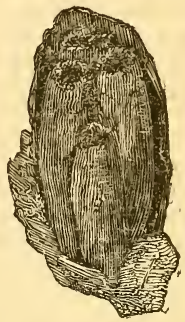

Nest of Puss-Moth, inclosing five cocoons of an Ichneumon. Natural size.

towards one end, as if the caterpillars which constructed them had been aware that the wall of the puss-moth, in which the flies would have to make a breach, was very hard, and would require their united efforts to effect an escape. The importance of such a precaution will appear more strikingly, when we compare it with the instance formerly mentioned (page 195), in which only one ichneumon had been able to force its way out.*

It appears indispensable to some grubs to be confined within a certain space, in order to construct their cocoons. We saw this well exemplified in the instance of a grub of one of the mason-bees (Osmia bicornis), which we took from its nest, and put into 
a box, with the pollen paste which the mother bee had provided for its subsistence. (See pages 40,41.) When it had completed its growth, it began to spin, but in a very awkward manner-attaching threads, as if at random, to the bits of pollen which remained undevoured, and afterwards tumbling about to another part of the box, as if dissatisfied with what it had done. It sometimes persevered to spin in one place till it had formed a little vaulted wall; but it abandoned at the least three or four of these in order to begin others, till at length, as if compelled by the extreme urgency of the stimulus of its approaching change, it completed a shell of shining brown silk, woven into a close texture. Had the grub remained within the narrow clay cell built for it by the mother bee, it would, in all probability, not have thus exhausted itself in vain efforts at building, which were likely to prevent it from ever arriving at the perfect state-a circumstance which often happens in the artificial breeding of insects.*

Beside silk, the cocoons of many insects are composed of other animal secretions, intended to strengthen or otherwise perfect their texture. We have already seen that some caterpillars pluck off their own hair to interweave amongst their silk: there are others which produce a peculiar substance for the same purpose. The lackey caterpillar (Clisiocampa neustria, Curtis) in this manner lines its cocoon with pellets of a downy substance, resembling little tufts of the flowers of sulphur. The small egger, again (Eriogaster lanestris, Germar), can scarcely be said to employ silk at all,- the cocoon being of a uniform texture, looking, at first sight, like dingy Paris plaster, or the shell of a pheasant's egg, but upon being broken, and 
inspected narrowly, a few threads of silk may be seen interspersed through the whole. In size, it is not larger than the egg of the gold-crested wren. It has been considered by Brahm a puzzling circumstance, that this cocoon is usually perforated with one or two little holes, as if made by a pin from without; and Kirby and Spence tell us that their use has not been ascertained.* May they not be left as air-holes for the included chrysalis, as the close texture of the cocoon might, without this provision, prove fatal to the animal? Yet, on comparing one of these with a similar cocoon of the large egger-moth ( $\mathrm{La}-$ siocampa Quercus), we find no air-holes in the latter, as we might have been led to expect from the closeness of its texture. We found a cocoon of a saw-fly (Trichiosoma), about the same size as that of the egger, attached to a hawthom twig, in a hedge at New Cross, Deptford, but of a leathery texture, and, externally, exactly the colour of the bark of the tree. This was also without air-holes. The egger, we may remark, unlike the dock-weevil or the bee-grub just mentioned, can work her cocoon without any point of attachment. We had a colony of these caterpillars in the summer of 1825, brought from Epping Forest, and saw several of them work their cocoons, and we could not but admire the dexterity with which they avoided filling up the little pin holes. The supply of their building material was evidently measured out to them in the exact quantity required; for when we broke down a portion of their wall, by way of experiment, they did not make it above half the thickness of the previous portion, though they plainly preferred having a thin wall to leaving the breach unclosed. $\dagger$

Several species of caterpillars that spin only silk,

* Brahm's Ins. Nat. 289, and Kirby and Spence's Intr. iii. 223. $+\mathbf{J} . \mathbf{R}$. 
are sucial, like some of those we formerly mentioned, which unite to form a common tent of leaves (see pages $17 \%, 3$ ). The most common instance of this, is in the caterpillars which feed on the nettle-the small tortoise-shell (Vanessa urtica), and the peacock's eye ( $\boldsymbol{V} . \mathbf{l}$.j.) Colonies of these may be seen, after Midsummer, on almost every clump of nettles, inhabiting a thin web of an irregular oval shape, from which they issue out to feed on the leaves, always returning when their appctite is satisfied, to assist their companions in extending their premises. Other examples still more conspicuous from being seen on fruit-trees and in hedges, occur in the caterpillars of the small ermine-moth (Y ponomeuta padella), and of the lackey (Clisiocampa neustria), which in some years are but too abundant, though in others they are seldom met with. In the summer of 1826 , every hedge and fruit-tree around London swarmed with colonies of the ermine, though it has not since been plentiful; and in the same way, during the summer of 1829 , the lackeys were to be seen every where. We mention this irregularity of appearance, that our readers may not disappoint themselves by looking for what is not always to be found. It is probable, that in 1830, the lackeys will be few, for notwithstanding the myriads of caterpillars last summer, we saw only a single moth of this species, and out of a number of chrysalides which a young friend had in his nurse-boxes, not one moth was bred.

The caterpillars of other moths, which are in some years very common-such as the brown-tail (Porthesia auriflua,) and the golden-tail ( $P$. Chrysorrhce () , are also social; and, as the eggs are hatclied late in the summer, the brood passes the winter in a very closely woven nest of waim silk. This is usually represented as composed of leaves which have had their pulpy parts eaten as food

VOL. IV. 28* 
by the colonists; but from minute observation of at least twenty of these nests in the winter of 1828-9, we are quite satisfied that leaves are only an accidental, and not a necessary part of the structure. When a leaf happens to be in the line of the walls of the nest, it is included; but there is no apparent design in pressing it into the service, nor is a branch selected because it is leafy. On the contrary, by far the greater number of these nests do not contain a single leaf, but are composed entirely of grey silk. In external form, no two of these nests are alike; as it depends entirely upon the form of the branch. When, therefore, there is only one twig, it is somewhat egg-shaped; but when there are several twigs, it commonly joins each, assuming an angular shape, as may be seen in the figure.

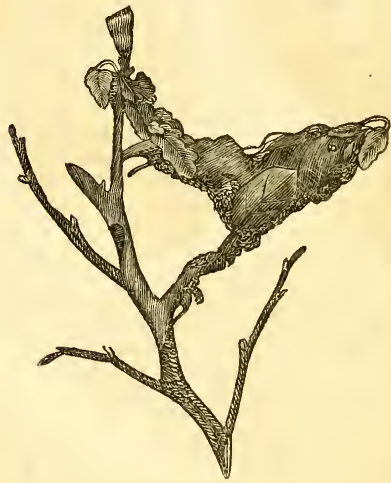

Winter nest of the Social Catcrpillars of the Brown tail Moth (Porthesia aurillun), figured from specimen. 
This irregularity arises from the circumstance of each individual acting on its own account, without the direction or superintendence of the others. The interior of the structure is, for the same reason, more regular, being divided into compartments, each of which forms a chamber for one or more individuals. Previous to the cold weather, these chambers have but slight partitions; but before the frosts set in the whole is made thick and warm.

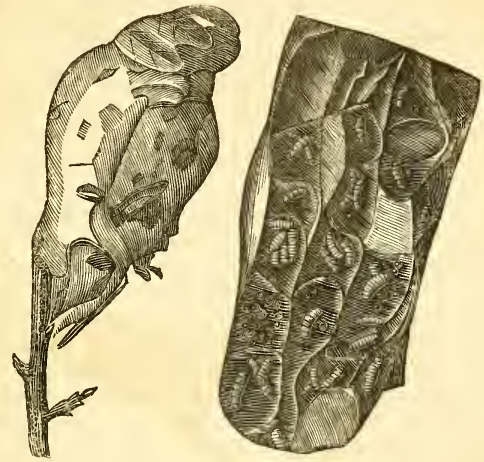

Winter nests of Porthesia chrysorrhaa, one being cut opcn to show the chambers. The dots represent the egesta of the caterpillars.

A no less remarkable winter nest, of a small species of social caterpillar is described by M. Bonnet, which we omitted to introduce when treating of the Glanville fritillary (page 172). 'The next in question is literally pendulous, being hung from the branch of a fruit-tree by a strong silken thread. It consists of one or two leaves neatly folded, and held together 
with silk, in which the caterpillars live harmoniously together.

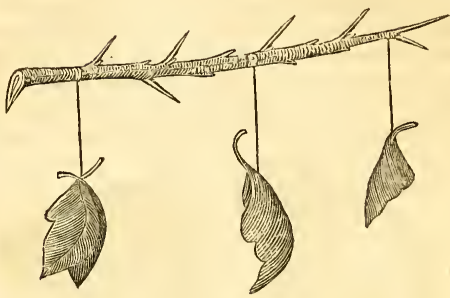

Pendulous leaf-nests, from Bonnet.

In a recently published volume of 'Travels in Mexico,' we find a very remarkable account of some pendulous nests of caterpillars, which appear to be almost as curious as the nests of the card-maker wasps, described at p. 88 . The author of these travels does not define the species of caterpillar, whose constructions excited his observation. $\mathrm{He}$ says, "After having ascended for about an hour, we came to the region of oaks and other majestically tall trees, the names of which I could not learn. Suspended from their stately branches, were innumerable nests, enclosed, apparently, in white paper bags, in the manner of bunches of grapes in England, to preserve them from birds and flies. I had the curiosity to examine one of them, which I found to contain numberless caterpillars. The texture is so strong that it is not easily torn; and the interior contained a quantity of green leaves, to support the numerous progeny within."

* Hardy's Travels in the Interior of Mexico, p. 32. 
In all the nests of social caterpillars, care is taken to leave apertures for passing out and in. It is remarkable, also, that however far they may ramble from their nest, they never fail to find their way back, when a shower of rain or nightfall renders shelter necessary. It requires no great shrewdness to discover how they effect this; for by looking closely at their track it will be found that it is carpeted with silk-no individual moving an inch without constructing such a pathway, both for the use of his companions and to facilitate his own return. All these social caterpillars, therefore, move more or less in processional order, each following the road which the first chance traveller has marked out with his strip of silk carpeting.

There are some species, however, which are more remarkable than others in the regularity of their processional marchings, particularly two which are found in the South of Europe, but are not indigenous in Britain. The one named by Réaumur the processionary (Cnethocampa processionea, Stephens) feeds upon the oak; a brood dividing, when newly hatched into one or more parties of several hundred individuals, which afterwards unite in constructing a common nest nearly two feet long, and from four to six inches in diameter. As it is not divided like that of the brown-tails into chambers, but consists of one large hall, it is not necessary that there should be more openings than one; and accordingly when an individual goes out and carpets a path, the whole colony instinctively follow in the same track, though from the immense population they are often compelled to march in parallel files from two to six deep. The procession is always headed by a single caterpillar; sometimes the leader is immediately followed by one or two in single file, and sometimes by two abreast, as represented in the cut. A similar pro- 
cedure is followed by a species of social caterpillars, which feed on the pine in Savoy and Languedoc; and though their nests are not half the size of the preceding, they are more worthy of notice, from the strong and excellent quality of their silk, which Reaumur was of opinion might be advantageously manufactured. Their nests consist of more chambers than one, but are furnished with a main entrance, through which the colonists conduct their foraging processions.

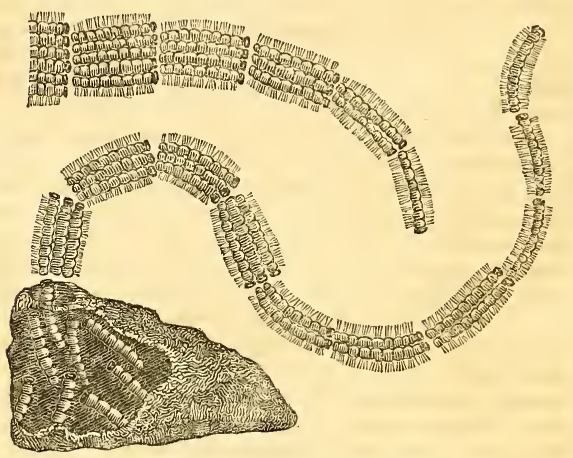

Nest and order of marching of the Processionary Caterpillars of the oak (Cnethocampa processionea). 


\section{Cinafter XViII.}

Structures of Spiders.

Modern naturalists do not rank spiders among insects because they have no antennæ, and no division between the head and the shoulders; they breathe by leaf-shaped gills, situated under the belly, instead of spiracles in the sides; have a heart connected with these; have eight legs instead of six; and eight fixed eyes. But as spiders are popularly considered insects, it will sufficiently suit our purpose to introduce them here as such.

The apparatus by which spiders construct their ingenious fabrics is much more complicated than that which we have described, as common to the various species of caterpillars. Caterpillars have only two reservoirs for the materials of their silk; but spiders, according to the dissections of M. Treviranus, have four principal vessels, two larger and two smaller, with a number of minute ones at their base. Several small tubes branch towards the reservoirs, for carrying to them, no doubt, a supply of the secreted material. Swammerdam describes them as twisted into many coils of an agate colour.* We do not find them coiled but nearly straight, and of a deep yellow colour. From these when broken, threads can be drawn out like those spun by the spider.

From these little flasks or bags of gum, situated near the anus, and not at the mouth as in caterpillars, a tube originates and terminates in the exter-

* Hill's Swammerdam, part i. p. 23. 
nal spinerets, which may be seen by the naked eye in the larger spiders, in the form of five little teats surrounded by a circle, as represented in the figure below.

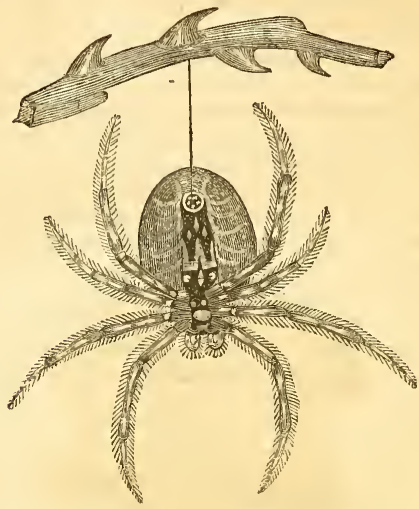

Garden Spider (Epeira diadema), suspended by a thread proeceding fiom its spinneret.

We have seen that the silken thread of a caterpillar is composed of two united within the tube of the spinneret, but the spider's thread would appear from the first view of its five spinnerets, to be quintuple, and in some spccies which have six teats, so many times more. It is not safe, however, in our interpretations of nature to proceed upon conjecture however plausible, nor to take any thing for granted which we have not actually seen; since our inferences in such cases are almost certain to bc erroneous. 
If Aristotle, for example, had ever looked narrowly at a spider when spinning, he could not have fancied, as he does, that the materials which it uses are nothing but wool stripped from its body. On looking then, with a strong magnifying glass, at the teatshaped spinnerets of a spider, we perceive them studded with regular rows of minute bristle-like points, about a thousand to each teat, making in all from five to six thousand. These are minute tubes which we may appropriately term spinnerules, as each is connected with the internal reservoirs, and emits a thread of inconceivable fineness. In the figure below, this wonderful apparatus is represented as it appears in the microscope.

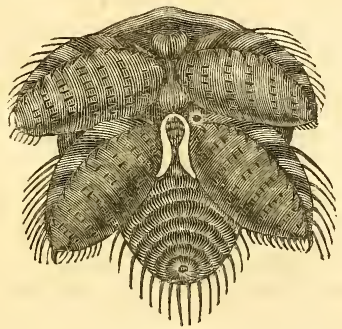

Spinnerets of a Spider magnified to show the Spinnerules.

We do not recollect that naturalists have ventured to assign any cause for this very remarkable multiplicity of the spinnerules of spiders, so different from the simple spinneret of caterpillars. To us it appears to be an admirable provision for their mode of life. Caterpillars neither require such strong materials, nor that their thread should dry as quickly.

voL. IV. 
It is well known in our manufactures, particularly in rope-spinning, that in cords of equal thickness, those which are composed of many smaller ones united are greatly stronger than those which are spun at once. In the instance of the spider's thread, this principle must hold still more strikingly, inasmuch as it is composed of fluid materials that require to be dried rapidly, and this drying must be greatly facilitated by exposing so many to the air separately before their union, which is effected at the distance of about a tenth of an inch from the spinnerets. In the following figure, each of the threads represented is reckoned to contain one hundred minute threads, the whole forming only one of the spider's common threads.

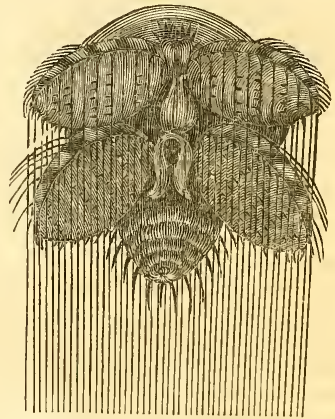

A single thread of a Spider, greatly magnified, so that, fur the small space represented, the lines are shewn as parallel.

Leeuwenhoeck, in one of his extraordinary microscopical observations on a young spider not bigger than a grain of sand, upon enumerating the thread- 
lets in one of its threads, calculated that it would require four millions of them to be as thick as a hair of his beard.

Another important advantage derived by the spider from the multiplicity of its threadlets is, that the thread affords a much more secure attachment to a wall, a branch of a tree, or any other object, than if it were simple; for, upon pressing the spinneret against the object, as spiders always do when they fix a thread, the spinnerules are extended over an area of some diameter, from every hair's breadth of which a strand, as rope-makers term it, is extended to compound the main cord. The following figure exhibits this ingenious contrivance.

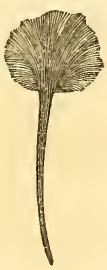

Attached end of a Spider's thread magnified.

Those who may be curious to examine this contrivance will see it best when the line is attached to any black object; for the threads being white are, in other cases not so easily perceived.

\section{Shooting of the Lines.}

It has long been considered a curious, though a difficult investigation, to determine in what manner 
spiders, seeing that they are destitute of wings, transport themselves from tree to tree, across brooks, and fiequently through the air itself, without any apparent starting point. On looking into the authors who have treated upon this subject, it is surprising how little there is to be met with that is new, even in the most recent. Their conclusions, or rather their conjectural opinions, are, however, worthy of notice; for, by unlearning error, we the more firmly establish truth.

1. One of the earliest notions upon this subject is that of Blancanus, the commentator on Aristotle, which is partly adopted by Redi, by Henricus Regius of Utrecht by Swammerdam,* by Lehmann the mineralogist, anc Kirby and Spence. $\dagger$ "The spider's thread," says Swammerdam, " is generally made up of two or more parts, and after descending by such a thread, it ascends by one only, and is thus enabled to waft itself from one height or tree to another, even across running waters; the thread it leaves loose behind it being driven about by the wind, and so fixed to some other body." "I placed," says Kirby, " the large garden spider (Epeira diadema) upon a stick about a foot long, set upright in a vessel containing water. . . . . It let itself drop, not by a single thread, but by two, each distant from the other, about the twelfth of an inch, guided, as usual, by one of its hind feet, and one apparently smaller than the other. When it had suffered itself to descend nearly to the surface of the water, it stopped short, and by some means, which I could not distinctly see, broke off, close to the spinners, the smallest thread, which still adhering by the other end to the top of the stick,

* Swammerdam, part i. p. 24.

+ Intr. i. vol. p. 415 . 
floated in the air, and was so light as to be carried about by the slighest breath. On' approaching a pencil to the loose end of this line, it did not adhere from mere contact. I, therefore, twisted it once or twice round the pencil, and then drew it tight. The spider, which had previously climbed to the top of the stick, immediately pulled at it with one of its feet, and finding it sufficiently tense, crept along it, strengthening it as it proceeded by another thread, and thus reached the pencil."

We have repeatedly witncssed this ocurrence, both in the fields, and when spiders were placed for experiment, as Kirby has described; but we very much doubt that the thread broken is ever intended as a bridge cable, or that it would have been so used in that instance, had it not been artificially fixed and accidentally found again by the spider. According to our observations, a spider never abandons, for an instant, the thread which she despatches in quest of an attachment, but uniformly keeps trying it with her feet, in order to ascertain its success. We are, therefore, persuaded, that when a thread is broken in the manner above described, it is because it has been spun too weak, and spiders may often be seen breaking such threads in the process of netting their webs.*

The plan, besides, as explained by these agreeable writers, would more frequently prove abortive than successful, from the cut thread not being sufficiently long. They admit, indeed, that spiders' lines are often found " a yard or two long, fastened to twigs of grass not a foot in height. .... Here, therefore, some other process must have been used." $†$

2. Our celebrated English naturalist, Dr Lister, whose treatise upon our native spiders has been the

* J. R.

voL. IV.

+ Kirby and Spence, vol. i. Intr. p 416. $29 *$ 
basis of every subsequent work on the subject, maintains, that "some spiders shoot out their threads in the same manner that porcupines do their quills; that whereas the quills of the latter are entirely separated from their bodies, when thus shot out, the threads of the former remain fixed to their anus, as: the sun's rays to its body." * A French periodical writer goes a little farther, and says, that spiders have the power of shooting out threads, and directing. them at pleasure, towards a determined point, judging of the distance and position of the object by some sense of which we are ignorant. $\dagger$ Kirby also says, that he once observed a small garden spider (Aranea reticulata), "standing midway on a long perpendicular fixed thread, and an appearance caught" his " cye, of what seemed to be the emission of threads." "I," therefore, he adds, "moved my arm in the direction in which they apparently proceeded, and, as I had suspected, a floating thread attached itself to my coat, along which the spider crept. As this was connected with the spinners of the spider, it could not have been formed" by breaking a "secondary thread." + Again, in speaking of the gossamer-spider, he says, it "first extends its thigh, shank, and foot, into a right line, and then, elevating its abdomen till it becomes vertical, shoots its thread into the air, and flies off from its station." $\$$

Another distinguished naturalist, $\mathrm{Mr}$ White of Selborne, in speaking of the gossamer-spider, says, " every day in fine weather in autumn do I see these spiders shooting out their webs and mounting aloft: they will go off from the finger, if you will take them into your hand. Last summer, one alighted on my book as $I$ was reading in the par-

* Lister, Hist. Animalia Angliæ, 4to. p. 7.

+ Phil. Mag. ii. p. 275.

$\ddagger$ Vol. i. Intr. p. 417.

§ Ibid. ii. p. 339. 
lour; and running to the top of the page, and shooting out $a$ web, took its departure from thence. But what I most wondered at was, that it went off with considerable velocity in a place where no air was stirring; and I am sure that I did not assist it with my breath."

Having so often witnessed the thread set afloat in the air by spiders, we can readily conceive the way in which those eminent naturalists were led to suppose it to be ejected by some animal force acting like a syringe; but as the statement can be completely disproved by experiment, we shall only at present ask, in the words of Swammerdam-" how it can be possible that a thread so fine and slender should be shot out with force enough to divide and pass through the air?-is it not rather probable that the air would stop its progress, and so entangle it and fit it to perplex the spider's operations?" $\dagger$ The opinion, indeed, is equally improbable with another, suggested by Dr Lister, that the spider can retract her thread within the abdomen, after it has been emitted. $\ddagger$ De Geer§ very justly joins Swammerdam in rejecting both of these fancies, which, in our own earlier observations upon spiders, certainly struck us as plausible and true. There can be no doubt, indeed, that the animal has a voluntary power of permitting the material to escape, or stopping it at pleasure, but this power is not projectile.

3. "There are many people," says the Abbé de la Pluche, "who believe that the spider flies when they see her pass from branch to branch, and even from one high tree to another; but she transports herself in this manner: she places herself upon the end of a branch,

* Nat. Hist. of Selborne, vol. i. p. 327.

+ Book of Nature, part i. p. 25.

$\ddagger$ Hist. Anim. Angliæ, 4to.

Memoires, vol. vii. p. 189. 
or some projecting body, and there fastens her thread; after which, with her two hind feet, she squeezes her dugs (spinnerts), and presses out one or more threads of two or three ells in length, which she leaves to float in the air till it be fixed to some particular place."* Without pretending to have observed this, Swammerdam says, " I can easily comprehend how spiders, without giving themselves any motion, may, by only compressing their anus, spin out a thread, which being driven by the wind, may serve to waft them from one place to another." Others, proceeding upon a similar notion, give a rather different account of the matter. "The spider," says Bingley, "fixes one end of a thread to the place where she stands, and then with her hind paws draws out several other threads from the nipples, which, being lengthened out and driven by the wind to some neighbouring tree or other object, are by their natural clamminess fixed to it."'

Observation gives some plausibility to the latter opinion, as the spider always actively uses her legs, though not to draw out the thread, but to ascertain whether it has caught upon any object. The notion of her pressing the spinneret with her feet must be a mere fancy; at least it is not countenanced by any thing which we have observed.

4. An opinion much more recondite is mentioned, if it was not started by M. D'Isjonval, that the floating of the spider's thread is ellectrical. "Frogs, cats, and other animals," he says, " are effected by natural electricity, and feel the change of weather; but no other animal more than myself and my spiders." During wet and windy weather he accordingly found that they spun very short lines, " but when a spider

* Spectacle de la Nature, vol. i.

+ Book of Nature, part i. p. 25.

$\ddagger$ Animal Biography, vol. iii. p. 475, 3rd edition. 
spins a long thread, there is a certainty of fine weather for at least ten or twelve days afterwards." periodical writer, who signs himself Carolan, $\nmid$ fancies that in darting out her thread the spider emits a stream of air, or some subtile electric fluid, by which she guides it as if by magic.

A living writer (Mr John Murray), whose learning and skill in conducting experiments give no little weight to his opinions, has carried these views considerably farther. "The aëronautic spider," he says, "can propel its threads both horizontally and vertically, and at all relative angles, in motionless air, and in an atmosphere agitated by winds; nay more, the aërial traveller can even dart its thread, to use a nautical phrase, in the 'wind's eye.' My opinion and observations are based on many hundred experiments..... The entire phenomena are electrical. When a thread is propelled in the vertical plane, it remains perpendicular to the horizontal plane, always upright, and when others are projected at angles more or less inclined, their direction is invariably preserved; the threads never intermingle, and when a pencil of threads is propelled, it ever presents the appearance of a divergent brush. These are electrical phenomena, and cannot be explained but on electrical principles."

"In clear, fine weather, the air is invariably positive; and it is precisely in such weather that the aëronautic spider makes its ascent most easily and rapidly, whether it be in summer or in winter." "When the air is weakly positive, the ascent of the spider will be difficult, and its altitude extremely limited, and the threads propelled will be but little elevated above the horizontal plane. When negative electricity prevails, as in cloudy weather, or on the

* Brez. Flore des Insectophiles. Notes, Supp. p. 134.

† Thomson's Ann. of Philosophy, vol. iii. p. 306. 
approach of rain, and the index of De Saussere's hygrometer rapidly advancing towards humidity, the spider is unable to ascend." "*

Mr Murray had previously told us, that "when a stick of excited sealing-wax is brought near the thread of suspension, it is evidently repelled; consequently, the electricity of the thread is of a negative character," while " an excited glass tube brought near, seemed to attract the thread, and with it, the aëronautic spider." $\uparrow$ His friend, Mr Bowman, further describes the aërial spider as "shooting out four or five, often six or eight, extremely fine webs several yards long, which waved in the breeze, diverging from each other like a pencil of rays." One of them "had two distinct and widely diverging fasciculi of webs," and " a line uniting them would have been at right angles to the direction of the breeze."'f

Such is the chief evidence in support of the electrical theory; but though we have tried these experiments, we have not succeeded in verifying any one of them. The following statements of $\mathrm{Mr}$ Blackwall come nearer our own observations.

5. "Having procured a small branched twig," says $\mathrm{Mr}$ Blackwall, "I fixed it upright in an earthen vessel containing water, its base being immersed in the liquid, and upon it I placed several of the spiders which produce gossamer. Whenever the insects thus circumstanced were exposed to a current of air, either naturally or artificially produced, they directly turned the thorax towards the quarter whence it came, even when it was so slight as scarcely to be perceptible, and elevating the abdomen, they emitted from their spinners a small portion of glutinous

* Loudon's Mag. of Nat. Hist., vol. i. p. 322.

+ Experim. Researches in Nat. Hist., p. 136.

‡ Mag. Nat. Hist., vol. j. p. 324. 
matter, which was instantly carried out in a line, consisting of four finer ones, with a velocity equal, or nearly so, to that with which the air moved, as was apparent from observations made on the motion of detached lines similarly exposed. The spiders, in the next place, carefully ascertained whether their lines had become firmly attached to any object or not, by pulling at them with the first pair of legs; and if the result was satisfactory, after tightening them sufficiently, they made them pass to the twig; then discharging from their spinners, which they applied to the spct where they stood, a little more of their liquid gum, and committing themselves to these bridges of their own constructing, they passed over them in salety, drawing a second line after them, as a security in case the first gave way, and so effected their escape.

"Such was invariably the result when spiders were placed where the air was liable to be sensibly agitated: I resolved, therefore, to put a bell glass over them; and in this situation they remained seventeen days, evidently unable to produce a single line by which they could quit the branch they occupied, without encountering the water at its base; though, on the removal of the glass, they regained their liberty with as much celerity as in the instances already recorded.

"'This experiment, which, from want of due precaution has misled so many distinguished naturalists, I have tried with several geometric spiders, and always with the same success."

Mr Blackwall, from subsequent experiments, says he is " confident in affirming, that in motionless air, spiders have not the power of darting their threads evcn through the space of half an inch." $\uparrow$ The fol-

* Jinu. Trans., vol. xv. p. 456.

† Mag. Nat. Ilist., vol. ii. p. 397. 
lowing details are given in confirmation of this opinion. Mr Blackwall observed, the 1st Oct., 1826, a little before noon, with the sun shining brightly, no wind stirring, and the thermometer in the shade ranging from $55^{\circ} .5$ to $64^{\circ}$, a profusion of shining lines crossing each other at every angle, forming a confused net-work, covering the fields and hedges, and thickly coating his feet and ankles, as he walked across a pasture. He was more struck with the phenomenon, because on the previous day a strong gale of wind had blown from the south, and as gossamer is only seen in calm weather, it must have been all produced within a very short time.

"What more particularly arrested my attention," says Mr Blackwall, "was the ascent of an amazing quantity of webs, of an irregular, complicated structure, resembling ravelled silk of the finest quality, and clearest white; they were of various shapes and dimensions, some of the largest measuring upwards of a yard in length, and several inches in breadth in the widest part; while others were almost as broad as long, presenting an area of a few square inches only.

"6 These webs, it was quickly perceived, were not formed in the air, as is generally believed, but at the earth's surface. The lines of which they were composed, being brought into contact by the mechanical action of gentle airs, adhered together, till, by continual additions, they were accumulated into flakes or masses of considerable magnitude, on which the ascending current, occasioned by the rarefaction of the air contiguous to the heated ground, acted with so much force as to separate them from the objects to which they were attached, raising them in the atmosphere to a perpendicular height of at least several hundred feet. I collected a number of these webs about mid-day, as they rose; and again in the 
afternoon, when the upward current had ceased, and they were falling: but scarcely one in twenty contained a spider; though, on minute inspection, I found small winged insects, chiefly aphides, entangled in most of them.

"From contemplating this unusual display of gossamer, my thoughts were naturally directed to the animals which produced it, and the countless myriads in which they swarmed almost created as much surprise as the singular occupation that engrossed them. Apparently actuated by the same impulse, all were intent upon traversing the regions of air; accordingly, after gaining the summits of various objects, as blades of grass, stubble, rails, gates, \&c., by the slow and laborious process of climbing, they raised themselves still higher by straightening their limbs; and elevating the abdomen, by bringing it from the usual horizontal position, into one almost perpendicular, they emitted from their spinning apparatus, a small quantity of the glutinous secretion with which they construct their webs. This viscous substance being drawn out by the ascending current of rarefied air into fine lines several feet in length, was carried upward, until the spiders, feeling themselves acted upon with sufficient force in that direction, quitted their hold of the objects on which they stood, and commenced their journey by mounting aloft.

"Whenever the lines became inadequate to the purpose for which they were intended, by adhering to any fixed body, they were immediately detached from the spinners, and so converted into terrestrial gossamer, by means of the last pair of legs, and the proceedings just described were repented; which plainly proves that these operations result from a strong desire felt by the insects to effect an ascent."

* Linn. Trans., vol. xv. p. 453.

VOL. IV. 
6. Without going into the particulars of what agrees or disagrees in the above experiments with our own observations, we shall give a brief account of what we have actually seen in our researches.* So far as we have determined, then, all the various species of spiders, how different soever the form of their webs may be, proceed in the circumstance of shooting their lines precisely alike; but those which we have found the most manageable in experimenting, are the small gossamer spider (Aranea obtectrix, Bechstein), known by its shining blackish-brown body and reddish-brown semi-transparent legs; but particularly the long-bodied spider (Tetragnatha extensa, LATR.), which varies in colour from green to brownish or grey-but has always a black line along the belly, with a silvery white or yellowish one on each side. The latter is chiefly recommended by being a very industrious and persevering spinner, while its movements are easily seen, from the long cylindrical form of its body and the length of its legs.

We placed the above two species with five or six others, including the garden, the domestic, and the labyrinthic spiders, in empty wine-glasses set in teasaucers filled with water to prevent their escape. When they discovered, by repeated descents from the brims of the glasses that they were thus surrounded by a wet ditch, they all set themselves to the task of throwing their silken bridges across. For this purpose they first endeavoured to ascertain in what direction the wind blew, or rather (as the experiment was made in our study) which way any current of air set,-by elevating their arms as we have seen sailors do in a dead calm. But, as it may prove more interesting to keep to one individual, we 
shall first watch the proceedings of the gossamer spider.

Finding no current of air on any quarter of the brim of the glass, it seemed to give up all hopes of constructing its bridge of escape, and placed itself in the attitude of repose; but no sooner did we produce a stream of air, by blowing gently towards its position, than, fixing a thread to the glass, and laying hold of it with one of its feet, by way of security, it placed its body in a vertical position, with its spinnerets extended outwards; and inmediately we had the pleasure of seeing a th:ead streaming out from them several feet in length, on which the little aëronaut sprung up into the air. We were convinced, from what we thus observed, that it was the double or bend of the thread which was blown into the air; and we assigned as a reason for her previously attaching and drawing out a thread from the glass, the wish to give the wind a point d'appui-something upon which it might have a purchase, as a mechanic would say of a lever. The bend of the thread, then, on this view of the matter, would be carried out by the wind,-would form the point of impulsion, - and, of course, the escape bridge would be an ordinary line doubled.

Such was our conclusion, which was strongly corroborated by what we subsequently found said by II. Latreille-than whom no higher authority could be given. "When the animal," says he, "desires to cross a brook, she fixes to a tree or some other object, one of the ends of her first threads, in order that the wind or a current of air may carry the other end beyond the obstacle;" $*$ and as one end is always attached to the spinnerets, he must mean that the double of the thread flies off.

* __ "L'un des bouts de ces premiers fils, afin que le vent ou un courant d'air pousse l'autre extremite de l'un d'eux au de là de l'obstacle."-Dict. Classique d'Hist. Nat., vol. i. p. 510. 
In order to ascertain the fact, and put an end to all doubts, we watched with great care and minuteness, the proceedings of the long-bodied spider above mentioned, by producing a stream of air in the same manner, as it perambulated the brim of the glass. It immediately, as the other had done, attached a thread and raised its body perpendicularly, like a tumbler standing on his hands with his head downwards; but we looked in vain for this thread bending, as we had at first supposed, and going off double. Instead of this it remained tight, while another thread, or what appeared to be so, streamed off from the spinners, sometimes in a line, and sometimes at a considerable angle, with the first, according to the current of the air, - the first thread, extended from the glass to the spinnerets, remaining all the while tight drawn in a right line. It further appeared to us, that the first thread proceeded from the pair of spinnerets nearest the head, while the floating thread came from the outer pair,-though it is possible in such minute objects we may have been deceived. That the first was continuous with the second, without any perceptible joining, we ascertained in numerous instances, by catching the floating line and pulling it tight, in which case the spider glides along without attaching another line to the glass; but if she have to coil up the floating line to tighten it, as usually happens, she gathers it into a packet and glues the two ends tight together. Her body, while the floating line streamed out, remained quite motionless, but we distinctly saw the spinnerets not only projected, as is always done when a spider spins, but moved in the same way as an infant moves its lips when sucking. We cannot doubt, therefore, that this motion is intended to emit (if eject or project be deemed too strong words) the liquid material of the thread; at the same time, we are quite certain that it cannot 
throw out a single inch of thread without the aid of a current of air. A long-bodied spider will thus throw out in succession as many threads as we please, by simply blowing towards it; but not one where there is no current, as under a bell-glass, where it may be kept till it die, without being able to construct a bridge over water of an inch long. We never observed more than one floating thread produced at the same time; though other observers mention several.

The probable commencement, we think, of the floating line, is by the emission of little globules of the glutinous material to the points of the spinnerules - perhaps it may be dropped from them, if not ejected, and the globules being carried off by the current of air, drawn out into a thread. But we give this as only a conjecture, for we could not bring a glass of sufficient power to bear upon the spinnerules at the commencement of the floating line.

In subsequent experiments we found, that it was not indispensable for the spider to rest upon a solid body when producing a line, as she can do so while she is suspended in the air by another line. When the current of air also is strong, she will sometimes commit herself to it by swinging from the end of the line. We have even remarked this when there was scarcely a breath of air.

We tried another experiment. We pressed pretty firmly upon the base of the spinnerets, so as not to injure the spider, blowing obliquely over them; but no floating line appeared. We then touched them with a pencil and drew out several lines an inch or two in length, upon which we blew in order to extend them, but in this also we were unsuccessful, as they did not lengthen more than a quarter of an inch. We next traced out the reservoirs of a gardenspider (Epeira diadema), and immediately taking a yoL, IV. 
drop of the matter from one of them on the point of a fine needle, we directed upon it a strong current of air, and succeeded in blowing out a thick yellow line as we might have done with gum-water, of about an inch and a half long.

When we observed our long-bodied spider eager to throw a line by raising up its body, we brought within three inches of its spinnerets an excited stick of sealing-wax, of which it took no notice, nor did any thread extend to it, not even when brought almost to touch the spinnerets. We had the same want of success with an excited glass rod; and indeed we had not anticipated any other result, as we have never observed that these either attract or repel the floating threads, as Mr Murray has seen them do; nor have we ever seen the end of a floating thread separated into its component threadlets and diverging like a brush, as he and Mr Bowman describe.

\section{Nests, Webs, and Nets of Spiners.}

The neatest, though the smallest spider's nest, which we have seen, was constructed in the chink of a garden post, which we had cut out the previous summer in getting at the cells of a carpenter-bee. The architect was one of the larger hunting-spiders erroneously said by some naturalists to be incapable of spinning. The nest in question was about two inches high, composed of a very close satin-like texture. There were two parallel chambers placed perpendicularly, in which position also the inhabitant reposed there during the day, going, as we presume, only abroad to prey during the night. But the most remarkable circumstance was, that the openings (two above and two below) were so elastic, that they shut almost as closely as the boat cocoon of the Tortrix chlorana (see page 322). We observed this spider for several months, but at last it disappeared, and we 
took the nest out, under the notion that it might contain eggs; but we found none, and therefore conclude that it was only used as a day retreat.* The account which Evelyn has given of these hunting-spiders is so interesting, that we must transcribe it.

"Of all sorts of insects," says, he, "there is none has afforded me more divertisement than the venatores (bunters), which are a sort of lupi (wolves) that have their dens in rugged walls and crevices of our houses; a small brown and delicately-spotted kind of spiders, whose hinder legs are longer than the rest. Such I did frequently observe at Rome, which, espying a fly at three or four yards distance, upon the balcony where I stood, would not make directly to her, but crawl under the rail, till being arrived to the antipodes, would steal up, seldom missing its aim; but if it chanced to want any thing of being perfectly opposite, would, at first peep, immediately slide down again,--till, taking better notice, it would come the next time exactly upon the fly's back: but if this happened not to be within a competent leap, then would this insect move so softly, as the very shadow of the gnomon seemed not to be more imperceptible, unless the fly moved; and then would the spider move also in the same proportion, keeping that just time with her motion, as if the same soul had animated both these little bodies; and whether it were forwards, backwards, or to either side, without at all turning her body, like a well managed horse: but if the capricious fly took wing and pitched upon another place behind our huntress, then would the spider whirl its body so nimbly about, as nothing could be imagined more swift: by which means she always kept the head towards her prey, though to appearance, as immoveable as if it had been a nail 
driven into the wood, till by that indiscernible progress (being arrived within the sphere of her reach) she made a fatal leap swift as lightning, upon the fly, catching him in the pole, where she never quitted hold till her belly was full, and then carried the remainder home."

One feels a little sceptical, however, when he adds, "I have beheld them instructing their young ones how to hunt, which they would sometimes discipline for not well observing; but when any of the old ones did (as sometimes) miss a leap, they would run out of the field and hide themselves in their crannies, as ashamed, and haply not to be secn abroad for four or five hours after; for so long have I watched the nature of this strange insect, the contemplation of whose so wonderful sagacity and address has amazed me; nor do I find in any chase whatsoever more cunning and stratagem observed. I have found some of these spiders in my garden, when the weather, towards spring, is very hot, but they are nothing so eager in hunting as in Italy."

We have only to add to this lively narrative, that the hunting spider, when he leaps, takes good care to provide against accidental falls by always swinging himself from a good strong cable of silk, as Swammerdam correctly states,,$\uparrow$ and which anybody may verify, as one of the small hunters (Salticus scenicus), known by having its back stripped with black and white like a zebra, is very conmon in Britain.

As a contrast to the little elastic satin nest of the hunter, we may mention the largest with which we are acquainted,--that of the labyrinthic spider (Agelena labyrinthica, WALCKEnAER). Our readers must often have seen this nest spread out like a broad sheet in hedges, furze, and other low bushes, and

* Evelyn's Travels in Italy.

+ Dog's of Nature, part i. page 24. 
sometimes on the ground. The middle of this sheet, which is of a close texture, is swung like a sailor's hammock, by silken ropes extended all around to the higher branches; but the whole curves upwards and backwards, sloping down to a long funnel-shaped gallery which is nearly horizontal at the entrance, but soon winds obliquely till it becomes quite perpendicular. This curved gallery is about a quarter of an inch in diameter, is much more closely woven than the sheet part of the web, and sometimes descends into a hole in the ground, though oftener into a group of crowded twigs, or a tuft of grass. Here the spider dwells secure, frequently resting with her legs extended from the entrance of the gallery, ready to spring out upon whatever insect may fall into her sheet net. She herself can only be caught by getting behind her and forcing her out into the web; but though we have often endeavoured to make her construct a nest under our eye, we have been as unsuccessful as in similar experiments with the common house spider (Aranea domestica).*

'The house spider's proceedings were long ago described by Homberg, and the account has been copied, as usual, by almost every subsequent writer. Goldsmith has, indeed, given some strange mis-statements from his own observations, and Bingley has added the original remark, that after fixing its first thread, creeping along the wall and joining it as it proceeds, it " darts itself to the opposite side, where the other end is to be fastened!" $\dagger$ Homberg's spider took the more circuitous route of travelling to the opposite wall, carrying in one of the claws the end of the thread previously fixed, lest it should stick in the wrong place. This we believe to be the correct statement, for as the web is always horizontal, it would

* J. R.

+ Animal Biography, iii. 470-1. 
seldom answer to commit a floating thread to the wind, as is done by other species. Homberg's spider, after stretching as many lines by way of warp, as it deemed sufficient between the two walls of the corner which it had chosen, proceeded to cross this in the way our weavers do in adding the woof, with this difference, that the spider's threads were only laid on and not interlaced.* The domestic spiders, however, in these modern days, must have forgot this mode of weaving, for none of their webs will be found to be thus regularly constructed.

The geometric, or net-working spiders (Tendeuses, LATR.), are as well known in most districts as any of the preceding; almost every bush and tree in the gardens and hedge rows having one or more of their nets stretched out in a vertical position between adjacent branches. The common garden spider (Epeira diadema), and the long-bodied spider (Tetragnatha extensa), are the best known of this order.

The chief care of a spider of this sort is, to form a cable of sufficient strength to bear the net she means to hang upon it; and, after throwing out a floating line as above described, when it catches properly she doubles and redoubles it with additional threads. On trying its strength she is not contented with the test of pulling it with her legs, but drops herself down sereral feet from various points of it, as we have often seen, swinging and bobbing with the whole weight of her body. She proceeds in a similar manner with the rest of the frame-work of her wheel-shaped net; and it may be remarked that some of the ends of these lines are not simple, but in form of a $\mathbf{Y}$, giving her the additional security of two attachments instead of one.

In constructing the body of the net, the most re-

* Mem. de l'Acad des Sciences pour 1707, p 339. 
suspensory lincs, - a circumstance alleged to be proved by the former appearing under the microscope studded with globules of gum.* We have not been able to verify this distinction, having seen the suspensory lines as often studded in this manner as those in the centre. $\uparrow$

\section{Mason-Spiders.}

A no less wonderful structure is composed by a sort of spiders, natives of the tropics and the South of Europe, which have been justly called masonspiders by M. Latreille. One of these (Mygale nidulans, Wa Lccks.) found in the West Indies, "digs a hole in the earth obliquely downwards, about three inches in length, and one in diameter. This cavity she lines with a tough thick web, which, when taken out, resembles a leathern purse; but what is most curious, this house has a door with hinges, like the operculum of some sea-shells, and herself and family, who tenant this nest, open and shut the door whenever they pass and repass. This history was told me," says Darwin, " and the nest, with its door, shewn me by the late Dr Butt, of Bath, who was some years physician in Jamaica."

The nest of a mason-spider, similar to this, has been obligingly put into our hands by Mr Riddle, of Blackheath. It came from the West Indies, and is probably that of Latreille's clay-kneader (Mygale cratiens), and one of the smallest of the genus. It is composed of very hard argillaceous clay, deeply tinged with brown oxide of iron. It is in form of a tube, about one inch in diameter, between six and seven inches long, and slightly bent towards the lower extrenity - appearing to have been mined into the clay rather than built. The interior of the

* Kirby and Spence, Intr. i. 149. + J. R.

+ Darwin's Zoonomia, i. 253. 8vo ed. 
tube is lined with an uniform tapestry of silken web, of an orange-white colour, with a texture intermediate between Indian paper and very fine glove-leather. But the most wonderful part of this nest is its entrance, which we look upon as the perfection of insect architecture. A circular door, about the size of a crown piece, slightly concave on the outside and convex within, is formed of more than a dozen layers of the same web which lines the interior, closely laid upon one another, and shaped so that the inner layers are the broadest, the outer being gradually less in diameter, except towards the hinge, which is about an inch long; and in consequence of all the layers being united there, and prolonged into the tube, it becomes the thickest and strongest part of the structure. The elasticity of the materials, also, gives to this hinge the remarkable peculiarity of acting like a spring, and shutting the door of the nest spontaneously. It is, besides, made to fit so accurately to the aperture, which is composed of similar concentric layers of web, that it is almost impossible to distinguish the joining by the most careful inspection. To gratify curiosity, the door has been opened and shut hundreds of times, without in the least destroying the power of the spring. When the door is shut, it resembles some of the lichens (Lecidca), or the leathery fungi, such as Polyporus versicolor, (MIcHEL1,) or, nearer still, the upper valve of a young oyster shell. The whole nest being of a blackishbrown colour, it must be very difficult to discover.*

Another mason-spider (Mygale camentaria, LATr.) found in the South of France, usually selects for her nest a place bare of grass, sloping in such a manner as to carry off the water, and of a firm soil, without rocks or small stones. She digs a gallery a foot or two

$$
\text { * J. R. }
$$

VOL. IV, 
in depth, and of a diameter (equal throughout) sufficient to admit of her easily passing. She lines this with a tapestry of silk, glued to the walls. The door, which is circular, is constructed of many layers of earth kneaded, and bound together with slk. Externally, it is flat and rough, corresponding to the earth around the entrance, for the purpose, no doubt, of concealment: ont the inside it is convex, and tapestried thickly with a web of fine silk. The threads of this door-tapestry are prolonged, and strongly attached to the upper side of the entrance, forming an excellent hinge, which, when pushed open by the spider, shuts again by its own weight, without the
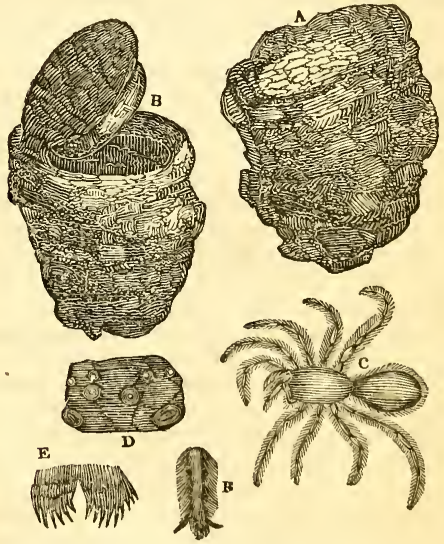

Nist of the Mrtson-Spidcr.

A. The nest shut. B. Tlte nest open. C. The spider, mygale canentarin, D. The eyes magnified. E, F. Parts of the foot and claw magnified. 
aid of spring hinges. When the spider is at home, and her door forcibly opened by an intruder, she pulls it strongly inwards, and even when half-opened often snatches it out of the hand; but when she is foiled in this, she retreats to the bottom of her den, as her last resource.*

Rossi ascertained that the female of an allied species (Mygale sauvagesii, Latr.), found in Corsica, lived in one of these nests with a numerous posterity. $\mathrm{He}$ destroyed one of these doors to observe whether a new one would be made, which it was: but it was fixed immoveably, without a hinge; the spider, no doubt, fortifying herself in this manner till she thought she might re-open it without danger. $\dagger$

"The Rev Revett Shepherd has often noticed in the fen ditches of Norfolk, a very large spider (the species not yet determined) which actually forms a raft for the purpose of obtaining its prey with more facility. Keeping its station upon a ball of weeds about three inches in diameter, probably held together by slight silken cords, it is wafted along the surface of the water upon this floating island, which it quits the noment it sees a drowning insect. The booty thus seized it devours at leisure upon its raft, under which it retires when alarmed by any danger."'

Among our native spiders there are several beside this one, which, not contented with a web like the rest of their congeners, take advantage of other materials to construct cells where, " hush'd in grim repose," they " expect their insect prey." The most simple of those spider-cells is constructed

* Mem. Soc. d'Hist. Nat. de Paris, An. vii.

+ lbid. p. 125, and Latreille, Hist. Nat. G nér. viii. p. 163. ‡ Kirby and Spence, Intr. i. 425. 
by a longish-bodied spider (Aranea holosericea, Linn.), which is a little larger than the common lunting spider. It rolls up a leaf of the lilac or poplar, precisely in the same manner as is done by the leaf-rolling caterpillars, upon whose cells it sometimes seizes to save itself trouble, having first expelled, or perhaps devoured, the rightful owner. The spider, however, is not satisfied with the tapestry of the caterillar, and always weares a fresh set of her own, much more close and substantial.

Another spider common in woods and copses (Epeira quadrala?) weaves together a great number of leaves to form a dwelling for herself, and in front of it she spreads her toils for entrapping the unwary insects which stray thither. These, as soon as caught, are dragged into her den, and stored up for a time of scarcity. Here also her eggs are deposited and hatched in safety. When the cold weather approaches, and the leaves of her edifice wither, she abandons it for the more secure shelter of a hollow tree, where she soon dies; but the continuation of the species depends upon eggs, deposited in the nest before winter, and remaining to be hatched with the warmth of the ensuing summer.

The spider's den of united leaves, however, which has just been described, is not always useless when withered and deserted; for the dormouse, or the harvest mouse (Mus mesorius), we are not ccrtain which, usually selects it as a ready-made roof for its nest of dried grass. That those old spiders' dens are not accidentally chosen by the mouse, appears from the fact, that out of about a dozen mouse-nests of this sort found during winter in a copse betwecn Lewisham and Bromley, Kent, every second or third one was furnished with such a roof.* 


\section{Diving Water-Sipider.}

That spiders may be able to breathe under water; we can well understand from their breathing like amphibious reptiles by means of gills; but there is an aquatic spider (Argyroneta aquatica, WALCKENAER) which is not contented, as a frog would be, with the air furnished by the water, but actually carries down a supply of air from the atmosphere to her subaqueous nest. This spider does not like stagnant water, but prefers slow-running streams and ditches where she may often be seen, in the vicinity of London and elsewhere, living in her diving-bell, which shines through the water like a little globe of silver: her singular economy was first, we believe, described by Clerck,* L. M. de Lignac, $\nmid$ and De Geer.

"The shining appearance," says Clerck, " proceeds either from an inflated globule surrounding the abdomen, or from the space between the body and the water. The spider when wishing to inhale the air, rises to the surface with its body still submersed, and only the part containing the spinneret rising just to the surface, when it briskly opens and moves its four teats. A deep cone of hair keeps the water from approaching or wetting the abdomen. It comes up for air about four times an hour or oftener, though I have good reason to suppose it can continue without it for several days together.

"I found in the middle of May one male and ten females, which I put into a glass filled with water, where they lived together very quietly for eight days. I put some duck weed (Lemna) into the glass to afford them shelter, and the females began to strètch diagonal threads in a confused manner from it to the

* Aranei Suecici, Stockholm, 1757.

† Mem. des Araign. Aquat. 12mo. Paris, 1799. ror.. Ir. 
sides of the glass about half way down. Each of the females afterwards fixed a close bag to the edge of the glass, from which the water was expelled by the air fiom the spinneret, and thus a cell was formed capable of containing the whole animal. Here they remained quietly, with their abdomens in their cells, and their bodies still plunged in the water; and in a short time brimstone-coloured bags of eggs appeared in each cell, filling it about a fourth part. On the 7th of July several young ones swam out fiom one of the bags:- all this time the old ones had nothing to eat, and yet they never attacked one another as other spiders would have been apt to do."

"These spiders," says de Geer, "spin in the water a cell of strong, closely woven, white silk in the form of half the shell of a pigeon's egg, or like a diving-bell. This is sometimes left partly above water, but at others is entirely submersed, and is always attached to the objects near it by a great number of irregular threads. It is closed all round, but has a large opening below, which, however, I found closed on the 15 th of December, and the spider living quietly within, with her head downwards. 1 made a rent in this cell and expelled the air, upon which the spider came out; yet though she appeared to have been laid up for three months in her winter quarters, she greedily seized upon an insect and sucked it. I also found that the male as well as the female constructs a similar subaqueous cell, and during summer no less than in winter." $†$

\section{Creanliness of Spiders.}

When we look at the viscid material with which spiders construct their lines and webs, and at the

* Clerck, Aranei Suecici, Cap. viii.

† De Geer, Mem. des Insectes, vii. 312. 
rough, hairy covering (with a few exceptions) of their bodies, we might conclude that they would be always stuck over with fragments of the minute fibres which they produce. This, indeed, must often happen, did they not take careful precautions to avoid it; for we have observed that they seldom, if ever, leave a thread to float at random, except when they wish to form a bridge. When a spider drops along a line, for instance, in order to ascertain the strength of her web, or the nature of the place below her, she invariably, when she re-ascends, coils it up into a little ball, and throws it away. Her claws are admirably adapted for this purpose, as well as for walking along the lines, as may be readily seen by a magnifying glass.

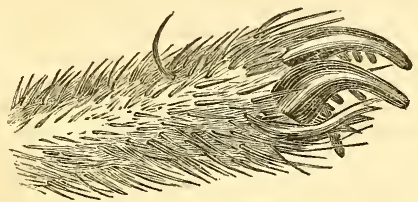

Triplc-clawed foot of a Spiler, magnificd.

There are three claws, one of which acts as a thumb, the others being toothed like a comb, for gliding along the lines. This structure, however, unfits it to walk, as flies can do, upon any upright polished surface like glass; although the contrary* is erroneously asserted by the Abbe de la Pluche. Before she can do so, she is obliged to construct a ladder of ropes, as Mr. Blackwall remarks, $\uparrow$ by elevating her spinneret as high as she can, and laying

* Spectâcle de la Nature, i. 58. + Linn. Trans. vol. xv. 
down a step upon which she stands to form a second; and so on, as any one may try by placing a spider at the bottom of a very clean wine glass.

The hairs of the legs, however, are always catching bits of web and particles of dust; but these are not suffered to remain long. Most people may have remarked that the house-fly is ever and anon brushing its feet upon one another to rub off the dust, though we have not seen it remarked in authors, that spiders are equally assiduous in keeping themselves clean They have, besides, a more efficient instrument than the fly, in their mandibles or jaws, which, like their claws, are furnished with teeth; and a spider which appears to a careless observer as resting idly, in nine cases out of ten, will be found slowly combing her legs with her mandibles, beginning as high as possible on the thigh, and passing down to the claws. The flue which she thus combs off is regularly tossed away.

With respect to the house-spider ( $A$. domestica), we are told in books, that she "from time to time clears away the dust from her web, and sweeps the whole by giving it a shake with her paw so nicely proportioning the force of her blow, that she never breaks any thing." " That spiders may be seen shaking their webs in this manner, we readily admit; though it is not, we imagine, to clear them of dust, but to ascertain whether they are suficiently sound and strong.

We recently witnessed a more laborious process of cleaning a web than merely shaking it. On coming down the Maine by the steam-boat from Frankfort, in August 18\%9, we observed the geometric-net of a conic-spider (Epeira conica, WALcK.) on the framework of the deck, and as it was covered with flakes

* Spectâcle de la Nature, i. p. 61. 
of soot fiom the smoke of the engine, we were surprised to see a spider at work on it; for, in order to be useful, this sort of net must be clean. Upon observing it a little closely, however, we perceived that she was not constructing a net, but dressing up an old one; though not, we must think, to save trouble so much as an expenditure of material. Some of the lines she dexterously stripped of the flakes of soot adhering to them; but in the greater number finding that she could not get them sufficiently clean, she broke them quite off, bundled them up, and tossed them over. IVe counted five of these packets of rubbish which she thus threw away, though there must have been many more, as it was some time before we discovered the mancuvre, the packets being so small as not to be readily perceived, except when placed between the eye and the light. When she has cleared off all the sooted lines, she began to replace them in the usual way; but the arrival of the boat at Mentz put an end to our observations,** 


\section{Chapter XIX.}

Structures of Gall-Flies and Aphides.

MANY of the processes which we have detailed bear some resemblance to our own operations of building with materials cemented together; but we shall now turn our attention to a class of insectarchitects, who cannot, so far as we know, be matched in prospective skill, by any of the higher orders of animals. We refer to the numerous family which have received the name of gall-flies, - a family which, as yet is very imperfectly understood, their economy being no less difficult to trace, than their species is to arrange in the established systems of classification.

One of the most simple and very common in-
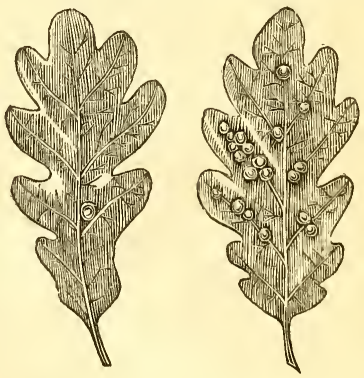

Small berry-shaped galls of the oak leaf, produced by Cynips Qucreus folii? 
stances of the nests constructed by gall-insects, may be found in abundance during the summer, on the leaves of the rose-tree, the oak, the poplar, the willow (Salix viminalis,) and many other trees, in the globular form of a berry, about the size of a currant, and usually of a green colour, tinged with red, like a ripe Alban or Baltinore apple.

When this pseudo apple in miniature is cut into, it is found to be fresh, firm, juicy, and hollow in the centre, where there is either an egg or a grub safely lodged, and protected from all ordinary accidents. Within this hollow ball the egg is hatched, and the grub feeds securely on its substance, till it prepares for its winter slcep, before changing into a gall-fly (Cynips), in the ensuing summer. There is a mystery as to the manner in which this gall-fly contrives to produce the hollow miniature-apples, each enclosing one of her eggs; and the doubts attendant upon the subject cannot, so far as our present knowledge extends, be solved, except by plausible conjecture. Our earlier naturalists were of opinion that it was the grub which produced the galls, by eating when newly hatched, through the cuticle of the leaf, and remaining till the juices flowing from the wound enveloped it, and acquired consistence by exposure to the air. This opinion, however, plausible as it appeared to be, was at once disproved by finding unhatched eggs on opening the galls.

There can be no doubt, indeed, that the mother gallfly making a hole in the plant for the purpose of depositing her eggs. She is furnished with an admirable ovipositor for that express purpose, and Swarnmerdam actually saw a gall-fly thus depositing her eggs. In some of these insects the ovipositor is conspicuously long, even when the insect is at rest; but in others, not above a line or two of it is visible, till the belly of the insect be gently 
pressed. When this is done to the fly that produces the currant-gall of the oak, the ovipositor may be seen issuing from a sheath in form of a small curved needle, of a chesnut-brown colour, and of a horny substance, and three times as long as it at first appeared.

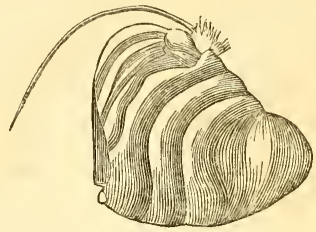

Ovipositor of gall-fly greatly magnified.

What is most remarkable in this ovipositor is, that it is much longer than the whole body of the insect, in whose belly it is lodged in a sheath, and from its horny nature, it cannot be either shortened or lengthened. It is on this account that it is bent into the same curve as the body of the insect. The mechanism by which this is effected is similar to that of the tongue of a woodpecker (picus), which, though rather short, can be darted out far beyond the beak, by means of the hyoid-bone* being thin and rolled up like the spring of a watch. The base of the ovipositor of the gall-fly is, in a similar way, placed near the anus, runs along the curvature of the back, makes a turn at the breast, and then, following the curve of the belly, appears again near where it originates. IVe copy from $\mathbf{R}$ aumur his accurate sketch of this remarkable structure.

* A forked bone at the root of the tongue. 


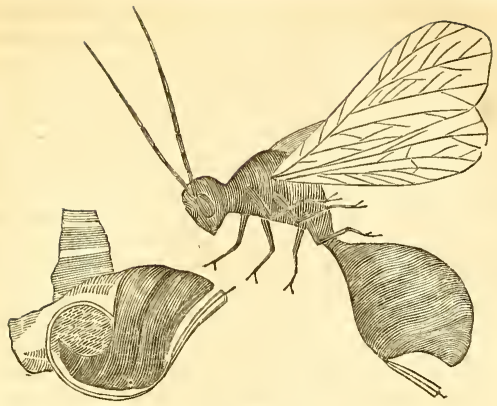

Gall-fiy, and mechanism of oripositor, greatly magnified.

With this instrument the mother gall-fly pierces the part of a plant which she selects, and, according to our older naturalists, " ejects into the cavity a drop of her corroding liquor, and immediately lays an egg or more there; the circulation of the sap being thus interrupted, and thrown, by the poison, into a fermentation that burns the contiguous parts, and changes the natural colour. The sap, turned from its proper channel, extravasates and flows round the eggs while its surface is dried by the external air, and hardens into a vaulted form." Kirby and Spence tell us, that the parent fly introduces lier egg " into a puncture made by. her curious spiral sting, and in a few hours it becomes surrounded with a fleshy chamber." $\dagger$ M. Virey says, the gall tubercle is produced by irritation, in the same way as an inflamed tumor

* Spectâcle de la Nature, i. 119.

$\dagger$ Introd., ii. 449.

roL. IY. 
in an animal body, by the swelling of the cellular tissue and the flow of liquid matter, which changes the organization, and alters the natural external form.* This seems to be the received doctrine at present in France. $\dagger$

Sprengel, speaking of the rose-willow, says, the insect in spring deposits its eggs in the leaf buds. "The new stimulus attracts the sap,-the type of the part becomes changed, and from the prevailing acidity of the animal juice, it happens, that in the rose and stock-shaped leaves which are pushed out, a red instead of a green colour is evolved." I

Without pretending positively to state facts which are, perhaps, beyond human penetration, we may view the process in a rather different light. $§$ Following the analogy of what is lnown to occur in the case of the saw-flies (see page 156), after the gall-fly has made a puncture and pushed her egg into the hole, we may suppose that she covers it over with some adhesive gluten or gum, or the egg itself, as is usual among moths, \&c., may be coated over with such a gluten. In either of these two cases, the gluten will prevent the sap that flows through the puncture from being scattered over the leaf and wasted; and the sap, being thus confined to the space occupied by the eggs, will expand and force ontwards the pellicle of gluten that confines it, till becoming thickened by evaporation and exposure to the air, it at length shuts up the puncture, stops the further escape of the sap, and the process is completed. This explanation will completely account for the globular form of the galls alluded to; that is, supposing the egg of the

* Hist. des Mœurs et de l'Instinct. vol. ii.

+ Entomologie par R. A. E. page 242. Paris, 1826 .

$¥$ Elements of the Philosophy of P'lants, Eng. Trans. p. 285. $\S$ J. R. 
gall-fly to be globular, and covered, or coated with a pellicle of gluten of uniform thickness, and consequently opposing uniform resistance, or rather uniform expansibility, to the sap pressing from within. It will also account for the remarkable uniformity in the size of the gall apples; for the punctures and the eggs being uniform in size, and the gluten by supposition, uniform in quantity, no more than the same quantity of sap can escape in such circumstances.

But though this explanation appears to be plausible, it is confessedly altogether conjectural; for nobody since Swammerdam, so far as we at present know, has ever detected a gall-fly in the act of depositing her eggs, and he did not attend to this circumstance. The indefatigable Réaumur, on one occasion, thought he would make sure of tracing the steps of the process in the case of the gall-fly, which produces the bedeguar* on the wild-rose tree, and to which we shall presently advert. His plan was to enclose in a box, in which a brood of flies had just been produced from a bedeguar, a living branch from a wild rose-tree; but, to his great disappointment, no eggs were laid, and no bedeguar formed. Upon further investigation, he discovered that the brood of flies produced from the bedeguar were not the genuine bedeguar insects at all, but one of the parasite ichneumons (Callimone Bedeguaris, STEPHENs, which had surreptitiously deposited their eggs there, in order to supply their young with the bedeguar grubs, all of which they appeared to have devoured. It may prove interesting to look into the remarkable structure of the bedeguar itself, which is very different from the globular galls above described.

* The gall of the rose is so called botanically. 


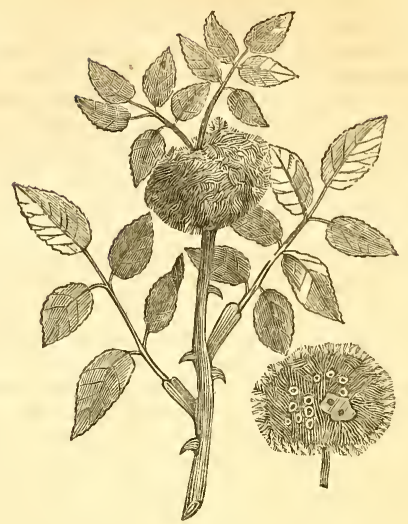

Bedeguar gall of the rose, produced by Cynips Rusa.

The gall-fly of the willow (Cynips viminalis) deposits, as we have just seen, only a single egg on one spot; but the bedeguar-insect lays a large cluster of eggs on the extremity of a growing branch of the wild rose-tree, making, probably, a proportionate number of punctures to procure materials for the future habitation of her young progeny. As in the former case also, each of these eggs becomes (as we may suppose) surrounded with the sap of the rose, enclosed in a pellicle of gluten. The gluten, however, of the bedeguar inseet is not, it would appear, sufficiently tenacious to confine the flowing sap within the dimensions of any of the little clustered globes containing the eggs, for it oozes out from numerous cracks or pores in the pellicle; which 
cracks or pores, however, are not large enough to admit a human hair. But this, so far from being a defect in the glutinous pellicle of the bedeguar fly, is, as we shall presently see, of great utility. The sap which issues from each of those pores, instead of being evaporated and lost, shoots out into a reddishcoloured, fibrous bristle.

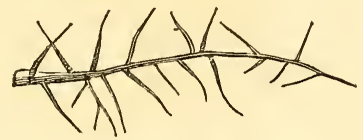

One of the bristles of the Bedeguar of the rose magnified.

It is about half an inch long, and, from the natural tendency of the sap of the rose tree to form prickles, these are all over studded with weak pricklets. The bedeguar, accordingly, when fully formed, has some resemblance, at a little distance, to a tuft of reddishbrown hair or moss, stuck upon the branch. Sometimes this tuft is as large as a small apple, and of a rounded, but irregular shape; at other times it is smaller, and in one instance mentioned by Réaumur, only a single egg liad been laid on a rose leaf, and consequently, only one tuft was produced. Each nember of the congeries is furnished with its own tuft of bristles, arising from the little hollow globe in which the egg or the grub is lodged.

The prospective wisdom of this curious structure is admirable. The bedeguar grubs live in their cells through the winter, and as their domicile is usually on one of the highest branches, it must be exposed to every severity of the weather. But the close, nonconducting, warm, mossy collection of bristles with which it is surrounded, forms for the soft, tender grubs a snug protection against the winter's cold, till,

vol IV. 
through the influence of the warmth of the succeeding summer, they undergo their final change into the winged state,-preparatory to which they eat their way with their sharp mandibles through the walls of their little cells, which are now so hard as to be cut with difficulty by a knife.*

Another structure, similar in principle, though different in appearance, is very common upon oak-trees, the termination of a branch being selected as best suited for the purpose. This structure is rather larger than a filbert, and is composed of concentric leaves diverging from the base, and expanding upwards, somewhat like an artichoke. Whether this

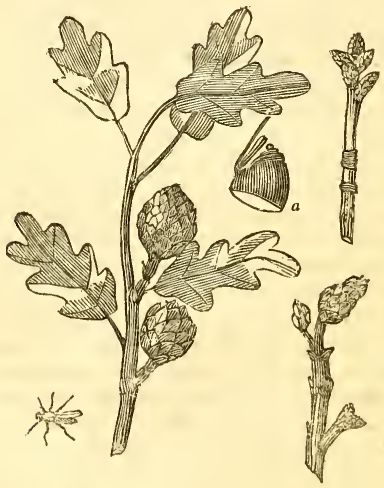

Artichoke Gull of the Oak-bud, with Gall-fy (Cynips Quercus gcmma), latural size, and its ovipositor $(a)$ magnified.

* J. R. 
leafy structure, is caused by a superinduced disease, as the French think, or by the form of the pores in the pellicle of gluten surrounding the eggs, or rather by the tendency of the exuding sap of the oak to form leaves, has not been ascertained; but that it is intended, as in the case of the bedeguar, to afford an efficient protection against the weather to the included eggs or grubs, there can be no doubt.

From the very nature of the process of forming willow-galls, bedeguar, and the artichoke of the oak, whatever theory be adopted, it will be obvious that their growth must be rapid; for the thickening of the exuded sap, which is quickly effected by evaporation, will soon obstruct and finally close the orifice of the puncture made by the parent insect. It is accordingly asserted by Reaumur and other observers, that all the species of galls soon reach their full growth.

A very minute reddish-coloured grub feeds upon dyer's broom (Genista), producing a sort of gall, frequently globular, but always studded with bristles, arising from the amorphus leaves. The stem of the shrub passes through this ball, which is composed of a great number of leaves, shorter and broader than natural, and each rolled into the form of a horn, the point of which ends in a bristle. In the interior we find a thick fleshy substance, serving to sustain the leaves, and also for the nourishment of the grubs, some of which are within and some between the leaves. They are in prodigious numbers,-hundreds being assembled in the same gall, and so minute as scarcely to be perceived without the aid of a rnagnifying glass. The bud of the plant attacked by those grubs, instead of forming a shoot, pushes out nothing but leaves, and these are all rolled and turned round the stem. Some shrubs 
have several of these galls, which are of various sizes, from that of a filbert to that of a walnut.

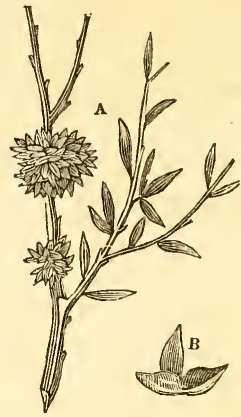

Leafy Gall of Dyer's Broom, produced by Cynips genista ? A. gall, natural size; 13 . a leafet magnified.

A similar but still more beautiful production is found upon one of the commonest of our indigenous willows (Salix purpurea), which takes the name of rose-willow, more probably from the circumstance than from the red colour of its twigs. The older botanists, not being aware of the cause of such excrescences, considered the plants so affected as distinct species; and old Gerard, accordingly, figures and describes the rose-willow as " not onlie making a gallant shew, but also yeelding a most cooling aire in the heat of summer, being set up in houses for decking the same." The production in question, however, is nothing more than the effect produced by a species of gall-fly (Cynips salicis) depositing its eggs in the terminal shoot of a twig, and, like the 
bedeguar and the oak artichoke, causing leaves to spring out, of a shape totally different from the other leaves of the tree, and arranged very much like the petals of a rose. Decandolle says it is found chiefly on the Salix helix, S. alba, and S. riparia.*

A production very like that of the rose-willow may be commonly met with on the young shoots of the hawthorn, the growth of the shoot affected being stopped, and a crowded bunch of leaves formed at the termination. These leaves, beside being smaller than natural, are studded with short bristly prickles, from the sap (we may suppose) of the hawthorn being prevented from rising into a fresh shoot, and thrown out of its usual course in the formation of the arms. These bristles appear indiscriminately on both sides of the leaves, some of which are bent inwards, while others diverge in their natural manner.

This is not caused by the egg or grub of a true gall-fly, but by the small white tapering grub of some dipterous insect, of which we have not ascertained the species, but which is, probably, a cecidomyia. Each terminal shoot is inhabited by a number of these-not lodged in cells, however, but burrowing indiscriminately among the half-withered brown leaves which occupy the centre of the production. $\dagger$

A more remarkable species of gall than any of the above, we discovered in June, 1829, on the twig of an oak in the grounds of Mr Perkins, at Lee, in Kent. When we first saw it, we imagined that the twig was beset with some species of the lanigerous aphides, similar to what is vulgarly called the American or white blight (aphis lanata;) but on closer examination we discarded this notion. The twig was indeed thickly beset with a white downy,

* Flore Franç. Disc. Pr liminaire. 


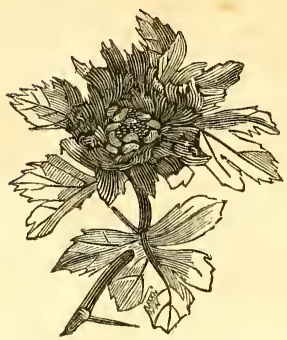

Seri-Gall of the Hawthorn, drawn from a specimen

or rather woolly, substance around the stem at the origin of the leaves, which did not appear to be affected in their growth, being well formed, healthy, and luxuriant. We could not doubt that the woolly substance was caused by some insect; but though we cut out a portion of it, we could not detect any egg or grub, and we therefore threw the branch into a drawer, intending to keep it as a specimen, whose history we might complete at some subsequent period.

A few weeks afterwards, on opening this drawer, we were surprised to see a brood of several dozens of a species of gall-fly (Cynips), similar in form and size to that whose eggs cause the bedeguar of the rose and differing only in being of a lighter colour, tending to a yellowish brown. We have since met with a figure and description of this gall in Swammerdam. We may remark that the above is not the first instance which has occurred in our researches, of gall insects outliving the withering of the branch or leaf which they obtain their nourishment. 


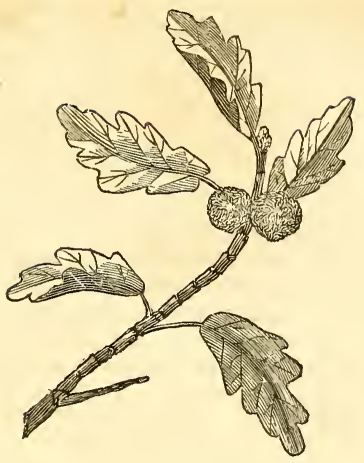

Woolly Gall of the Oak caused by a cynips, and drazun from a specimen.

The woolly substance on the branch of the oak which we have described was similarly constituted with the bedeguar of the rose, with this difference, that instead of the individual cells being diffused irregularly through the mass, they were all arranged at the off-goings of the leaf-stalks, each cell being surrounded with a covering of the vegetable wool, which the stimulus of the parent egg, or its gluten, had caused to grow, and from each cell a perfect fly had issued. We also remarked that there were several small groups of individual cells, each of which groups was contained in a species of calyx or cup of leaf-scales, as occurs also in the well known gall called the oak-apple. 
We were anxious to watch the proceedings of these flies in the deposition of their eggs, and the subsequent developments of the gall-growths; and endeavoured for that purpose to procure a small oak plant in a garden-pot; but we did not succeed in this: and though they alighted on rose and sweet-briar trees, which we placed in their way, we never observed that they deposited any eggs upon them. In a week or two the whole brood died, or disappeared.*

There are some galls, formed on low-growing plants, which are covered with down, hair, or wool, though by no means so copiously as the one which we have just described. Among the plants so affected are the germander speedwell, wild-thyme, groundivy, and others, to which we shall afterwards advert.

The well-known oak-apple is a very pretty example of the galls formed by insects; and this, when compared with other galls which form on the oak, shews the remarkable difference produced on the same plant by the punctures of insects of different species. The

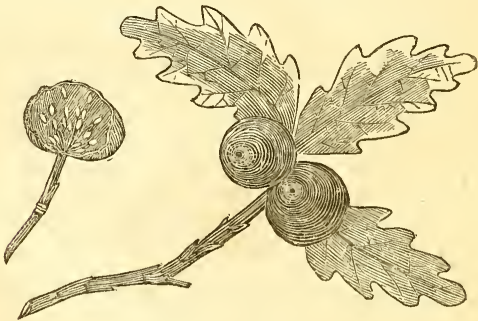

Oak-apple galls, onc boing cut open to shew the vessels running to granules.

* J. R. 
oak-apple is commonly as large as a walnut or small apple, rounded, but not quite spherical, the surface being irregularly depressed in various places. The skin is smooth, and tinged with red and yellow, like a ripe apple; and at the base there is, in the earlier part of the summer, a calyz or cup of five or six small brown scaly leaves; but these fall off as the season advances. If an oak-apple be cut transversely, there is brought into view a number of oval granules, each containing a grub, and embedded in a fruit-looking fleshy substance, having fibres running through it. As these fibres, however, run in the direction of the stem, they are best exhibited by a vertical section of the gall; and this also shows the remarkable peculiarity of each fibre terminating in one of the granules, like a footstalk, or rather like a vessel for carrying nourishment. R aumur, indeed, is of opinion that these fibres are the diverted nervures of the leaves, which would have sprung from the bud in which the gallfly had inserted her eggs, and actually do carry sapvessels throughout the substance of the gall.

Réaumur says the perfect insects (Cynips quercus) issued from his galls in June and the beginning of July, and were of a reddish-amber colour. We have procured insects, agreeing with Reaumur's description, from galls formed on the bark or wood of the

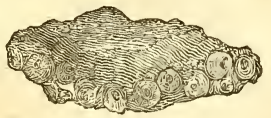

Root-Galls of the Oak, produced by Cynips quercus inferus? drawn from a specimen.

oak, at the line of junction between the root 'and the stem. Thesc galls are precisely similar in structure VOL. IV. 33 
to the oak-apple, and are probably formed at a season when the fly perceives, instinctively, that the buds of the young branches are unfit for the purpose of nidification.

There is another oak-gall, differing little in size and appearance from the oak-apple, but which is very different in structure, as instead of giving protection and nourishment to a number of grubs, it is only inhabited by one. This sort of gall, besides, is hard and woody on the outside, resembling a little wooden ball of a yellowish colour, but internally of a soft, spongy texture. The latter substance, however, incloses a small hard gall, which is the immediate residence of the included insect. Galls of this description are often found in clusters of from two to seven, near the extremity of a branch, not incorporated, however, but distinctly separate.

We have obtained a fly very similar to this from a very common gall, which is formed on the branches

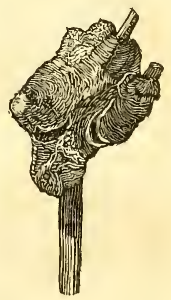

Woody-Gall on a Willow branch, drawn from a specimen.

of the willow. Like the one-celled galls just described, this is of a hard, ligneous structure, and forms an irregular protuberance, sometimes at the 
extremity, and sometimes on the body, of a branch. But instead of one, this has a considerable number of cells, irregularly distributed through its substance. The structure is somewhat spongy, but fibrous; and externally the bark is smoother than that of the branch upon which it grows.*

The currant-galls (as the French call them) of the oak are exactly similar, when formed on the leaves, to those which we have first described as produced on the leaves of the willow and other trees. But the name of currant-gall seems still more appropriate to an excrescence which grows on the catkins of the oak, giving them very much the appearance of a straggling bunch of currants or bird-cherries. The galls resemble currants which have fallen from the tree before being ripe. These galls do not seem to differ from those formed on the leaves of the oak; and are probably the production of the same insect,

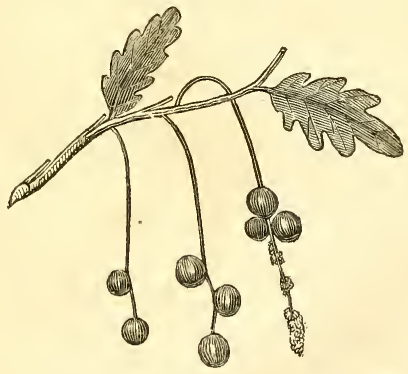

Currant-Gall of the catkins of the Oak, produced by Cynips quercus pedunculi?

* J. R. 
which selects the catkin in preference, by the same instinct that the oak-apple gall-fly, as we have seen, sometimes deposits its eggs in the bark of the oak near the root.

The gall of the oak, which forms an important dye-stuff, and is used in making writing-ink, is also produced by a Cynips, and has been described in the Library of Entertaining Knovledge, (Vegetable Substances, p. 16.) The employment of the Cynips psenes for ripening figs is described in the same volume, p. 244 .

\section{Gall of a Hawtiorn Weevil.}

In May, 1829, we found on a hawthorn at Lee, in Kent, the leaves at the extremity of a branch neatly folded up in a bundle, but not quite so closely as is usual in the case of leaf-rolling caterpillars. On opening them up, there was no caterpillar to be seen, the centre being occupied with a roundish, brown-coloured, woody substance, similar to some excrescences made by gall insects (Cynips). Had we been aware of its real nature, we should have put it immediately under a glass or in a box, till the contained insect had developed itself; but instead of this, we opened the ball, where we found a small yellowish grub coiled up, and feeding on the exuding juices of the tree. As we could not replace the grub in its cell, part of the walls of which we had unfortunately broken, we put it in a small pasteboard box with a fresh shoot of hawthorn, expecting that it might construct a fresh cell. This, however, it was probably incompetent to perform: it did not at least make the attempt, and neither did it seem to feed on the fresh branch, keeping in preference to the ruins of its former cell. To our great surprise, although it was thus exposed to the air, and deprived of a considerable portion of its nourishment, both from the 
part of the cell having been broken off, and from the juices of the branch having been dried up, the insect went through its regular changes, and appeared in the form of a small greyish-brown beetle of the weevil

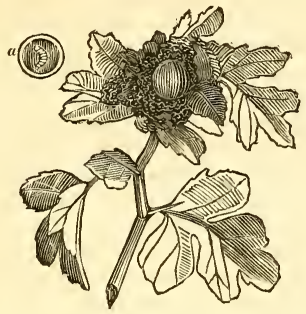

Gall of a Hawthorn Weevil, drawn from specimen. $a$. Opened to show the grub.

family. The most remarkable circumstance in the case in question, was the apparent inability of the grub to construct a fresh cell after the first was injured,-proving, we think, beyond a doubt, that it is the puncture made by the parent insect when the egg is deposited, that causes the exudation and subsequent concretion of the juices forming the gall.*

A few other instances of beetles producing galls are recorded by naturalists. Kirby and Spence have ascertained, for example, that the bumps formed on the roots of kedlock or charlock (Sinapis arvensis) are inhabited by the larvæ of a weevil (Curculio contractus, Marsham; and Rhynchœnus assimilis, $\mathrm{F}_{\mathrm{ABR}}$ ); and it may be reasonably supposed that either the same or similar insects cause the clubbing

$$
\text { * J. R. }
$$

YOL. IV. 
of the roots of cabbages, and the knob-like galls on turnips, called in some places the anbury. They are evidently beetles of an allied genus which form the woody galls sometimes met with on the leaves of the guelder-rose (Viburnum), the lime-tree (Tilia europaa), and the beech (Fagus sylvatica).

There are also some two-winged flies which produce woody galls on various plants, such as the

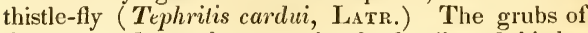
this pretty fly produce on the leaf-stalks of thistles an oblong woody knob. On the common white briony (Bryonia dioica) of our hedges may be found a very pretty fly of this genus, of a yellowish brown colour, with pellucid wings, waved much like those of the thistle-fly with a yellowish brown. This fly lays its eggs near a joint of the stem, and the grubs live upon its substance. The joint swells out into an oval form, furrowed in several places, and the fly is subsequently disclosed. In its perfect state, it ieeds on the blossom of the briony.* Flies of another minute family, the gall-gnats (Cecidomyice, LATr.), pass the first stage of their existence in the small globular cottony galls which abound on germander speedwell (Veronica chamadrys), wild thyme (Thymus serpyllum), and ground ivy (Glechoma liederacea). The latter is by no means uncommon, and may be readily recognised.

Certain species of plant-lice (Aphydes), whose complete history would require a volume, produce excrescences upon plants which may with some propriety be termed galls, or semi-galls. Some of these are without any aperture, whilst others are in form of an inflated vesicle, with a narrow opening on the under side of a leaf, and expanding (for the most part irregularly) into a rounded knob on its upper 
surface. The mountain-ash (Pyrus aucuparia) has its leaves and young shoots frequently affected in this way, and sometimes exhibits galls larger than a walnut, or even than a man's fist: at other times they do not grow larger than a filbert. Upon opening one of these, they are found to be filled with the aphides sorbi. If taken at an early stage of their growth, they are found open on the under side of the leaf, and inhabited only by a single female aphis, pregnant with a numerous family of young. In a short time, the aperture becomes closed, in consequence of the insect making repeated punctures round its edge, from which sap is exuded, and forms an additional portion of the walls of the cell.

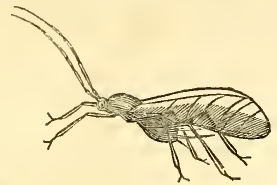

A Plant Louse (Aphis), magnified.

In this early stage of its growth, however, the gall does not, like the galls of the cynips, increase very much in dimensions. It is after the increase of the inhabitants by the young brood that it grows with considerable rapidity; for each additional insect in order to procure food, has to puncture the wall of the chamber and suck the juices, and from the punctures thus made the sap exudes, and enlarges the walls. As those galls are closed all round in the more advanced state, it does not appear how the insects can ever effect an exit from their imprisonment.

A much more common production, allied to the 
one just described, may be found on the poplar, in June and July. Most of our readers may have observed, about Midsummer, a small snow-white tuft of downy-looking substance floating about on the wind, as if animated. Those tufts of snow-white down are never seen in numbers at the same time, but generally single, though some dozens of them may be observed in the course of one day. This singular object is a four-winged fly (Eriosoma populi, LEACH), whose body is thickly covered with long down,-a covering which seems to impede its flight, and make it appear more like an inanimate substance floating about on the wind, than impelled by the volition of a living animal. This pretty fly feeds upon the fresh juices of the black poplar, preferring that of the leaves and leaf-stalks, which it punctures for this purpose with its bcak. It fixes itself with this design to a suitable place upon the principal nervure of the leaf, or upon the leaf-stalk, and remains in the same spot till the sap, exuding through the punctures, and thickening by contact with the air, surrounds it with a thick fleshy wall of living vegetable substance, intermediate in texture between the wood and the leaf, being softer than the former and harder than the latter. In this snug little chamber, secure from the intrusion of lady-birds and the grubs of aphidivorous flies ( $\left.S y y_{h} h i\right)$, she brings forth her numerous brood of young ones, who immediately assist in enlarging the extent of their dwelling, by puncturing the walls. In one respect, however, the galls thus formed differ from those of the mountain-ash just described,- these of the poplar having always an opening left into some part of the cell, and usually in that portion of it which is elongated into an obtuse beak. From this opening the young, when arrived at the winged state, make their exit, to form 
new colonies; and during their migrations, attract the attention of the most incurious by the singularity of their appearance.*

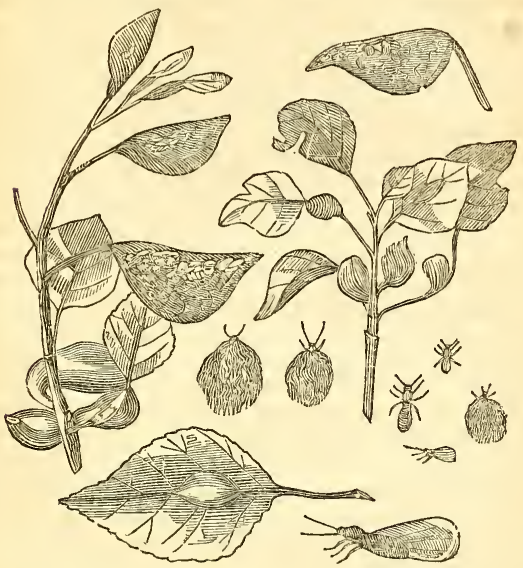

Galls produced on the letwes and leaf-stalls of the Poplar by Eriosoma populi, with the various forms of the insects, winged, not winged, and covered with wool.

On the black poplar there may be found, later in the season than the preceding, a gall of a very different form, though, like the other, it is for the most part on the leaf-stalk. The latter sort of galls are of a spiral form; and though they are closed, they open upon slight pressure, and appear to be formed of two laminæ, twisted so as to unite. It is at this 
opening that an aperture is formed spontaneously for the exit of the insects, when arrived at a perfect state. In galls of this kind we find aphides, but of a different species from the lanigerous ones, which form the horn-shaped galls above described.

\section{Lenf-Rolling Aphides.}

It may not be improper to introduce here a brief sketch of some other effects, of a somewhat similar kind, produced on leaves by other species of the same family (Aphidee). In all the instances of this kind which we have examined, the form which the leaf takes serve as a protection to the insects, both from the weather and from depredators. That there is design in it appears from the circumstance of the aphides crowding into the embowering vault which they have formed; and we are not quite certain whether they do not puncture certain parts of the leaf for the very purpose of making it arch over them; at least in many cases, such as that of the hop-fly (Aphis humuli), though the insects are in countless numbers no arching of the leaves follows. The rose-plant louse, again, (Aphis rosce,) sometimes arches the leaves, but more frequently gets under the protecting folds of the half-expanded leaf buds.*

One of the most conmon instances of what we mean occurs on the leaves of the currant-bush, which may often be observed raised up into irregular bulgings, of a reddish-brown colour. On examining the under side of such a leaf, there will be seen a crowd of small insects, some with and some without wings, which are the Aphides ribis in their diflerent stages, feeding securely and socially on the juices of the leaf.

The most remarkable instance of this, however, 


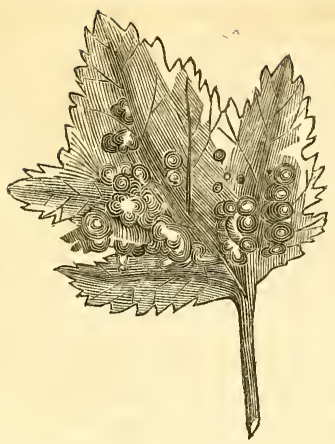

Lcaf of the Currant-bush, bulged out by the Aphis ribes.

which we have seen, occurs on the leaves of the elm, and is caused by the Aphis ulmi. The edge of an elm-leaf inhabited by those aphides is rolled up in an elegant convoluted form, very much like a spiral shell; and in the embowered chamber thus formed, the insects are secure from rain, wind, and, partially, from the depredations of carnivorous insects. One of their greatest enemies, the lady-bird (Coccinella), seldom ventures, as we have remarked into concealed corners, except in cold weather, and contrives to find food enough among the aphides which feed openly and unprotected, such as the magpie aphides of the alder (Aphides sambuci). The grubs, however, of the lady-bird, and also those of the aphidivorous flies, ( $\boldsymbol{S}_{y r} \mathrm{p} \mathrm{hi}$ ), may be found prying into the most secret recesses of a leaf, to prey upon the inna- 
bitants, whose slow movements disqualify them from effecting an escape.*

The effects of the puncture of aphides on growing plants is strikingly illustrated in the shoots of the lime-tree and several other plants, which become bent and contorted on the side, attaciked by the insects, in the same way as the shoot might warp by the loss of its juices on the side exposed to a brisk fire. The curvings thus effected become very advantageous to the insects, for the leaves sprouting from the twig, which naturally grow at a distance from each other, are brought close together in a bunch, forming a kind of nosegay, that conceals all the contour of the sprig, as well as the insects which are embowered under it, protecting them against the rain and the sun, and at the same time hiding them from observation. It is only requisite, however,

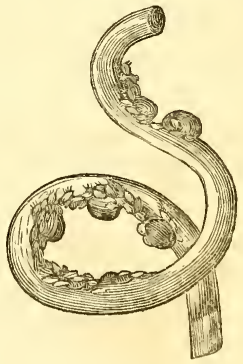

Shoot of the Lime-trec contorted by the punctures of the Aphis Tilia.

where they have formed bowers of this description, to raise the leaves in order to see the little colony of the aphides, - or the remains of those * J. R. 
habitations which they have abandoned. We have sometimes observed sprigs of the lime-tree, of a thumb's thickness, portions of which resembled spiral screws, but we could not certainly have assigned the true cause for this twisting, had we not been acquainted with the manner in which aphides contort the young shoots of this tree.* The shoots of the gooseberry and the willow are sometimes contorted in the same way, but not so strikingly as the shoots of the lime.

\section{Pseudo-Galls.}

It may not be out of place to mention here certain anomalous excrescences upon trees and other plants, which, though they much resemble galls, are not so distinctly traceable to the operations of any insect. In our researches after galls, we have not unfrequently met with excrescences which so very much resemble them, that before dissection we should not liesitate to

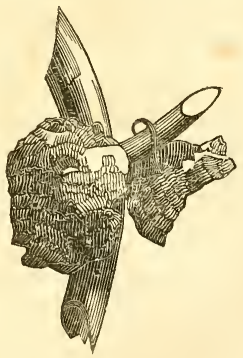

Pseudo-gall of the Bramble, drawn from a specimen.

* Réaumur, vol. iii.

VOL. IV. 
consider them as such, and predict that they formed the nidus of some species of insects. In more instances than one we have felt so strongly assured of this, that we have kept several specimens for some months, in nurse-boxes, expecting that in due time the perfect insects would be disclosed.

One of these pseudo-galls occurs on the common bramble (Rubus fruticosus), and bears some resemblance to the bedeguar of the rose when old and changed by weather. It clusters round the branches in the form of irregular granules, about the size of a pea, very much crowded, the whole excrescence being rather larger than a walnut. We expected to find this excrescence full of grubs, and were much surprised to discover, upon dissection, that it was only a diseased growth of the plant, caused (it might be) by the puncture of an insect, but not for the purpose of a nidus or habitation.

Another sort of excrescence is not uncommon on the terminal shoots of the hawthorn. This is in general irregularly oblong, and the bark which covers it is of an iron colour, similar to the scoriæ of a blacksmith's forge. When dissected, we find no traces of insects, but a hard, ligneous, and rather porous texture. It is not improbable that this excrescence may originate in the natural growth of a shoot being checked by the punctures of aphides, or of those grubs which we have described (page 389).

Many of those excrescences, however, are probably altogether unconnected with insects, and are simply hypertrophic diseases, produced by too much nourishment, like the wens produced on animals. Instances of this may be seen at the roots of the holyhock (Allhea rosea) of three or four years' standing; on the stems of the elm and other trees, immediately

* J. R. 

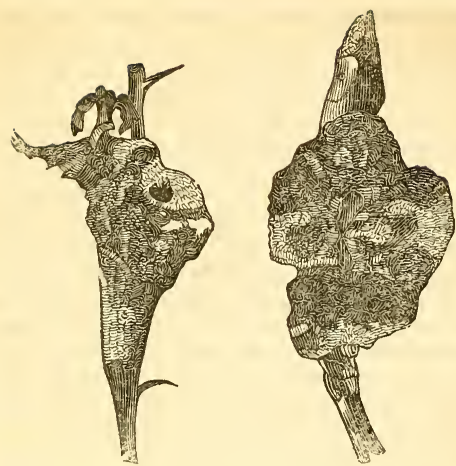

Pseuds-5alls of the Hawthorn, drawn fiom specimens.

above the root; and on the upper branches of the birch, where a crowded cluster of twigs sometimes grows, bearing no distant resemblance to a rook's nest in miniature.

One of the prettiest of those pseudo-galls with which we are acquainted, is produced on the Scotch fir (Pinus sylvestris), by the aphis pini, which is one of the largest species of our indigenous aphides. The production we allude to may be found, during the

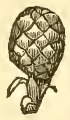

Pseudo-gall produced by Aphis Pini on the Scoteh fir, drawn from a specimen. 
summer months, on the terminal shoots of this tree, in the form of a small cone, much like the fiuit of the tree in miniature, but with this difference, that the fruit terminates in a point, whereas the pseudo-gall is nearly globular. Its colour also, instead of being green is reddish; but it exhibits the tiled scales of the fruit cone.

We have mentioned this the more willingly that it seems to confirm the theory which we hazarded above, respecting the formation of the bedeguar of the rose and other true galls-by which we ascribed to the sap diverted from its natural course by insects, a tendency to form leaves, \&c., like those of the plant from which it is made to exude. 


\section{Chapter XX.}

Animal Galls, ${ }^{*}$ produced by Breeze-Flies, and Snail-Bectles.

THE structures which we have hitherto noticed have all been formed of inanimate materials, or at the most of growing vegetables; but those to which we shall now advert are actually composed of the flesh of living animals, and seem to be somewhat akin to the galls already described, as formed upon the shoots and leaves of plants. These were first investigated by the accurate Vallisnieri, and subsequently by $\mathbf{R}$-aumur, De Geer, and Linnæus; but the best account which has hitherto been given of them is by our countryman Mr Bracey Clark, who differs essentially from his predecessors as to the mode in which the eggs are deposited. As in consequence of the extreme difficulty, if not the impossibility, of personal observation, it is no easy matter to decide between the conflicting opinions, we shall give such of the statements as appear most plausible.

The mother breeze-fly (Oestrus bovis, Clark;Hypoderma bovis, Latr.), which produces the tumours in cattle called wurbles, or wormuls (quasi, worm-holes), is a two-winged insect, smaller, but similar in appearance and colour to the carder-bee (p. 64), with two black bands, one crossing the shoulders and the other the abdomen, the rest being

* In order to prevent ambiguity, it is necessary to remark that the excrescences thus called must not be confounded with the true galls, which are occasionally found in the gall bladder. VOL. IV. 
covered with yellow hair. This fly appears to have been first discovered by Vallisnieri, who has given a curious and interesting history "of his observations upon its economy. "After having read this account," says Reaumur, "with sincere pleasure, I became cxceedingly desirous of seeing with my own eyes what the Italian naturalist had reported in so eruclite and pleasing a manner. I did not then imagine that it would ever be my lot to speak upon a subject which had been treated with so much care and elegance; but since I have enjoyed more favourable opportunities than M. Vallisnieri, it was not difficult for me to investigate some of the circumstances better, and to consider them under a different point of view. It is not indeed very wonderful to discover something new in an object, though it has been already carefully inspected with very good eyes, when we sit down to examine it more narrowly, and in a more favourable position; while it sometimes happens, also, that most indifferent ubservers have detected what had been previously unnoticed by the most skilful interpreters of nature." "*

From the obscrvations made by Réaumur, he concluded that the mother-fly, above described, deposits her eggs in the flesh of the larger animals, for which purpose she is furnished with an ovipositor of singular mechanism. We have seen that the ovipositors of the gall-flies (Cynips) are rolled up within the body of the insect somewhat like the spring of a watch, so that they can be thrust out to more than double their apparent length. 'To effect the same purpose, the ovipositor of the ox-fly lengthens, by a series of sliding tubes, precisely like an operaglass. There are four of these tubes, as may be seen by pressing the belly of the fly till they come

* Réaumur, Nem. iv. 505. 
into view. Like other ovipositors of this sort, they are composed of a horny substance; but the terminal piece is very different indeed from the same part in the gall-flies, the tree-hoppers (Cicadre), and the ichncumons, being composed of five points, three of which are longer than the other two, and at first sight not unlike a fleur-de-lys, though, upon narrower inspection, they may be discovered to terminate in curved points, somewhat like the claw of a cat. The two shorter pieces are also pointed, but not curved; and by the union of the five, a tube is composed for the passage of the eggs.

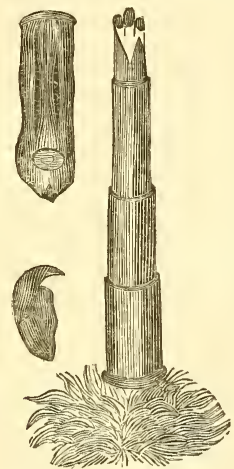

Ovipositor of the breeze-fly, greatly magnified, with a claw and part of the tube, distinct.

It would be necessary, Réaumur confesses, to see the fly employ this instrument to understand in what manner it acts, though he is disposed to consider it 
fit for boring through the hides of cattle. "Whenever I have succeeded," he adds, "in secing these insects at work, they have usually shown that they proceeded quite differently from what I had imagined; but unfortunately I have never been able to see one of them pierce the hide of a cow under my eyes."

Mr Bracey Clark, taking another view of the matter, is decidedly of opinion that the fly does not pierce the skin of cattle with its ovipositor at all, but merely glues its eggs to the hairs, while the grubs, when hatched, eat their way under the skin. If this be the fact, as is not improbable, the three curved pieces of the ovipositor, instead of acting, as Réaumur imagined, like a centre-bit, will only serve to prevent the eggs fiom falling till they are firmly glued to the hair, the opening formed by the two shorter points permitting this to be effected. This account of the matter is rendered more plausible, from Réaumur's statement that the deposition of the egg is not attended by much pain, unless, as he adds, some very sensible nervous fibres have been wounded. According to this view, we must not estimate the pain produced by the thickness of the instrument; for the sting of a wasp or a bee, although very considerably smaller than the ovipositor of the ox-fly, causes a very pungent pain. It is, in the latter case, the poison infused by the sting, rather than the wound, which occasions the pain; and Vallisnieri is of opinion that the ox-fly emits sone acrid matter along with her eggs, but there is no proof of this beyond conjecture.

It ought to be remarked, however, that cattle have very thick hides, which are so far fiom being acutely sensitive of pain, that in countries where they are put to draw ploughs and waggons, they find a whip

* Mem. iv. 538. 
ineffectual to drive them, and have to use a goad, in form of an iron needle, at the end of a stick. Were the pain inflicted by the fiy very acute, it would find it next to impossible to lay thirty or forty eggs without being killed by the strokes of the ox's tail; for though $V$ allisnieri supposes that the fly is shrewd enough to choose such places as the tail cannot reach, $R_{\text {vau- }}$ mur saw a cow repeatedly flap its tail upon a part full of the gall-bumps; and in another instance he saw a heifer beat away a party of common flies from a part where there were seven or eight gall-bumps. He concludes, therefore, with nuch plausibility, that these two beasts would have treated the ox-flies in the same way, if they had given them pain when depositing their eggs.

The extraordinary effects produced upon cattle, on the appearance of one of these flies, would certainly lead us to conclude, that the pain inflicted is excruciating. Most of our readers may recollect to have seen, in the summer months, a whole herd of cattle start off across a field in full gallop, as if they were racing,-their movements indescribably awkwardtheir tails being poked out behind them as straight and stiff as a post, and their necks stretched to their utmost length. All this consternation has been known, from the earliest times to be produced by the fly we are describing. Virgil gives a correct and lively picture of it in his Georgics,* of which the following is a translation, a little varied from Trapp:-

Round mount Alburnus, green with shady oaks, And in the groves of Silarus, there flies

* Est lucos Silari circa illicibusque virentem Plurimus Alburnum volitans, cui nomen asilo Romanum est, (Estrum Graii vertere vocantes, Asper, acerba, sonans; quo tota exterrita sylvis Diffugiunt armenta; furit mugitibus æther Concussus, sylvæque et sicci ripi Tanagri.

Georg. lib. III. I. 146. 
An insect pest (named Estrus by the Greeks, By us Asilus): fierce with jarring hum

It darts towards the herd, driving them terrified From glade to glade, while the far sky resounds, And woods and rivers' banks echo their lowings.

Had we not other instances to adduce, of similar terror caused among sheep, deer, and horses, by insects of the same genus, which are ascertained not to penetrate the skin, we should not have hesitated to conclude that $V$ allisnieri and $\mathbf{R}$ aumur are right, and $\mathrm{Mr}$ Bracey Clark wrong. In the strictly similar instance of Rein-deer fly (OEstrus tarandi, Lisx.), we have the high authority of Linnæus for the fact, that it lays its eggs upon the skin.

"I remarked," he says, "with astonishment how greatly the reindeer are incommoded in hot weather, insomuch that they cannot stand still a minute, no not a moment, without changing their posture, starting, puffing and blowing continually, and all on account of a little fly. Even though amongst a herd of perhaps five hundred reindeer there were not above ten of those flies, every one of the herd trembled and kept pushing its neighbour about. The fly, meanwhile, was trying every means to get at them; but it no sooner touched any part of their bodies, than they made an immediate eflort to shake it off. I caught one of these insects as it was flying along with its tail protruded, which had at its extremity a small linear orifice perfectly white. The tail itself consisted of four or five tubular joints, slipping into each other like a pocket spying-glass, which this fly, like others, has a power of contracting at pleasure." *

In another work he is still more explicit. "This well-known fly," he says, "hovers the whole day over the back of the reinceer, with its tail protruded

* Linnæus, Lachesis Lapponica, July 19 th. 
and a little bent, upon the point of which it holds a small white egg, scarcely so large as a mustard-seed, and when it has placed itself in a perpendicular position, it drops its egg, which rolls down amongst the hair to the skin, where it is hatched by the natural heat and perspiration of the reindeer, and the grub eats its way slowly under the skin, causing a bump as large as an acorn." the reindeer breeze-fly are figured in the Library of Entertaining Knould de, Menageries, Vol. 1., p. 405.

There is one circumstance which, though it appears to us to be of some importance in the question, has been either overlooked or misrepresented in books. "While the female fly," says Kirby and Spence, "is performing the operation of oviposition, the animal attempts to lash her off as it does other flies, with its tail;" $†$ though this is not only at variance with their own words in the page but one preceding, where they most accurately describe " the herd with their tails in the air, or turned upon their backs, or stiffly stretched out in the direction of the spine," but with the two facts mentioned above from Réaumur, as well as with common observation. If the ox then do not attempt to lash off the breeze-fly, but runs with its tail stiffly extended, it affords a strong presumption, that the fly terrifies him by her buzzing (asper, aeerba, sonans), rather than pains him by piercing lis hide; her buzz, like the rattle of the rattle-snake, being instinctively understood, and intended, it may be, to prevent an over population, by rendering it difficult to deposit the eggs.

The horse breeze-fly (Gasterophilus equi, $\mathrm{LEAcH}$ ), which produces the maggots well known by the name of botts in horses, is ascertained beyond a doubt to * I.innæus, Flora Lapponica. P. 378, ed. Lond. 1792.

$\uparrow$ Kirby and Spence, Introd. i. $151 . \quad+$ Ibid. p. 149. 
deposit her eggs upon the hair, and as insects of the same genus almost invariably proceed upon similar principles, however much they may vary in minute particulars, it may be inferred with justice, that the breeze-flies which produce galls, do the same. The description given by $\mathrm{Mr}$ Bracey Clark, of the proceedings of the horse breeze-fly, is exceedingly interesting.

"When the female has been impregnated, and her eggs sufficiently matured, she seeks among the horses a subject for her purpose, and approaching him on the wing, she carries her body nearly upright in the air, and her tail, which is lengthened for the purpose, , curved inwards and upwards: in this way she approaches the part where she designs to deposit the egg; and suspending herself for a few seconds before it, suddenly darts upon it and leaves the egg adhering to the hair; she hardly appears to settle, but merely touches the hair with the egg held out on the projected point of the abdomen.* The egg is made to adhere by means of a glutinous liquor secreted with it. She then leaves the horse at a small distance, and prepares a second egg, and poising herself before the part, deposits it in the same way. The liquor dries, and the egg becomes firmly glued to the hair; this is repeated by these flies till four or five hundred eggs are sometimes placed on one horse."

Mr Clark farther tells us, that the fly is careful to select a part of the skin, which the horse can easily reach with his tongue, such as the inside of the knee, or the side and back part of the shoulder. It

* These circumstances afford, we think, a complete answer to the query of Kirby and Spence,- "There can be little doubt, (or else what is the use of such an apparatus?) that it bores a hole in the skin." -Introd., i. 162, 2nd. edit. 
was at first conjectured, that the horse licks off the eggs thus deposited, and that the are by this means conveyed into its stomach; but Mr Clark says, "I do not find this to be the case, or at least only by accident; for when they have remained on the hair four or five days, they become ripe, after which time the slightest application of warmth and moisture is sufficient to bring forth, in an instant, the latent larva. At this time, if the tongue of the horse touches the egg, its operculum is thrown open, and a small, active worm is produced, which readily adheres to the moist surface of the tongue, and is thence conveyed with the food to the stomach." He adds, that "a horse which has no ova deposited on him may yet have botts, by performing the friendly office of licking another horse that has." "The irritations produced by common flies (Anthomyice meteorica, MeIgen), are alleged as the incitement to licking.

The circumstance, however, of most importance to our purpose, is the agitation and terror produced both by this fly, and by another horse breeze-fly (Gasterophilus homorhoidalis, Lеaсн), which deposits its eggs upon the lips of the horse, as the sheep-breeze fly (Estrus ovis) does on that of the sheep. The first of these is described by Mr Clark as " very distressing to the animal, from the excessive titillation it occasions; for he immediately after rubs his mouth against the ground, his fore-feet, or sometimes against a tree, with great emotion; till finding this mode of defence insufficient, he quits the spot in a rage, and endeavours to avoid it by galloping away to a distant part of the field, and if the fly still continues to follow and teaze him, his last resource is in the water, where the insect is never observed to pur-

* Linn. Trans. iii. 305.

vol. IV. 
sue him. These flies appear sometimes to bide themselves in the grass, and as the horse stoops to graze they dart upon the mouth or lips, and are always observed to poise themselves during a few seconds in the air, while the egg is preparing on the extended point of the abdomen."

The moment the second fiy just mentioned touches the nose of a sheep, the animal shakes its head and strikes the ground violently with its fore-feet, and at the same time holding its nose to the earth, it runs away looking about on every side to see if the flies pursue. A sheep will also smell the grass as it goes, lest a fly should be lying in wait, and if one be detected, it runs off in terror. As it will not, like a horse or an ox, take refuge in the water, it has recourse to a rut or dry dusty road, holding its nose close to the ground, thus rendering it dificult for the fly to get at the nostril.

When the egg of the ox-ireeze fly (Hypoderma
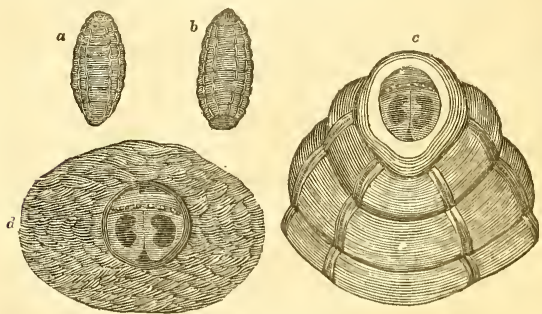

a The belly of the grub. $b$ lts back. $c$ The tail of the grub, greatly magnified. ¿ The bump, or gall, having its external aperture filled with the tail of the grub.

* Linn. Trans, iii. 305. 
bovis, LATR.) is hatched, it immediately (if $\mathrm{Mr}$ Bracey Clark be correct) burrows into the skin; while, according to $\mathbf{R}$.aumur, it is hatched there. At all events, the grub is found in a bump on the animal's back, resembling a gall on a tree,- " a place," says R aumur, "where food is found in abundance, where it is protected fiom the weather, where it enjoys at all times an equal degree of warmth, and where it finally attains maturity." When in an advanced stage, the bumps appear much like the swellings produced upon the forehead by a smart blow. These, with the grubs, are represented in the foregoing figure, and also at page 412 .

Every bump, according to $R^{\text {-aumur, has in its }}$ inside a cavity, which is a lodging proportionate to the size of the insect. The bump and cavity also increase in proportion to the growth of the grub. It is not until about the middle of May that these bumps can be seen full grown. Owing to particular circumstances, they do not all attain an equal size. The largest of them are sixteen or seventeen lines in diameter at their base, and about an inch high; but they

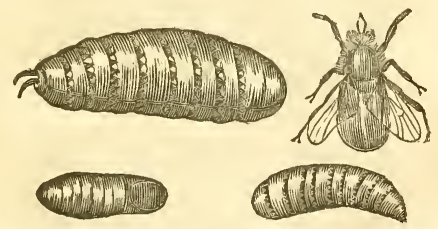
Fly, maggot, and grub of the ox-breeze, with a microscopic view of the
maggot.

* Mom. iv, 540 . 
are scarcely perceptible before the beginning, or during the course of the winter.

It is commonly upon young cattle, such, namely, as are two or three years old, that the greatest number of bumps is found; it being rare to observe them upon very old animals. The fly seems to be well aware that such skins will not oppose too much resistance, and seems to know, also, that tender flesh is the most proper for supplying good nourishment to its progeny. "And why," asks $\mathbf{R}$ aumur, "should not the instinct which conducts it to confide its eggs to the flesh of certain species only, lead it to prefer the flesh of animals of the same species which is most preferable?" The number of bumps which are found upon a beast is equal to the number of eggs which have been deposited in its flesh; or, to speak more correctly, to the number of eggs which have succeeded, for apparently all are not fertile; but this number is very different upon different cattle. Upon
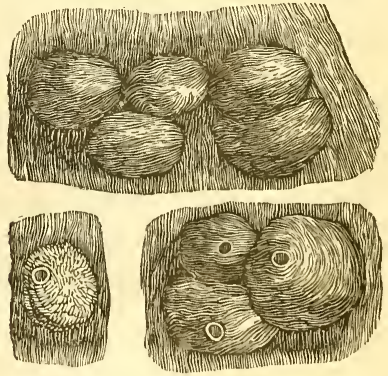

Bumps or wurbles produced on cattle by the Ox-breeze. 
one cow only three or four bumps may be observed, while upon another there will appear from thirty to forty. They are not always placed on the same parts, nor arranged in the same manner: commonly, they are near the spine, but sometimes upon or near the thighs and shoulders. Sometimes they are at remote distances from each other; at other times they are so near that their circumferences meet. In certain places, three or four tumours may be seen touching each other; and more than a dozen sometimes occur arranged as closely together as possible.

It is very essential to the grub that the hole of the tumour should remain constantly open; for by this aperture a communication with the air necessary for respiration is preserved; and the grub is thence placed in the most favourable position for receiving air. Its spiracles for respiration like those of many other grubs are situated immediately upon the posterior extremity of the body. Now, being almost always placed in such a situation as to have this part above, or upon a level with the external aperture, it is enabled to respire freely.*

We have not so many examples of galls of this kind as we have of vegetable galls; and when we described the-surprising varieties of the latter, we did not perceive that it was essential to the insects inhabiting them to preserve a communication with the external air: in the galls of trees, openings expressly designed or kept free for the admission of air are never observed. Must the grub, then, which inhabits the latter have less need of respiring air than the grub of the breeze-flies in a fresh gall? IVithout doubt, not; but the apertures by which the air is admitted to the inhabitants of the woody gall, although they may escape our notice, in consequence

* Ríaumur, iv. 549 .

VOL IV 
of their minuteness, are not, in fact, less real. We know that however careful we may be in inserting a cork into a glass, the mercury with which it is filled is not sheltered from the action of the air, which weighs upon the cork; we know that the air passes. through, and acts upon the mercury in the tube. The air can also, in the same way, penetrate through the obstruction of a gall of wood, though it have no perceptible opening or crack; but the air cannot pass in this manner so readily through the skins and membranes of animals.

In order to see the interior of the cavity of an animal gall, Réaumur opened several, either with a razor or a pair of scissors; the operation, however, cannot fail to be painful to the cow, and consequently it renders it impatient under the process. The grub being confined in a tolerably large fistulous ulcer, a part of the cavity must necessarily be filled with pus or matter. The bump is a sort of cautery, which has been opened by the insect, as issues are made by caustic: the grub occupies this issue, and prevents it from closing. If the pus or matter which is in the cavity, and that which is daily added to it, had no means of escaping, each tumour would become a considerable abscess, in which the grub would perish: but the hole of the bump, which admits the entrance of the air, permits the pus or matter to escape; that pus frequently matts the hairs together which are above the small holes, and this drying around the holes, acquires a consistency, and forms in the interior of the opening a kind of ring. This matter appears to be the only aliment allowed for the grub, for there is no appearance that it lives, like the grubs of fleshflies, upon putrescent meat. Mandibles, indeed, similar to those with which other grubs break their food, are altogether wanting. A beast which has thirty, forty, or more of these bumps upon its back, would 
be in a condition of great pain and suffering, terrible indeed in the extreme, if its flesh were torn and devoured by as many large grubs; but there is every appearance that they do not at all afflict, or only afflict it with little pain. For this reason cattle most covered with bumps are not considered by the farmer as injured by the presence of the fly, which generally selects those in the best condition.

A fly, evidently of the same family with the preceding, is described in Bruce's Travels, under the name of zimb, as burrowing during its grub state in the hides of the elephant, the rhinoceros, the camel, and cattle. "It resembles," he says, " the gad-fly in England, its motion being more sudden and rapid than that of a bee. There is something peculiar in the sound or buzzing of this insect; it is a jarring noise together with a humming, which as soon as it is heard, all the cattle. forsake their food and run wildly about the plain, till they die, worn out with fatigue, fright, and hunger. I have found," he adds, "some of these iubercles upon almost every elephant and rhinoceros that $I$ have seen, and attribute them to this cause. When the camel is attacked by this fly, his body, head, and legs, break out into large bosses, which swell, break and putrefy, to the certain destruction of the creature." die under such symptoms, we do not doubt; but we should not without more minutely accurate observation trace all this to the breeze-fly.

MM. Humboldt and Bonpland discovered, in South America, a species probably of the same genus, which attacks man himself. The perfect insect is about the size of our common house fly, (Musca domestica), and the bump formed by the grub, which is usually on the belly, is similar to that

* Bruce's Travels, i. 5, and v. 191. 
caused by the ox breeze-fly. It requires six months to come to maturity, and if it is irritated it eats deeper into the flesh, sometimes causing fatal inflammations.

\section{Grub Parasite in the Snail.}

During the summer of 1829 , we discovered in the hole of a garden-post, at Blackheath, one of the larger grey snail shells (Hèlix aspersa, Muluer), with three white soft-bodied grubs, burrowing in the body of the snail. They evidently, from their appearance, belonged to some species of beetle, and we carefully preserved them in order to watch their economy. It appeared to us that they had attacked the snail in its strong hold, while it was laid up torpid for the winter; for more than half of the body was already devoured. They constructed for themselves little cells attached to the inside of the shell and composed of a sort of fibrous matter, having no distant resemblance to shag tobacco, both in form and smell, and which could be nothing else than the remains of the snail's body. Soon after we tonk them, appearing to have devoured all that remained of the poor snail, we furnished them with another, which they devoured in the same manner. They formed a cocoon of the same fibrous materials during the autumn, and in the end of October appeared in their perfect form, turning out to be the Dirlus flavescens the grub of which was first discovered in France in 1824. The time of their appcarance, it may be remarked, coincides with the period when snails become torpid.* 
ThE subject of Insect Architecture, to which this volume is devoted, forms only one division, though a most interesting and important one, of that branch of natural history which relates to insects. It presents some of the most striking views of their economy; and, as we have endeavoured to render the examples of extraordinary instinct with which it abounds obvious and familiar to every reader, it precedes somewhat naturally a more minute account of the physiological part of the science of Entomology, and of the benefits and injuries produced to man by insects, in the respective stages of their existence. The present volume is complete in itself; and we hope that few will peruse it without having their attention awakened, and their curiosity gratified. It is intended, however, to follow it up by a second volume, to be entitled Insect Transformations. The same mode of illustration will be adopted in this projected work as in the present volume; and it is expected that the two will form a tolerably complete view, for all popular objects, of the Natural History of Insects. 
1 Eggs of Insects, magnified Page

2 Larvæ, Grubs, Caterpillars, or Maggots ' • . . 20

3 Pupæ, or Chrysalides . . . . . . . 21

4 Insects in the imago or perfect state . . . . 22

5 Mason-wasp . . . . . 26

6 Jaws of nuason-wasp, magnified . . . . . 27

7 Cuckoo-fly . . . . . 29

8 Mason-wasp's nest and cocoons . . . . . ib.

9 Mason-wasp . . . . . . ib.

10 Nesis, \&c. of mason-wasps . . . . . . 31

1 Mason-bee . . . . . . . 34

12 Exterior wall of mason bee's nest . . . + . ib.

13 Cells of mason-bee's nest . . . . . 35

14 Varipties in cells of mason-bee's nests, three figures . . 41

15 Mason-bee arid nest . . . . . 43

16 Cell of mining-hee . . . . . . . ib.

17 Nests of carpenter-bees, four figures . . . . 49

18 Carpenter bee. . . . . ib.

19 Teetls of carpenter-bee, maguified . . . . ib.

20 Nests of carpenter-wasps, two figures . . . . 53

21 Carpenter wasp . . . . . . ib.

22 Cocoon of a Carpenter-rsasp . . . . . ib.

23 Rose-leaf-cutter-hees, and nest lined with rose-leaves 61

24 Carder-bres heckling inoss for their nests . . . . 66

25 Exterior of the carder bee's nest . . . . . ib.

26 Breeding cells of the carder-bee . . . . . 68

27 Interior of carder bee's nest, two figures . . . 69

28 Section of social-wasp's nest . . . . . . 76

29 Suspenition rod of sucial-wasp's nest $\quad$ - . . 77

30 Portion of external crust of sccial-wasp's nest . . . ib.

31 Hornet's nest in its first stage . . . . . 80

32 Singnlar wisp's nest $. \quad . \quad$. . . . 82

33 W'asp's cells attaclird to a branch . . . . . 83

34 Nest of the card-maker-wasp . . . . . . 88

35 Part of a honeycomb and bees at work . . . 89

36 Worker-bee, nagnified . . . . . . 103

37 Ahilomen of wax-working bee . . . . . 104

38 Siructure of the legs of the bee for carrying propolis, \&c. 110

39 Curlain of wax-workers, secreting wax . . . 1/4

40 Wax-worker laying the fcundation of the first cell . $\quad 117$

41 Curtain of wax workers . . . . . . . 119

42 Arrangement of cells of hive hees . . . . 122

43 Foumdation-wall enlarged and the cells cominenced . 125

44 Ovipositors, with files, of the tree-hopper, maguified • 150

45 Excavations for eggs of tree-hopper, with lid raised . 151

46 Ovipositor of saw-fly protruded from its slseath, magnified 153

47 Ovipositor saw of saw-fly, magnified . . • . 154

48 Portion of saw-fly's comb-toothed rasp, and saw _ . 156

49 Nest of eggs of saw-fly . . . . . . . 158

50 Lilac-tree moth . . . . . . . . 160

51 Nest of a lilac-leaf-roller . . . . . . 161

52 Another nest of lilac-leaf-roller . . . . . 162

53 Sinall g reen oak-moth . . . . . - ib. 
54 Nests of oak-leaf-rolling caterpillar $\quad$. 163

55 Nests of the nettle-leaf-rolling caterpillars . . . 165

56 Leaf-rolling caterpillars of the sorrel . . . 168

57 Nests of the hesperia malva, with caterpillar, chrysalis, \&c. 169

58 Nest of willow-leaf-roller . . 170

59 Ziczac caterpillar and nest . . . . . . 172

60 Cypress-purge caterpillars . . . . . 179

61 Cocoon of ditto on a branch . . . . . $i b$.

62 Sinall caterpillar and moss cell of the same $\quad . \quad . \quad 183$

63 Leaf nest of the caddis-worm . . . . . 185

64 Reed nest of ditto . . . . . ib.

65 Aquatic nost of ditto . . . . . . 186

66 Shell uest of ditto, five figures . . . . . $i b$.

67 Stone nest of ditto . . . . . 187

68 Sand nest of ditto, balanced with a stone _. . . . ib.

69 Nest of ditto, balanced with straws . . . 188

70 Caterpillar of goat-moth in a willow tree . . . 189

71 Winter nest of the goat-caterpillar . . . . 190

72 Nest of goat-morb, raised to shew the pupa . 151

73 Eggs of the fuss-moth . . . . . 102

74 Rudimenis of the cell of the puss-moth . 194

75 Cell built by the larva of the puss-moth . . . 1:5

76 Ichneumon . . . . . . . $\quad$. $b$.

77 Magnitied cells of Pyralis strigulalis . . . . $\quad 198$

78 Nests of earth-mason caterpillars, two figures _. . 201

79 Earth-mason caterpillars' nests, caterpillar and moth 202

80 Earth-mason caterpillars' nests, moth, \&c. seven figures . 205

81 Nests of the grubs of ephemera, two figures . . 206

82 Grub of ephemera . . . . . $i b$.

83 Nests of epliemera in holes of cossus . . . 207

84 Grub of the ant-liou, maznified . . . . . 211

85 Trap of the ant-lion in different stages, two figures . ib.

86 Ant-lion' pitfalls iu an experimenting box . . . 212

87 Cases, sc. of the elothes-moth, and perfect motis . 2:1

83 Caterpillar's teat upon the leaf of an $\mathrm{tm}$. . . 224

89 Tents of the caterpillar in different stages . . . 226

90 Tents and caterpillars, natural size, and magnified . 228

91 Branch of the willow with seed spikes . . . 2:2

92 Muff tents made of the above cotion . . . . it.

93 Muff making caterpillar . . . . . . ib.

94 Leaf of the montilly rose mined by caterpillars . . 234

95 Leaf of the dew-nerry bramble mined . . . 23 j

96 Leaf of the primrose mined . . . . . 237

97 Capricorn beetle rounding off tlie bark of a tree . $\quad 210$

98 Mole cricket, with outline of one of its hands . . 243

99 Nest of the mole-cricket . . . . . . 244

100 Acrida verrucivora depositing her egogs . . . . . 246

101 Artificial hive for observing the mason-ants . $\quad 269$

102 Vertical section of mason-ant's nest $\quad$. . $\quad 270$

103 Contrivance of mason-ants to strengthen the building of

their nest . . . . . . . 271

104 Artificial hive for the wood-ant . . . . 276

105 Portion of a tree, with chambers, \&c., chiselled out by jet-ants 281

$106 \mathrm{~W}$ arrior-ant in the winged state . . . . . 291

107 White ant queen disteaded with eggs . . . . $\quad$ 295 
109

Covered-way and nest of the termiles arborum

110 Section of the liill-nest of the termites bellicosi

111 Hill-nest of the termites bellicosi

11. Turret-uests of white-ants . .301

113 l.eg and pro-leg of a caterpillar, greatly magnified . 307

113 Caterpiltar of the gnat-moth

114 Interior structure of the cossus . . . . . 309

115 Side view of the silk tube . . . . . . S10

116 Section of silk tuhe magnified . . . . . . ib.

117 Labiun or lower lip of cossus . . . . . 311

118 Cocoons of the emperor math . . . . . 321

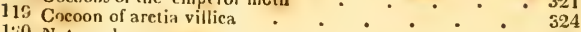

1:0 Net-work cocoon . . . . . . ib.

121 Nest of puss-moth, inciosing five cocoons . . . $326^{\circ}$

122 Winter nest of the social caterpillars of the brown-tail moth 330

123 Winter nests of P'orthesia chrysorrlæa . • . 331

124 Pendulous leaf nests • • • • • • . 332

125 Nest and order of marching of the processionary caterpillars 334

126 Garden spider suspended hy a thread from its spinneret . 336

127 Spinneret of a spider magnified to show the spinnerules 337

128 Single thread of a spider greatly magnified . • . 339

129 Attached end of a spider's thread magnified - . $3: 39$

130 Geotnetric net of the garden-spider . . . . 359

$13 t$ Nests of the mason-spider . . . . : 362

1:32 The spider, mygale cæmentaria . . . . . $i b$.

13.3 The eyes, magnified . . . . . . . $i b$.

134 Parts of the font and claw, inagnified . . . . ib.

135 Tripple-clawed foot of a spider, magnified . . . 367

136 Small berry-shaped galls of the oak leaf . . 370

137 Ovipnsitor of gall-fy, greatly magnified . . • 372

138 Gall-fly, and mechanism of nvipositor, greatly magnifed - 373

139 Bedeguar gall of the rose produced by Cynips rosæ - 376

140 One of the bristles of the hedeguar of the rose magnified 377

14l Artichnke gall of the oak-bud, with gall-lly $\quad$. 378

142. Lealy gall of dyer's broom . . . . . 380

143 semi-gall of the hawthorn . . . . . 382

144 W nolly gall of the oak . . . . . . . 383

145. Oak-apple galls, nne cut open to shew the vessels ${ }^{\circ} \cdot 384$

146 Root-galls of the oak . . . . . 385

147 Woody-galls on a willow branch . . . . 386

I48 Currant-gall of the catkins of the oak . . . . 337

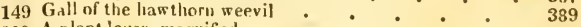

150 A plant louse, magnified . • • . . 391

151 Galls produced on the leaves of the poplar, with the various forms of the insect, ten figures

152 Luaf of the currant-bush, bulged out hy the Aphis ribes . 395

153 shont of the lime-tree contorted by the Aphis tiliz . $39: 5$

154 Psendu-gall of the bramble $. \quad . \quad 397$

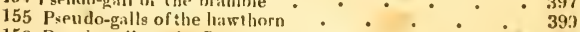

156 Pseurlo-gall on the Scotch fir . . . .

157 Ovipositor of the breeze-fly . . . . . 403

$158 \mathrm{Gruh}$ of the breeze fly, four figures $\quad . \quad 410$

159 Fly, maggnt, and grub of the ox breeze-fly . . 41

160 Buinps or wurbles produced on cat le . . . 412 




